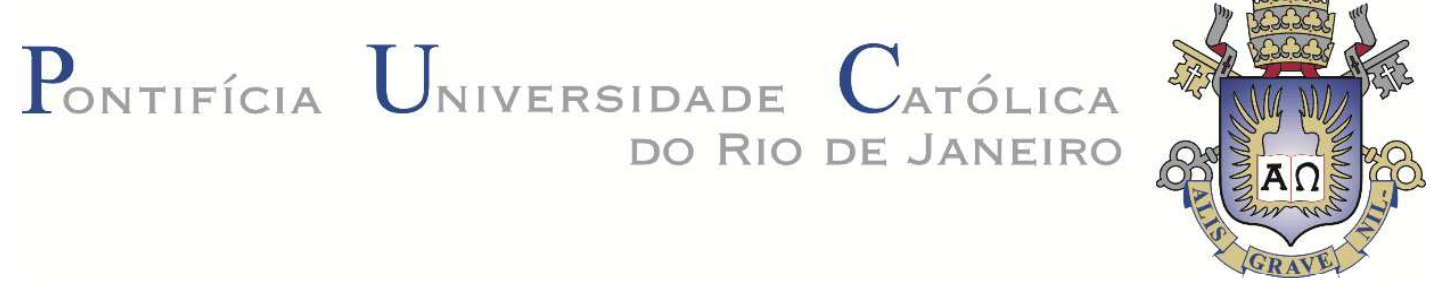

Rodrigo de Lima Rodrigues

\title{
Comportamento da Barragem de Terra da Margem Esquerda de Itaipu Durante Período de Operação
}

\section{Dissertação de Mestrado}

Dissertação apresentada ao Programa de Pós-graduação em Engenharia Civil da PUC-Rio como requisito parcial para obtenção do grau de Mestre em Engenharia Civil.

Orientador: Prof. Alberto Sampaio Ferraz Jardim Sayão Coorientadora: Enga ${ }^{a}$. Josiele Patias 
Rodrigo de Lima Rodrigues

\section{Comportamento da Barragem de Terra da Margem Esquerda de Itaipu Durante Período de Operação}

Dissertação apresentada como requisito parcial para obtenção do grau de Mestre pelo Programa de Pósgraduação em Engenharia Civil da PUC-Rio. Aprovada pela Comissão Examinadora abaixo assinada.

Prof. Alberto Sampaio Ferraz Jardim Sayão

Orientador

Departamento de Engenharia Civil e Ambiental - PUC-Rio

Eng ${ }^{\text {a }}$ Josiele Patias

Coorientadora Itaipu Binacional

Profa. Anna Laura Lopes da Silva Nunes

Universidade Federal do Rio de Janeiro - COPPE/UFRJ

Prof. Pedricto Rocha Filho Departamento de Engenharia Civil e Ambiental - PUC-Rio

Prof. Marcio da Silveira Carvalho Coordenador Setorial do Centro Técnico Cientifico - PUC-Rio

Rio de Janeiro, 22 de setembro de 2017. 
Todos os direitos reservados. É proibida a reprodução total ou parcial do trabalho sem autorização do autor, da orientadora e da universidade.

\section{Rodrigo de Lima Rodrigues}

Graduou-se em Engenharia Civil pelo Centro Universitário Dinâmica das Cataratas (UDC) em Foz do Iguaçu, Paraná em dezembro de 2014. Ingressou no mestrado na Pontifícia Universidade Católica do Rio de Janeiro em agosto de 2015, desenvolvendo dissertação na linha de pesquisa de Geotecnia Experimental aplicada à Barragens.

Ficha Catalográfica

Rodrigues, Rodrigo de Lima

Comportamento da barragem de terra da margem esquerda de Itaipu durante período de operação / Rodrigo de Lima Rodrigues ; orientador: Alberto Sampaio Ferraz Jardim Sayão ; co-orientadora: Josiele Patias. - 2017.

170 f. : il. color. ; $30 \mathrm{~cm}$

Dissertação (mestrado)-Pontifícia Universidade Católica do Rio de Janeiro, Departamento de Engenharia Civil, 2017.

Inclui bibliografia

1. Engenharia civil - Teses. 2. Itaipu. 3. Deformabilidade. 4. Barragem de terra. I. Sayão, Alberto Sampaio Ferraz Jardim. II. Patias, Josiele. III. Pontifícia Universidade Católica do Rio de Janeiro. Departamento de Engenharia Civil. IV. Título.

CDD: 624 
Ao meu pai Josue, minha mãe Ester e minha irmã Michelle. 


\section{Agradecimentos}

Agradeço a Deus em primeiro lugar, pois me deu condições de chegar onde cheguei. Sei que todos Seus planos são perfeitos. Sem Ele eu nada seria.

Ao meu pai, minha mãe e minha irmã, que desde a primeira conversa sobre a possibilidade de cursar o mestrado no Rio de Janeiro me apoiaram e incentivaram, fazendo o possível e mais um pouco para viabilizar esse feito. Morar "fora de casa" me mostrou a amplitude da palavra família.

À minha avó Isortina e ao meu avô Manoel (in memorian) pelas orações e pela torcida. Cada telefonema me enchia de forças para seguir em frente.

Ao meu orientador Alberto Sayão que como professor, orientador e amigo, me fez crescer tecnicamente e profissionalmente. Com certeza é um grande exemplo a ser seguido e suas lições jamais serão esquecidas.

À minha orientadora Josiele Patias por depositar em mim a devida confiança e viabilizar o desenvolvimento deste mestrado em parceria com o Centro de Estudos Avançados em Segurança de Barragens (CEASB) e Itaipu Binacional. Seu papel de coorientadora foi exemplar, sempre que necessário esteve presente com sua calma para uma solução técnica ou uma palavra de apoio.

À equipe da Divisão de Engenharia Civil e Arquitetura (ENCC.DT) de Itaipu que de longa data auxilia na minha vida profissional e acadêmica. É um grande prazer estar ao lado de profissionais competentes e bem-humorados. Obrigado por tolerarem o passante.

Às amigas Andrea Vecci, Ana Carolina Campos, Luana Raquel, Mariana Bernardo e ao Jainor Huamam pelas contribuições técnicas. Exerceram verdadeiro papel de professores quando precisei.

Aos amigos da favelinha: Fernanda Bernardino, Manoela Neves, Mariana Vela, Mieka Arao, Thaís Fornazelli e a turma do café da 617. Todos são responsáveis pelo meu bem-estar no dia-a-dia na PUC, com certeza todas as contribuições técnicas, longas discussões irrelevantes, histórias cômicas e afins, ficarão guardadas na lembrança. 
Ao Alan e ao Malko, que possuem títulos de amigos, mas são considerados irmãos. Ao Alan, minha eterna gratidão pela parceria nos estudos, nas notas, nos sufocos, nas alegrias, nos treinos da academia e demais aventuras que iniciamos juntos. Ao Malko, é impressionante como nos conhecemos há tão pouco tempo, mas a semelhança em nossos passados fez nos encontrarmos no presente e parecer que crescemos juntos. São raras as pessoas com tamanha semelhança no modo de pensar, de agir, de falar, de andar, de negociar, de estudar e de viver. Isso tudo tornou a vivencia neste período muito melhor. É confortante saber que não se é anormal, que existem pessoas como eu.

À professora Michéle Casagrande, que se tornou amiga e companheira dos lanches vespertinos.

À familia Valente, que me acolheu neste período e me fez "filho mais velho".

À família Mendonça, que teve papel substancial na minha vida pessoal e espiritual.

A todos amigos que fiz no Rio de Janeiro, pois de forma direta ou indireta participaram desta dissertação.

À PUC-Rio - Pontificia Universidade Católica do Rio de Janeiro e ao Departamento de Engenharia Civil e Ambiental, pela bolsa de isenção de taxas escolares e a oportunidade de cursar o Mestrado em uma das mais renomadas instituições do país.

À Fundação Parque Tecnológico Itaipu - FPTI-BR pelo apoio financeiro e infraestrutura disponibilizada que foi fundamental para desenvolvimento do trabalho. À equipe do CEASB, em especial à Débora, Alexandra e Dimilson que deram todo o suporte necessário no decorrer do trabalho. 


\section{Resumo}

Rodrigues, Rodrigo de Lima; Sayão, Alberto de Sampaio Ferraz Jardim (Orientador); Patias, Josiele (Coorientadora). Comportamento da Barragem de Terra da Margem Esquerda de Itaipu Durante Período de Operação. Rio de Janeiro, 2017. 170 p. Dissertação de Mestrado. Departamento de Engenharia Civil e Ambiental, Pontifícia Universidade Católica do Rio de Janeiro.

Itaipu Binacional é uma usina hidrelétrica localizada no Rio Paraná, entre Brasil e Paraguai. A barragem que forma o reservatório é composta por estruturas de concreto, enrocamento e terra. Após o enchimento do reservatório, em 1984, o nível do lago se manteve com variação média de 1,5 m, entre as cotas $219 \mathrm{~m}$ e 220,5 $\mathrm{m}$, cotas de operação da usina, apenas em poucas ocasiões foi reduzido abaixo da cota 219 m. Entre os anos de 2012 e 2015, devido à crise hídrica no sudeste do país, Itaipu passou a operar de maneira atípica a fim de suprir a queda na produção energética de outras usinas, isso fez com que a variação do nível do reservatório aumentasse para $4 \mathrm{~m}$ e permanecesse mais tempo em cotas abaixo do nível normal. Nesse mesmo período a instrumentação apontou um recalque de aproximadamente $5 \mathrm{~cm}$ em um trecho da Barragem de Terra da Margem Esquerda (BTME). Esse recalque está abaixo dos limites previstos, porém foi considerado atípico já que, desde a construção, os recalques medidos variam de 1 a $2 \mathrm{~cm}$. Neste trabalho foram realizadas simulações para análises de fluxo, estabilidade e recalques no referido trecho, considerando a variação do nível do reservatório no período atípico. As análises permitiram observar o comportamento das poropressões no maciço compactado e fundação, determinar os fatores de segurança críticos para o período nos taludes de montante e jusante e em que momento eles acontecem. As simulações também mostraram que o recalque detectado pela instrumentação não é atribuído ao adensamento primário devido à variação do nível do reservatório.

\section{Palavras-chave}

ITAIPU; deformabilidade; barragem de terra 


\section{Abstract}

Rodrigues, Rodrigo de Lima; Sayão, Alberto de Sampaio Ferraz Jardim (Advisor); Patias, Josiele (Co-advisor). Behavior Of The Left Earth Dam Of Itaipu in Operation Period. Rio de Janeiro, 2017. 170 p. Dissertação de Mestrado. Departamento de Engenharia Civil e Ambiental, Pontifícia Universidade Católica do Rio de Janeiro.

Itaipu Binacional is a hydroelectric plant located on the Parana River, between Brazil and Paraguay. The dam that forms the reservoir is made up of concrete, rock and earth-filled structures. After the reservoir was filled in 1984, the level of the lake remained with an average variation of $1,5 \mathrm{~m}$, between $219 \mathrm{~m}$ and $220,5 \mathrm{~m}$ (the operating elevation of the plant). The reduction below elevation 219 $\mathrm{m}$ only happened in very few occasions. Between the years of 2012 and 2015, due to the water crisis in the southeast of the country, Itaipu began to operate in an unprecedented manner, in order to compensate for the decrease in other energy production plants. Such operation not only caused the reservoir variation level to increase to $4 \mathrm{~m}$, but also made the water level remain below the average readings. In the same period, the instrumentation indicated, in a specific region, a $5 \mathrm{~cm}$ settlement of the Left Earth Dam. This fact was considered atypical, because, since the construction, the measured recharges had varied 1 or $2 \mathrm{~cm}$ at most. In this work, flow, stability and recharge simulations were performed to analyze the abovementioned region considering the variation of the reservoir level in this uncharacteristic period. With these analyzes it was possible to observe how the pore pressures behave in the dam and foundation; what the critical safety factors for the period in the upstream and downstream slopes are; and when they occur. The simulations also showed that the settlement detected by the instrumentation isn't attributed to consolidation due to the variation of the reservoir level.

\section{Keywords}

ITAIPU; deformability; earth dam 


\section{Sumário}

1 Introdução 21

1.1 Justificativa e Objetivos 22

1.2 Estrutura da Dissertação 23

2 Revisão Bibliográfica 25

$2.1 \quad$ Análise de Fluxo 25

2.1.1 Fluxo em Barragens 28

2.1.2 Controle de Fluxo em Barragens 29

2.2 Análise de Estabilidade 30

2.2.1 Análise Determinística 31

2.2.2 Análise Probabilística 35

2.2.3 Estabilidade em Barragens 36

2.3 Análise de Recalques 39

2.3.1 Adensamento 40

2.4 Instrumentação em Barragens de Aterro 44

2.4.1 Medidores de Nível D'água 45

2.4.2 Piezômetros standpipe 46

2.4.3 Medidores de Vazão 47

2.4.4 Marcos de Referência 48

2.5 Método dos Elementos Finitos 49

$3 \quad$ Barragem de Terra da Margem Esquerda de Itaipu 51

3.1 Características Geométricas 52

3.2 Características Geotécnicas 54

3.2.1 Maciço Compactado 54

3.2.2 Fundação 58

3.2.3 Bermas, Filtros e Transições 63

3.3 Dados Hidrometeorológicos 64 
$\begin{array}{lll}\text { 3.3.1 Precipitação } & 64\end{array}$

$\begin{array}{lll}3.3 .2 & \text { Vazões } & 64\end{array}$

3.3.3 Nível do Reservatório 65

$\begin{array}{lll}3.4 & \text { Instrumentação } & 67\end{array}$

$\begin{array}{lll}3.4 .1 & \text { Piezômetros } & 67\end{array}$

$\begin{array}{ll}3.4 .2 & \text { Medidores de Nível d’água }\end{array}$

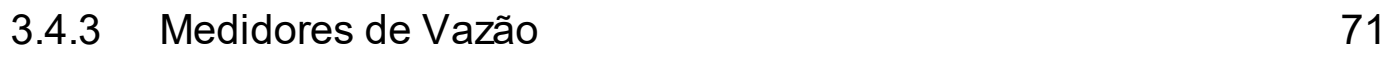

3.4.4 Medidores de Recalque $\quad 72$

3.4.5 Marcos de Referência 72

$4 \quad$ Modelagem Numérica e Resultados $\quad 74$

4.1 Modelagem das Seções $\quad 75$

$\begin{array}{lll}4.2 & \text { Análise de Fluxo } & 77\end{array}$

$\begin{array}{lll}\text { 4.2.1 Condições de Contorno } & 77\end{array}$

$\begin{array}{lll}\text { 4.2.2 } & \text { Permeabilidades } & 78\end{array}$

4.2.3 Análise do Período Proposto 80

$\begin{array}{lll}4.3 & \text { Análise de Estabilidade } & 98\end{array}$

4.3.1 Parâmetros de Resistência (c' e $\left.\Phi^{\prime}\right) \quad 99$

4.3.2 Análise Determinís tica do Período Proposto 100

$\begin{array}{lll}\text { 4.3.3 Análise Probabilística } & 108\end{array}$

$\begin{array}{lll}4.4 & \text { Análise de Recalques } & 116\end{array}$

$\begin{array}{ll}\text { 4.4.1 Condições de Contorno } & 117\end{array}$

4.4.2 Parâmetros de Deformabilidade 117

$\begin{array}{lll}\text { 4.4.3 Análise do Período Proposto } & 121\end{array}$

5 Estudos de Casos 125

5.1 Fluxo Permanente 125

$\begin{array}{lll}5.2 & \text { Rebaixamento Rápido } & 128\end{array}$

5.2.1 Seção 129+50 129

5.2.2 Seção 135+50 132

5.2.3 Seção $138+50 \quad 136$

$\begin{array}{lll}5.3 & \text { Obstruções } & 137\end{array}$ 
6 Conclusões e Sugestões para Futuros Trabalhos 140

$\begin{array}{lll}6.1 & \text { Conclusões } & 140\end{array}$

$\begin{array}{lll}6.2 & \text { Sugestões para Futuros Trabalhos } & 142\end{array}$

$\begin{array}{lll}7 & \text { Referências bibliográficas } & 143\end{array}$

$\begin{array}{lr}\text { Anexos } & 147\end{array}$

Anexo I - Regressão linear realizada nos gráficos p'x q para os ensaios UU (Q), CU (R), CUsat (Rsat) e CD (S) com amostras do $\begin{array}{ll}\text { maciço compactado. } & 148\end{array}$

Anexo II - Resultados de ensaios de adensamento realizados com $\begin{array}{ll}\text { amostras do maciço compactado. } & 153\end{array}$

Anexo III - Planta da instrumentação da BTME. 159

$\begin{array}{ll}\text { Anexo N - Plantas do sistema de drenagem superficial da BTME. } & 161\end{array}$ Anexo V - Localização dos marcos de referência na BTME. 164

$\begin{array}{ll}\text { Anexo VI- Geometria das seções estudadas. } & 167\end{array}$

$\begin{array}{ll}\text { Anexo VII - Instrumentação das seções estudadas. } & 169\end{array}$ 


\section{Lista de Figuras}

Figura 1.1 - Disposição completa da barragem de Itaipu (Adaptado de Itaipu Binacional, 2009)

Figura 1.2 - Vista geral da barragem (Adaptado de Itaipu Binacional, 2009)

Figura 2.1 - Forças entre fatias no método de Fellenius (Adaptado de Fredlund e Krahn, 1977)

Figura 2.2 - Fatia com as forças consideradas no Método de Fellenius (Duncan et al., 2014)

Figura 2.3 - Fatia com forças consideradas no Método de Bishop (Duncan et al., 2014)

Figura 2.4 - Representação das forças entre fatias no método de Spencer (Duncan et al., 2014).

Figura 2.5 - Relação entre índice de confiabilidade e probabilidade de ruptura (Sandroni e Sayão, 1992)

Figura 2.6 - Ábaco para cálculo de FS para rebaixamento rápido (adaptado de Morgenstern, 1963)

Figura 2.7 - Medidor de nível d'água (Cruz, 1996)

Figura 2.8 - Piezômetro standpipe (Cruz, 1996)

Figura 2.9 - Medidor de placa triangular (Thá, 2007)

Figura 2.10 - Tubo para medição de vazão (Thá, 2007)

Figura 3.1 - Barragem de Terra da Margem Esquerda (Itaipu Binacional)

Figura 3.2 - BTME durante construção em 1982 (adaptado de Itaipu Binacional, 2009)

Figura 3.3 - Seções típicas da BTME (Itaipu Binacional, 2009)

Figura 3.4 - Perfil geológico da região de Itaipu (Itaipu Binacional, 2009)

Figura 3.5 - Perfil típico do solo na região de Itaipu (Thá, 2007)

Figura 3.6 - Histórico de precipitações médias anuais (Itaipu Binacional)

Figura 3.7 - Vazões afluente, turbinada e vertida (Itaipu Binacional) 
Figura 3.8 - Histórico do nível do reservatório desde o enchimento (Itaipu Binacional)

Figura 3.9 - Nível do reservatório de jan/2010 a fev/2017 (Itaipu Binacional)

Figura 3.10 - Piezômetros da seção 138+50 (documento interno, SAT. 4286-DI-8125-P)

Figura 3.11 - Piezômetros da seção 129+50 (documento interno, SAT. 4286-DI-8124-P)

Figura 3.12 - Níveis do reservatório piezômetros na seção da Est. 129+50 (Itaipu Binacional)

Figura 3.13 - Medidor de nível d'água da seção 129+50 (documento interno, SAT. 4286-DI-8124-P)

Figura 3.14 - Recalques nos medidores L-19, L-20, L-21, L-22 e L-23 (Itaipu Binacional)

Figura 4.1 - Marcos de referência instalados na BTME (adaptado do Google Maps, acesso em 07/08/2017)

Figura 4.2 - Área estudada da BTME (adaptado do Google Maps, acesso em 07/08/2017)

Figura 4.3 - Seção $129+50$ modelada 76

Figura 4.4 - Seção $132+00$ modelada 76

Figura 4.5 - Seção $135+50$ modelada 76

Figura 4.6 - Seção $138+50$ modelada 76

Figura 4.7 - Seção 129+50 da BTME 81

Figura 4.8 - Malha da seção 129+50 81

Figura 4.9 - Valores de leitura do PS-L-18 e NAR 81

Figura 4.10 - Correlação dos valores lidos e simulados do PS-L-18 82 Figura 4.11 - Valores de leitura do PS-L-20 e NAR 83

Figura 4.12 - Correlação dos valores lidos e simulados do PS-L-20 83

Figura 4.13 - Fluxo através da seção 129+50 84

Figura 4.14 - Linha freática para fluxo permanente na seção 129+50 85

Figura 4.15 - Linha freática para rebaixamento rápido do NAR na seção $129+50$

Figura 4.16 - Linha freática para alteamento rápido do NAR na seção $129+50$

Figura 4.17 - Seção 132+00 da BTME 
Figura 4.18 - Malha da seção 132+00 86

Figura 4.19 - Valores de leitura do PS-L-21 e NAR 86

Figura 4.20 - Correlação dos valores lidos e simulados do PS-L-21 87

Figura 4.21 - Valores medidos do PS-L-21 e PS-L-22 88

Figura 4.22 - Valores de leitura do PS-L-22 e NAR 88

Figura 4.23 - Correlação dos valores lidos e simulados do PS-L-22 89

Figura 4.24 - Linha freática para fluxo permanente na seção 132+00 90

Figura 4.25 - Linha freática para rebaixamento rápido do NAR na seção $132+00$

Figura 4.26 - Linha freática para alteamento rápido do NAR na seção $132+00$

Figura 4.27 - Seção 135+50 da BTME (o autor) 91

Figura 4.28 - Malha da seção 135+50 91

Figura 4.29 - Valores de leitura do PS-L-23 e NAR 91

Figura 4.30 - Correlação dos valores lidos e simulados do PS-L-23 92

Figura 4.31 - Valores de leitura do PS-L-24 e NAR 92

Figura 4.32 - Correlação dos valores lidos e simulados do PS-L-24 93

Figura 4.33 - Fluxo através da seção 135+50 94

Figura 4.34 - Linha freática para fluxo permanente na seção 135+50 94

Figura 4.35 - Linha freática para rebaixamento rápido na seção 135+50 94

Figura 4.36 - Linha freática para alteamento rápido na seção 135+50 94

Figura 4.37 - Seção 138+50 da BTME 95

Figura 4.38 - Malha da seção 138+50 96

Figura 4.39 - Valores de leitura do PS-L-25 e NAR 96

Figura 4.40 - Correlação dos valores lidos e simulados do PS-L-25 96

Figura 4.41 - Valores de leitura do PS-L-26 e NAR 97

Figura 4.42 - Correlação dos valores lidos e simulados do PS-L-26 98

Figura 4.43 - Fluxo através da seção 138+50 98

Figura 4.44 - Fatores de segurança para a seção 129+50 101

Figura 4.45 - Superfície de ruptura a montante na seção 129+50 102

Figura 4.46 - Superfície de rup tura a jusante na seção 129+50 102

Figura 4.47 - Fatores de segurança para a seção 132+00 103 
Figura 4.48 - Superfície de rup tura a montante na seção 132+00 104

Figura 4.49 - Superfície de rup tura a jusante na seção 132+00 104

Figura 4.50 - Fatores de segurança para a seção 135+50 105

Figura 4.51 - Superfície de rup tura a montante na seção 135+50 105

Figura 4.52 - Superfície de ruptura a jusante na seção 135+50 106

Figura 4.53 - Fatores de segurança para a seção 138+50 107

Figura 4.54 - Superfície de ruptura a montante na seção 138+50 107

Figura 4.55 - Superfície de ruptura a jusante na seção 138+50 107

Figura 4.56 - Componentes da variância do FS na seção 129+50 111

Figura 4.57 - Componentes da variância do FS na seção 132+00 112

Figura 4.58 - Componentes da variância do FS na seção 135+50 114

Figura 4.59 - Componentes da variância do FS na seção 138+50 116

Figura 4.60 - Tensões verticais in-situ na seção 129+50 117

Figura 4.61 - Histograma do E50 do maciço compactado 118

Figura 4.62 - Histograma do E50 da fundação 119

Figura 4.63 - Histograma do coeficiente de Poisson para o maciço compactado 119

Figura 4.64 - Histograma do coeficiente de Poisson para a fundação 120

Figura 4.65 - Deslocamento vertical na crista da seção 129+50 121

Figura 4.66 - Deslocamento vertical na crista da seção 132+00 122

Figura 4.67 - Deslocamento vertical na seção 135+50 122

Figura 4.68 - Deslocamento vertical na crista da seção 138+50 123

Figura 5.1 - Fatores de segurança para seção 129+50 126

Figura 5.2 - Fatores de segurança para seção 135+50 126

Figura 5.3 - Fatores de segurança para seção 138+50 127

Figura 5.4 - Caso 1 / Fator de segurança para rebaixamento completo da seção $129+50$

Figura 5.5 - Caso 1 / Linha freática para menor FS durante rebaixamento completo da seção $129+50$

Figura 5.6 - Caso 2 / Fator de segurança para rebaixamento parcial da seção $129+50$

Figura 5.7 - Caso 2 / Linha freática para menor FS durante rebaixamento parcial da seção $129+50$ 
Figura 5.8 - Caso 3 / Fator de segurança para rebaixamento parcial da seção $129+50$

Figura 5.9 - Caso 3 / Linha freática para menor FS durante rebaixamento parcial da seção 129+50

Figura 5.10 - Caso 4 / Fator de segurança para rebaixamento completo da seção $129+50$

Figura 5.11 - Caso 4 / Linha freática para menor FS durante rebaixamento completo da seção $129+50$

Figura 5.12 - Fator de segurança para rebaixamento completo da seção $135+50$

Figura 5.13 - Caso 1 / Linha freática para menor FS durante rebaixamento completo da seção $135+50$

Figura 5.14 - Caso 2 / Fator de segurança para rebaixamento parcial da seção $135+50$

Figura 5.15 - Caso 2 / Linha freática para menor FS durante rebaixamento parcial da seção $135+50$

Figura 5.16 - Caso 3 / Fator de segurança para rebaixamento parcial da seção $135+50$

Figura 5.17 - Caso 3 / Linha freática para menor FS durante rebaixamento parcial da seção $135+50$

Figura 5.18 - Caso 4 / Fator de segurança para rebaixamento completo da seção $135+50$

Figura 5.19 - Caso 4 / Linha freática para menor FS durante rebaixamento rápido da seção $135+50$

Figura 5.20 - Caso 1 / Fator de segurança para rebaixamento completo da seção $138+50$

Figura 5.21 - Caso 1 / Linha freática para menor FS durante rebaixamento completo da seção $138+50$

Figura 5.22 - Caso 2 / Fator de segurança para rebaixamento completo da seção $138+50$

Figura 5.23 - Caso 2 / Linha freática para menor FS durante rebaixamento completo da seção $138+50$

Figura 5.24 - Saída do tapete drenante obstruído 138

Figura 5.25 - Sistema de drenagem obstruído 


\section{Lista de Tabelas}

Tabela 3.1 - Caracterização e índices físicos da argila do maciço compactado (IECO e ELC, 1992)

Tabela 3.2 - Valores de permeabilidade obtidos no permeâmetro de carga variável (IECO e ELC, 1982)

Tabela 3.3 - Correlações para obtenção dos parâmetros de resistência (IECO e ELC, 1982)

Tabela 3.4 - Caracterização e índices físicos do solo de fundação (IECO e ELC, 1992)

Tabela 3.5 - Parâmetros de resistência da fundação (IECO e ELC, 1992, 1977)

Tabela 4.1 - Resumo das principais características das seções $\quad 76$

Tabela 4.2 - Permeabilidades adotada no modelo 79

Tabela 4.3 - Resultado da calibração do modelo para piezômetros no saprolito

Tabela 4.4 - Resultado da calibração do modelo para piezômetros na argila

Tabela 4.5 - Resultados da correlação entre valores lidos e simulados do PS-L-18

Tabela 4.6 - Resultados da correlação entre valores lidos e simulados do PS-L-20

Tabela 4.7 - Resultados da correlação entre valores lidos e simulados do PS-L-21

Tabela 4.8 - Resultados da correlação entre valores lidos e simulados do PS-L-22

Tabela 4.9 - Resultados da correlação entre valores lidos e simulados do PS-L-23

Tabela 4.10 - Resultados da correlação entre valores lidos e simulados do PS-L-24

Tabela 4.11 - Resultados da correlação entre valores lidos e simulados do PS-L-25 
Tabela 4.12 - Resultados da correlação entre valores lidos e simulados do PS-L-26

Tabela 4.13 - Parâmetros de Resistência 100

Tabela 4.14 - Fatores de segurança mínimos no período estudado 108

Tabela 4.15 - Dados estatísticos das variáveis aleatórias 109

Tabela 4.16 - Cálculo da variância do FS da seção 129+50 com NAR determinístico

Tabela 4.17 - Cálculo da variância do FS na seção 129+50 com NAR como variável aleatória

Tabela 4.18 - Cálculo da variância do FS na seção 132+00 com NAR determinístico

Tabela 4.19 - Cálculo da variância do FS na seção 132+00 com NAR como variável aleatória

Tabela 4.20 - Cálculo da variância do FS na seção 135+50 com NAR determinístico

Tabela 4.21 - Cálculo da variância do FS na seção 135+50 com NAR como variável aleatória

Tabela 4.22 - Cálculo da variância do FS na seção 138+50 com NAR determinístico

Tabela 4.23 - Cálculo da variância do FS na seção 138+50 com NAR como variável aleatória

Tabela 4.24 - Resumo da probabilidade de ruptura das 4 seções $\quad 116$

Tabela 4.25 - Coeficientes de variação volumétrica do solo

Tabela 5.1 - Relação entre NAR, poropressões e FS na seção 129+50

Tabela 5.2 - Relação entre NAR, poropressões e FS na seção 135+50

Tabela 5.3 - Relação entre NAR, poropressões e FS na seção 138+50

Tabela 5.4 - Variação do FS para os casos de rebaixamento rápido na seção 129+50

Tabela 5.5 - Variação do FS para os casos de rebaixamento rápido na seção $135+50$

Tabela 5.6 - Variação do FS para os casos de rebaixamento rápido na seção $138+50$ 


\section{Lista de Abreviaturas}

$\begin{array}{ll}\text { BTME } & \text { Barragem de Terra da Margem Esquerda de Itaipu } \\ \text { BTMD } & \text { Barragem de Terra da Margem Direita de Itaipu } \\ \text { CESP } & \text { Companhia Energética de São Paulo } \\ \text { FS } & \text { Fator de Segurança } \\ \text { MR-L } & \text { Marco de Referência da BTME } \\ \text { NAR } & \text { Nível d'Água do Reservatório } \\ \text { Pr } & \text { Probabilidade de Ruptura } \\ \text { PS-L } & \text { Piezômetro Standpipe da BTME } \\ \text { PZ-L } & \text { Medidor de Nível d'Água da BTME } \\ \text { UHI } & \text { Usina Hidrelétrica de Itaipu } \\ & \end{array}$


"Quanto mais você sabe, mais você percebe que nada sabe!"

Sócrates 


\section{Introdução}

Itaipu Binacional é uma usina hidrelétrica localizada no Rio Paraná, que divide Brasil e Paraguai, tendo à margem esquerda (lado brasileiro) a cidade de Foz do Iguaçu e à margem direita (lado paraguaio) a cidade de Hernandárias. Trata-se de um empreendimento construído e mantido pelos dois países. A usina possui 20 turbinas, totalizando uma capacidade instalada de $14.000 \mathrm{MW}$, seu produto é igualmente dividido entre ambos países.

A barragem possui uma série de estruturas que totalizam $7.919 \mathrm{~m}$ de extensão e podem ser vistas na Figura 1.1.

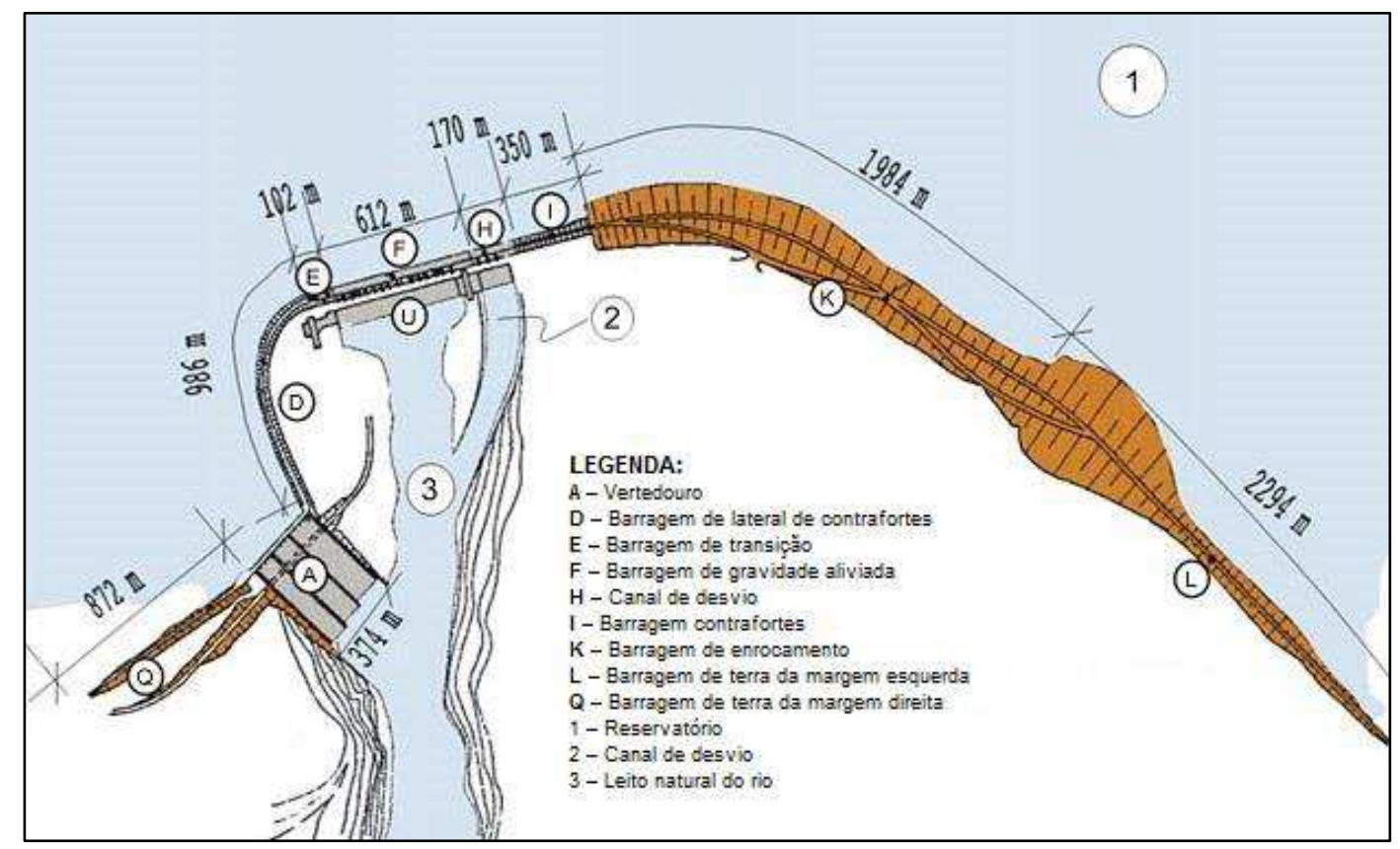

Figura 1.1 - Disposição completa da barragem de Itaipu (Adaptado de Itaipu Binacional, 2009)

O barramento inicia-se na margem direita com a barragem de terra da margem direita - BTMD (Q), seguida pelo vertedouro (A) e pela barragem de contrafortes (D e E). Esta segue até o leito do rio onde tem início a barragem de gravidade aliviada (F) onde estão localizados 16 dos 20 condutos forçados. Os outros 4 condutos forçados ficam na barragem de concreto maciço $(\mathrm{H})$, construída no canal 
de desvio - utilizado no período de construção da barragem principal. $\mathrm{Na}$ continuação da barragem maciça há mais um trecho de barragem de contrafortes (I), seguida pela barragem de enrocamento $(K)$ e a barragem de terra da margem esquerda - BTME (L), que faz o fechamento da estrutura na ombreira esquerda.

O reservatório da Usina Hidrelétrica Itaipu (UHI) possui uma área de 1.350 $\mathrm{km}^{2}$, indo de Foz do Iguaçu até Guaíra, $150 \mathrm{~km}$ ao norte. O nível médio do reservatório é na cota $220 \mathrm{~m}$.

A Figura 1.2 mostra uma vista geral da barragem a partir da margem esquerda.

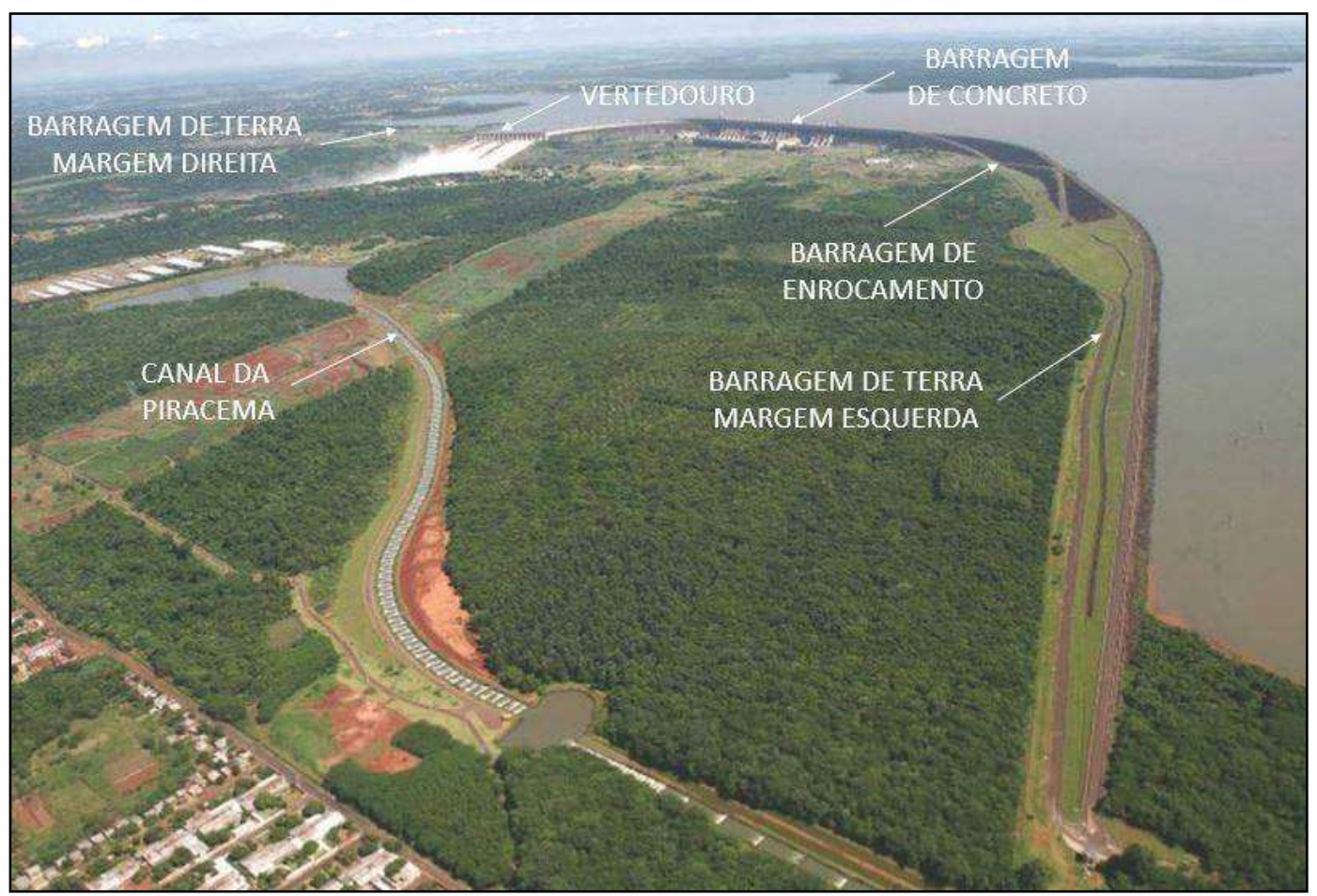

Figura 1.2 - Vista geral da barragem (Adaptado de Itaipu Binacional, 2009)

\section{1}

\section{Justificativa e Objetivos}

Após o enchimento do reservatório em 1984, durante um longo período, o nivel do lago se manteve com pequenas variações, aproximadamente $1,5 \mathrm{~m}$ (entre as cotas $219,00 \mathrm{~m}$ e $220,50 \mathrm{~m}$ ), permanecendo por curtos períodos de tempo em cotas mais baixas. No entanto, entre os anos de 2012 e 2015, esta variação aumentou para aproximadamente $4 \mathrm{~m}$ (entre as cotas $216,50 \mathrm{~m}$ e $220,50 \mathrm{~m}$ ) e o reservatório passou a permanecer em níveis mais baixos por períodos de tempo maiores.

Neste mesmo período é possível notar, por meio das campanhas de levantamento altimétrico, que um trecho da BTME apresentou recalques na ordem 
de $5 \mathrm{~cm}$. Fato considerado atípico já que as leituras estavam estabilizadas desde o final do enchimento do reservatório com variações na faixa de 1 a $2 \mathrm{~cm}$.

Busca-se neste trabalho estudar o comportamento de um trecho da BTME no período que o reservatório apresentou comportamento atípico e prever o comportamento da estrutura mediante efeitos de rebaixamento rápido ou obstrução do sistema de drenagem. Sabe-se que alterações no fluxo e carregamento da estrutura podem provocar um novo estado de tensões e desestabilizar ou deformar o maciço compactado.

Desta forma, os objetivos específicos são:

- Análise de fluxo: verificar poropressões e a linha freática durante o período;

- Análise de estabilidade: cálculo de fatores de segurança (FS) e superfic ies de ruptura para taludes de montante e jusante e cálculo de probabilidade de ruptura do talude de jusante;

- Análise de deformações: verificar possíveis recalques ocorridos devido comportamento do reservatório;

- Estudos de casos: simular condições de fluxo permanente, rebaixamento rápido e obstruções no sistema de drenagem a fim de prever o comportamento da estrutura.

\section{2}

\section{Estrutura da Dissertação}

Este trabalho foi organizado em seis capítulos, sendo este uma breve apresentação da Barragem de Itaipu, da motivação do estudo e a definição dos objetivos gerais e específicos.

No Capítulo 2 é apresentada uma revisão bibliográfica dividida de acordo com os temas estudados, são eles: análise de fluxo, análise de estabilidade, análise de recalques, instrumentação em barragens e métodos dos elementos finitos.

O Capítulo 3 descreve as características geométricas e geotécnicas da BTME e apresenta dados hidrometeorológicos e da instrumentação desde sua construção. Neste capítulo é possível se inteirar sobre a estrutura a ser estudada e sobre as motivações do estudo. 
O Capítulo 4 mostra como foi feita a modelagem da estrutura, a definição das condições de contorno e as análises referente ao período proposto.

No Capítulo 5 são apresentados estudos de caso como, por exemplo, rebaixamento rápido do NAR, fluxo permanente em cotas mais altas e obstruções no sistema de drenagem.

No Capítulo 6 são apresentadas as principais conclusões obtidas com o presente trabalho, bem como sugestões de novos trabalhos que podem ser complementares ao tema. 


\section{2 Revisão Bibliográfica}

Neste capítulo será abordada a revisão bibliográfica que foi separada nos seguintes assuntos: análise de fluxo, análise de estabilidade, análise de recalque s, instrumentação em barragens e método dos elementos finitos.

\section{1}

\section{Análise de Fluxo}

Materiais permeáveis são aqueles que permitem ser penetrados ou percolados por outra substância, em geral um gás ou fluido. O solo, por exemplo, é constantemente permeado por água ou ar, pois, sua estrutura é formada por várias partículas interconectadas que formam poros e trincas que permitem a passagem dos fluidos. A rocha em si possui permeabilidade muito baixa, porém quando se trata de um maciço rochoso, o mesmo possui juntas e fraturas que permitem a passagem de água, sendo assim, a permeabilidade das rochas é determinada predominantemente pelo padrão de descontinuidades que existe. O fluxo que ocorre em um maciço está ligado a permeabilidade que por sua vez é determinante na velocidade da água infiltrada.

A permeabilidade de um material é uma das propriedades geotécnicas dos materiais que possui maior faixa de variação, por esse motivo um projeto e construção de uma estrutura hidráulica é um grande desafio, pois exige dimensionar a estrutura e aplicar o material corretamente para que o sistema seja eficiente (Cedergren, 1977).

O comportamento dos fluidos é regido pela equação de Bernoulli, onde a carga total em um ponto é função da pressão, velocidade e carga de elevação, conforme Equação 2.1: 


$$
h=\frac{u}{\gamma_{w}}+\frac{v^{2}}{2 g}+Z
$$

Onde: h: carga total;

u: pressão;

v: velocidade;

g: aceleração da gravidade;

$\gamma_{w}$ : peso específico da água.

Em solos, o termo que considera a velocidade é desconsiderado pelo fato da velocidade de percolação ser insignificante. Sendo assim a carga total em um ponto pode ser obtida por meio da Equação 2.2:

$$
h=\frac{u}{\gamma_{w}}+Z
$$

A diferença de carga entre dois pontos gera um fluxo, tendendo à estabilização das cargas totais. Essa diferença de carga pode ser expressa de forma adimensional pelo gradiente hidráulico, conforme Equação 2.3:

$$
i=\frac{\Delta h}{L}
$$

Sendo: i: gradiente hidráulico;

$\Delta \mathrm{h}$ : diferença de carga total entre dois pontos;

L: distância entre os dois pontos.

Em 1850, experimentalmente, Henri Philibert Gaspard Darcy publicou uma equação empírica para determinação da velocidade da água em solos saturados. Darcy observou a percolação em experimentos e definiu que a velocidade é definida em função do gradiente hidráulico e da permeabilidade do material (representada pelo coeficiente de permeabilidade), conforme mostrado na Equação 2.4:

$$
v=k \cdot i
$$

Sendo: v: velocidade;

k: permeabilidade do solo;

i: gradiente hidráulico. 
Seguindo o conceito da mecânica dos fluidos, Darcy concluiu que a vazão em um solo pode ser obtida por meio do produto da velocidade e área de uma seção, conforme Equação 2.5:

$$
Q=k \cdot i . A
$$

Sendo: Q: vazão;

$\mathrm{k}$ : permeabilidade do solo;

i: gradiente hidráulico;

A: área da seção que ocorre o fluxo.

Se existe um fluxo estabelecido em um solo saturado, sem variação do volume de vazios, a quantidade de água que entra na face de um elemento de solo é a mesma quantidade que deve sair por outra face do elemento num determinado espaço de tempo. Essa condição pode ser expressa pela Equação 2.6 (Casagrande, 1937):

$$
\frac{\partial u}{\partial x}+\frac{\partial v}{\partial y}+\frac{\partial w}{\partial z}=0
$$

Onde u, v, e w são componentes de velocidade. Considerando que no caso de barragens a análise é feita em duas dimensões e aplicando a lei de Darcy, tem-se a Equação 2.7:

$$
\frac{\partial}{\partial \mathrm{x}}\left(k_{x} \frac{\partial \mathrm{H}}{\partial \mathrm{x}}\right)+\frac{\partial}{\partial y}\left(k_{y} \frac{\partial \mathrm{H}}{\partial \mathrm{y}}\right)=0
$$

Na maioria dos casos que envolvem fluxo de água no solo, as condições de contorno são conhecidas, como, por exemplo, no caso de fluxo abaixo de uma cortina impermeável ou fundação de uma barragem. Entretanto, no corpo da barragem ocorre um fluxo não confinado, onde não se conhece a linha de fluxo que define a superficie de água infiltrada. Neste caso deve ser usada uma solução gráfica baseada na rede de fluxo ou alguma solução numérica aproximada (Casagrande, 1937).

Existem diversos métodos para solução de problemas de percolação em 2D, alguns deles são citados a seguir:

- Método analítico - a solução analítica da equação pode ser resolvida por meio de uma função potencial complexa; 
- Método gráfico - as redes de fluxo representam o caminho percorrido pela água e as correspondentes linhas equipotenciais, trata-se da representação gráfica das duas famílias de curvas que satisfazem a Equação 2.7. Tal solução é explicada com detalhes por Casagrande (1937) e Cedergren (1977);

- Modelos físicos - modelos de areia, por exemplo, são usados para representar problemas de percolação com condições de contorno complexas, efeitos de heterogeneidades, etc;

- Modelos estatísticos - Simulações de Monte Carlo podem apresentar solução para casos de fluxo permanente.

\subsection{1}

\section{Fluxo em Barragens}

A força exercida pela água constitui fator importante na segurança de barragens, por esse motivo o fluxo, seja permanente ou transiente, tanto pelo maciço compactado ou fundação deve ser adequadamente controlado.

A percolação em uma barragem pode levar à ruptura da estrutura a partir de duas causas principais: carreamento de materiais para fora do maciço, causando erosões e o fenômeno denominado pipping, ou uma percolação descontrolada que provoque a saturação do maciço com excessivas poropressões.

O maciço deve ser construído de maneira a prevenir danos causados pela pressão da água infiltrada. A análise do fluxo pelo corpo da barragem é primordial para definição do material e geometria, tanto do maciço como dos elementos que compõem a estrutura da barragem. É fundamental que seja previsto nas análises a utilização, da melhor maneira possível, dos materiais disponíveis na região.

A infiltração de água pela fundação constitui um fator importante a ser observado na investigação geotécnica. Um solo ou rocha permeável não identificado e não tratado adequadamente pode provocar o pipping e trazer graves riscos à estrutura.

Os problemas de pipping podem ser evitados cobrindo toda área sujeita a infiltração com filtros e drenos, para dessa maneira direcionar e conduzir a água infiltrada de maneira segura para fora do maciço. Os sistemas de drenagem da barragem devem, sempre que possível, ser independentes da descarga do 
reservatório para facilitar a leitura e observação do fluxo proveniente de infiltração (Cedergren, 1977).

Em geral, a vazão que percola pelo núcleo é pequena comparada com a vazão pela fundação, seja ela em solo ou rocha. A vazão pela fundação é, geralmente, pelo menos duas vezes maior do que pelo corpo da barragem (Cruz, 1996).

\subsection{2}

\section{Controle de Fluxo em Barragens}

Existem duas premissas que devem ser consideradas no projeto de uma barragem, a primeira consiste em estabelecer uma forma de manter a água fora do maciço, dificultando a infiltração. A segunda consiste em usar métodos de drenagem para controlar o fluxo e direcionar a água para fora do maciço, a jusante da barragem, sem prejudicar a estrutura.

Referente a primeira premissa, para diminuir a infiltração tanto no maciço compactado como na fundação, podem ser utilizadas diversas técnicas, entre elas: trincheiras, cortinas de injeção, paredes diafragma, tapetes impermeáveis a montante ou uma face impermeável no talude de jusante.

As trincheiras, cortinas de injeção, tapetes impermeáveis e as demais técnicas utilizadas para diminuir a infiltração, têm por objetivo diminuir o gradiente hidráulico e impossibilitar um fluxo no sentido jusante-montante. Em todas as propostas, é implantado algum elemento impermeabilizante em uma parte potencialmente permeável da estrutura, que força o fluido a percorrer um caminho maior e perder energia nesse trajeto.

Já as técnicas utilizadas para controle e condução do fluxo para fora do maciço podem ser: zoneamento do aterro, filtro chaminé, poços de alívio, drenos longitudinais, tapetes drenantes, entre outros (Casagrande, 1937). Os principa is são descritos a seguir.

\section{Aterro Zonado}

O aterro zonado utiliza um núcleo com função de impermeabilização e duas abas que completam a estrutura tendo função predominantemente estrutural, esse núcleo impermeável precisa ser construído de forma que tenha a menor 
permeabilidade possível, já para as abas que completam a estrutura a característica mais importante passa a ser a resistência.

\section{Drenos Longitudinais}

Os drenos longitudinais e tapetes drenantes são altamente eficientes em locais com fundações uniformes e aterros de materiais isotrópicos $(\mathrm{kh}=\mathrm{kv})$. Quando devidamente projetados, uma pequena faixa de dreno instalada no pé da barragem pode controlar a infiltração, excluindo o perigo de entupimento ou pipping.

\section{Drenos Chaminé}

Constantemente o material compactado de um maciço apresenta permeabilidade horizontal consideravelmente maior que a vertical devido ao processo construtivo. Para interceptar o fluxo adequadamente, associa-se um dreno chaminé ao dreno longitudinal ou tapete drenante. Esse dreno pode ser vertical ou inclinado e deve ter altura suficiente para interceptar o fluxo considerando a anisotropia do solo.

Quando bem dimensionado, um dreno chaminé permite que o material a jusante não exija um controle de permeabilidade rigoroso. Essa parte do maciço terá função predominantemente estrutural, reduzindo assim o custo do material e processo construtivo.

\section{Poços de Alívio}

Quando trincheiras não são suficientes para impedir a passagem de água pela fundação, os poços de alívio são uma opção para aliviar a pressão exercida pela água. Os poços são dispostos a jusante da barragem de forma a manter a pressão da água na fundação dentro dos níveis seguros.

\section{2}

\section{Análise de Estabilidade}

O Princípio das Tensões Efetivas de Terzaghi estabelece que a tensão normal total num plano qualquer de um elemento de solo saturado, é constituída de duas parcelas: a tensão transmitida entre as partículas, chamada de tensão efetiva $\left(\sigma^{\prime}\right)$, e 
a pressão da água (em solos saturados), chamada de poropressão (u). Assim, a tensão total é definida conforme Equação 2.8 (Terzaghi, 1936):

$$
\sigma=u+\sigma^{\prime}
$$

A tensão efetiva controla o comportamento do solo, os estudos para avaliação de resistência e deformabilidade do solo devem ser feitos com base nela. Alterações nos carregamentos podem elevar as poropressões e induzir o solo a ruptura (Pinto, 2006).

A resistência do solo, como em todos materiais granulares, é determinada pelas forças de atrito exercidas entre os grãos de solo durante um deslizamento. Conforme definida no critério de Mohr-Coulomb, é composta pela coesão (c) e ângulo de atrito $(\phi)$, sendo que existe uma relação entre a tensão aplicada no solo e sua resistência, essa relação é expressa conforme Equação 2.9 (Lambe e Whitman, 1969; Bishop e Henkel, 1976):

$$
S=c^{\prime}+(\sigma-u) \tan \phi^{\prime}
$$

As incertezas relacionadas a uma análise de estabilidade não são exclusivamente devidas às aproximações feitas pelos métodos de análise, são também relacionadas aos métodos de amostragens e tipos de ensaios. Essas condições devem representar com maior precisão possível as condições de campo para obtenção de parâmetros equivalentes (Bishop, 1955).

Para obtenção dos parâmetros de resistência em laboratório com condições de drenagem controlada, o ensaio triaxial é o mais utilizado. No entanto, o ensaio pode ser realizado de diversas maneiras. Para definição do ensaio adequado é necessário relacioná-los com os problemas práticos que podem ocorrer no local analisado (Bishop e Henkel, 1976).

\subsection{1 \\ Análise Determinística}

A análise determinística consiste na obtenção de um fator de segurança (FS) definido pela relação entre a tensão aplicada no solo e a resistência do mesmo para a referida tensão. Para obtenção do FS de um talude, é definida uma superfície de ruptura e são usadas uma ou mais equações de equilíbrio estático para obtenção do 
fator de segurança de cada superficie assumida. A superficie com o menor FS é definida como superficie crítica (Duncan et al., 2014).

Existem diversos métodos de equilibrio limite que se diferenciam na estatística empregada nas equações e na suposição adotada para representar o problema. São os principais: Fellenius, Bishop, Spencer, Janbu e Morgenstern-Price (Fredlund e Krahn, 1977). Todos estes métodos trabalham com o método das fatias, o qual divide a superfície de ruptura pré-definida em determinado número de pedaços e as equações de equilíbrio são escritas para cada uma delas (Duncan et al., 2014).

O método de Fellenius é o mais comum aplicado para superficies de ruptura circulares. Nele são ignoradas as forças entre fatias, pois são consideradas paralelas a base e, portanto, se anulam. Entretanto, o princípio que a ação é igual a reação não é aplicável entre as fatias (Figura 2.1), isso pode induzir um erro considerável no fator de segurança resultante (Fredlund e Krahn, 1977).

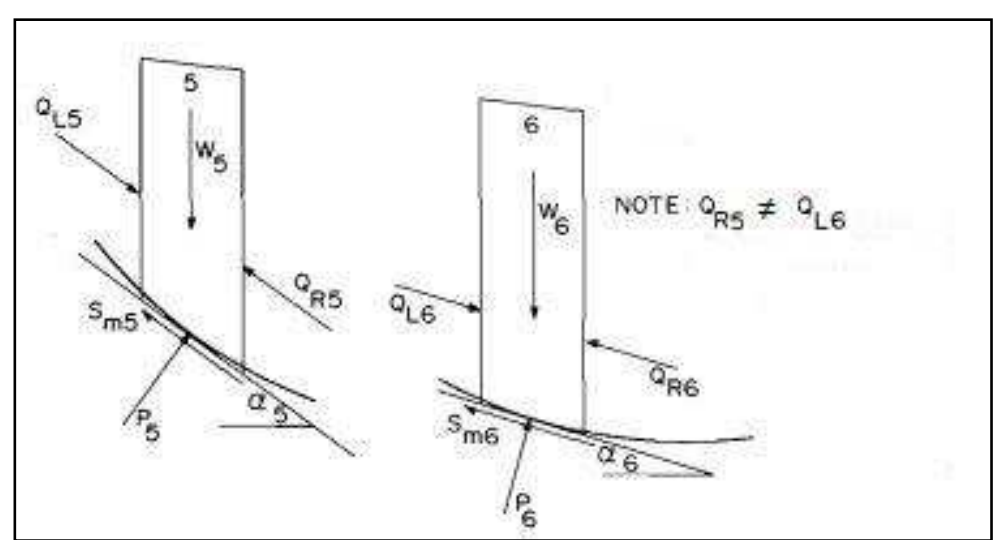

Figura 2.1 - Forças entre fatias no método de Fellenius (Adaptado de Fredlund e Krahn, 1977)

As forças exercidas numa fatia pelo método de Fellenius são mostradas na Figura 2.2. O método atende apenas à condição de equilíbrio de momento. 


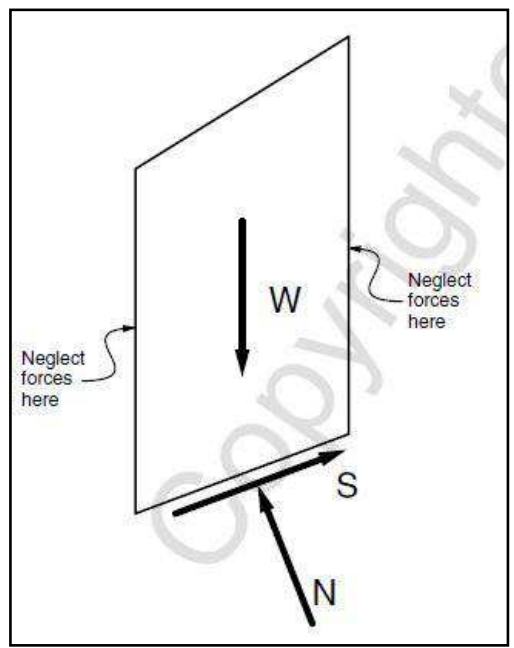

Figura 2.2 - Fatia com as forças consideradas no Método de Fellenius (Duncan et al., 2014)

O método de Bishop também é aplicado para superficies de ruptura circulares. Nele as forças entre fatias são consideradas como horizontais, ou seja, não são consideradas tensões de cisalhamento entre fatias, apenas força normal. São utilizadas as equações de equilíbrio para forças verticais e momentos. Uma fatia com a representação das forças consideradas é mostrada na Figura 2.3 (Fredlund e Krahn, 1977; Duncan et al., 2014).

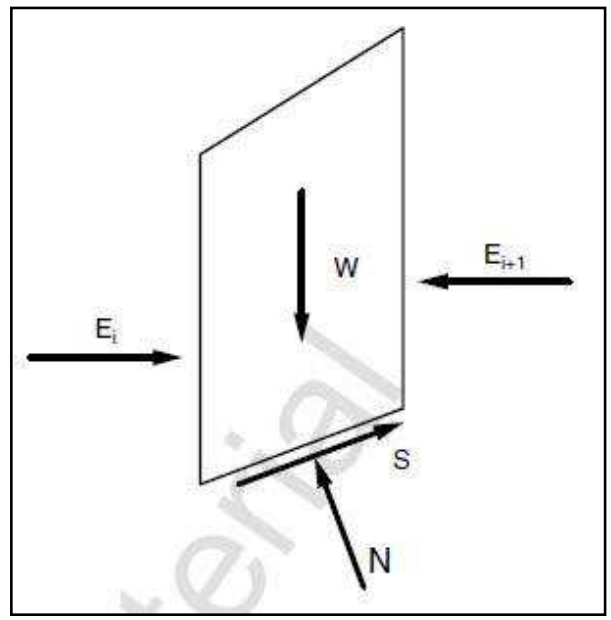

Figura 2.3 - Fatia com forças consideradas no Método de Bishop (Duncan et al., 2014)

O método de Spencer considera as forças normais e cisalhantes entre fatias e assume que existe uma relação constante entre elas. Neste método são atendidas as condições de equilibrio de forças verticais, horizontais e momentos. A Figura 2.4 mostra uma representação das forças entre fatias (Fredlund e Krahn, 1977; Duncan et al., 2014). 


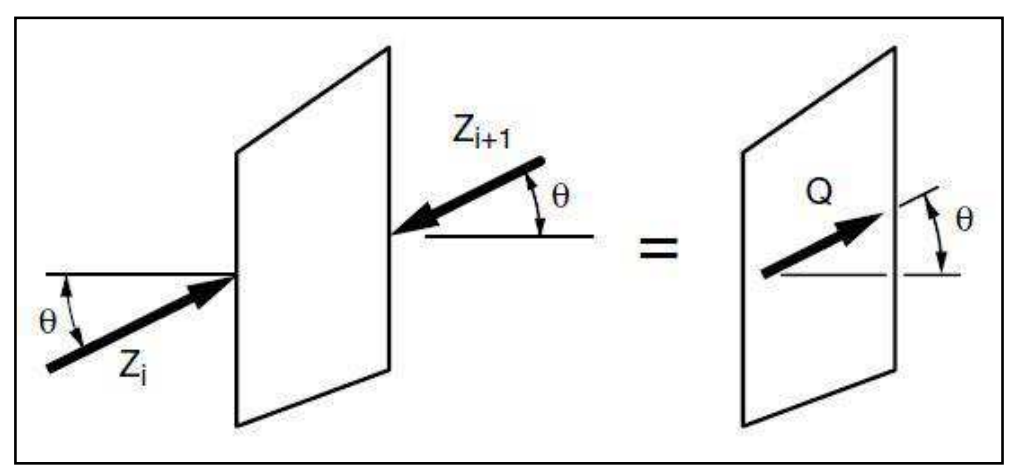

Figura 2.4 - Representação das forças entre fatias no método de Spencer (Duncan et al., 2014).

O método simplificado de Janbu considera as forças normais entre fatias e atende condições de equilíbrio de forças horizontais. Esses critérios fazem com que o fator de segurança seja, frequentemente, menor que o obtido com métodos rigorosos. Por isso Janbu analisou diversos casos e propôs uma correção com base nos parâmetros de resistência e forma de ruptura. Esse parâmetro deve ser usado com precaução (Fredlund e Krahn, 1977; Duncan et al., 2014).

Morgenstern-Price trata-se de um método que considera as forças normais e cisalhantes entre fatias, a relação entre elas é considerada variável. São consideradas as equações de equilíbrio de forças e de momentos utilizando a técnica numérica de Newton-Raphson. O método de Morgenstern-Price apresenta certa semelhança com o método de Spencer, o que diferencia ambos é a consideração sobre as forças entre fatias, pois, no método de Spencer são consideradas com uma única inclinação (Fredlund e Krahn, 1977; Duncan et al., 2014).

Fredlund e Krahn (1977) citam que, para superficies de ruptura circulares, o método de Bishop resulta em fatores de segurança semelhantes, em magnitude, com os métodos de Spencer e Morgenstern-Price. Isso ocorre devido a pequena influência da força entre fatias no equilíbrio de momentos. Em diversos casos estudados a diferença entre eles foi de aproximadamente $0,1 \%$.

Ainda Fredlund e Krahn (1977) apontam que, em se tratando de tempo computacional, os métodos de Spencer e Morgenstern-Price necessitam em média seis vezes o tempo necessário para realização de uma análise no método de Bishop. 


\subsection{2}

\section{Análise Probabilística}

Uma grande dificuldade enfrentada na engenharia geotécnica é associada à incerteza das características dos materiais. Os solos, em geral, apresentam propriedades dificeis de estabelecer e sujeitas a grande variabilidade. Quando a solução é a adoção de grandes fatores de segurança e maior conservadorismo, questões econômicas podem inviabilizar uma obra (Christian et al., 1994).

Essa incerteza no meio geotécnico pode ser tratada a partir de observações e julgamentos do engenheiro geotécnico com base em seu conhecimento de geologia e técnicas estatísticas (Baecher e Christian, 2003).

Por esse motivo os métodos probabilísticos são amplamente aplicados na engenharia geotécnica. Esses métodos consideram a variabilidade das variáveis envolvidas nas análises de segurança estrutural e permitem estimar o índice de confiabilidade e a probabilidade de falha para estrutura (Mafioleti, 2016).

Quando comparado com a análise determinística, não necessariamente um baixo fator de segurança resultará em uma alta probabilidade de ruptura e um fator de segurança alto também não é sinônimo de uma baixa probabilidade de ruptura, essa relação depende do grau de incerteza das variáveis (Silva, 2015).

Sandroni e Sayão (1992) apresentam um procedimento simples para avaliação estatística do fator de segurança de taludes. O estudo visa o cálculo da variância, V[FS], e do índice de confiabilidade, $\beta$, do fator de segurança.

A variância do fator de segurança é calculada por meio da formulação de primeira ordem e segundo momento (métodos FOSM), onde são obtidas as parcelas de variância do FS para cada um dos parâmetros variáveis na análise (c, ф, etc). Tal procedimento permite avaliar a importância de cada variável na composição do FS.

O índice de confiabilidade do fator de segurança é definido pela Equação 2.10:

$\beta=\frac{E[F S]-1}{\sigma[F S]}$

Onde:

$\mathrm{E}[\mathrm{FS}]$ - valor determinístico do FS;

$\sigma[\mathrm{FS}]$ - desvio padrão do FS. 
$\mathrm{O}$ índice de confiabilidade, $\beta$, indica o número de desvios padrão que distancia a ruptura do FS encontrado, ele complementa o valor do FS e permite associar a uma probabilidade de ruptura de acordo com a Figura 2.5.

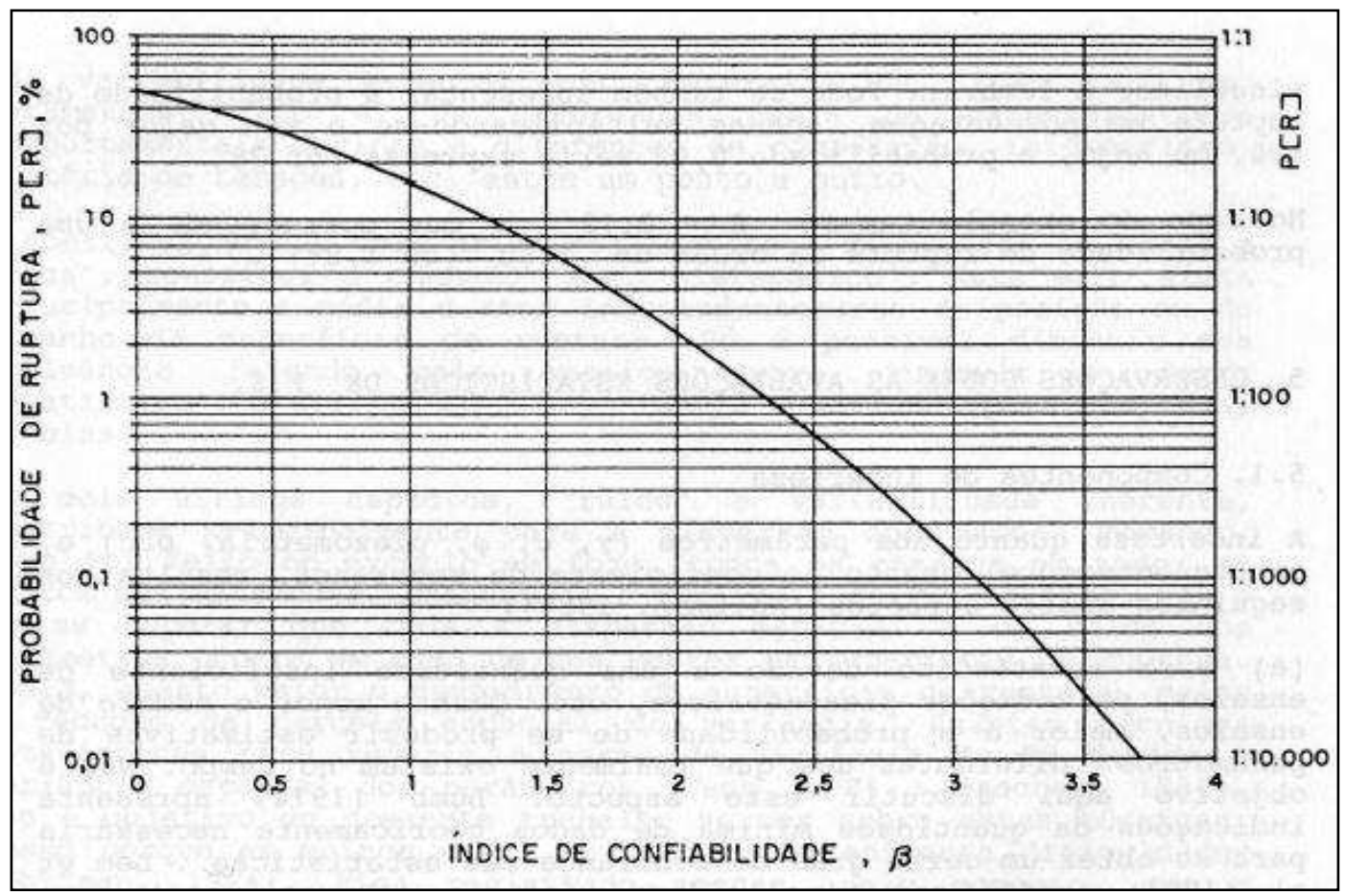

Figura 2.5 - Relação entre índice de confiabilidade e probabilidade de ruptura (Sandroni e Sayão, 1992)

\subsection{3 \\ Estabilidade em Barragens}

A água armazenada através de uma barragem possui grande potencial energético, tornando perigosa uma liberação descontrolada. As principais causas de ruptura de barragens são: galgamento, deslizamentos rotacionais e erosão interna (Penman, 1986).

A estabilidade dos taludes de uma barragem deve ser verificada para três condições: final de construção, fluxo permanente e rebaixamento rápido. As análises devem ser feitas considerando o mecanismo de ruptura em função da geometria da barragem, dos parâmetros geotécnicos do maciço compactado e fundação e das condições de fluxo que estará submetida a barragem. Estas análises devem ser feitas considerando as tensões efetivas, pois são elas que governam majoritariamente o comportamento do solo.

Para a condição de final de construção e regime permanente de operação deve ser verificada a estabilidade para os taludes de montante e jusante. O FS mínimo 
para final de construção é de 1,3 e para regime permanente 1,5. Para condição de rebaixamento rápido, a estabilidade deve ser verificada apenas no talude de montante, neste caso o FS mínimo pode ser 1,0 (Cruz, 1996).

\section{Final de Construção}

$\mathrm{Na}$ condição de fim de construção admite-se que a barragem não está submetida à carga hidráulica. As poropressões no corpo da barragem resultam do estado de tensões e velocidade da construção, enquanto na fundação são função do nível d'água durante a construção (Cruz, 1996).

Esta análise pode ser realizada considerando a construção como uma solicitação drenada ou não drenada. Essa opção deve ser feita considerando o tipo de solo, quando for um solo fino com permeabilidade baixa ao ponto de a drenagem não acompanhar a velocidade de construção, são realizadas análises com parâmetros não drenados, neste caso a análise deve ser feita em termos de tensões totais.

Em alguns casos a condição crítica pode estar relacionada a uma etapa de construção, por esse motivo, a construção em etapas deve ser analisada detalhadamente e a estrutura dimensionada para atender ao critério de estabilidade em todos os estágios (Duncan et al., 2014).

\section{$\underline{\text { Regime Permanente }}$}

A análise de regime permanente parte do pressuposto que as deformações do maciço em virtude de sua construção e do enchimento do reservatório já foram estabilizadas e que existe uma rede de fluxo estabelecida de acordo com o nível da água a montante. As poropressões atuantes no maciço compactado e fundação são obtidas por essa rede de fluxo (Cruz, 1996).

A partir dessas considerações, a resistência do solo deve ser expressa em termos de tensões efetivas com parâmetros drenados, já que não ocorre alterações nas condições de fluxo ou no estado de tensões (Duncan et al., 2014). 


\section{Rebaixamento Rápido}

O fenômeno denominado rebaixamento rápido existe quando a redução do nível d'água a montante ocorre em uma velocidade rápida o suficiente para que o solo não tenha tempo para realizar a drenagem e rebaixamento da linha freática no corpo da barragem simultaneamente. Neste caso as tensões no talude são resistidas pela resistência não drenada (Duncan et al., 2014).

$\mathrm{O}$ rebaixamento rápido tem efeito duplo na estrutura. Primeiramente, estabelece novas condições de fluxo através da barragem, pois o fluxo que tinha um regime permanente passa para um regime transiente até que se equilibre em nova posição após o rebaixamento. Em segundo, a variação de tensões durante o rebaixamento altera as poropressões.

A condição mais crítica é imediatamente após o rebaixamento, pois ocorre uma redução brusca da tensão total, as poropressões continuam elevadas e, por esse motivo, a tensão efetiva é reduzida. Em seguida as poropressões são dissipadas em função do tempo, a tensão efetiva aumenta e o fator de segurança tende a aumentar. Quanto menor a permeabilidade do material, maior será o tempo necessário para esse equillbrio (Morgenstern, 1963).

Assim como existem métodos simplificados utilizados para análises de estabilidade para regime permanente, existem métodos simplificados para análises de estabilidades durante rebaixamento rápido.

Morgenstern (1963) apresenta ábacos que permitem obter fatores de segurança para rebaixamento rápido a partir da proporção do rebaixamento e dos parâmetros aproximados de resistência do solo, considerando quatro diferentes inclinações de talude.

Para este tipo de análise por ábacos, o talude é assumido homogêneo com um único material e parâmetros de resistência uniformes. É assumido, também, que o talude está sob uma fundação impermeável e a dissipação de poropressões é desconsiderada (Morgenstern, 1963).

Os ábacos se diferenciam para diferentes inclinações de talude e coesão efetiva do solo, que é normalizada resultando na equação adimensional: $c^{\prime} / \gamma \mathrm{H}$, sendo $\gamma$ a densidade relativa e $\mathrm{H}$ a altura da barragem. A Figura 2.6 apresenta um exemplo de ábaco para talude com inclinação $1: 3(\mathrm{~V}: \mathrm{H})$ e uma relação $\mathrm{c}^{\prime} / \gamma \mathrm{H}=$ 
0,0125. A proporção do rebaixamento é dada por $\mathrm{L} / \mathrm{H}$, sendo $\mathrm{L}$ a distância vertical da crista ao nível d'água após o rebaixamento e Ha altura da barragem.

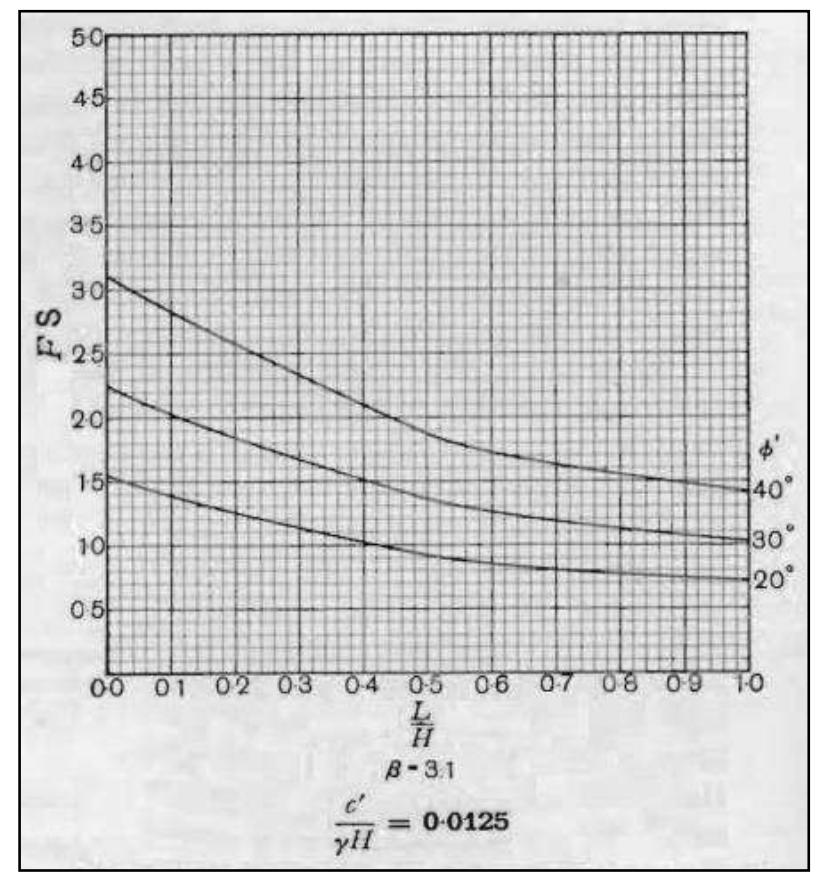

Figura 2.6 - Ábaco para cálculo de FS para rebaixamento rápido (adaptado de Morgenstern, 1963)

Almeida (2013) realizou análises de rebaixamento rápido por meio de análises numéricas e chegou à conclusão que a condição crítica de estabilidade em um talude durante um rebaixamento rápido pode não ocorrer com o reservatório vazio, mas sim quando ainda apresente nível d'água considerável.

\section{3}

\section{Análise de Recalques}

Durante a fase de construção, maciços de terra ou enrocamento estão sujeitos a recalques de vários centímetros, esse deslocamento é definido de acordo com a compressibilidade do material. Os recalques calculados pela teoria clássica do adensamento são usualmente superiores aos observados em campo.

Após a construção podem ocorrer novos recalques na barragem causados pelo enchimento do reservatório e, em casos particulares, por colapso de solos não saturados. Esses recalques têm se mostrado pequenos e não chegam a provocar acidentes (Cruz, 1996).

Recalques em barragens podem acontecer devido ao adensamento do maciço compactado e da fundação ou por deslocamentos provocados por cisalhamento. 
Deve-se ficar atento, pois recalques devido ao adensamento tendem a estabilizar com o tempo, enquanto deslocamentos provocados por cisalhamento tendem a aumentar se o carregamento for mantido ou aumentado.

Pequenas áreas com recalques podem ser consequência de pipping, que pode ser provocado por dimensionamento incorreto do sistema de drenagem, ação de animais, raízes de plantas ou zonas mal compactadas. Para investigação deve ser verificada a magnitude dos recalques, delimitada a área que acontecem e realizada coleta de amostras para verificar as condições do material ou realizados poços de observação para inspeção visual (Jansen, 1922).

\subsection{1}

\section{Adensamento}

Quando aplicada uma carga em um solo saturado, as partículas de solo tentam se rearranjar de forma que fiquem mais próximas umas das outras. Entretanto, quando o solo está saturado, para que ocorra esse rearranjo das partículas é necessária a expulsão da água existente entre elas. De acordo com as características do solo e da velocidade da aplicação da carga, o carregamento pode ser considerado drenado ou não drenado.

No carregamento drenado não há excesso de poropressão, pois, a água é expulsa dos poros na mesma proporção que o carregamento ocorre. No caso não drenado a água não consegue sair do solo na mesma velocidade de aplicação do carregamento e, neste caso, uma parte da tensão aplicada é absorvida pela água, resultando em excesso de poropressões. Esse excesso de poropressão é dissipado com o tempo de acordo com a permeabilidade do solo.

A dissipação das poropressões permite o rearranjo das partículas de solo, provocando um incremento na tensão efetiva e a redução do volume do solo. Esse fenômeno é denominado adensamento (Terzaghi, 1925).

Para previsão de recalques por adensamento, frequentemente é utilizada a teoria unidimensional do adensamento desenvolvida por Terzaghi. Porém, a teoria adota algumas hipóteses que não representam o comportamento real dos solos na maioria dos casos (Kochen e Zagottis, 1983). 
As principais premissas na teoria de Terzaghi são:

1) O solo é homogêneo;

2) O solo está completamente saturado;

3) As partículas sólidas e a água são incompressíveis;

4) A compressão e o fluxo ocorrem somente na direção vertical;

5) As deformações são pequenas;

6) A lei de Darcy é válida para todos os gradientes;

7) Os coeficientes de permeabilidade e de adensamento permanecem constantes durante todo o processo;

8) Há uma relação única entre índice de vazios e tensão vertical efetiva, independentemente do tempo.

Sobre essas premissas, há evidências que mostram que a lei de Darcy não é válida para gradientes muito pequenos. O coeficiente de permeabilidade, assim como o de adensamento, não é constante e diminui no decorrer da redução do índ ice de vazios. Outra observação é referente à relação entre o índice de vazios e a tensão vertical efetiva, resultados experimentais mostram que essa relação não é independente do tempo (Knappett e Craig, 2012).

A partir dessas premissas, as equações que governam o adensamento são as relações tensão-deformação (Equação 2.11) e equação da continuidade (Equação 2.12):

$\frac{\partial e}{\partial \sigma^{\prime}}=-a_{v}$

$k \frac{\partial^{2} h}{\partial z^{2}}=\frac{1}{(1+e)} \frac{\partial e}{\partial t}$

As Equações 2.11 e 2.13 podem ser combinadas formando a Equação 2.14:

$$
\frac{k(1+e)}{a_{v}} \frac{\partial^{2} h}{\partial z^{2}}=-\frac{\partial \sigma \prime}{\partial t}
$$

Quando se discretiza a carga total (h) em carga de elevação e poropressão, a carga de elevação é igual a zero por simplificação e se obtém a Equação 2.15:

$$
\frac{k(1+e)}{\gamma_{w} a_{v}} \frac{\partial^{2} u}{\partial z^{2}}=-\frac{\partial \sigma^{\prime}}{\partial t}
$$


O coeficiente desta equação é chamado de coeficiente de adensamento $\left(\mathrm{c}_{\mathrm{v}}\right)$, sendo ele:

$$
c_{v}=\frac{k(1+e)}{\gamma_{w} a_{v}}
$$

Ou simplificando com o coeficiente de variação de volume $\left(\mathrm{m}_{\mathrm{v}}\right)$ :

$$
c_{v}=\frac{k}{\gamma_{w} m_{v}}
$$

Assim, a equação de adensamento de Terzaghi pode ser escrita em termos de tensões totais da seguinte maneira (Lambe e Whitman, 1969):

$$
c_{v} \frac{\partial^{2} u}{\partial z^{2}}=\frac{\partial u}{\partial t}-\frac{\partial \sigma}{\partial t}
$$

$\mathrm{O}$ coeficiente de adensamento $\left(\mathrm{c}_{\mathrm{v}}\right)$ é o parâmetro do solo relacionado à velocidade de adensamento, por meio dele é estimado o tempo que o recalque levará para ocorrer. Existe uma série de fatores que dificultam a determinação e a utilização desse parâmetro. Um exemplo está relacionado ao seu comportamento para solos normalmente adensados ou sobreadensados. $\mathrm{O} \mathrm{c}_{\mathrm{v}}$ para solos abaixo da tensão de sobreadensamento é consideravelmente menor que para tensões acima da tensão de sobreadensamento. Isso faz com que o valor varie durante o processo de adensamento.

Outra dificuldade é relacionada à definição de um valor por meio de ensaios de adensamento, existem dois métodos para definição do valor de $\mathrm{c}_{\mathrm{v}}$ a partir destes ensaios: Método de Casagrande e Método de Taylor. Em casos gerais ambos apresentam valores de $\mathrm{c}_{\mathrm{v}}$ diferentes.

A teoria unidimensional de Terzaghi é bastante utilizada e ensinada nas escolas de engenharia e utilizada pelo engenheiro geotécnico, mesmo quando métodos mais avançados têm sido desenvolvidos (Duncan, 1993).

Diversos autores tentaram generalizar a teoria unidimensional de Terzaghi assumindo condições de deformações e fluxo em três dimensões. Fazendo essa análise em três dimensões, é possível observar que, quando submetido a uma carga externa, o solo se deforma mesmo sem drenagem. Sendo assim essa distribuição de tensões é determinada pelos parâmetros elásticos não-drenados. Após o adensamento, com a expulsão da água dos vazios, a distribuição de tensões é 
determinada pelos parâmetros elásticos drenados, ou seja, as tensões não são constantes durante o adensamento.

Biot (1941) propôs uma teoria que estende a teoria de Terzaghi para três dimensões e estabelece equações válidas para cargas variáveis com o tempo. Em sua teoria são assumidas as seguintes propriedades básicas do solo:

1) O material é isotrópico;

2) Ocorre reversibilidade das relações de tensão-deformação nas condições finais de equilíbrio;

3) Relação tensão-deformação linear;

4) Pequenas deformações;

5) A água nos poros é incompressível;

6) A água pode conter bolhas de ar;

7) A lei de Darcy é válida.

A formulação rigorosa de Biot (1941) para adensamento em duas ou três dimensões requer que a equação da continuidade seja acoplada às equações de equilíbrio, para isso são necessárias as relações constitutivas para a estrutura do solo, para a água e o ar nele contidos. Essas relações constitutivas são resumidas em suas formas de elasticidade antes da formulação das equações de adensamento (Fredlund e Rahardjo, 1993).

Em suma, a equação do adensamento proposta por Biot (1941) para duas dimensões pode ser escrita da seguinte maneira (Kochen e Zagottis, 1983):

$$
c_{v}\left(\frac{\partial^{2} u}{\partial x^{2}}+\frac{\partial^{2} u}{\partial y^{2}}\right)+\frac{\partial}{\partial t}\left(\frac{\sigma_{x}+\sigma_{y}}{2}\right)=\frac{\partial u}{\partial t}-\frac{\partial \sigma}{\partial t}
$$

Sendo o coeficiente de adensamento $\left(c_{v}\right)$ :

$$
c_{v}=\frac{k E^{\prime}}{2 \gamma_{w}\left(1-2 v^{\prime}\right)\left(1+v^{\prime}\right)}
$$

A teoria de Biot é matematicamente mais sofisticada, porém sua aplicação, embora complexa, apresenta menos limitações que a de Terzaghi. Sua utilização é justificada por uma melhor compreensão do fenômeno de adensamento tridimensional, do comportamento de fundações sobre solos compressíveis e pelas economias recorrentes (Kochen e Zagottis, 1983). 
De acordo com as teorias do adensamento que assumem uma relação entre o índice de vazios e a tensão efetiva, quando o excesso de poropressão é dissipado e a poropressão passa a ser hidrostática, constata-se o fim do adensamento. Porém, na realidade, alguns solos continuam diminuindo de volume. Essa compressão secundária é atribuída a suscetibilidade do solo a deformações viscosas ou fluênc ia devido a manutenção da carga aplicada e o rearranjo lento das partículas (Mitchell e Soga, 2005).

A taxa de compressão secundária $(\mathrm{C} \alpha)$ é determinada pela película viscosa de água adsorvida que envolve as partículas de solo. Nas zonas de contato da película ocorre um fluxo viscoso bastante lento que permite que as partículas se aproximem e a viscosidade da película diminua, resultando no decréscimo da taxa de compressão (Knappett e Craig, 2012).

A compressão secundária ocorre independentemente da compressão primária, assim, é possível utilizar o valor de $\mathrm{C} \alpha$ obtido a partir do ensaio oedométrico convencional para estimativas de recalques secundários em campo. Existe uma relação única e linear entre $\mathrm{Cc}$ e $\mathrm{C} \alpha$. Portanto com a constante $\mathrm{C} \alpha / \mathrm{Cc}$ definida para alguns solos, é possível obter o C $\alpha$ a partir dos valores de Cc (Mesri e Choi, 1985).

\section{4}

\section{Instrumentação em Barragens de Aterro}

O acompanhamento do desempenho de uma estrutura pode ser realizado de várias maneiras, sendo as principais: inspeções visuais, monitoramento geodésico, levantamentos batimétricos e instrumentação de auscultação (Cruz, 1996).

Toda barragem, seja de grande ou pequeno porte, possui locais mais suscetíveis a problemas geotécnicos. Seja na fundação devido a anomalias geológicas ou mesmo em áreas de contato entre diferentes materiais. (Silveira, 2006).

Um dos objetivos da instrumentação em barragem é verificar as hipóteses de projeto para avaliar se os critérios utilizados foram adequados, esta análise serve para acumular experiência e permitir o aprimoramento da técnica utilizada. Outro objetivo é verificar a adequação dos métodos construtivos, por exemplo, a instrumentação pode apontar a utilidade ou não de um elemento estrutural. A instrumentação deve servir, também, para verificar as condições de segurança das estruturas. Caso ocorra alguma anormalidade, a instrumentação tem a função de 
apontar o problema de modo a permitir uma intervenção a tempo a fim de prevenir acidentes (Cruz, 1996).

Os principais alvos de monitoramento em uma barragem de terra são (Kutzner, 1997):

1) Controle da movimentação da barragem por meio de levantamentos geodésicos com pontos na crista e no talude de jusante;

2) Controle da qualidade e quantidade de água que infiltra através do corpo da barragem, fundação e ombreiras.

Esse monitoramento deve ser iniciado durante a construção e mantido durante o enchimento do reservatório e operação da barragem.

Por meio do monitoramento geodésico com pontos na crista e no talude de jusante é possível detectar recalques na estrutura. O monitoramento do fluxo permite a análise das poropressões exercidas no maciço compactado e fundação e a detecção de carreamento de materiais (Kutzner, 1997).

Os principais instrumentos utilizados para monitoramento do fluxo são: medidores de nível d'água, piezômetros e medidores de vazão. A seguir serão apresentadas as principais características de cada um deles e dos marcos geodésicos.

\subsubsection{Medidores de Nível D’água}

É um instrumento bastante simples que tem por objetivo determinar a altura da linha freática na fundação ou no maciço compactado. Consiste em um furo revestido com um tubo de PVC todo perfurado envolto por material filtrante e drenante, a fim de não obstruir o furo. Próximo a superficie o furo deve ser selado para evitar infiltração de água da superficie. A Figura 2.7 ilustra um medidor de nível d'água.

A obtenção do nível d'água pode ser realizada de diversas maneiras, a mais comum é a utilização de um cabo elétrico graduado com sensores nas duas pontas. Quando o cabo toca na água o circuito elétrico é fechado e é acusado pelo sensor, neste ponto deve ser feita a leitura na extremidade superior do tubo e o nível d'água é definido subtraindo o valor da leitura da elevação da boca do furo (Cruz, 1996).

Existem também sistemas automatizados para aquisição de dados da instrumentação, para medidores de nível d'água podem ser instalados transdutores 
de pressão nos tubos. Esses transdutores transmitem a informação para um dattalogger que disponibiliza a informação em um sistema que pode fazer o registro das leituras ao longo do tempo (U.S. Army Corps of Engineering, 1995).

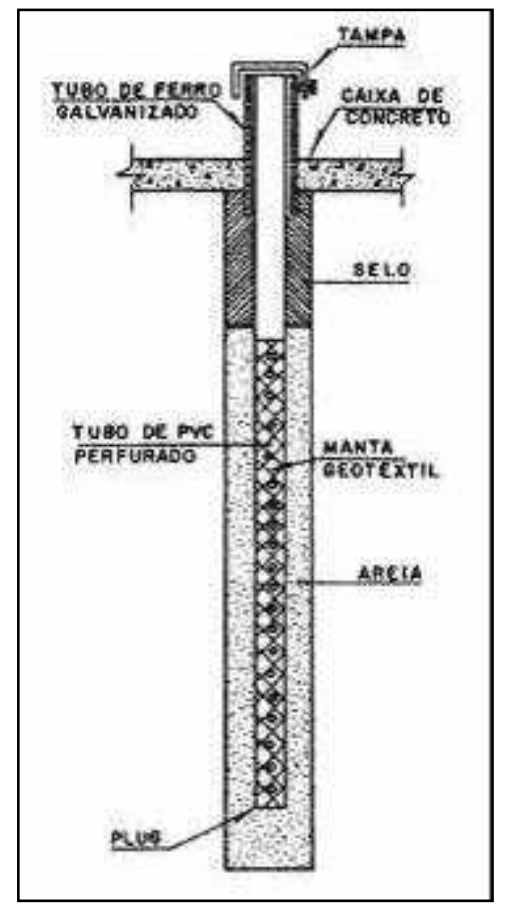

Figura 2.7 - Medidor de nível d'água (Cruz, 1996)

\subsubsection{Piezômetros standpipe}

O piezômetro standpipe funciona, na prática, de maneira semelhante ao medidor de nível d'água. A diferença está no comprimento do furo e do trecho drenante, no piezômetro o PVC é perfurado apenas na região a ser monitorada, sendo o restante do furo selado para impedir a entrada de água. A leitura é feita de maneira semelhante ao medidor de nível d'água. A Figura 2.8 ilustra um piezômetro do tipo standpipe (Cruz, 1996).

Quando o teor de umidade próximo ao instrumento permanece constante, o fluxo ou volume de água necessário para estabilizar a medição realizada será em função da permeabilidade do solo, das dimensões do instrumento e da pressão hidrostática. Existe um tempo necessário para que a água entre ou saia do instrumento e estabilize, esse tempo pode ser reduzido diminuindo o diâmetro do tubo e aumentando a área de entrada/saída da água (Hvorslev, 1951). 


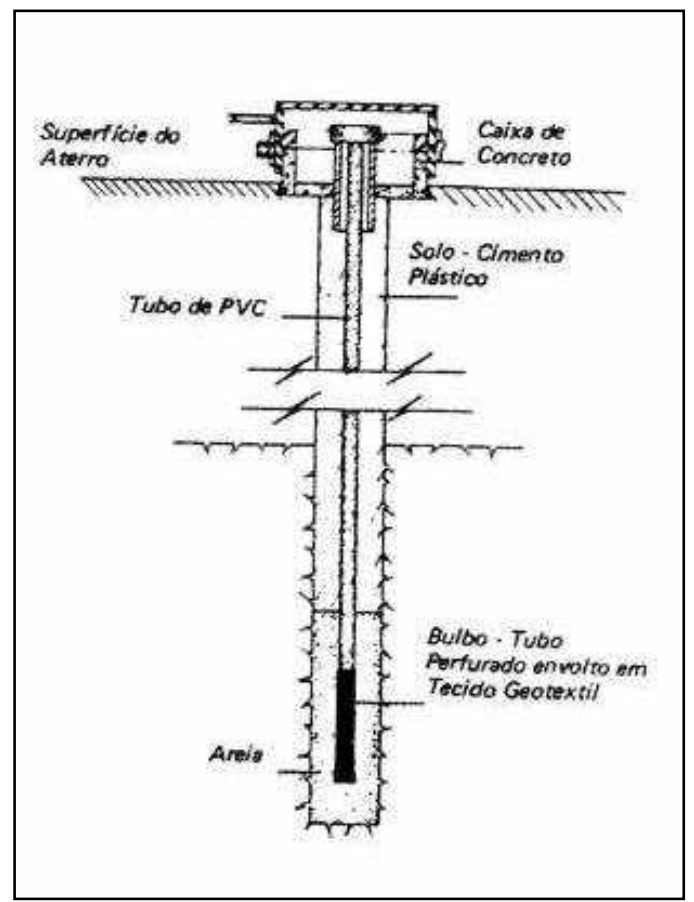

Figura 2.8 - Piezômetro standpipe (Cruz, 1996)

\subsubsection{Medidores de Vazão}

Tem por objetivo determinar a vazão de água que infiltra pelo maciço compactado ou pela fundação. Pode ser instalado em canaletas de drenagem e em drenos de fundação (Cruz, 1996).

A medição de vazões é ferramenta importante para observação de erosão interna por meio da inspeção nas características da água que chega ao medidor de vazão. A presença de materiais sólidos carreados pelas águas de drenagem pode indicar a ocorrência de pipping. Desde que detectado esse mecanismo de ruptura com antecedência, é possível tomar providências e evitar acidentes.

Existem diversos tipos de medidores de vazão, entre eles o medidor triangular, que consiste em uma placa metálica com uma passagem em forma de $\mathrm{V}$ instalada no final de um canal. Quando o fluxo passa pela passagem em V é possível medir a altura da lâmina d'água e determinar a vazão (Silveira, 2006). A Figura 2.9 mostra um dos medidores triangulares de Itaipu.

Outra forma bastante simples de realizar a medição de vazões é a execução da uma pequena barreira no canal onde ocorre o fluxo e instalação de um tubo a certa altura. As leituras podem ser feitas com um recipiente graduado para coleta da água e com um cronômetro. A vazão é determinada a partir do volume coletado 
no dado intervalo de tempo (Silveira, 2006). A Figura 2.10 mostra um tubo utilizado para medição de vazão em Itaipu.

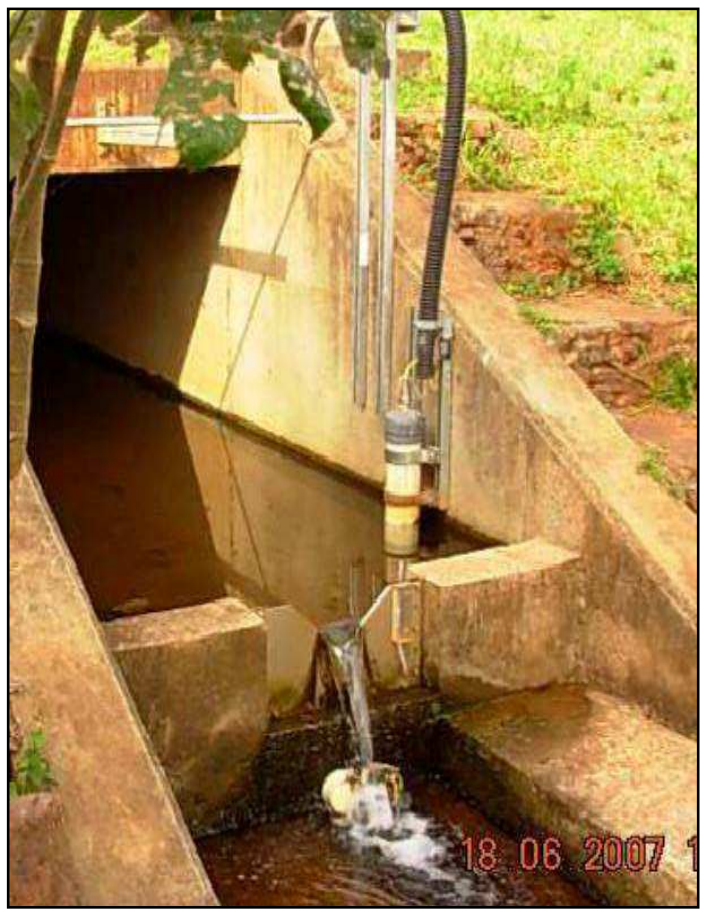

Figura 2.9 - Medidor de placa triangular (Thá, 2007)

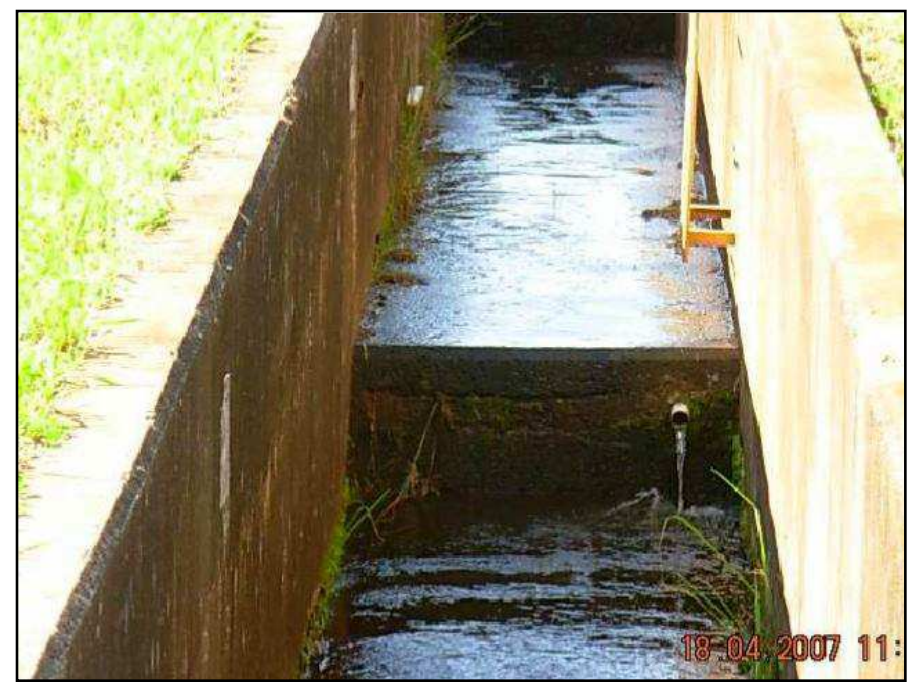

Figura 2.10 - Tubo para medição de vazão (Thá, 2007)

\subsubsection{Marcos de Referência}

A utilização dos marcos de referência é uma das técnicas mais simples e antiga utilizadas para observar os deslocamentos verticais e horizontais da barragem. Para registrar os deslocamentos na barragem é necessária uma estação topográfica próxima à ombreira, com um referencial fixo. Assim, os deslocamentos 
verticais são determinados por meio de nivelamentos de precisão e os deslocamentos horizontais por meio de triangulações ou colimações geodésicas (Silveira, 2006).

\section{5}

\section{Método dos Elementos Finitos}

O Método dos Elementos Finitos é um procedimento numérico aplicado para análises de estruturas contínuas, originou-se com a análise de tensões e hoje é utilizado para análise de transferências de calor, fluxo de fluídos, campos elétricos, magnéticos, entre outros. O método consiste em discretizar uma estrutura em pequenos elementos com geometria simples e, portanto, de mais fácil análise (Cook et al., 1989). Posteriormente, esses pequenos elementos são reconectados para representar o comportamento da estrutura como um todo.

O poder computacional disponível na atualidade resultou no desenvolvimento de diversos softwares avançados para aplicação do método dos elementos finitos na engenharia. Os softwares, em geral, funcionam como poderosa ferramenta de cálculo, entretanto, a obtenção de resultados coerentes e representativos dependem da boa modelagem do usuário (GEO-SLOPE International, 2012).

O programa GeoSlope contempla um conjunto de pacotes que permitem avaliar o desempenho de barragens e diques, entre eles o SEEP/W, SLOPE/W e SIGMA/W que serão utilizados neste trabalho. O SLOPE/W é o único que não utiliza o método dos elementos finitos, as análises de estabilidade são realizadas por métodos de equilíbrio limite.

$\mathrm{O}$ SEEP/W, que realiza os cálculos relacionados ao fluxo, é baseado na lei de Darcy e pode considerar o solo todo saturado ou parcialmente saturado. A diferença básica está no valor da permeabilidade que deixa de ser constante no caso de saturação parcial e passa a variar em função do teor de umidade.

A equação diferencial que governa a infiltração bidimensional em cada elemento é expressa por:

$$
\frac{\partial}{\partial x}\left(k_{x} \frac{\partial H}{\partial x}\right)+\frac{\partial}{\partial y}\left(k_{y} \frac{\partial H}{\partial y}\right)+Q=\frac{\partial \theta}{\partial t}
$$


Sendo:

$\mathrm{H}$ - Carga total;

$\mathrm{k}_{\mathrm{x}}$ - Permeabilidade na direção $\mathrm{x}$;

$\mathrm{k}_{\mathrm{y}}$ - Permeabilidade na direção $\mathrm{y}$;

Q - Condição de fluxo pré-estabelecida;

$\theta$ - teor de umidade volumétrico;

$\mathrm{t}$ - tempo.

Em condição de fluxo permanente, não há variação do teor de umidade em função do tempo e, então, o lado esquerdo da equação é igualado a zero.

O SIGMA/W pode resolver problemas de deformação considerando apenas as condições de tensão-deformação ou realizando a análise acoplada com a dissipação de poropressões. $\mathrm{Na}$ análise acoplada são resolvidas três equações simultaneamente para cada nó da malha, duas de equilíbrio (deslocamentos em duas direções) e a terceira de continuidade (fluxo). A forma do programa resolver as equações se assemelha a proposta de adensamento de Biot descrita no Item 2.3.1 (GEO-SLOPE International, 2013). 


\section{3 \\ Barragem de Terra da Margem Esquerda de Itaipu}

A barragem de terra da margem esquerda (BTME) de Itaipu faz o fechamento entre a barragem de enrocamento e o terreno natural na ombreira esquerda, fechando o conjunto de estruturas que constituem a represa à esquerda do Rio Paraná. A Figura 3.1 mostra uma foto panorâmica da BTME próximo à ombreira.

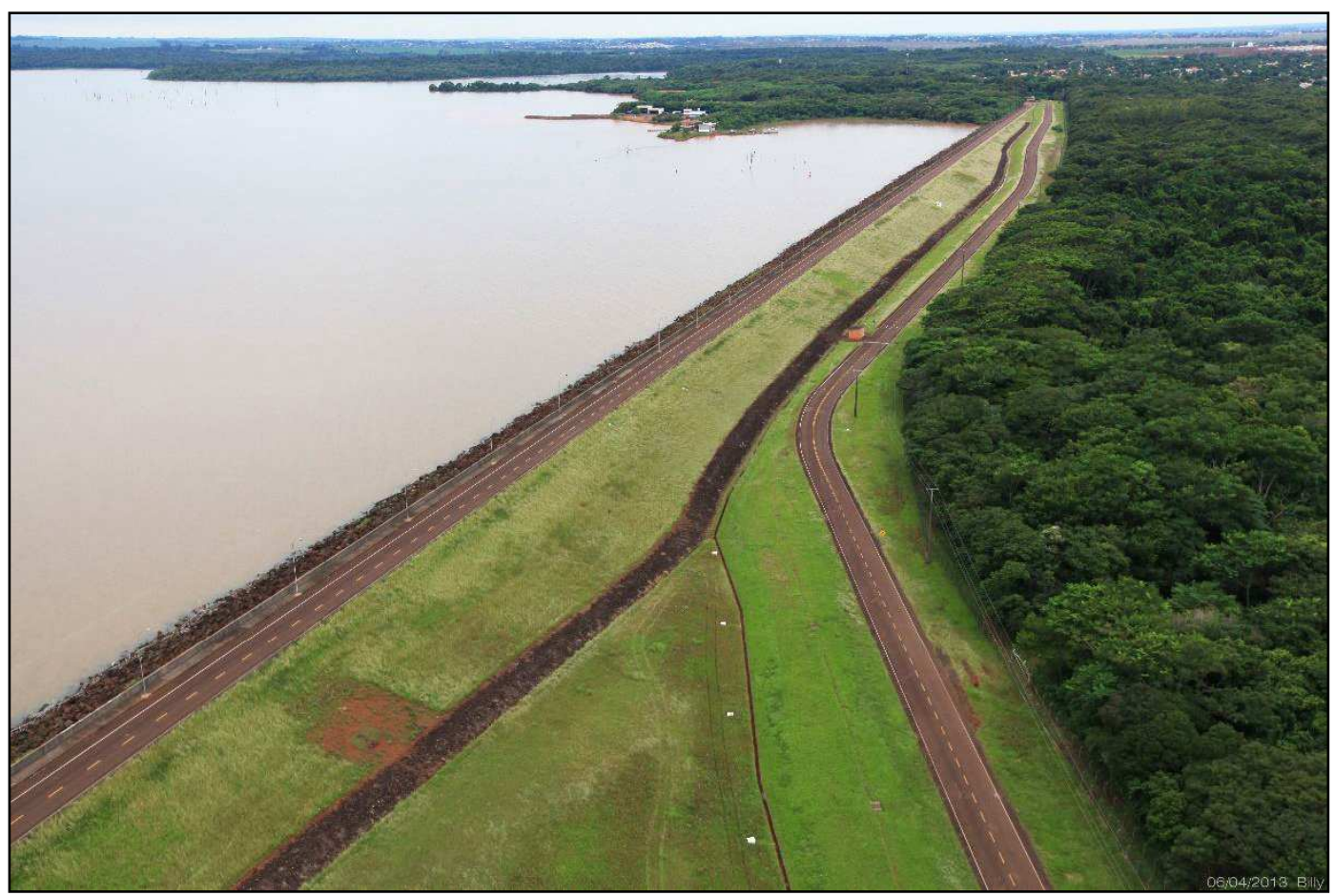

Figura 3.1 - Barragem de Terra da Margem Esquerda (Itaipu Binacional)

A primeira etapa da construção da BTME ocorreu entre junho de 1977 e maio de 1978 com a construção das bermas, a fim de acelerar o adensamento do terreno de fundação. A princípio foram feitas com uma geometria conservadora e posteriormente corrigida.

As obras do maciço compactado começaram efetivamente em janeiro de 1979 com a construção do trecho de transição entre a BTME e a barragem de enrocamento. Em outubro de 1979 foi iniciada a construção do trecho da BTME com altura superior a $10 \mathrm{~m}$ (trecho com bermas) e em outubro de 1980 a construção do trecho com altura inferior a $10 \mathrm{~m}$ (trecho sem bermas). As obras do maciço 
compactado foram concluídas em junho de 1982. A Figura 3.2 é uma foto da construção do último trecho (IECO e ELC, 1995).

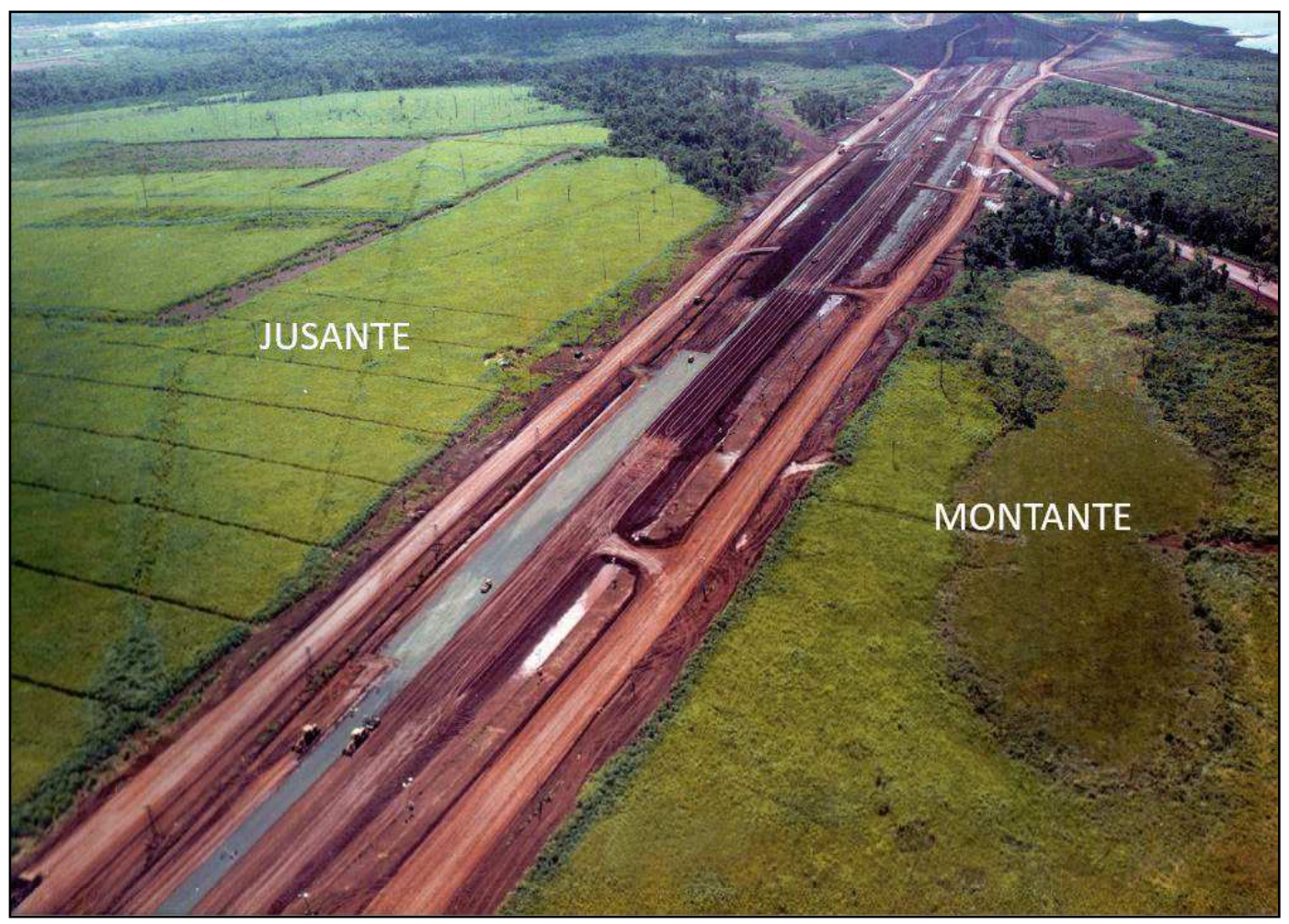

Figura 3.2 - BTME durante construção em 1982 (adaptado de Itaipu Binacional, 2009)

\section{1 \\ Características Geométricas}

$\mathrm{O}$ projeto da BTME abrange a barragem de terra propriamente dita e a barragem de transição com a barragem de enrocamento. $O$ trecho possui um eixo em forma de arco sem inflexões. A barragem de terra possui $1.989,33 \mathrm{~m}$ de comprimento e a zona de transição $305 \mathrm{~m}$, juntas totalizam $2.293,33 \mathrm{~m}$.

A BTME possui menor altura na ombreira esquerda, onde encontra o terreno na cota $225 \mathrm{~m}$, e atinge altura máxima na divisa com a barragem de enrocamento, onde chega a $32 \mathrm{~m}$. Por possuir variação de altura considerável, a BTME foi dividida em duas partes: uma com altura menor que $10 \mathrm{~m}$ (trecho I) e outra com altura entre 10 a $30 \mathrm{~m}$ (trecho II). O desenho dessas seções é mostrado na Figura 3.3 . 


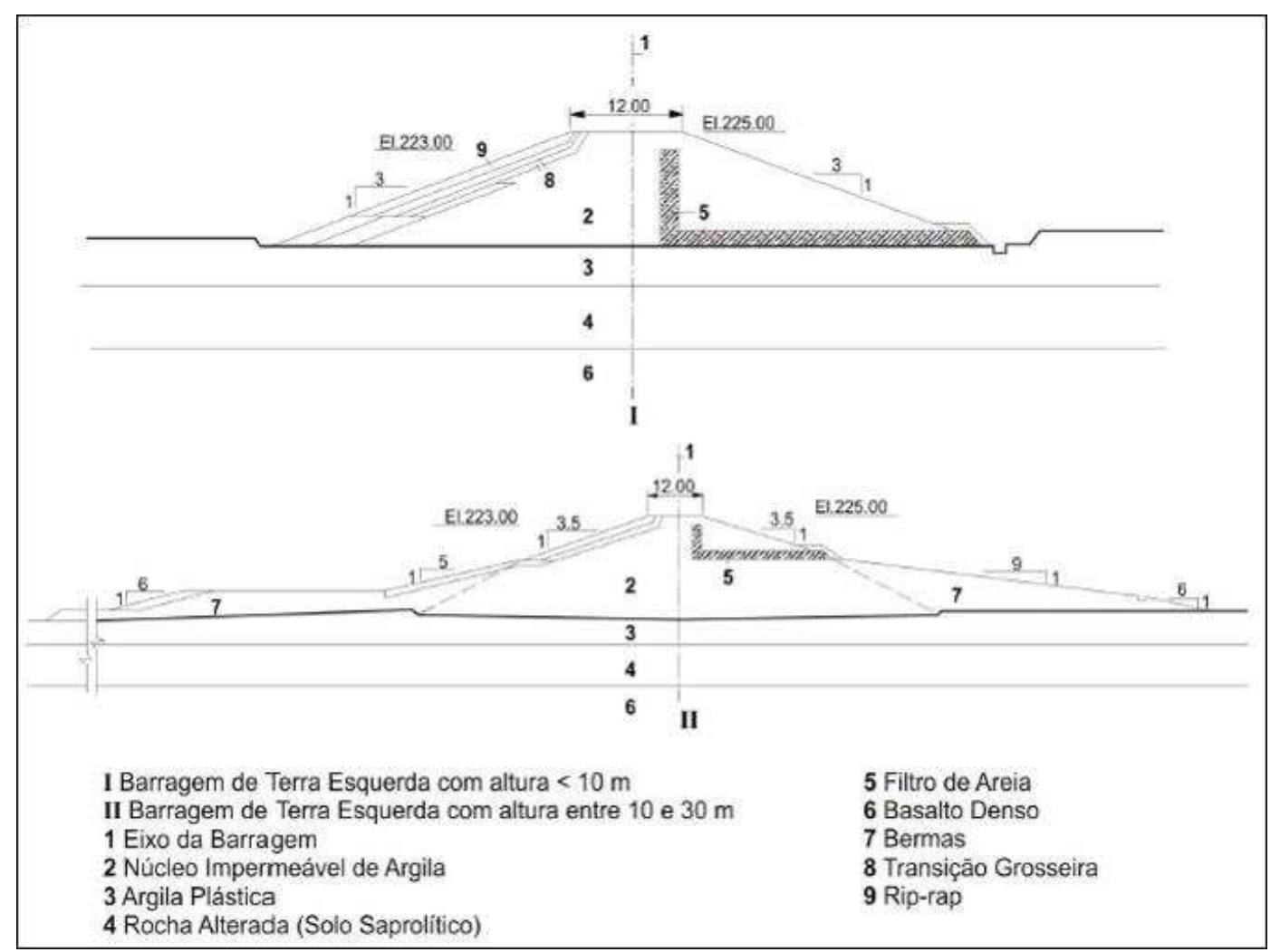

Figura 3.3 - Seções típicas da BTME (Itaipu Binacional, 2009)

O Trecho I inicia na ombreira esquerda e possui $1.356,50 \mathrm{~m}$ de comprimento, possui seção transversal com taludes uniformes em ambos os lados com 1V:3H. Em seguida se inicia o Trecho II que se estende por $482,30 \mathrm{~m}$ e possui uma seção central homogênea de argila. Os taludes são de $1 \mathrm{~V}: 3,5 \mathrm{H}$ da crista até meia altura e de $1 \mathrm{~V}: 2 \mathrm{H}$ até a fundação,

No trecho que a altura varia de 10 a $30 \mathrm{~m}$, existem bermas que iniciam na mudança de inclinação do talude principal. A montante a berma inicia com $1 \mathrm{~V}: 5 \mathrm{H}$ e em seguida passa para $1 \mathrm{~V}: 6 \mathrm{H}$ até ficar a 2 metros do terreno natural, encontrandoo com $1 \mathrm{~V}: 2 \mathrm{H}$. A jusante a berma inicia com $1 \mathrm{~V}: 9 \mathrm{H}$ e em seguida muda para $1 \mathrm{~V}: 6 \mathrm{H}$ até interceptar o terreno natural.

$\mathrm{Na}$ transição entre os dois trechos, a seção do Trecho II se transforma gradualmente na seção simples do trecho I, as bermas vão diminuindo até chegar a zero na Est. $128+80$ (Itaipu Binacional, 2009). 


\section{2}

\section{Características Geotécnicas}

\subsection{1 \\ Maciço Compactado}

A princípio estava prevista utilização de argila de duas áreas de empréstimo para construção do maciço da BTME, sendo uma argila arenosa e outra argila plástica, provenientes respectivamente das áreas de empréstimo Santa Isabel, localizada a $5.300 \mathrm{~m}$ da barragem, e Pomba-Quê a $500 \mathrm{~m}$.

$\mathrm{O}$ uso da argila plástica estava limitado ao trecho com altura inferior a $10 \mathrm{~m}$, pois, possuía elevada umidade natural. Durante o andamento das obras notou-se que o desmatamento e a raspagem das áreas de empréstimo provocaram diminuição na umidade natural e pouco antes do início da construção do maciço da BTME, em setembro de 1979, foi determinada a utilização de argila plástica para todo o maciço, sendo assim toda argila utilizada foi da área de empréstimo Pomba-Quê (Themag Engenharia e Grupo Alto Paraná, 1990).

Durante a construção do maciço existia um controle de qualidade sobre o método construtivo e compactação que exercia as seguintes atividades: liberação do solo de acordo com a faixa de desvio de umidade especificada, controle de espalhamento e homogeneização, verificação da espessura da camada solta, controle do número de passadas do rolo compactador, verificação da espessura compactada e execução de ensaio para verificar parâmetros de compactação.

A camada solta tinha espessura de $15 \mathrm{~cm}$ e a compactação era realizada com 6 passadas do rolo. Após a compactação, a camada deveria ter $10 \mathrm{~cm}$ de espessura. Era realizado, em média, um ensaio de controle de compactação pelo método Hilf para $470 \mathrm{~m}^{3}$ de maciço compactado e a cada cinco ensaios de Hilf era coletado material, próximo do local, para execução do ensaio de compactação Proctor Normal.

Além dos ensaios in situ, durante a construção foram coletados dezoito blocos indeformados com $30 \mathrm{~cm}$ de aresta. Tais blocos foram retirados da camada compactada e enviados ao Laboratório Central de Itaipu, onde o material obtido da talhagem era utilizado para ensaios de caracterização e de compactação Proctor e a amostra em si era usada para realização de ensaios especiais (IECO e ELC, 1982). 


\section{Compactação e Caracterização}

Em projeto foi especificado um limite de desvio de umidade e grau de compactação, com relação ao Proctor Normal, de $2 \%$ abaixo ou acima da umidade ótima e GC $\geq 95 \%$. Para o controle de compactação pelo método Hilf foi admitido $3 \%$ abaixo a $1 \%$ acima da ótima e GC $\geq 97 \%$. Em campo, o controle de compactação admitiu até $15 \%$ dos valores com variação de umidade entre $1 \%$ e $2 \%$ úmido e dos valores de GC entre 95\% e 97\%.

Considerando todos os ensaios de compactação, obteve-se uma média global do desvio de umidade de 0,38\% abaixo da umidade ótima e GC de 99,63\%. A espessura média da camada compactada foi de $10,2 \mathrm{~cm}$. A porcentagem de camadas recompactadas em relação ao total de camadas foi de 3,6\% (IECO e ELC, 1982).

Os índices fisicos da argila são mostrados na Tabela 3.1.

Tabela 3.1 - Caracterização e índices físicos da argila do maciço compactado (IECO e ELC, 1992)

\begin{tabular}{cc}
\hline Fração de argila $(\%<2 \mu)$ & 79 \\
Densidade dos sólidos & 2,82 \\
LL (\%) & 59 \\
IP $(\%)$ & 33 \\
Umidade ótima $(\%)$ & 29,3 \\
Peso esp. seco $\left(\mathrm{g} / \mathrm{cm}^{3}\right)$ & 1,47 \\
Peso esp. saturado $\left(\mathrm{g} / \mathrm{cm}^{3}\right)$ & 1,94 \\
Índice de vazios & 0,90 \\
Porosidade $(\%)$ & 47,4 \\
\hline
\end{tabular}

\section{Permeabilidade}

Durante o período construtivo, a permeabilidade do solo foi determinada em três tipos de ensaio realizados: permeâmetro convencional de carga variável, compressão triaxial e adensamento.

Os ensaios com permeâmetro de carga variável foram realizados com corpos de provas cilíndricos com 10,2 cm de diâmetro e de altura. Foi realizado ensaio em duas direções considerando que há anisotropia da permeabilidade. A permeabilidade horizontal ficou, em média, três vezes maior que a vertical. Foram 
realizados 18 ensaios e o resumo dos valores é mostrado na Tabela 3.2 (IECO e ELC, 1982).

Tabela 3.2 - Valores de permeabilidade obtidos no permeâmetro de carga variável (IECO e ELC, 1982)

\begin{tabular}{ccc}
\hline & $\begin{array}{c}\text { Permeab. Horiz. } \\
(\mathrm{cm} / \mathrm{s})\end{array}$ & $\begin{array}{c}\text { Permeab. Vert. } \\
(\mathrm{cm} / \mathrm{s})\end{array}$ \\
\hline Valor Máximo & $3,4 \times 10^{-6}$ & $5,3 \times 10^{-7}$ \\
Valor Mínimo & $4,7 \times 10^{-8}$ & $2,4 \times 10^{-8}$ \\
Média & $3,4 \times 10^{-7}$ & $1,3 \times 10^{-7}$ \\
\hline
\end{tabular}

Para os ensaios com câmaras de compressão triaxial, eram moldados corpos de prova cilíndricos medindo cerca de $10,2 \mathrm{~cm}$ de diâmetro e 5,0 cm de altura. A amostra era saturada por contrapressão e adensada isotropicamente para 50, 100, $200,300,400$ e $500 \mathrm{kPa}$. O ensaio ocorria com cargas constantes e ao final de cada estágio de adensamento era determinado o coeficiente de permeabilidade.

As permeabilidades horizontais para esse tipo de ensaio variaram entre $2 \mathrm{x}$ $10^{-7} \mathrm{~cm} / \mathrm{s}$, com $50 \mathrm{kPa}$ de pressão confinante efetiva, e $6 \times 10^{-9} \mathrm{~cm} / \mathrm{s}$, com $500 \mathrm{kPa}$ de pressão confinante efetiva. As permeabilidades verticais variaram entre $4 \times 10^{-8}$ $\mathrm{cm} / \mathrm{s}$ com $50 \mathrm{kPa}$ de pressão confinante e $3,5 \times 10^{-9}$ com $500 \mathrm{kPa}$ de pressão confinante efetiva, mostrando que a permeabilidade horizontal tende a reduzir em maior escala com o adensamento.

No ensaio de adensamento foi determinada a permeabilidade vertical das amostras, os dados foram tratados estatisticamente e o valor variou de $2 \times 10^{-7} \mathrm{~cm} / \mathrm{s}$ com $320 \mathrm{kPa}$ de pressão vertical a 2 x 10-9 $\mathrm{cm} / \mathrm{s}$ com $1000 \mathrm{kPa}$ de pressão vertical, mostrando a considerável redução da permeabilidade com o adensamento (IECO e ELC, 1982).

\section{Resistência ao Cisalhamento}

As amostras indeformadas coletadas do maciço eram utilizadas para diversos ensaios, entre eles o ensaio de compressão triaxial. Foram executados ensaios nãoconsolidados e não-drenados (UU), consolidados e não-drenados sem saturação $(\mathrm{CU})$, consolidados e não-drenados saturados $\left(\mathrm{CU}_{\text {sat }}\right)$ e consolidados e drenados $(\mathrm{CD})$. 
As dimensões dos corpos de prova foram de 3,6 cm de diâmetro por $8,0 \mathrm{~cm}$ de altura ou $3,8 \mathrm{~cm}$ por $7,6 \mathrm{~cm}$. Os ensaios $\mathrm{UU}, \mathrm{CU}$ e $\mathrm{CD}$ eram cisalhados para tensão de confinamento de 100, 300 e $600 \mathrm{kPa}$ e os ensaios $\mathrm{CU}_{\text {sat }}$ para 100, $200 \mathrm{e}$ $400 \mathrm{kPa}$. Para os ensaios não-drenados, era realizada medição de poropressão.

Os ensaios ocorriam com deformação controlada, nas seguintes velocidades: $0,03 \mathrm{~mm} / \mathrm{min}$ para os ensaios UU, CU e $\mathrm{CU}_{\text {sat }}$ e 0,0007 ou $0,0008 \mathrm{~mm} / \mathrm{min}$ nos ensaios CD.

A resistência do solo em tensões totais é obtida nos ensaios UU, os resultados mostram que a resistência para uma dada pressão confinante é função da umidade da amostra. Esses resultados foram utilizados para cálculo de estabilidade dos taludes na condição de fim de construção, que é uma condição considerada não adensada e não drenada devido à velocidade de aplicação das cargas.

Os parâmetros obtidos pelo ensaio $\mathrm{CD}$, que representam uma condição adensada e drenada, são usados para os cálculos de estabilidade a longo prazo enquanto os parâmetros do ensaio $\mathrm{CU}_{\text {sat }}$, que representam uma condição adensada e não drenada, são usados para os cálculos de estabilidade em caso de rebaixamento rápido, em que não há tempo para drenagem e dissipação das poropressões.

Para cada tipo de ensaio foi montado um gráfico p' x q', foi adotado como critério de ruptura o acréscimo máximo da tensão desviadora $\left(\sigma_{1}-\sigma_{3}\right)$. As tensões efetivas desse gráfico foram correlacionadas estatisticamente por meio de uma regressão linear que possibilitou a determinação dos valores de a' e $\alpha^{\prime}$, que por sua vez possibilitaram o cálculo dos parâmetros de resistência c' e $\Phi$ '. Os gráficos estão no Anexo I e o resumo dos dados são mostrados na Tabela 3.3 (IECO e ELC, 1982).

Tabela 3.3 - Correlações para obtenção dos parâmetros de resistência (IECO e ELC, 1982)

\begin{tabular}{ccccc}
\hline $\begin{array}{c}\text { Tipo de } \\
\text { ensaio }\end{array}$ & $\begin{array}{c}\text { Número de } \\
\text { ensaios }\end{array}$ & $\begin{array}{c}\text { Coeficiente } \\
\text { de correlação }\end{array}$ & c' $(\mathrm{kPa})$ & $\Phi^{\prime}\left({ }^{\mathrm{o}}\right)$ \\
\hline $\mathrm{UU}$ & 48 & 0,97 & 82 & 25,5 \\
$\mathrm{CD}$ & 49 & 0,99 & 54 & 27,4 \\
$\mathrm{CU}$ & 21 & 0,99 & 52 & 27,7 \\
$\mathrm{CU}_{\text {sat }}$ & 45 & 0,99 & 36 & 29,3 \\
\hline
\end{tabular}




\section{Adensamento}

Os ensaios de adensamento, realizados durante o período construtivo, utilizaram anel fixo e corpos de prova cilíndricos medindo $11,26 \mathrm{~cm}$ de diâmetro e $3,81 \mathrm{~cm}$ de altura. $\mathrm{O}$ ensaio ocorria com a amostra inundada desde o início, em estágios de carregamento de $24 \mathrm{~h}$ e de descarregamento de $2 \mathrm{~h}$.

$\mathrm{O}$ coeficiente de adensamento foi obtido pelo processo de Casagrande e, dentre os 18 ensaios, os limites ficaram entre $9,5 \times 10^{-4} \mathrm{~cm}^{2} / \mathrm{s}$ e $8,6 \times 10^{-3} \mathrm{~cm}^{2} / \mathrm{s}$. A pressão de pré-adensamento, calculada pelo processo de Pacheco Silva, ficou entre 140 a $700 \mathrm{kPa}$. O índice de compressão entre 0,12 e 0,20 e o índice de recompressão foi praticamente constante e igual a 0,02 . As curvas de adensamento podem ser vistas no Anexo II (IECO e ELC, 1982).

\subsection{2}

\section{Fundação}

Itaipu localiza-se no contexto geológico da Bacia do Paraná, caracterizada por rochas extrusivas basálticas da Serra Geral, os derrames são cobertos por um perfil de meteorização. A BTME foi construída nas proximidades dos vales de dois rios, Pomba-quê e Bela vista (IECO e ELC, 1977).

No período de investigação geotécnica foi realizada uma campanha de sondagens rotativas e a percussão, complementada pela abertura de poços de inspeção para coleta de amostras deformadas e indeformadas e inspeção visual.

As amostras indeformadas eram parafinadas e embaladas em caixas de madeira dentro do próprio poço e enviadas para o Laboratório de Solos da Centrais Elétricas de São Paulo (CESP) em Itha Solteira - SP, onde eram realizados ensaios para determinação das características do solo e parâmetros de resistência, deformabilidade e permeabilidade (CESP, 1975, 1976a, 1976b).

Por meio das sondagens constatou-se que a espessura média de solo no local é de $16 \mathrm{~m}$, sendo constituída por três camadas: superior, composto de argila plástica vermelha (solo maduro), intermediário, composto por silte argiloso amarelo, e inferior, composto por saprolito de basalto (solo jovem). Esta camada de saprolito está presente em toda a área da barragem com espessura variável, mas sempre suficiente para controlar o comportamento da fundação. 
O derrame imediatamente abaixo do solo é denominado Derrame E, este apresenta boa qualidade nos parâmetros geomecânicos. O índice de qualidade da rocha (Rock Quality Designation - RQD) é elevado e o grau de fraturamento é baixo. A permeabilidade é baixa devido a existência de minerais que impermeabilizam as juntas. Foram realizados ensaios de perda d'água e concluiuse que a possibilidade de infiltração através do maciço rochoso é nula devido à boa qualidade geomecânica que possui (IECO e ELC, 1977).

Entre o saprolito e o basalto são existe uma camada de rocha alterada com espessura variável. Tal camada não foi considerada por não se dispor de dados suficientes sobre ela, estudos anteriores mostraram que a influência da consideração dessa camada é muito pequena (Thá, 2007).

Durante a investigação foram identificados dez derrames basálticos com espessuras variáveis entre 20 e $65 \mathrm{~m}$, essas camadas são constituídas por uma parte inferior, composta por basalto denso, parte superior, composta por basalto vesículoamigdaloidal, e brecha (IECO e ELC, 1977).

A Figura 3.4 mostra uma seção geológica típica do local de Itaipu.

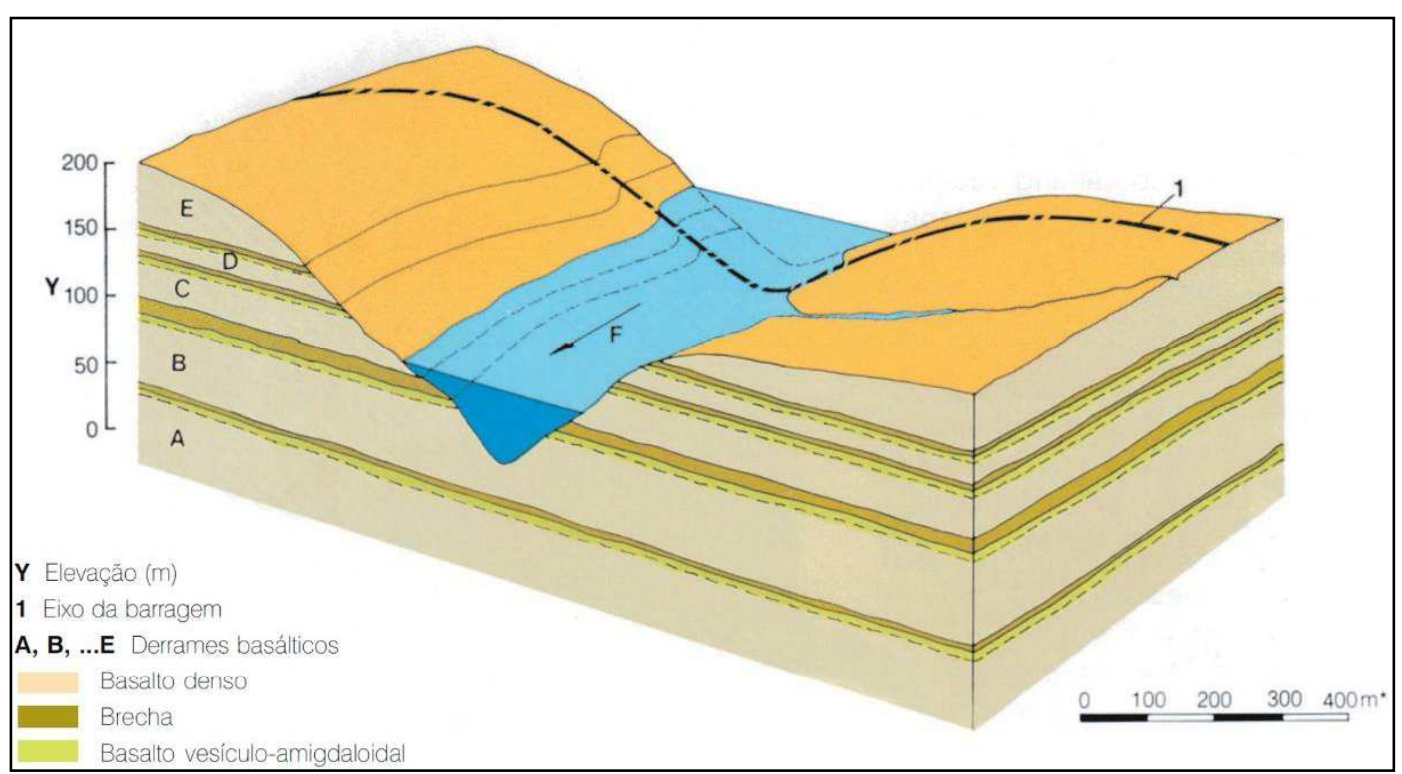

Figura 3.4 - Perfil geológico da região de Itaipu (Itaipu Binacional, 2009)

\section{Geologia e Caracterização}

O material denominado argila vermelha possui porcentagens elevadas de fração de argila, aproximadamente 10 a $12 \%$ de silte e o restante de areia. É a camada de solo mais madura, onde a meteorização se mostra mais avançada. Possui coloração vermelha a marrom escuro e a espessura varia entre 3 e $11 \mathrm{~m}$. 
A camada intermediária constitui uma transição entre a argila vermelha e o saprolito, caracterizada pelo silte argiloso, possui coloração amarela e, granulometricamente, neste horizonte diminui-se consideravelmente a fração argilosa e aumenta a fração arenosa. Possui espessura média de $3 \mathrm{~m}$ e o máximo observado chega a $6 \mathrm{~m}$.

O saprolito, também classificado como basalto decomposto, ocorre no horizonte inferior justamente no contato com a rocha alterada, possui estruturas herdadas da rocha matriz. É considerado o solo mais jovem e por isso possui permeabilidade maior que o solo maduro, já que as fraturas e diaclases da rocha se conservam transferindo ao solo planos de fraqueza. Possui coloração vermelha com manchas cinzas e esbranquiçadas e alguns traços azulados nas faces dos planos de fraturas. Possui espessura entre $1 \mathrm{e} 17 \mathrm{~m}$.

A Figura 3.5 mostra um perfil típico do solo na região de Itaipu.

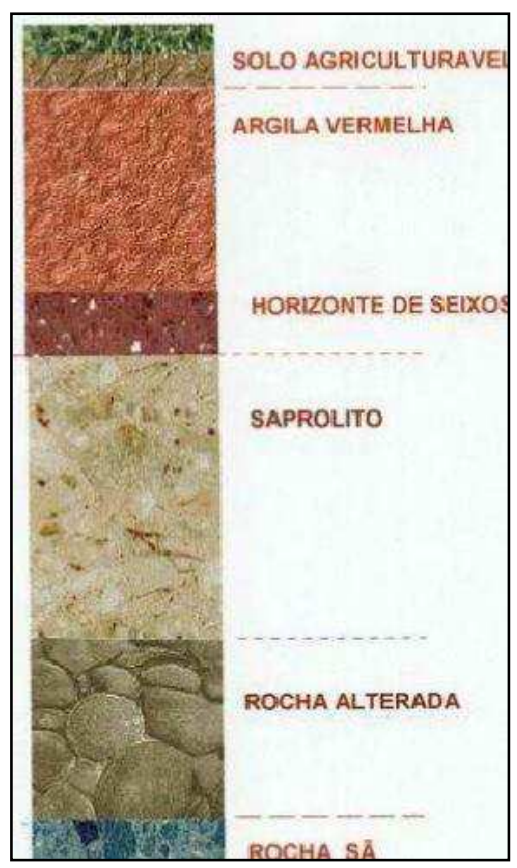

Figura 3.5 - Perfil típico do solo na região de Itaipu (Thá, 2007)

O modelo geotécnico dividiu a camada de solo em argila e saprolito, todos os ensaios são feitos classificando o material em uma dessas classes. Na Tabela 3.4 são mostrados os índices físicos desses (IECO e ELC, 1992). 
Tabela 3.4 - Caracterização e índices físicos do solo de fundação (IECO e ELC, 1992)

\begin{tabular}{ccc}
\hline & Argila & Saprolito \\
\hline Fração de argila $(\%<2 \mu)$ & 68 & 42 \\
Densidade dos sólidos & 2,95 & 3,03 \\
LL (\%) & 63 & 73 \\
IP (\%) & 38 & 27 \\
Umidade natural $(\%)$ & 28 & 46 \\
Peso esp. aparente natural $\left(\mathrm{g} / \mathrm{cm}^{3}\right)$ & 1,23 & 1,22 \\
Peso esp. do solo saturado $\left(\mathrm{g} / \mathrm{cm}^{3}\right)$ & 1,82 & 1,84 \\
Índice de vazios & 1,489 & 1,621 \\
Porosidade $(\%)$ & 59,8 & 68,8 \\
\hline
\end{tabular}

\section{Permeabilidade}

$\mathrm{Na}$ época de investigação foram realizados três tipos de ensaio que forneceram valores de permeabilidade: permeâmetro convencional de carga variável, compressão triaxial e adensamento.

Os coeficientes de permeabilidade obtidos durante a execução dos ensaios de adensamento em corpos de provas indeformados, mostraram uma relação inversamente proporcional com a tensão vertical aplicada, o comportamento ocorre tanto nos solos argilosos como no saprolito. Também foram realizados ensaios de permeabilidade com carga variável em câmara triaxial, o comportamento do solo foi semelhante (IECO e ELC, 1992, 1977).

Os valores de coeficiente de permeabilidade efetivamente utilizados nas análises de fluxo, foram os obtidos pelos permeâmetros convencionais com carga variável. Para esses ensaios foram moldados corpos de prova na vertical e na horizontal, os valores ficaram próximos e o solo foi considerado isotrópico. Os valores de permeabilidade obtidos com o tratamento estatístico dos resultados foram: para a argila $\mathrm{k}=4,4 \times 10^{-5} \mathrm{~cm} / \mathrm{s}$ e para o saprolito $\mathrm{k}=2,5 \times 10^{-3} \mathrm{~cm} / \mathrm{s}$ (IECO e ELC, 1977).

A estrutura porosa da camada de saprolito reflete em sua permeabilidade, o que faz dessa camada um dreno natural, de maneira que a percolação preferencial através da barragem ocorra por essa camada. 


\section{Resistência ao Cisalhamento}

As amostras indeformadas coletadas no período de investigação e enviadas para o Laboratório de Solos da CESP em Ilha Solteira - SP foram ensaiadas com compressão triaxial UU, $\mathrm{CU}$ e $\mathrm{CD}$. Os corpos de prova eram moldados usualmente com 2" de diâmetro por 4" de altura ou 4" de diâmetro por 8" de altura.

As amostras foram adensadas isotropicamente com $\mathrm{K}_{0}=0,5$ para pressões de confinamento que variaram de $50 \mathrm{a} 800 \mathrm{kPa}$, de acordo com local de coleta da mesma.

Os parâmetros obtidos dos ensaios UU com medição de poropressão, foram usados na análise de estabilidade para condição de fim de construção, onde não existe condição de adensamento ou drenagem. Para as análises de estabilidade na condição de fluxo permanente a longo prazo, são utilizados os parâmetros obtidos pelo ensaio $\mathrm{CD}$ e os parâmetros obtidos no ensaio $\mathrm{CU}$, com corpo de prova adensado e carregamento não drenado, foram utilizados nas análises de rebaixamento rápido (CESP, 1975, 1976a, 1976b).

A Tabela 3.5 resume os parâmetros de resistência obtidos por cada tipo de ensaio para os dois materiais de fundação.

Tabela 3.5 - Parâmetros de resistência da fundação (IECO e ELC, 1992, 1977)

\begin{tabular}{ccccc}
\hline $\begin{array}{c}\text { Tipo de } \\
\text { ensaio }\end{array}$ & $\mathrm{c}^{\prime}(\mathrm{kPa})$ & $\Phi^{\prime}\left({ }^{\circ}\right)$ & $\mathrm{c}^{\prime}(\mathrm{kPa})$ & $\Phi^{\prime}\left({ }^{\circ}\right)$ \\
\hline UU & 20 & 24 & 10 & 31 \\
$\mathrm{CD}$ & 0 & 23 & 20 & 25 \\
$\mathrm{CU}$ & 10 & 25 & 20 & 25 \\
\hline
\end{tabular}

\section{Adensamento}

Os ensaios de adensamento oedométrico foram realizados em anel fixo com $11,52 \mathrm{~cm}$ de diâmetro e $3,82 \mathrm{~cm}$ de altura e incrementos de carga a cada $24 \mathrm{~h}$ e descarregamento em 2 h (CESP, 1975, 1976a, 1976b).

As pressões de pré-adensamento foram determinadas pelo método de Pacheco Silva e para a argila se obteve $\sigma_{\mathrm{p}}=181 \mathrm{kPa}$ e para o saprolito $\sigma_{\mathrm{p}}=840 \mathrm{kPa}$, valor muito superior ao incremento de peso do maciço. 
Para a argila se obteve índice de compressão igual a 0,58 e para o saprolito 0,75 , com estes valores concluiu-se que os materiais da fundação são bastante compressíveis e há predominância de recalques imediatos (IECO e ELC, 1992).

\subsection{3}

\section{Bermas, Filtros e Transições}

As bermas foram construídas com materiais variados como argilas arenosas, argilas plásticas e saprolito, sem controle de compactação. Os materiais não passaram por ensaios e desta forma o projeto foi realizado com uma estimativa conservadora dos parâmetros de resistência e permeabilidade desses materiais. Para a análise de estabilidade e dimensionamento do sistema de drenagem, foi adotado coeficiente de permeabilidade vertical igual ao horizontal, sendo $\mathrm{Kv}=\mathrm{Kh}=10^{-5}$ $\mathrm{cm} / \mathrm{s}$, parâmetros de resistência em termos de tensões totais $\mathrm{c}=30 \mathrm{kPa}$ e $\Phi=10^{\circ} \mathrm{e}$ em termos de tensões efetivas $c^{\prime}=0$ e $\Phi^{\prime}=25^{\circ}$ (IECO e ELC, 1977).

Os filtros da BTME utilizaram areia artificial, o processo envolvia trituração, peneiramento e lavagem da areia, todo processo era realizado na central de produção. Tanto para o tapete drenante como para o dreno vertical, a areia era solta com uma espessura de $25 \mathrm{~cm}$ compactada com quatro passadas de rolo compactador.

Os ensaios apontaram a permeabilidade da areia entre $8 \times 10^{-1}$ e $8 \times 10^{-2} \mathrm{~cm} / \mathrm{s}$. Para os parâmetros de resistência não foram realizados ensaios pois a camada de areia comparada ao maciço é muito pequena, foi então adotado c' $=0$ e $\Phi^{\prime}=40^{\circ}$ (IECO e ELC, 1992).

Nas transições e rip-rap foi utilizado material rochoso obtido da escavação em rocha do canal de desvio, foi observada a granulometria especificada e teve-se o cuidado com as características de desagregação do material. Não foram realizados outros ensaios para determinação de, por exemplo, resistência e massa específica (IECO e ELC, 1977). 


\section{3}

\section{Dados Hidrometeorológicos}

\subsection{1}

\section{Precipitação}

Analisando o registro histórico das precipitações médias anuais em Itaipu, mostrado na Figura 3.6, nota-se que há uma variação das chuvas ao longo dos anos, entretanto, os valores anuais mantêm-se em uma faixa de variação constante em relação à média. São picos notáveis: a cheia ocorrida em 1983, quando o reservatório estava em fase de enchimento, outra cheia ocorrida em 1998, uma seca ocorrida em 1985 e outra seca em 1999.

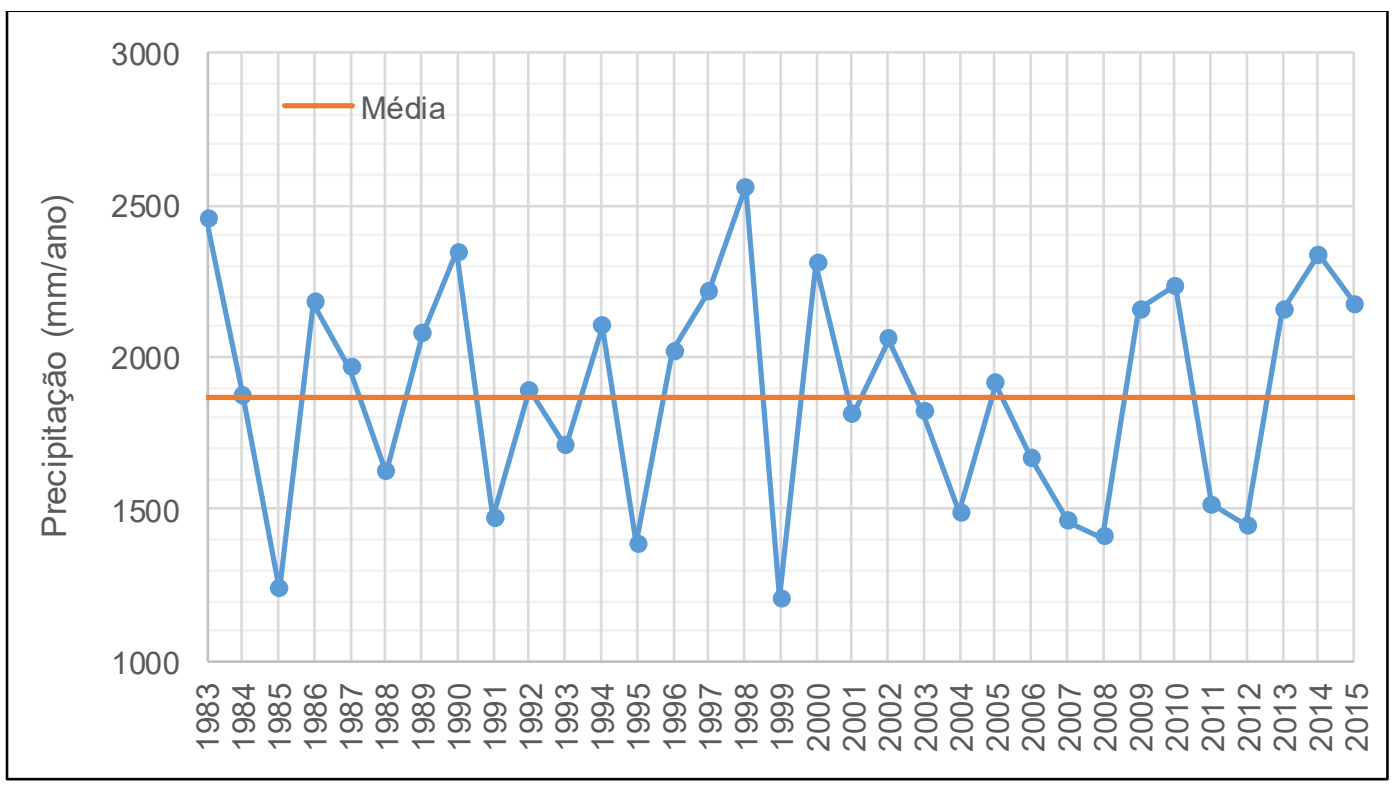

Figura 3.6 - Histórico de precipitações médias anuais (Itaipu Binacional)

\subsection{2}

\section{Vazões}

A Figura 3.7 mostra as vazões afluente no reservatório, turbinada e vertida entre 2010 e 2016. De uma maneira simplificada, para manter o nível do reservatório constante, a vazão afluente deve ser a soma das vazões turbinada e vertida, talvez com alguns dias de defasagem devido à extensão do reservatório. É possível constatar essa informação no gráfico quando ocorrem picos na vazão afluente e simultaneamente ocorrem picos na vazão de vertimento, já que a vazão turbinada permanece dentro de uma faixa de variação constante. 
Entre junho de 2012 e dezembro de 2015 é possível notar que frequentemente a vazão turbinada é maior que a vazão afluente. Isso mostra que há uma diferença entre a entrada e saída de água que provoca o deplecionamento do reservatório. Nesse período o vertimento ocorreu poucas vezes, somente quando houve picos consideráve is na vazão afluente.

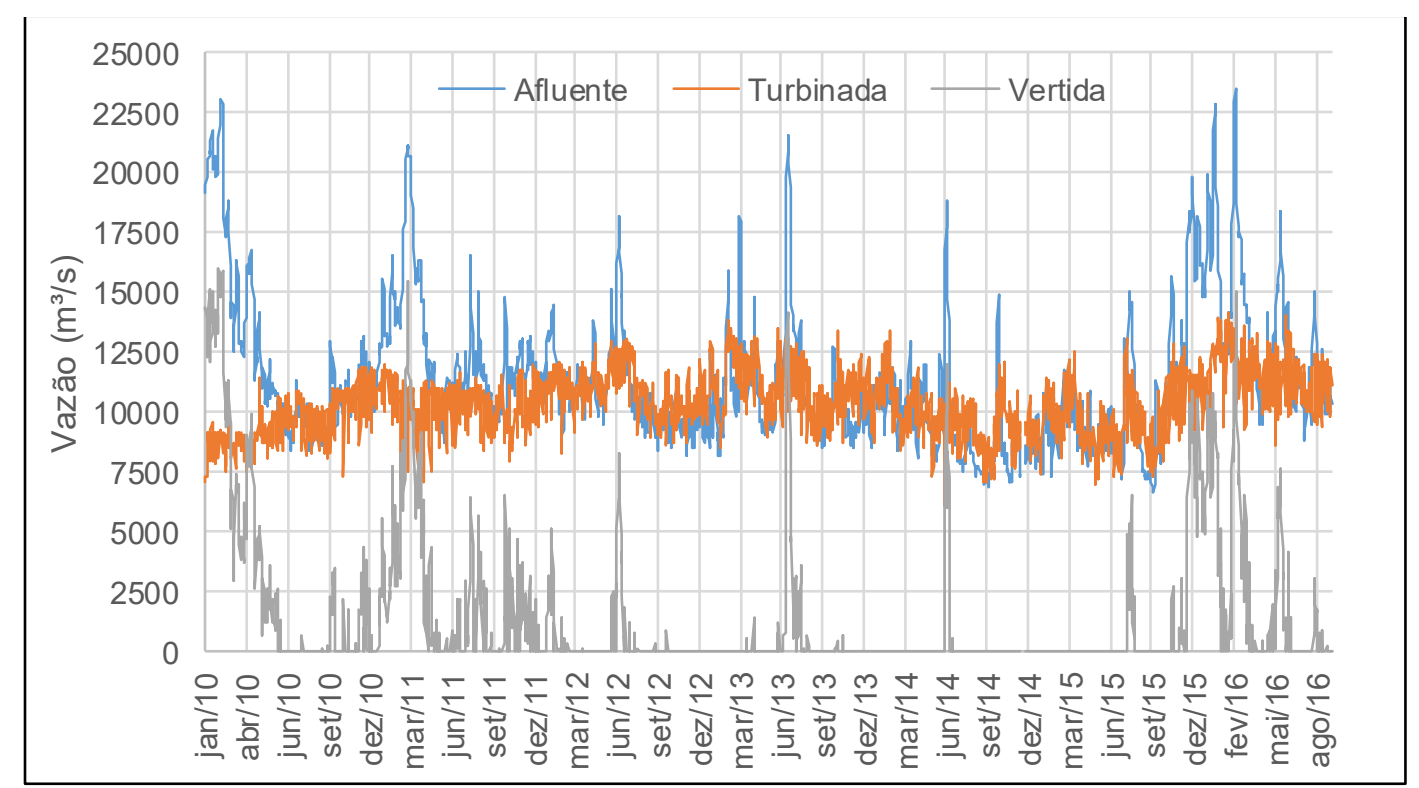

Figura 3.7 - Vazões afluente, turbinada e vertida (Itaipu Binacional)

\subsection{3 \\ Nível do Reservatório}

A barragem de Itaipu foi projetada para operação com nível do reservatório entre as cotas $219 \mathrm{~m}$ e $220,50 \mathrm{~m}$. As medições do nível do reservatório são realizadas diariamente em uma estação nas proximidades da barragem. Analisando o Figura 3.8, que mostra o histórico do nível do reservatório desde o enchimento, é possível verificar que até o ano de 2012 o reservatório sempre esteve dentro dos níveis normais de operação com raros picos para baixo. Tal comportamento é consequência do bom gerenciamento das vazões afluente, turbinada e vertida, que por sua vez são influenciadas por uma série de fatores como: precipitação, vazão afluente de outras bacias, demanda energética, controle de vazão a jusante, entre outros.

Entretanto, em 2012 o reservatório passa a ter um comportamento diferenciado, com rebaixamentos constantes e permanecendo em níveis abaixo do 
normal por maiores períodos de tempo. Tal comportamento pode ser visto com mais detalhes no Figura 3.9.

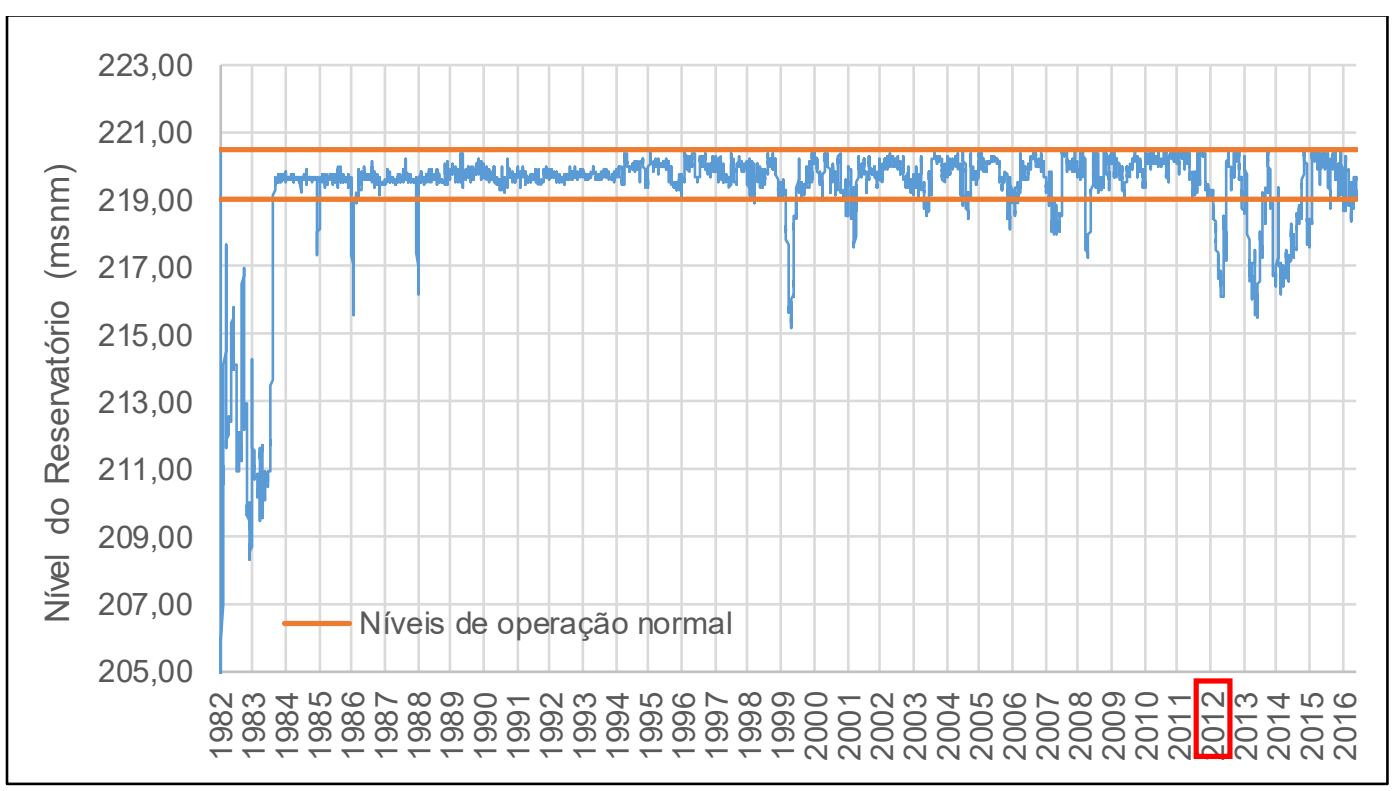

Figura 3.8 - Histórico do nível do reservatório desde o enchimento (Itaipu Binacional)

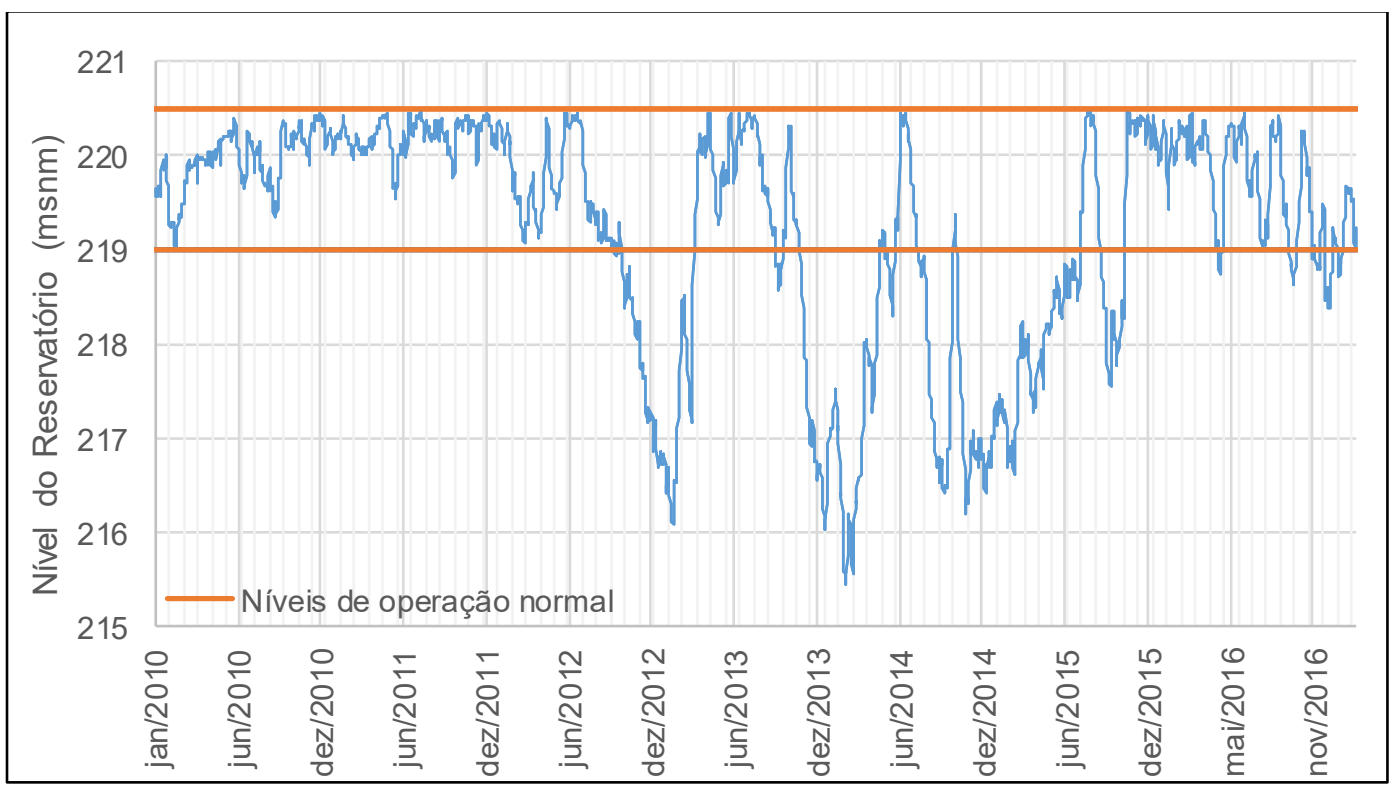

Figura 3.9 - Nível do reservatório de jan/2010 a fev/2017 (Itaipu Binacional)

Nota-se que o reservatório mantém seu nível dentro do padrão ao longo dos anos até que em outubro de 2012 se inicia uma série de rebaixamentos e alteamentos que mantêm o reservatório abaixo do nível normal por um período de aproximadamente três anos, até que em outubro de 2015 o reservatório volta para os níveis normais e assim permanece sem rebaixamentos consideráveis. 
Considerando o período de outubro de 2012 a outubro de 2015 (3 anos), o reservatório esteve abaixo do nível normal durante $70 \%$ desse tempo. Em fevereiro de 2014 atingiu a cota $215,45 \mathrm{~m}$, segunda menor registrada. O histórico mostra que a menor cota registrada foi entre os anos 1999 e 2000 quando o reservatório atingiu a cota $215,15 \mathrm{~m}$ devido um período de seca, mas rapidamente voltou aos níveis normais.

A justificativa do comportamento do reservatório de Itaipu no período de 2012 a 2015 se dá pela crise hídrica ocorrida no país, nesse período as hidrelétricas produziam menos energia devido à escassez de água, enquanto Itaipu, com precipitações acima da média nos anos de 2013, 2014 e 2015, produzia em maior ritmo para a suprir a demanda do Sistema Interligado Nacional (SIN). Tal fato é evidenciado também no Figura 3.7 que mostra as vazões e nota-se que neste período frequentemente a vazão turbinada era maior que a afluente.

\section{4 \\ Instrumentação}

A BTME possui uma série instrumentos que permitem constante avaliação do desempenho da estrutura, são eles: piezômetros (standpipe e elétrico), medidores de nível d'água, medidor de recalque, marcos de referência e medidores de vazão, uma planta contendo locação da instrumentação pode ser vista no Anexo III.

\subsection{1 Piezômetros}

A maioria dos piezômetros são do tipo standpipe (PS) com tubos de PVC de 0,5 polegadas e estão instalados na fundação, apenas um deles (PS-L-19) está instalado no tapete drenante do maciço. Apenas em uma seção $(123+50)$ existem piezômetros a montante do eixo da barragem, no restante todos estão instalados a jusante do eixo da barragem e monitoram as feições entre a argila de fundação e o saprolito, conforme Figura 3.10, ou entre o saprolito e o basalto são, conforme Figura 3.11, região que concentra o maior fluxo da fundação devido ao basalto em alteração, material que possui alta permeabilidade. 


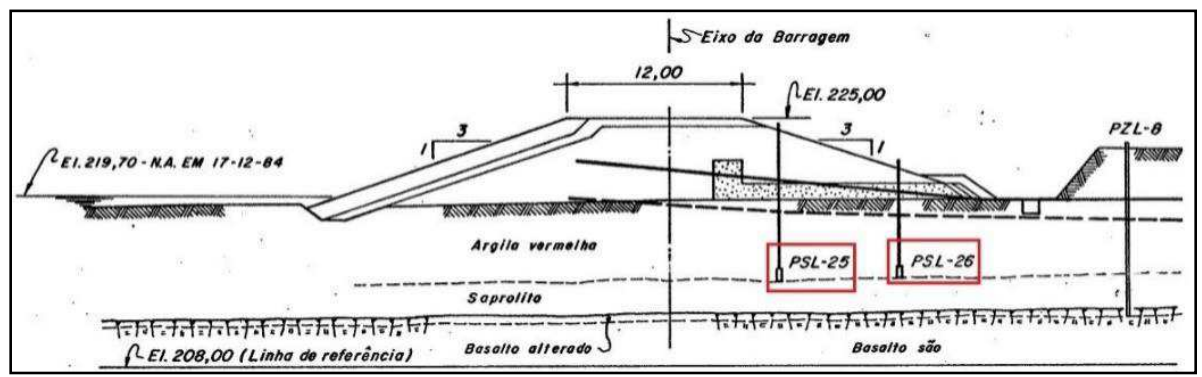

Figura 3.10 - Piezômetros da seção 138+50 (documento interno, SAT. 4286-DI-8125-P)

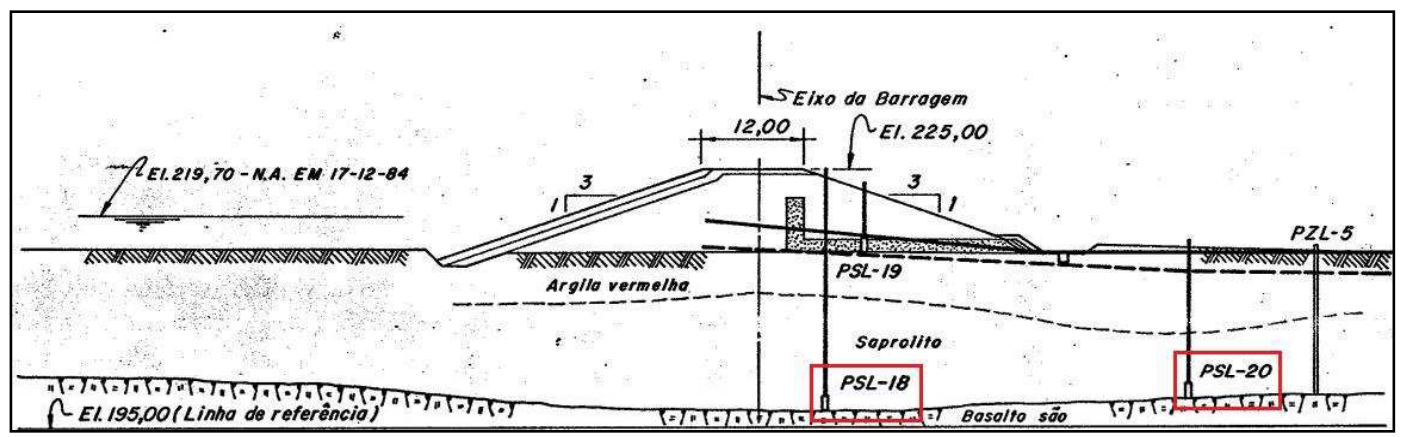

Figura 3.11 - Piezômetros da seção 129+50 (documento interno, SAT. 4286-DI-8124-P)

A variação dos piezômetros instalados no contato do saprolito com a rocha, apresentam correlação direta com a variação do nível do reservatório. O Figura 3.12 mostra os níveis do reservatório e dos piezômetros na altura da estaca 129+50 (Figura 3.11) para o período de 16/10/2012 a 18/09/2015. As leituras do nível do reservatório são realizadas diariamente e dos piezômetros, tipicamente, quinzenalmente.

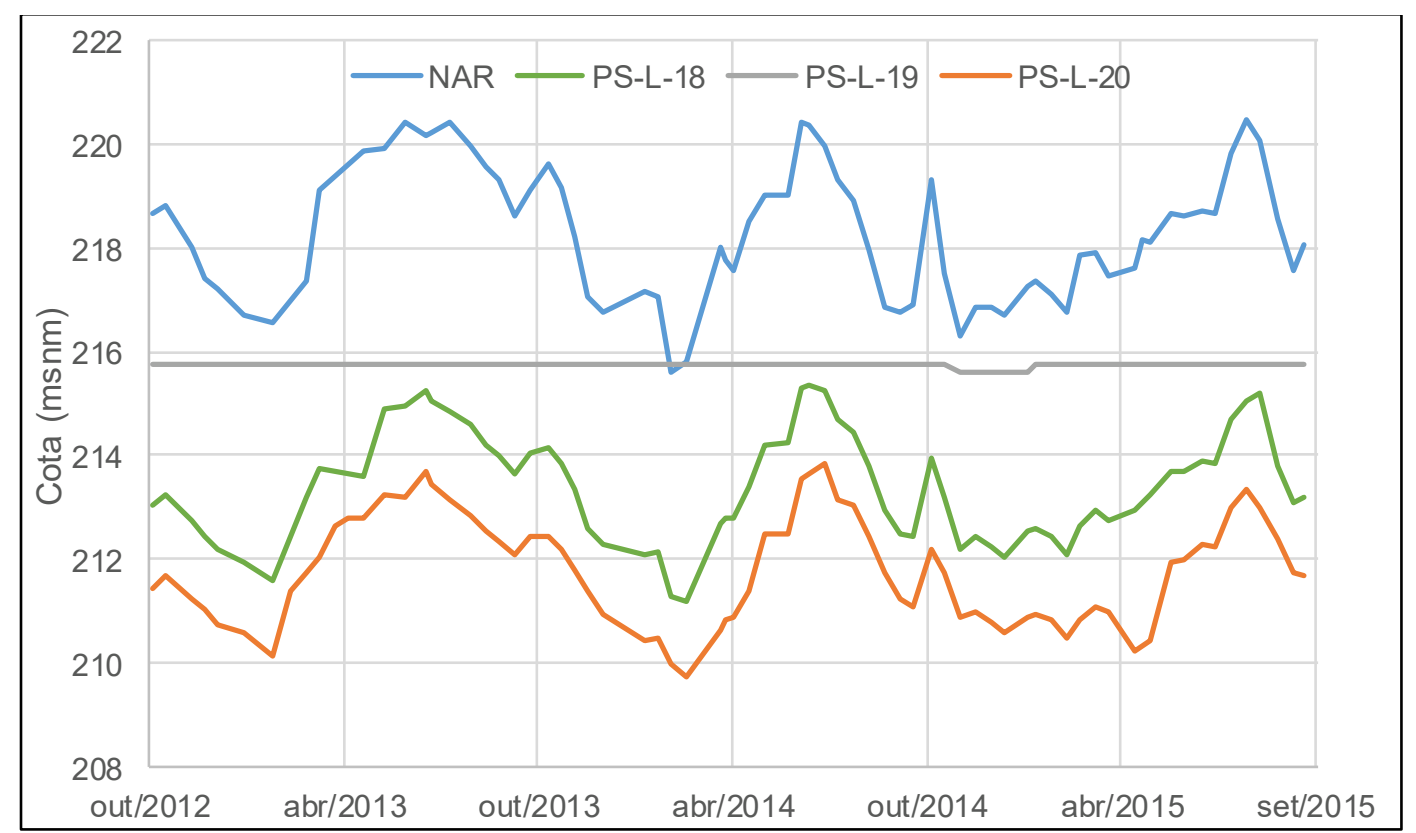

Figura 3.12 - Níveis do reservatório piezômetros na seção da Est. 129+50 (Itaipu Binacional) 
A Figura 3.12 aponta a perda de carga que ocorre entre os piezômetros. O PSL-18 localizado embaixo do maciço compactado e, portanto, mais próximo do reservatório, trabalha com um offset do PS-L-20, que está instalado a jusante do maciço compactado.

O PS-L-19 é o único piezômetro instalado no maciço compactado, como monitora o tapete drenante não há variação em suas leituras, mostrando que não há geração de poropressão no local e a única carga lida é a de elevação.

Para estes, assim como para outros quatro piezômetros instalados no contato entre saprolito e basalto na fundação do trecho sem bermas da BTME, foram realizadas regressões lineares, com cálculo do coeficiente de correlação amostral de Pearson (r) e do coeficiente de determinação $\mathrm{R}^{2}$.

O coeficiente de correlação amostral de Pearson (r) é um parâmetro adimensional que varia de -1 a 1 . A correlação é negativa quando o aumento da variável independente reduz a variável dependente e positiva quando ambas aumentam simultaneamente. Quanto mais próximo de 1 for o resultado, maior é o grau de dependência das variáveis (Figueiredo Filho e Júnior, 2010). O R² é uma medida de ajuste entre valores observados, que varia de 0 a 1 (ou de 0 a 100\%) e mostra o quanto a variação da variável dependente pode ser vinculada à variação da variável independente.

Foram realizadas correlações para o período de outubro de 2012 a outubro de 2015 considerando o nível do reservatório e do piezômetro no mesmo dia e também com defasagens de alguns dias entre eles. Os resultados do piezômetro PS-L-18 são mostrados na Tabela 3.6, os resultados para os demais instrumentos instalados no contato entre saprolito e basalto foram semelhantes.

Tabela 3.6 - Correlação entre o nível do reservatório e o piezômetro PS-L-18

\begin{tabular}{ccc}
\hline Defasagem & $\underline{\mathbf{R}^{\mathbf{2}}(\boldsymbol{\%})}$ & $\underline{\text { Coef. de cor. Pearson }}$ \\
\hline Sem defasagem & $\mathbf{9 0 , 8 4}$ & $\mathbf{0 , 9 5}$ \\
1 dia & 90,71 & 0,95 \\
2 dias & 89,59 & 0,95 \\
3 dias & 87,62 & 0,94 \\
4 dias & 86,17 & 0,93 \\
\hline
\end{tabular}

Existe uma forte correlação entre a variação do nível d'água do reservatório (NAR) e da resposta do piezômetro, ambos parâmetros provam isso. Com relação 
à defasagem de tempo para resposta do piezômetro à alteração do nível do reservatório, tanto o $\mathrm{R}^{2}$ como o coeficiente de correlação de Pearson apontam uma diferença pequena entre os 5 primeiros dias, entretanto ela mostra-se decrescente a partir do primeiro dia. Conclui-se então que a resposta deste instrumento ao nível do reservatório ocorre, se não no mesmo dia, no primeiro ou segundo dia seguinte.

Foi realizado o mesmo procedimento para os piezômetros PS-L-25 e PS-L26 que estão instalados na fundação da seção 138+50 (Figura 3.10), no contato da argila vermelha com o saprolito. A variação das leituras destes instrumentos também apresentou forte correlação com a variação do NAR, porém a melhor correlação não se deu nos primeiros dias. Conforme mostrado na Tabela 3.7, a correlação tende a aumentar com o passar dos primeiros dias e a melhor correlação é obtida para 4 dias de defasagem.

Tabela 3.7 - Correlação entre o nível do reservatório e o piezômetro PS-L-25

\begin{tabular}{ccc}
\hline Defasagem & $\underline{\mathbf{R}^{\mathbf{2}}(\mathbf{\%})}$ & $\underline{\text { Coef. de cor. Pearson }}$ \\
\hline Sem defasagem & 82,39 & 0,91 \\
1 dia & 92,33 & 0,96 \\
2 dias & 92,97 & 0,96 \\
3 dias & 93,10 & 0,96 \\
$\mathbf{4}$ dias & $\mathbf{9 3 , 5 0}$ & $\mathbf{0 , 9 7}$ \\
5 dias & 93,27 & 0,97 \\
6 dias & 92,71 & 0,96 \\
\hline
\end{tabular}

Tal fato ocorre justamente pela posição do instrumento, por mais que esteja em um contato, essa região possui permeabilidade consideravelmente menor que o contato entre saprolito e basalto, isso faz com que as poropressões se alterem com menor velocidade, justificando a resposta à variação do nível do reservatório por volta do quarto dia.

\subsection{2}

\section{Medidores de Nível d’água}

Os medidores de nível d'água, assim como os piezômetros, ficam a jusante do eixo, exceto o PZ-L-1 que está situado a montante na seção 124+00. Em geral eles possuem um afastamento do eixo maior que os piezômetros e sempre estão 
localizados fora do corpo da barragem. Uma seção típica instrumentada com piezômetros e medidor de nível d'água pode ser vista na Figura 3.13.

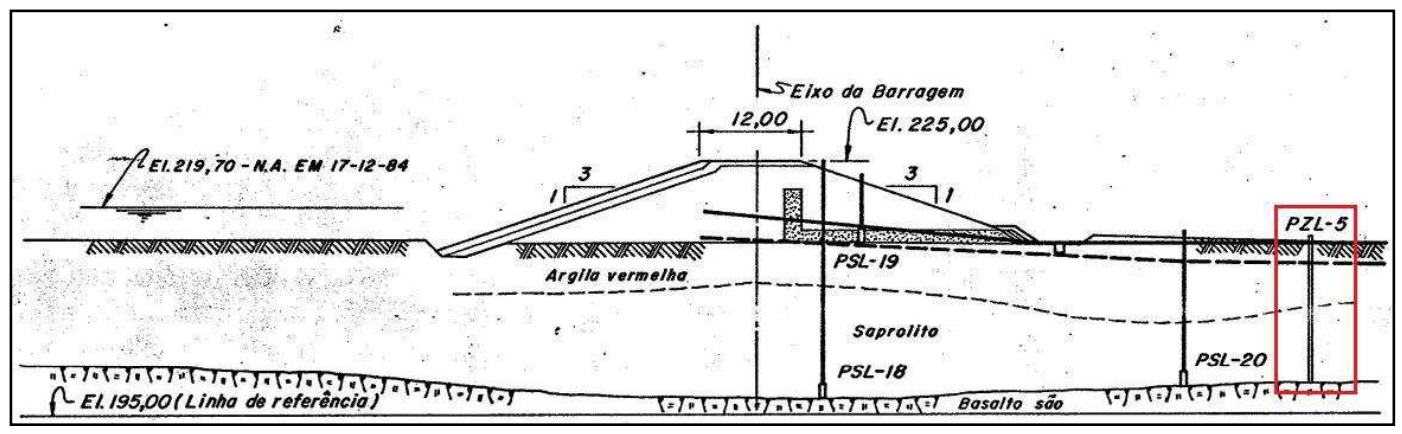

Figura 3.13 - Medidor de nível d'água da seção 129+50 (documento interno, SAT. 4286 DI-8124-P)

Foram realizadas correlações em 4 medidores de níveis d'água instalados no trecho sem bermas, a fim de verificar a relação entre as variações do instrumento e do reservatório. Todas as correlações apresentaram coeficiente de Pearson (r) maior que 0,9 e $\mathrm{R}^{2}$ maior que $80 \%$, apontando forte correlação. Não foi possível avaliar a defasagem de tempo entre a alteração do reservatório e do medidor de nível d'água pois os valores ficaram bastante próximos para correlações com até 6 dias de defasagem. Isso pode ser justificado pelo afastamento do eixo da barragem e pela influência do nível d'água a jusante do instrumento.

\subsection{3 \\ Medidores de Vazão}

Existem no total seis medidores de vazão na BTME, toda água proveniente da drenagem interna da barragem desagua em um sistema de canaletas e é contabilizada em dois medidores de placa triangular, são eles:

- MV-L-2 - mede a vazão provinda das canaletas da estaca 130+50 até o final da barragem na estaca $142+36,50$;

- MV-L-3 - mede a vazão entre o trecho de transição e estaca 130+50;

Outros quatro medidores, dois de placa triangular e dois tubos que são medidos com provetas graduadas, estão instalados na barragem para leituras de vazão a jusante ou de pontos específicos, são eles:

- MV-L-1 - placa triangular que mede a vazão de água coletada de um sistema de espinhas de peixe instalado a jusante da canaleta de drenagem do pé da barragem na altura da estaca $123+90$; 
- MV-L-4 - placa triangular que mede vazão de água proveniente da jusante do pé da barragem, na altura da estaca $123+76$;

- MV-L-5 - tubo instalado no fundo da canaleta de drenagem do pé da barragem, o qual permite leitura da vazão com uma proveta graduada, está instalado na estaca $124+11$;

- MV-L-6 - tubo que coleta água de um sistema de drenagem instalado a montante da saída do filtro, na estaca $124+15$.

Os MV-L-5 e MV-L-6 desaguam na canaleta que passa pela MV-L-3. Próximo ao MV-L-2 existe um bueiro de drenagem que é responsável pela maior parte da vazão deste medidor, tal bueiro conduz água de um sistema de drenagem localizado a jusante da canaleta. As plantas contendo o sistema de drenagem superficial podem ser vistas no Anexo IV.

As vazões infiltradas nas barragens de aterro apresentam forte correlação com o nível do reservatório sem defasagem de tempo (Patias et al. 2015).

\subsection{4 \\ Medidores de Recalque}

Os medidores de recalques foram instalados com objetivo de determinar, com relação à uma referência fixa, o deslocamento vertical de placas instaladas na fundação e interior do maciço compactado. No total foram instalados 9 medidores sendo que 2 deles estão no maciço compactado e possuem mais de uma placa, permitindo detectar deslocamentos na fundação e maciço compactado distintamente, o restante está instalado na fundação fora do maciço compactado. Até 2006 esses instrumentos se mostravam plenamente estabilizados desde a conclusão da construção da barragem, então por recomendação da Junta de Consultores Civis as medições deixaram de serem feitas e o monitoramento de recalques passou a ser feito apenas com levantamento altimétrico.

\subsection{5}

\section{Marcos de Referência}

Os deslocamentos verticais da crista ao longo de toda a barragem são medidos tipicamente duas vezes por ano, uma vez no inverno e outra no verão. $O$ levantamento altimétrico é realizado sobre marcos de referência que são instalados 
no concreto na crista da barragem. A BTME possui marcos de referência longitudinalmente a cada 60 metros, o Anexo V mostra a disposição deles ao longo da crista.

A BTME é o trecho da barragem que acumula o maior recalque desde a construção, tal fato era esperado já que o enchimento do reservatório causou adensamento do maciço e das camadas de fundação. Entretanto, após o enchimento os recalques estabilizaram e apresentaram valores compatíveis, com destaque apenas para o MR-L-23 (estaca 135+79) que entre 1999 e 2000 apresentou recalque de 2,5 cm, mas em seguida estabilizou-se em novo patamar. O comportamento do MR-L-23 foi atribuído a provável assentamento do maciço ou acomodação dos blocos do rip-rap.

Em 2008 o MR-L-20 (estaca 133+99) e MR-L-23 apresentaram uma tendência de recalque com aproximadamente $1,8 \mathrm{~cm}$ de variação. Os valores estabilizaram até quando, em 2012, entre os marcos MR-L-19 e MR-L-24, que corresponde a uma distância de aproximadamente 300 metros entre as estacas $133+39$ e 136+39, houve tendência de recalque, com destaque novamente para o MR-L-20 e MR-L-23 com deslocamentos de aproximadamente $30 \mathrm{~mm}$. Aparentemente, a partir de 2015, os recalques foram estabilizados. É possível verificar tais comportamentos na Figura 3.14.

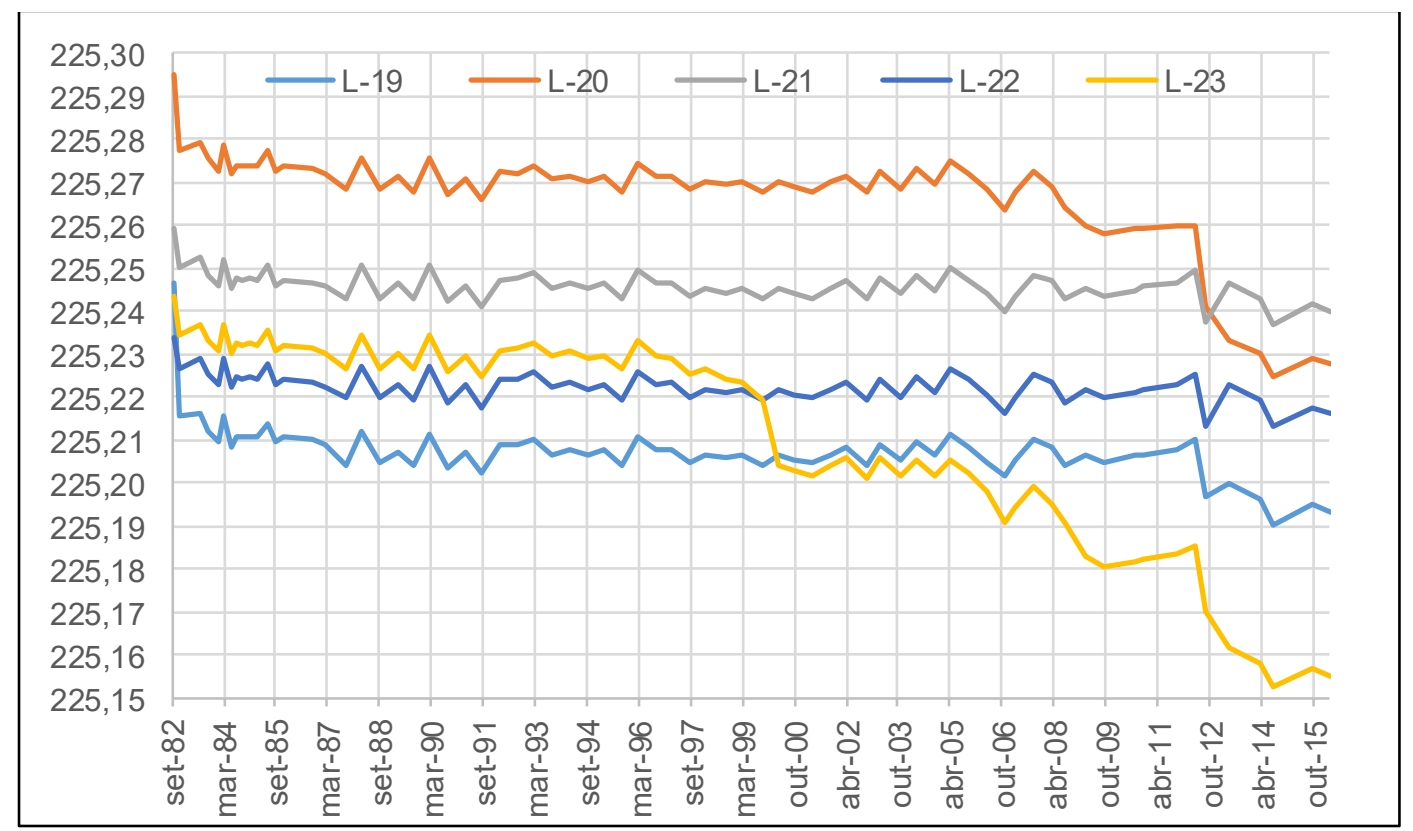

Figura 3.14 - Recalques nos medidores L-19, L-20, L-21, L-22 e L-23 (Itaipu Binacional) 


\section{4 \\ Modelagem Numérica e Resultados}

Para realização das análises propostas foi optado pelo programa GeoSlope, que possui módulos que realizam análise de fluxo (SEEP/W), estabilidade (SLOPE/W) e tensão-deformação (SIGMA/W).

$\mathrm{O}$ SEEP/W analisa o fluxo de água subterrâneo em materiais porosos pelo método dos elementos finitos utilizando a equação diferencial de Laplace. O output é usado pelo SLOPE/W, que realiza análise de estabilidade pelos métodos de equilíbrio limite. O SIGMA/W analisa o comportamento tensão-deformação por meio da teoria da elasticidade, considerando possível adensamento primário do solo.

Conforme o capítulo anterior, os marcos de referência 19, 20, 21, 22, 23 e 24, entre as estacas $133+39$ e $136+39$, foram os que apresentaram tendência de recalque a partir de 2012, ano que o reservatório passou operar em cotas abaixo do normal. A localização desses instrumentos é mostrada na Figura 4.1.

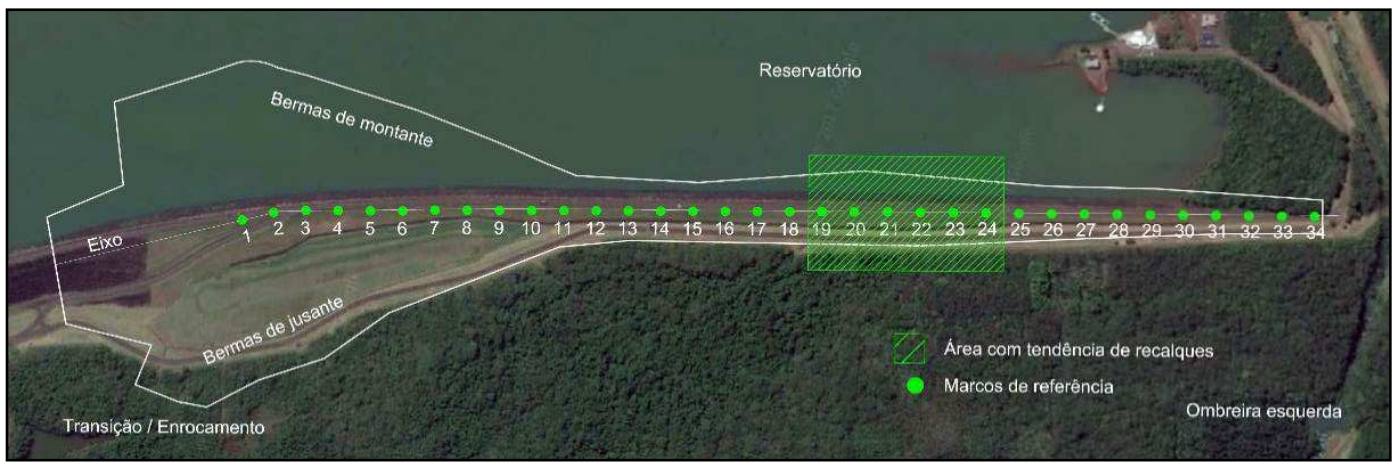

Figura 4.1 - Marcos de referência instalados na BTME (adaptado do Google Maps, acesso em 07/08/2017)

Assim, foram escolhidas quatro seções próximas com instrumentos que possibilitaram determinar as condições de contorno e validar o modelo, são elas: $129+50,132+00,135+50$ e $138+50$. A posição dessas seções é mostrada na Figura 4.2 . 


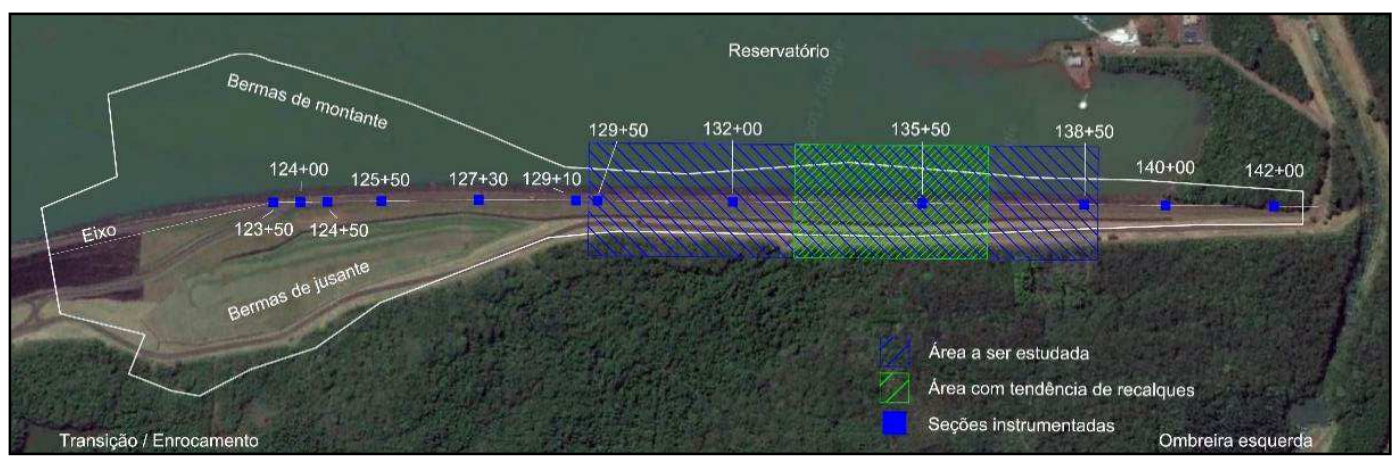

Figura 4.2 - Área estudada da BTME (adaptado do Google Maps, acesso em 07/08/2017)

O estudo feito nessas quatro seções é representativo para o trecho I da BTME pois contempla do início desse trecho, logo na transição com o trecho II, até a região onde o reservatório usualmente atinge o pé do talude de montante. A partir da seção 138+50 o nível do terreno a montante atinge cotas acima da cota de operação de Itaipu e por isso o talude de montante da barragem próximo a ombreira esquerda permanece seco.

Para representar o comportamento do reservatório foi determinado o período de 08/10/2012 a 19/10/2015, essas datas também correspondem ao período que ocorreu a tendência de recalque no trecho citado acima.

Além das análises neste período, foram realizados estudos de caso considerando rebaixamentos rápidos e obstrução do sistema de drenagem.

\section{1 Modelagem das Seções}

As seções foram modeladas previamente em CAD e em seguida exportadas para o programa GeoSlope, a geometria do maciço compactado foi definida de acordo com os desenhos elaborados pelo consórcio projetista (Anexo VI) e disposições de campo que eram elaboradas no decorrer da construção. A fundação foi modelada de acordo com sondagens realizadas no período de investigação e perfis de instalação dos piezômetros e medidores de nível d'água. Os instrumentos foram locados de acordo com os projetos de instrumentação (Anexo VII). As seções modeladas com a devida instrumentação são mostradas nas Figuras 4.3, 4.4, 4.5 e 4.6. A Tabela 4.1 apresenta as principa is características de cada seção. 


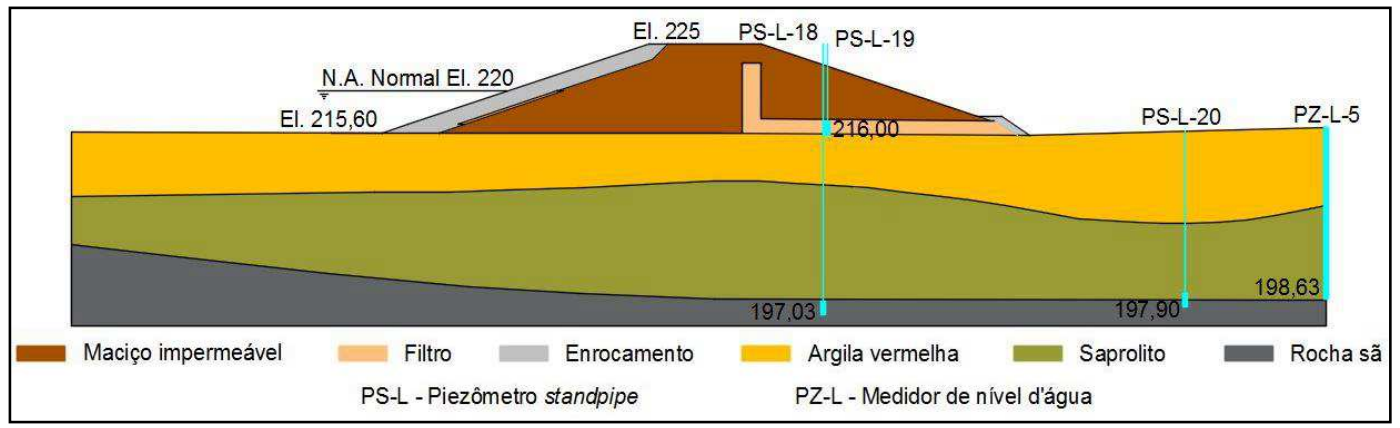

Figura 4.3 - Seção $129+50$ modelada

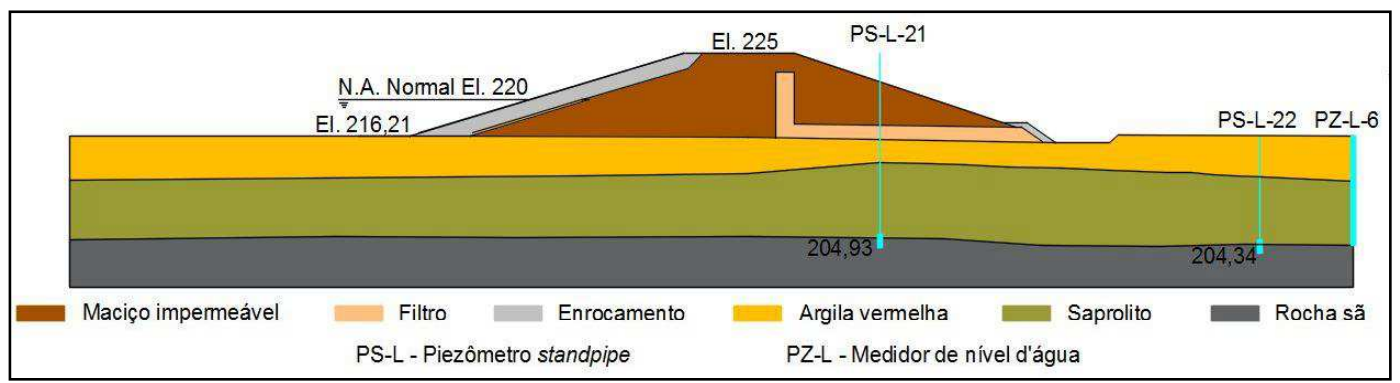

Figura 4.4 - Seção 132 + 00 modelada

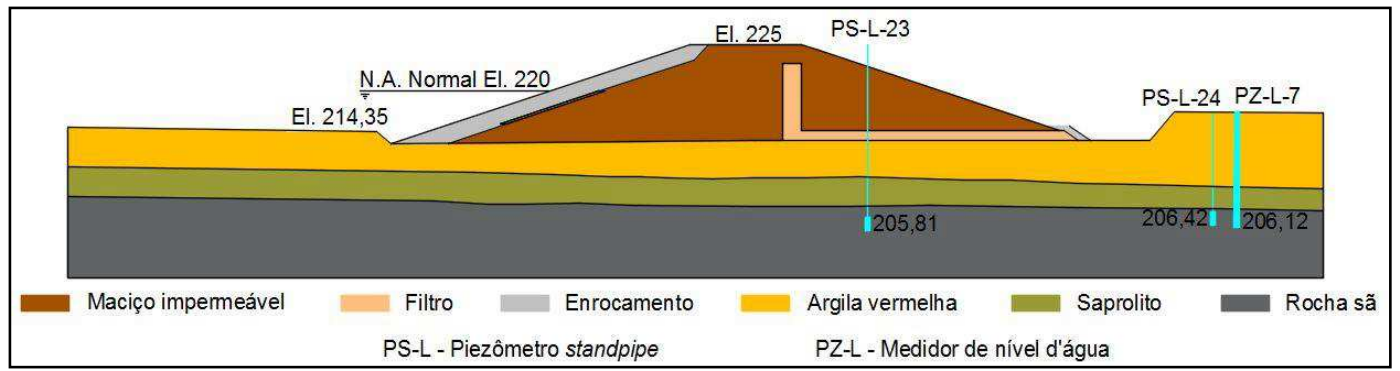

Figura 4.5 - Seção $135+50$ modelada

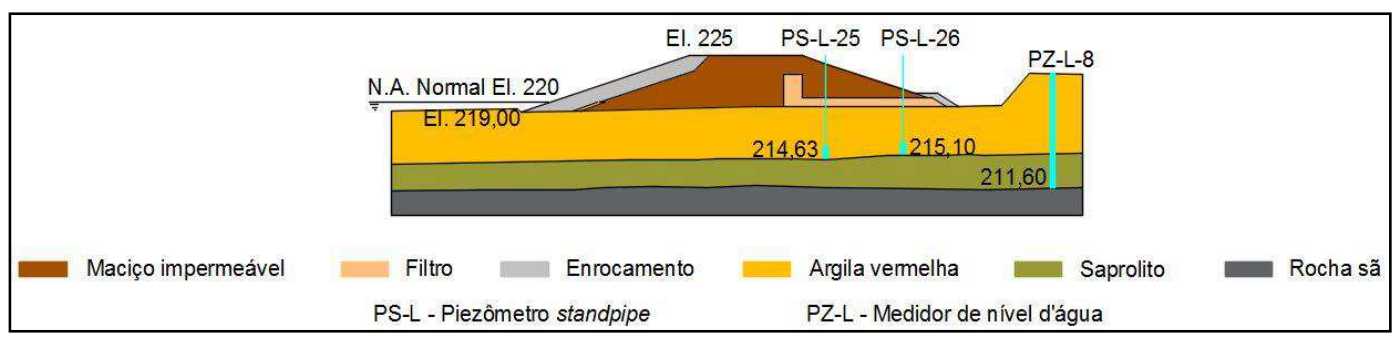

Figura 4.6 - Seção $138+50$ modelada

Tabela 4.1 - Resumo das principais características das seções

\begin{tabular}{ccccc} 
& $\begin{array}{c}\text { Alt. do maciço } \\
\text { compac. (m) }\end{array}$ & $\begin{array}{c}\text { Esp. de argila } \\
\text { fund. (m) }\end{array}$ & $\begin{array}{c}\text { Esp. de saprolito } \\
\text { na fund. (m) }\end{array}$ & $\begin{array}{c}\text { Pé do talude } \\
\text { de mont. (m) }\end{array}$ \\
\cline { 2 - 6 } $129+50$ & 9,5 & 5,0 & 12,5 & 215,60 \\
$132+00$ & 9,0 & 4,0 & 7,0 & 216,21 \\
$135+50$ & 10,5 & 4,0 & 3,0 & 214,35 \\
$138+50$ & 5,5 & 5,5 & 3,0 & 219,00 \\
\hline
\end{tabular}


Após inserção da geometria no programa foi gerada a malha com elementos quadrados de aproximadamente $50 \mathrm{~cm}$ de aresta. Próximo as bordas, ou quando necessário, foi habilitada a opção de elementos triangulares. As respectivas malhas para cada seção serão mostradas adiante.

\section{2}

\section{Análise de Fluxo}

Foram realizadas análises de fluxo considerando regime permanente $\mathrm{e}$ transiente. As análises sob regime permanente foram utilizadas para calibração do modelo e alguns estudos de caso. O regime transiente foi usado para simular o período estabelecido para estudo e os estudos de casos de rebaixamento rápido.

\subsection{1}

\section{Condições de Contorno}

O nível do reservatório foi usado como condição de contorno na superficie de montante do maciço compactado e da fundação, representando uma equipotencial com carga constante, no caso de fluxo permanente, ou variável, no caso de fluxo transiente. A jusante da BTME, as medidas dos medidores de nível d'água serviram como condição de contorno. No local de instalação do instrumento foi colocada uma condição de contorno na vertical representando também uma equipotencial, constante no caso de fluxo permanente e variável no caso de fluxo transiente. As duas condições de contorno induzem um fluxo montante-jusante devido ao gradiente hidráulico que impõem.

Quando simulado o regime transiente do período proposto, foi inserido nível diário do reservatório. O nível d'água a jusante foi indicado de acordo com a periodicidade de suas leituras, normalmente quinzenais. O nível entre as leituras foi estimado com uma função de ajuste de pontos de dados.

A terceira condição de contorno foi aplicada na saída do tapete drenante, tal condição indica a possibilidade de surgência d'água na saída do dreno. Essa mesma condição também é aplicada na superficie de montante da barragem em caso de rebaixamento do reservatório. 


\subsection{2 Permeabilidades}

Com a geometria e condições de contorno definidas foram realizadas divers as análises de fluxo variando a permeabilidade dos materiais de acordo com os valores obtidos nos três tipos de ensaios, a fim de calibrar o modelo de acordo com a instrumentação. Para isso era simulado um fluxo permanente para determinado nível do reservatório e comparavam-se os valores de carga obtidos pela simulação e os lidos nos piezômetros.

Tal calibração foi feita para duas seções: $129+50$, na qual os piezômetro s estão instalados na camada de saprolito e apresentam resposta ao nível do reservatório no mesmo dia, e $138+50$, onde os piezômetros estão instalados na camada de argila e apresentam defasagem de aproximadamente quatro dias para responder às alterações do NAR.

Foram realizados dois tipos de comparações: a primeira com os valores médios do período entre 02/02/2009 e 20/09/2012, período de aproximadamente três anos e meio em que o reservatório se manteve na faixa normal, a segunda considerando dados pontuais de um dia específico. Para comparação dos valores com os piezômetros instalados na argila de fundação, foi considerada a defasagem de tempo da resposta do instrumento à alteração do NAR discutida no Item 3.4.1.

Após algumas análises, foram adotadas as permeabilidades constantes no relatório de final de construção. As permeabilidades horizontal e vertical do maciço compactado foram as obtidas na época de construção por meio de ensaios de permeâmetro de carga variável com amostras extraídas durante a construção do maciço e moldadas em duas posições. A permeabilidade da fundação mostrada no relatório de final de construção também foi a obtida por meio de ensaios de permeâmetro de carga variável, na época de investigação geotécnica. Neste caso foram moldados corpos de prova em duas direções, mas a permeabilidade se mostrou isotrópica.

Para fins de análise de fluxo os materiais de fundação são considerados saturados, já a argila do maciço compactado assim como o dreno, são considerados parcialmente saturados. Para isso é necessário estimar as funções de teor de umidade volumétrica versus sucção mátrica e condutividade hidráulica versus sucção mátrica desses materiais. A função de teor umidade volumétrica pela suç̧ão 
mátrica é estimada a partir do teor saturado e o tipo de material (ex. argila, argila siltosa, silte, areia siltosa, areia ou pedregulho). A condutividade hidráulica para o solo não saturado é estimada por meio do método de Fredlund \& Xing. Para isso é necessário entrar com a função de teor de umidade volumétrica obtida no passo anterior e a permeabilidade $\mathrm{K}_{\mathrm{x}}$ para o solo saturado.

A Tabela 4.2 apresenta as permeabilidades usadas na simulação, a Tabela 4.3 apresenta o resultado da calibração do modelo na seção $129+50$ para os piezômetros instalados no saprolito e a Tabela 4.4 é referente a seção $138+50$ para os piezômetros instalados na camada de argila.

Tabela 4.2 - Permeabilidades adotada no modelo

\begin{tabular}{cc}
\hline Material & $\begin{array}{c}\text { Permeabilidade } \\
(\mathrm{cm} / \mathrm{s})\end{array}$ \\
\hline Argila compactada & $\begin{array}{c}\mathrm{k}_{\mathrm{h}}=3,4 \times 10^{-7} \\
\mathrm{k}_{\mathrm{V}}=1,3 \times 10^{-7} \\
\text { Argila da fundação }\end{array}$ \\
Basalto & $4,4 \times 10^{-5}$ \\
Dreno & $8 \times 10^{-1}$ \\
Enrocamento & 0,1 \\
Saprolito da fundação & $2,5 \times 10^{-11}$ \\
\hline
\end{tabular}

Tabela 4.3 - Resultado da calibração do modelo para piezômetros no saprolito

\begin{tabular}{ccccccc}
\hline $\begin{array}{c}\text { Data da } \\
\text { leitura }\end{array}$ & Medido & SS-L-18 & \multicolumn{3}{c}{ PS-L-20 } \\
\hline $02 / 02 / 09$ & $212,69 \mathrm{~m}$ & $213,15 \mathrm{~m}$ & $0,46 \mathrm{~m}$ & $211,33 \mathrm{~m}$ & $211,33 \mathrm{~m}$ & 0 \\
$02 / 02 / 09$ & & & & & & \\
$\mathrm{a}$ & $214,03 \mathrm{~m}$ & $214,58 \mathrm{~m}$ & $0,55 \mathrm{~m}$ & $212,33 \mathrm{~m}$ & $212,70 \mathrm{~m}$ & $0,37 \mathrm{~m}$ \\
$20 / 09 / 12$ & & & & & & \\
\hline
\end{tabular}

Tabela 4.4 - Resultado da calibração do modelo para piezômetros na argila

\begin{tabular}{ccccccc}
\hline $\begin{array}{c}\text { Data da } \\
\text { leitura }\end{array}$ & Medido & SS-L-25 & \multicolumn{3}{c}{ PS-L-20 } \\
\hline $02 / 02 / 09$ & $216,51 \mathrm{~m}$ & $217,10 \mathrm{~m}$ & $0,59 \mathrm{~m}$ & $216,40 \mathrm{~m}$ & $216,83 \mathrm{~m}$ & $0,43 \mathrm{~m}$ \\
$02 / 02 / 09$ & & & & & & \\
$\mathrm{a}$ & $218,42 \mathrm{~m}$ & $218,98 \mathrm{~m}$ & $0,56 \mathrm{~m}$ & $218,25 \mathrm{~m}$ & $218,71 \mathrm{~m}$ & $0,46 \mathrm{~m}$ \\
$20 / 09 / 12$ & & & & & & \\
\hline
\end{tabular}


Os valores de permeabilidades foram consideráveis aceitáveis em função da pequena diferença entre as cargas medidas e simuladas e, optou-se por mantê-los para as análises de fluxo transiente.

\subsection{3}

\section{Análise do Período Proposto}

Como definido no Item 4.1, foi determinado o período de 08/10/2012 a 19/10/2015 para representar o comportamento do reservatório. Para esta análise foi simulado fluxo transiente em 1106 etapas, que corresponde ao número de dias ao longo do período considerando a variação diária do NAR.

\section{Seção $129+50$}

A seção $129+50$ possui aproximadamente $9,5 \mathrm{~m}$ de altura e é monitorada por três piezômetros, sendo que dois deles monitoram o contato do saprolito com o maciço rochoso e um deles está instalado no tapete drenante. O PS-L-18 está instalado embaixo do maciço compactado com um afastamento de $11,59 \mathrm{~m}$ do eixo da barragem, já o PS-L-20 fica a jusante do maciço compactado com afastamento de $50 \mathrm{~m}$ do eixo. O PS-L-19 é o único instrumento do trecho estudado que está instalado no maciço compactado e monitora a poropressão no tapete drenante. Para o período em questão, todas as leituras indicaram que o instrumento permanece seco. Uma foto da seção é mostrada na Figura 4.7.

A Figura 4.8 mostra a seção $129+50$ com a malha gerada pelo programa. Em seguida a Figura 4.9 apresenta os valores lidos e simulados para o PS-L-18. A Figura 4.10 mostra a correlação entre os valores lidos e simulados e a Tabela 4.5 apresenta detalhes dessa correlação. 


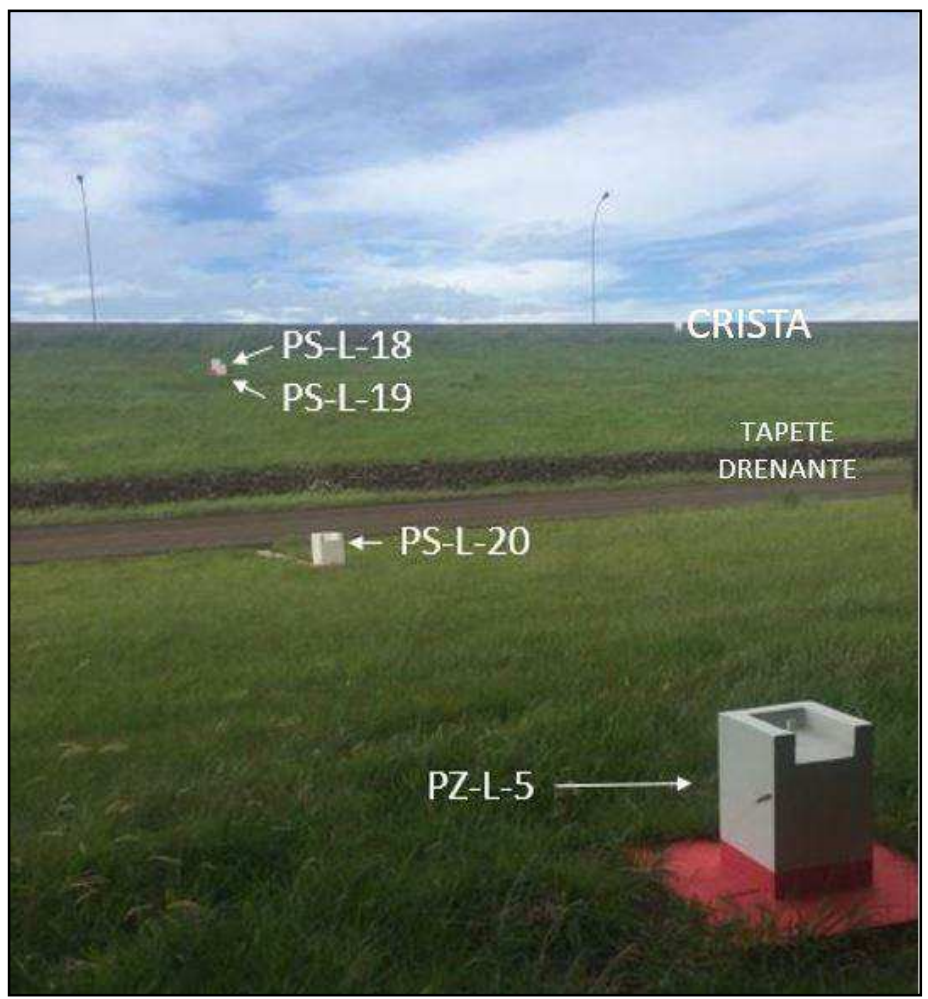

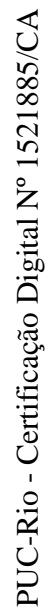

Figura 4.7 - Seção 129+50 da BTME

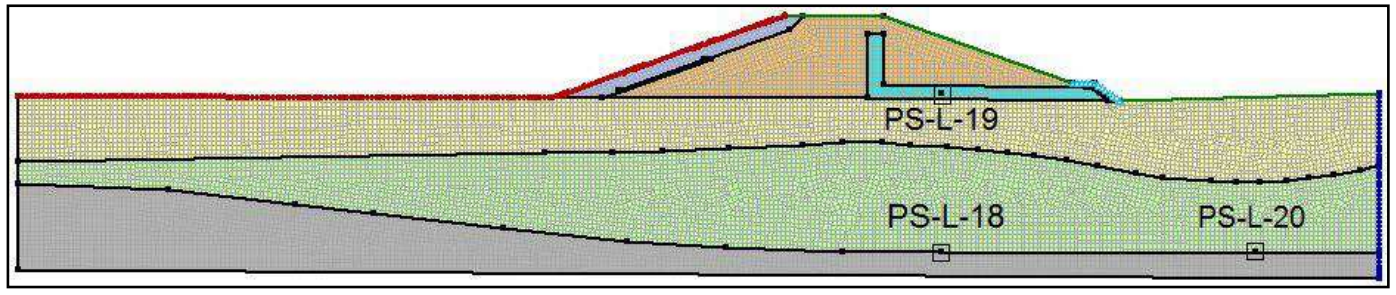

Figura 4.8 - Malha da seção 129+50

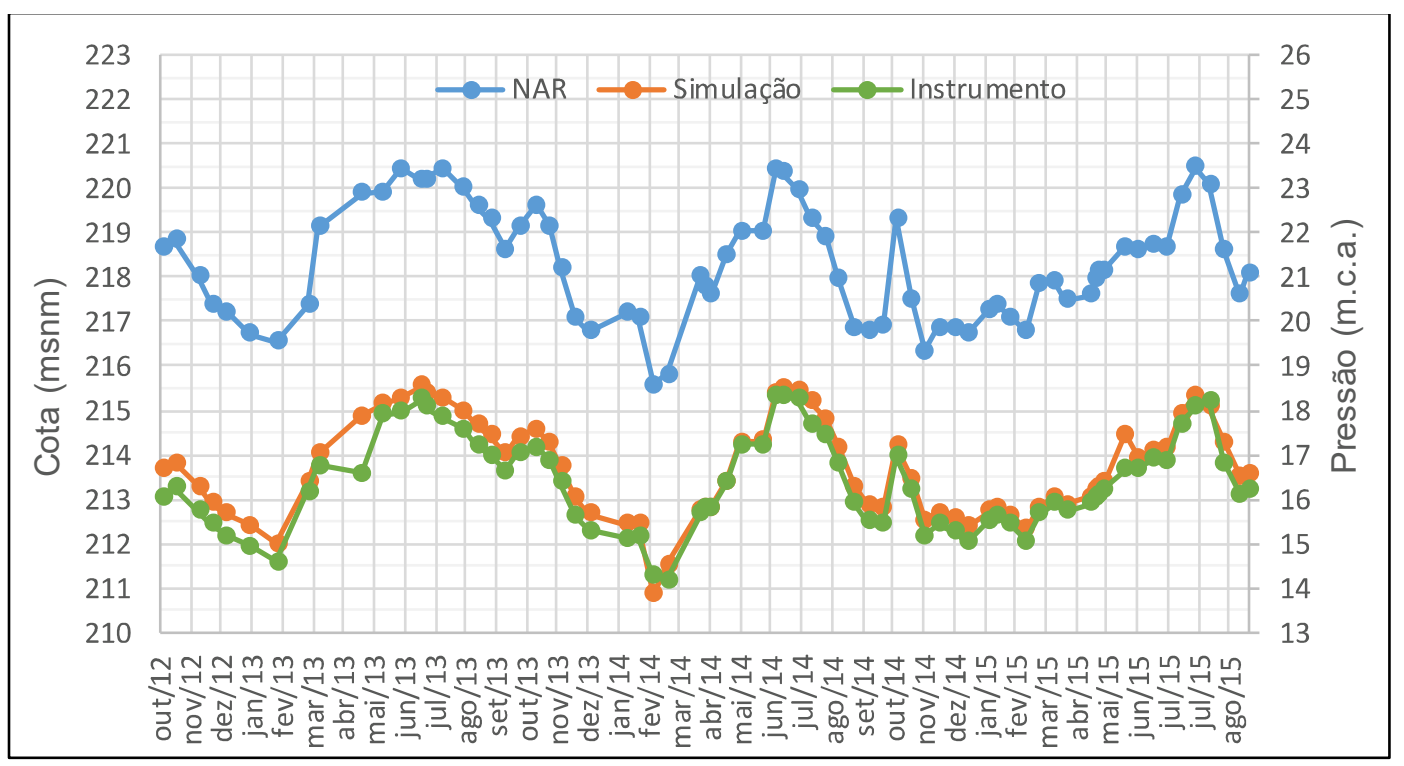

Figura 4.9 - Valores de leitura do PS-L-18 e NAR 


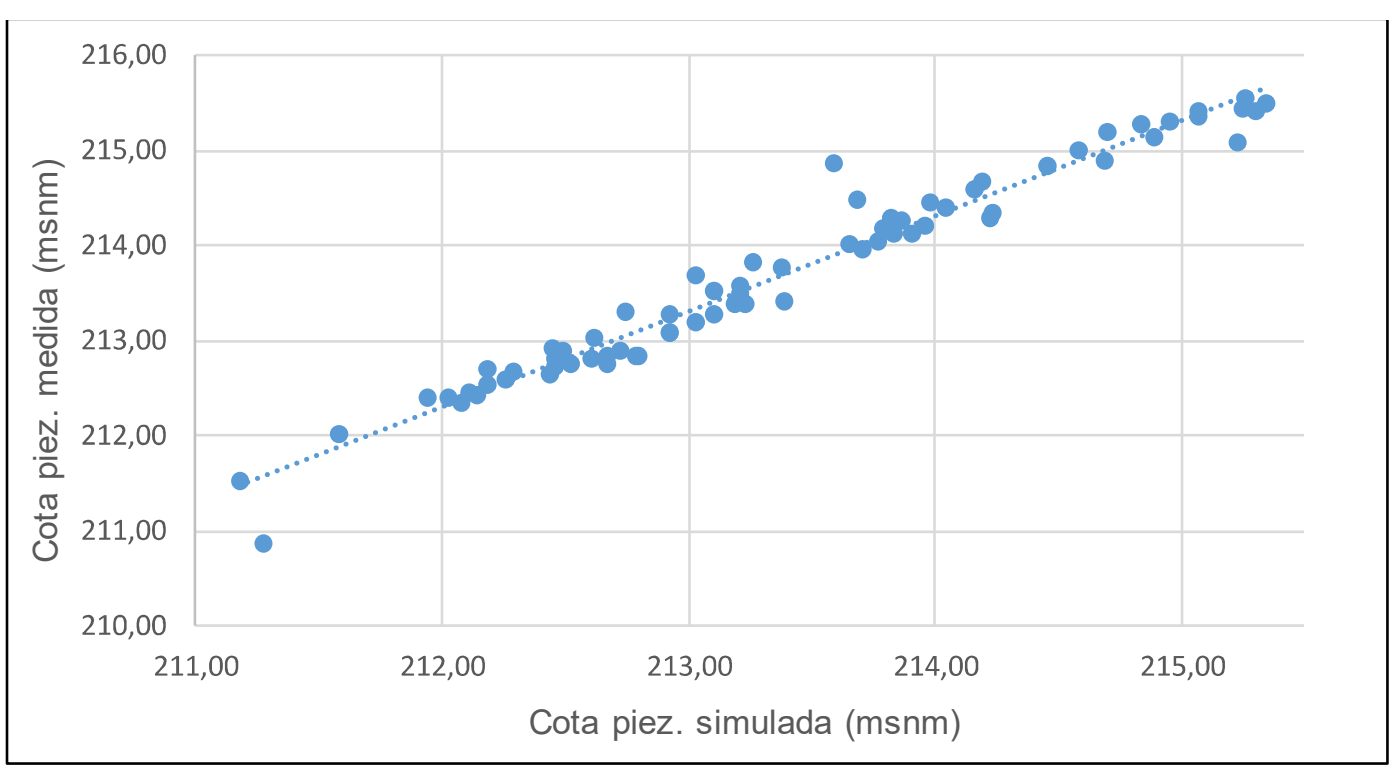

Figura 4.10 - Correlação dos valores lidos e simulados do PS-L-18

Tabela 4.5 - Resultados da correlação entre valores lidos e simulados do PS-L-18

Erro médio $0,32 \mathrm{~m}$

Coef. Correlação de Pearson (r)

Como já visto no Item 3.4, os piezômetros apresentam forte correlação positiva com o nível do reservatório, ou seja, a variação do valor do PS é sempre uma resposta ao comportamento do reservatório.

Nota-se em ambos gráficos que poucos valores apresentaram discrepância entre a leitura e simulação. Quando tal fato ocorre é possível verificar que o valor simulado está respondendo diretamente ao comportamento do reservatório enquanto o valor lido no instrumento apresenta comportamento aleatório, vezes acima e vezes abaixo do valor obtido pela simulação.

A simulação foi considerada bastante representativa com forte correlação e com o erro de $32 \mathrm{~cm}$ considerado aceitável. Tal erro pode estar relacionado, por exemplo, à diferença do local de instalação do instrumento em campo e no modelo e a diferentes valores de permeabilidade, já que o valor adotado no modelo é representativo para determinado material, mas em campo pode ocorrer variação na mesma camada.

O PS-L-20, localizado mais a jusante na mesma seção, possui menor variação e indica valores de carga menores que o PS-L-18, apontando que ocorre perda de carga entre eles. A Figura 4.11 apresenta os valores lidos e simulados para o PS-L- 
20, enquanto a Figura 4.12 mostra a correlação entre eles e a Tabela 4.6 mostra o resultado da correlação.

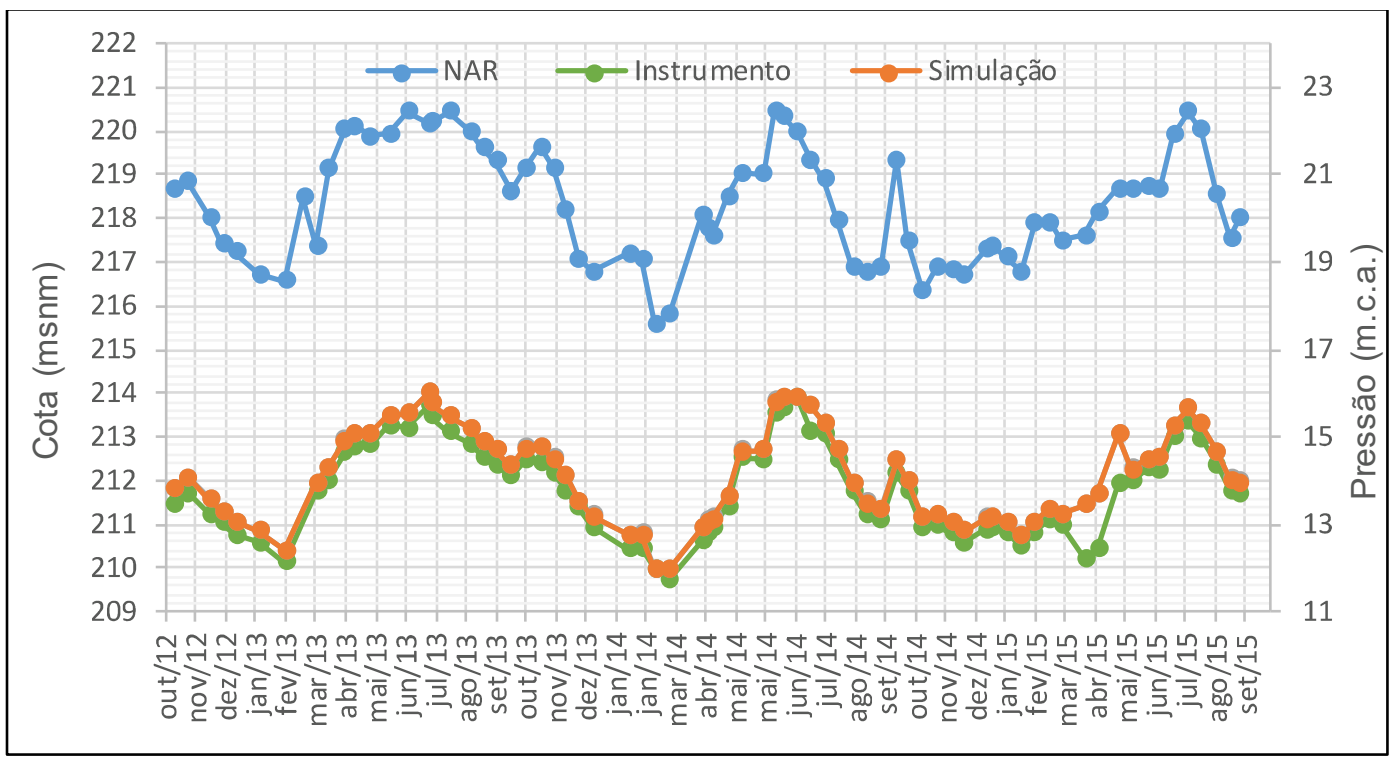

Figura 4.11 - Valores de leitura do PS-L-20 e NAR

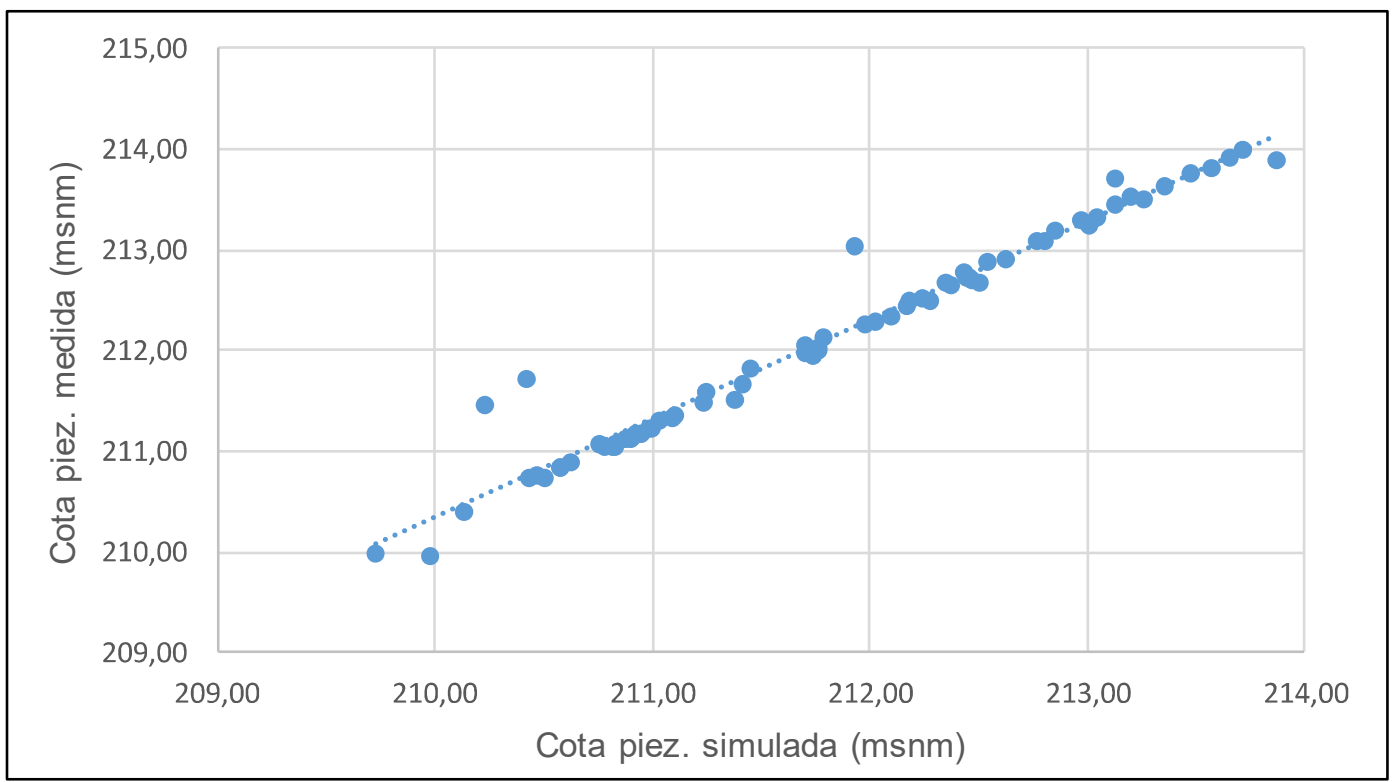

Figura 4.12 - Correlação dos valores lidos e simulados do PS-L-20

Tabela 4.6 - Resultados da correlação entre valores lidos e simulados do PS-L-20 Erro médio $0,31 \mathrm{~m}$

Coef. Correlação de Pearson (r)

$$
0,98
$$

$\mathrm{R}^{2}$ $96,27 \%$

Semelhantemente aos resultados do PS-L-18 os valores lidos e simulados apresentaram forte correlação com poucos valores discrepantes. O erro de $31 \mathrm{~cm}$ foi considerável aceitável. 
A espessura das camadas de fundação varia ao longo do eixo da BTME, a seção $129+50$ é a que possui maior camada de solo na fundação, com aproximadamente $5 \mathrm{~m}$ de argila vermelha e $12,5 \mathrm{~m}$ de saprolito. Como previsto em projeto, a maior parte do fluxo, através da barragem, ocorre pela fundação, na camada de saprolito mais especificamente, isso devido à sua maior permeabilidade quando comparada à dos demais materiais.

A Figura 4.13 mostra os vetores de velocidade através do corpo da barragem e da fundação numa condição de fluxo permanente. É possível verificar que a maior parte do fluxo infiltra pela fundação a montante, passa pela camada de argila com fluxo vertical e chega na camada de saprolito, onde muda de sentido e segue para jusante. Uma pequena parte da vazão que ocorre na fundação chega até o tapete drenante, esse fluxo tende a escoar até chegar à saída do tapete drenante, porém, devido à baixa vazão, parte desse fluxo infiltra novamente na camada de argila.

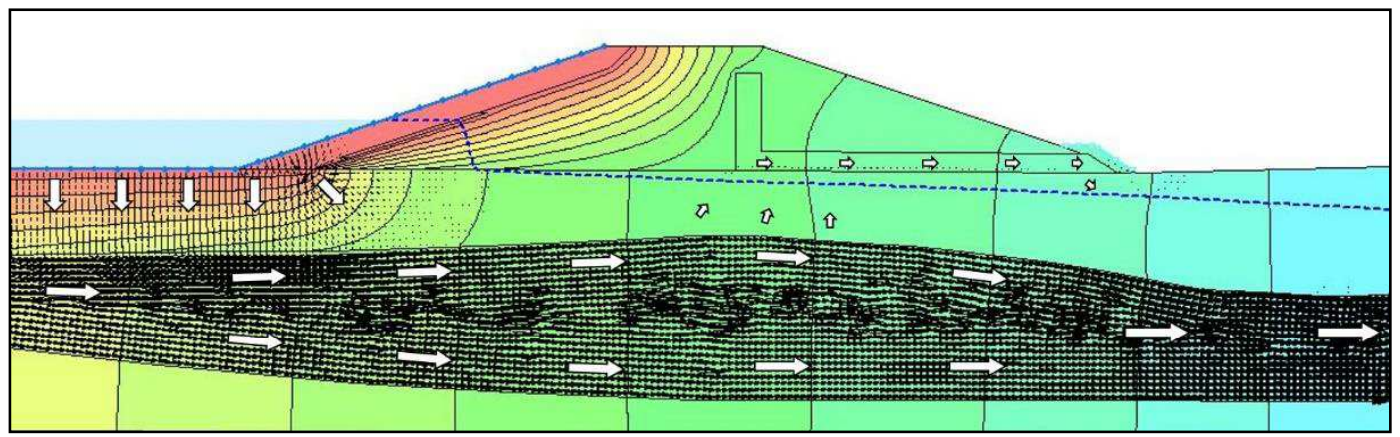

Figura 4.13 - Fluxo através da seção 129+50

Foram obtidas informações diárias sobre a posição da linha freática que varia de acordo com a velocidade da dissipação de poropressões e da variação do nível do reservatório, que impõe o fluxo.

A Figura 4.14 mostra que, para a condição de fluxo permanente, a linha freática adentra no rip-rap e quando entra em contato com o maciço compactado forma uma linha praticamente vertical que vai até a fundação. Quando ocorre o rebaixamento rápido do NAR (Figura 4.15), a linha freática no maciço compactado forma uma curvatura, pois a dissipação de poropressões na fundação é mais rápida devido a maior permeabilidade da argila de fundação quando comparada à argila compactada. No alteamento rápido (Figura 4.16) a linha freática forma uma curvatura na posição invertida do caso anterior, já que a saturação do maciço compactado também ocorre de maneira lenta e iniciada pela superfície do talude em direção ao centro do maciço compactado. 


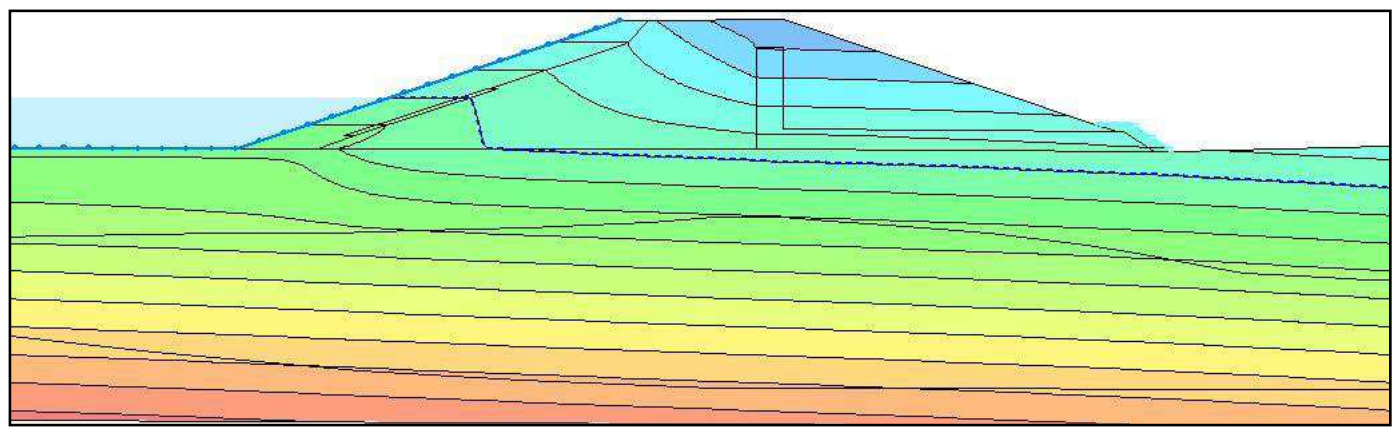

Figura 4.14 - Linha freática para fluxo permanente na seção 129+50

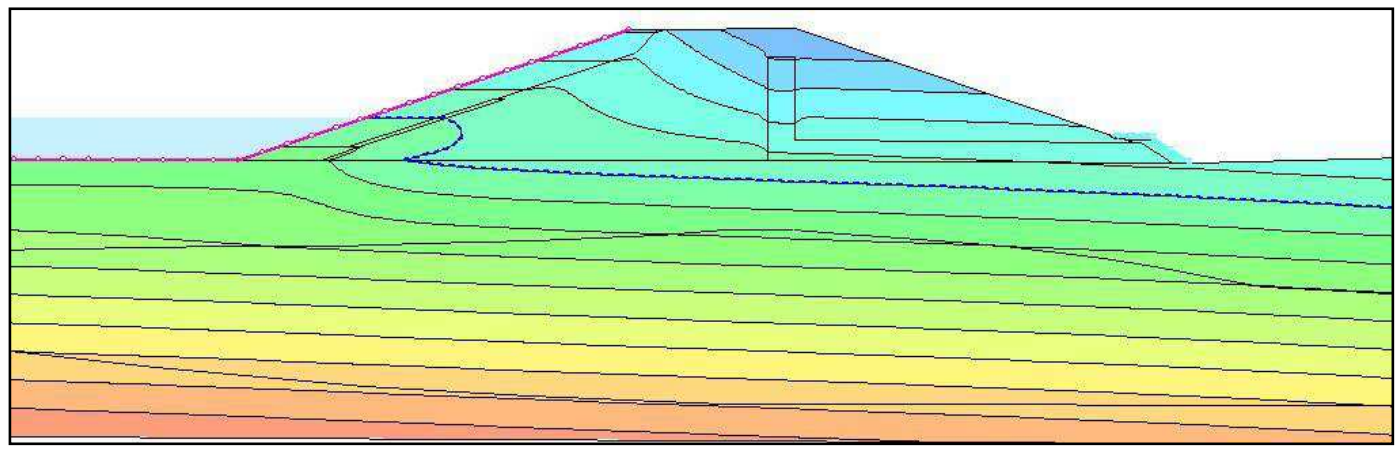

Figura 4.15 - Linha freática para rebaixamento rápido do NAR na seção 129+50

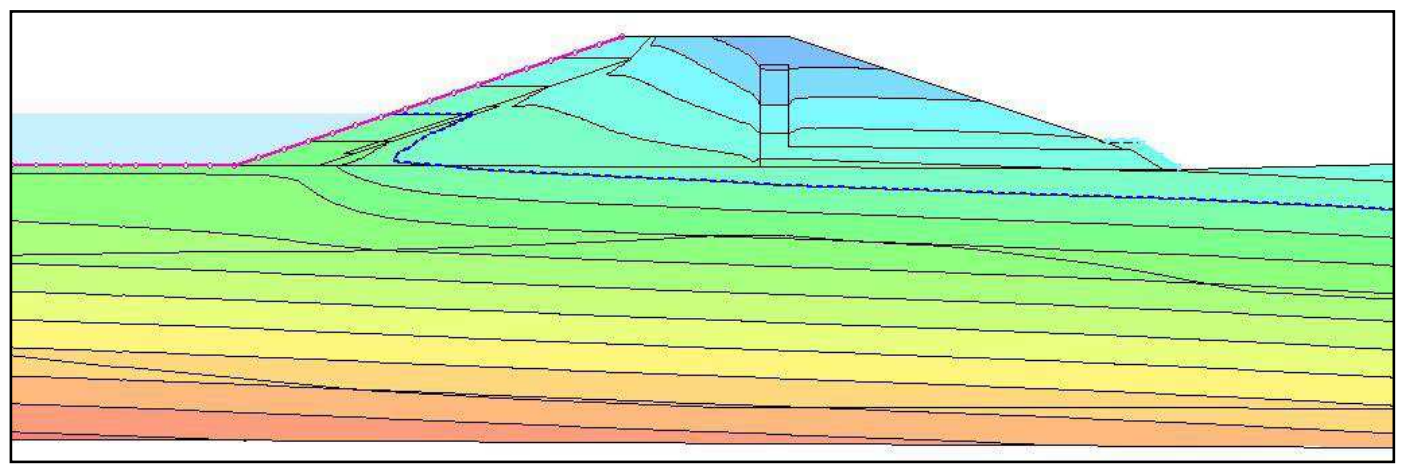

Figura 4.16 - Linha freática para alteamento rápido do NAR na seção 129+50

\section{Seção $132+00$}

A seção $132+00$ possui aproximadamente $9 \mathrm{~m}$ de altura e uma camada de 11 $\mathrm{m}$ de solo na fundação, sendo $4 \mathrm{~m}$ de argila vermelha e $7 \mathrm{~m}$ de saprolito. As poropressões na fundação são monitoradas pelos piezômetros PS-L-21 e PS-L-22. A Figura 4.17 mostra uma foto da seção e a Figura 4.18 a seção modelada com os respectivos instrumentos. A Figura 4.19 apresenta os valores lidos e simulados para o PS-L-21, a Figura 4.20 mostra a correlação entre os valores lidos e simulados e a Tabela 4.7 apresenta detalhes dessa correlação. 


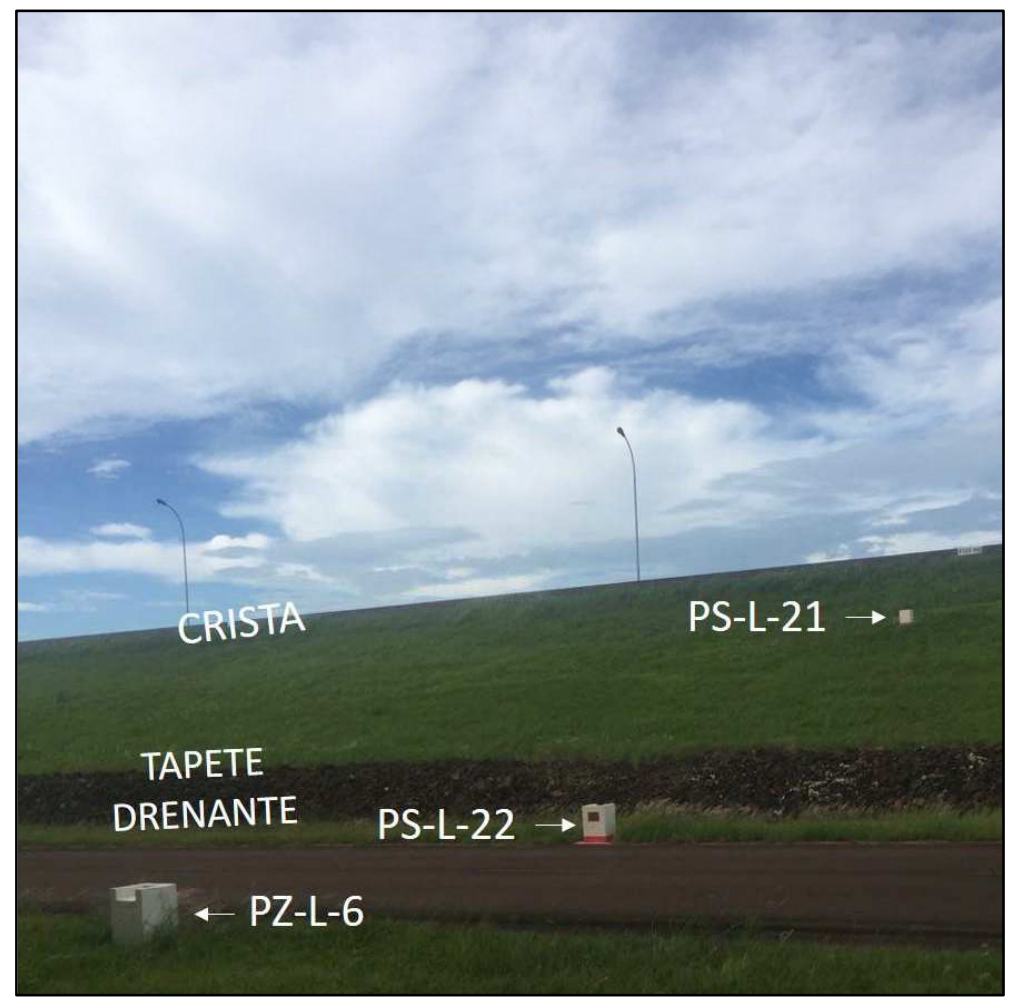

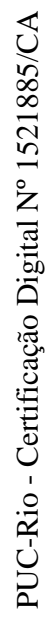

Figura 4.17 - Seção 132+00 da BTME

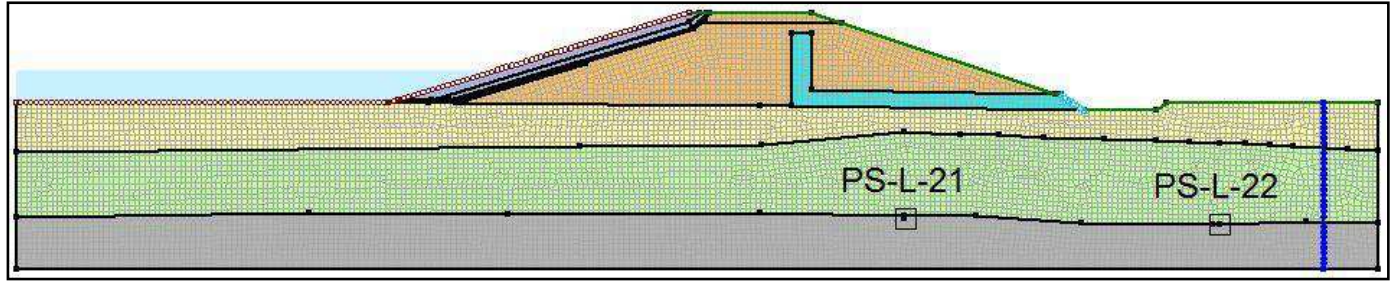

Figura 4.18 - Malha da seção 132+00

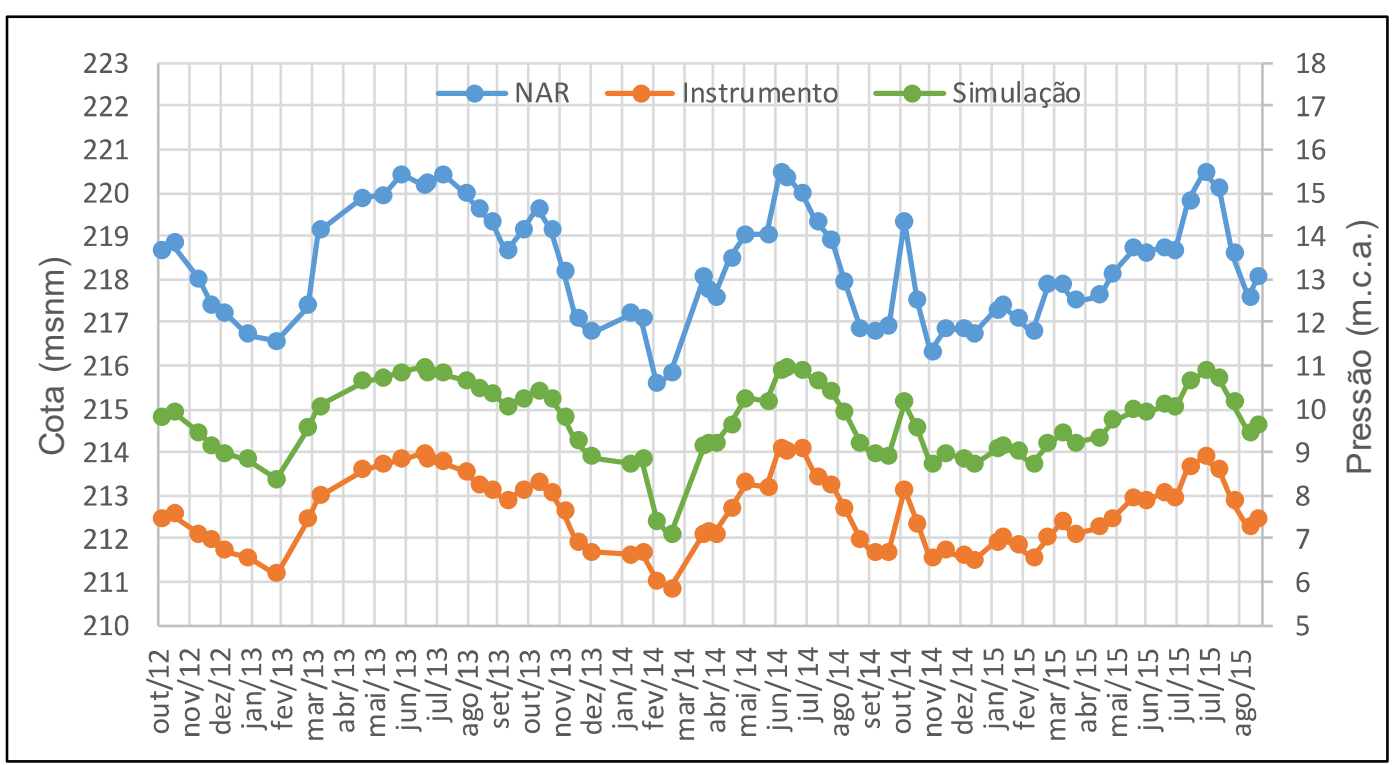

Figura 4.19 - Valores de leitura do PS-L-21 e NAR 


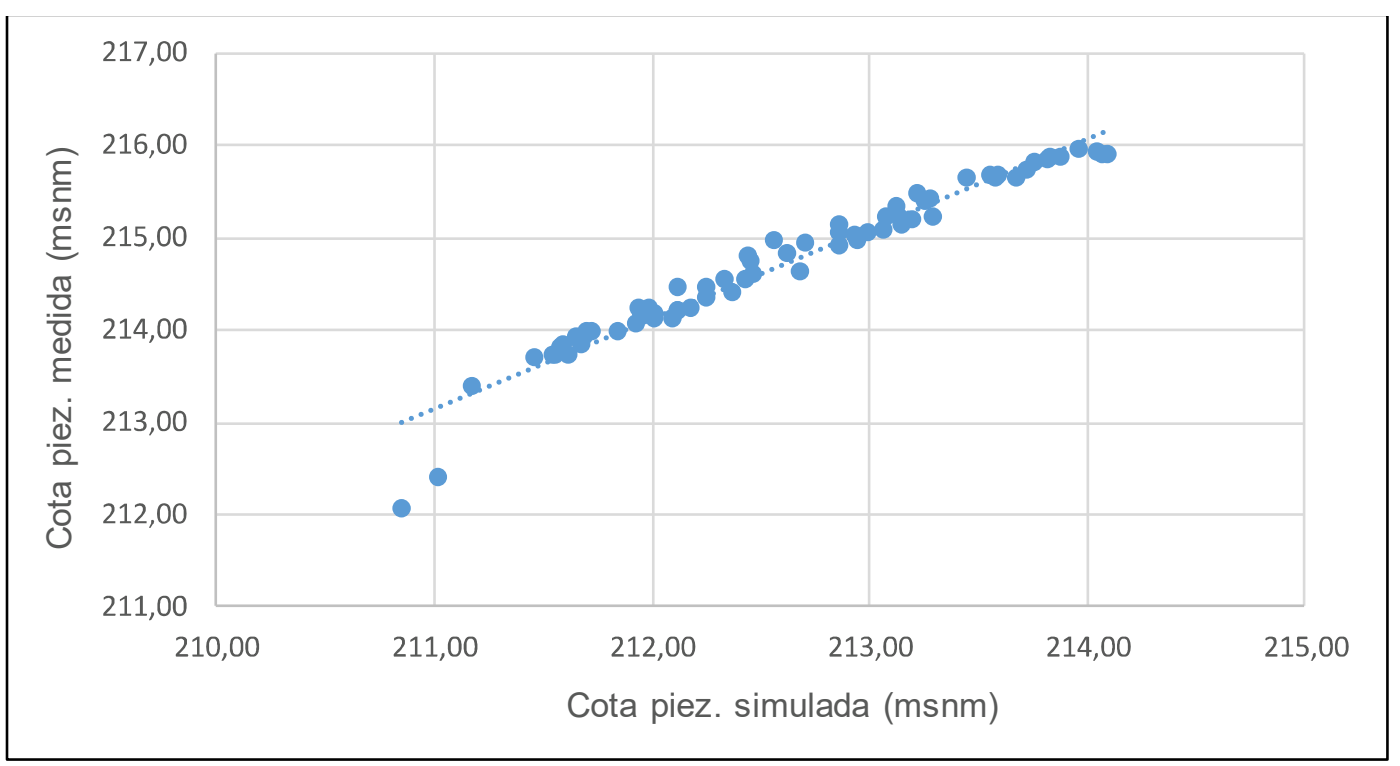

Figura 4.20 - Correlação dos valores lidos e simulados do PS-L-21

Tabela 4.7 - Resultados da correlação entre valores lidos e simulados do PS-L-21 Erro médio $2,10 \mathrm{~m}$

Coef. Correlação de Pearson (r)

Assim como os demais piezômetros instalados no saprolito, os valores de carga obtidos pela simulação para o PS-L-21 apresentaram forte correlação com os valores medidos em campo e com o NAR, no entanto observou-se um offset de aproximadamente $2 \mathrm{~m}$ entre eles, isso é evidenciado pelo erro médio que foi de 2,10 $\mathrm{m}$.

Analisando as leituras realizadas nos dois piezômetros desta seção no mesmo gráfico, nota-se que o PS-L-21, instalado embaixo do maciço compactado, apresenta valores de carga menores que o PS-L-22, instalado a jusante. Tal comportamento pode ser visto na Figura 4.21.

Diferente do comportamento do restante da barragem, nessa seção não ocorre a perda de carga típica no fluxo sentido montante-jusante pela fundação. Tal fenômeno é atribuído ao elevado nível freático no terreno a jusante da barragem neste trecho. O medidor de nível d'água utilizado como condição de contorno localiza-se a $23 \mathrm{~m}$ do pé da barragem, porém mais afastado da barragem o nível d'água tende a aumentar. Neste local, inclusive, existe um sistema de drenagem que coleta água do terreno a jusante. 


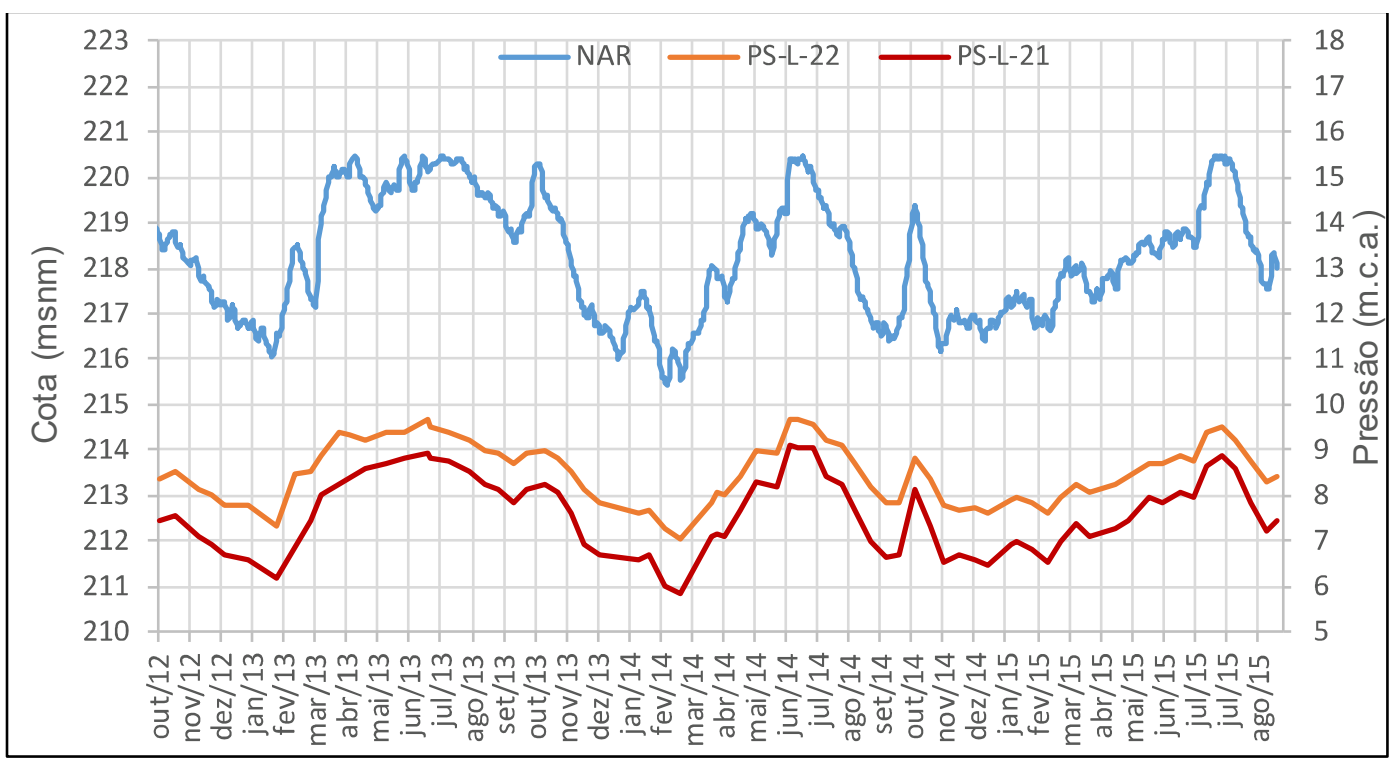

Figura 4.21 - Valores medidos do PS-L-21 e PS-L-22

A solução encontrada para modelar essa seção foi utilizar os valores do PSL-21 como condição de contorno, outra solução seria acoplar um trecho do terreno a jusante no modelo, porém não há informações topográficas e geotécnicas suficientes para tal.

Utilizando o PS-L-21 como condição de contorno os valores obtidos pela simulação para o PS-L-22 ficaram próximos dos medidos em campo. A Figura 4.22 apresenta os valores lidos e simulados para o PS-L-22, a Figura 4.23 mostra a correlação entre os valores lidos e simulados e a Tabela 4.8 apresenta detalhes dessa correlação.

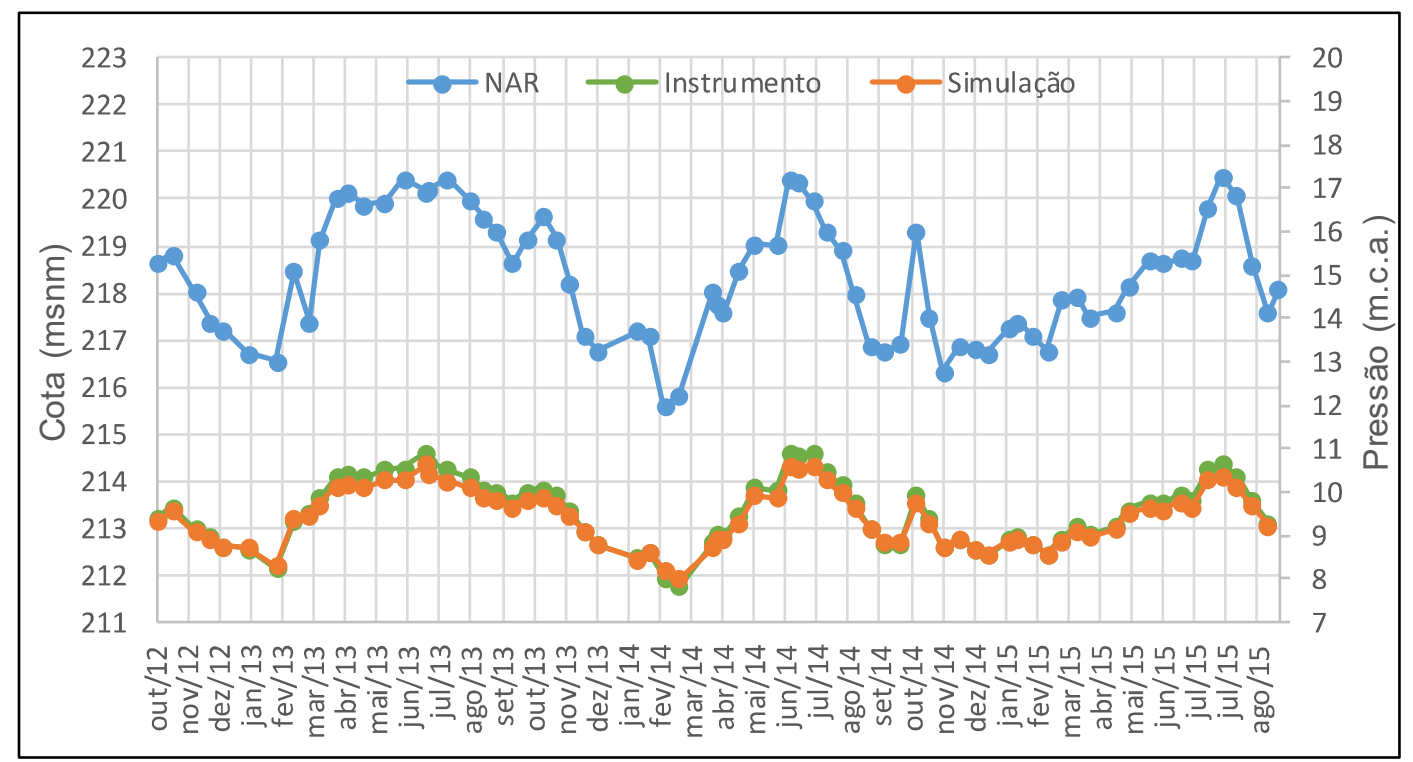

Figura 4.22 - Valores de leitura do PS-L-22 e NAR 


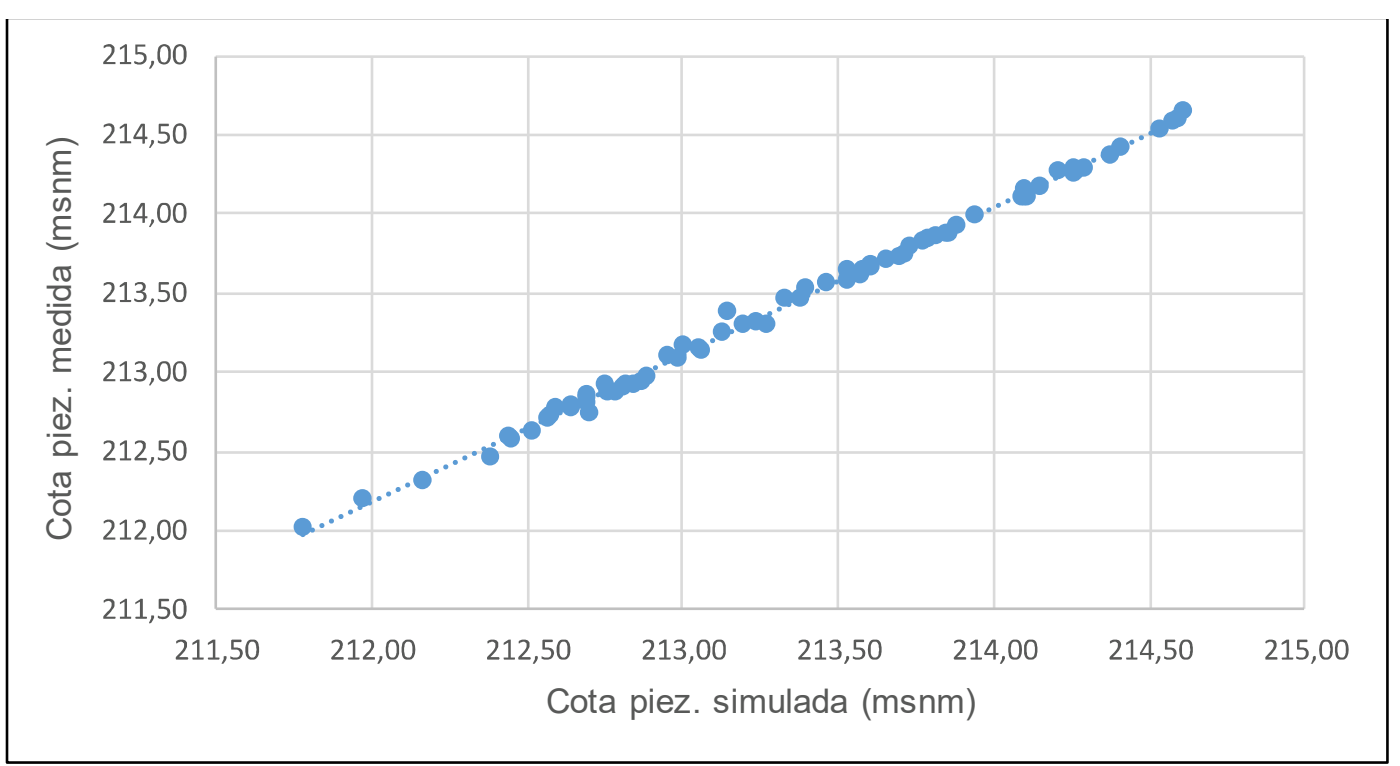

Figura 4.23 - Correlação dos valores lidos e simulados do PS-L-22

Tabela 4.8 - Resultados da correlação entre valores lidos e simulados do PS-L-22 Erro médio $0,09 \mathrm{~m}$

Coef. Correlação de Pearson (r) 0,99

O PS-L-22 foi o instrumento instalado no saprolito que apresentou melhor correlação e menor erro entre os valores lidos e simulados, isso ocorre pelo fato da utilização de uma condição de contorno adicional na seção.

O nível d'água elevado a jusante diminui o gradiente hidráulico e, consequentemente, o fluxo pela fundação. Assim, a linha freática na fundação sofre um rebaixamento e, mesmo num fluxo permanente, a linha freática no maciço compactado forma uma curva.

Por ser uma seção com pouca altura, a água infiltra apenas na região próxima ao pé do talude de montante, local que a pressão exercida pelo reservatório consegue saturar o maciço compactado e estabelecer um fluxo. No caso de rebaixamento rápido, a curvatura fica mais acentuada devido à dissipação lenta das poropressões. No caso de alteamento rápido ocorre novamente a curvatura invertida, mostrando a lenta saturação em direção ao centro do maciço compactado. A Figura 4.24 mostra um fluxo permanente, Figura 4.25 rebaixamento rápido do NAR e Figura 4.26 alteamento rápido. 


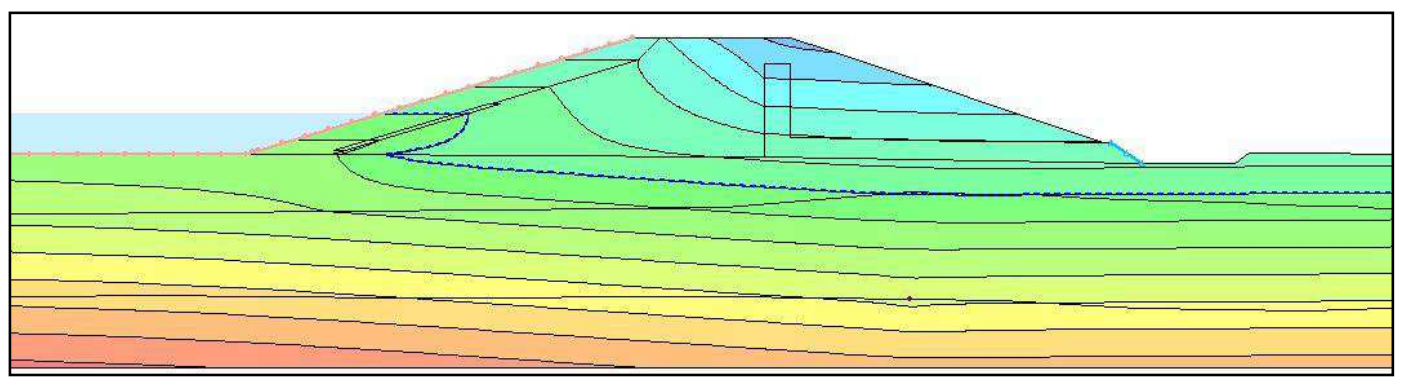

Figura 4.24 - Linha freática para fluxo permanente na seção 132+00

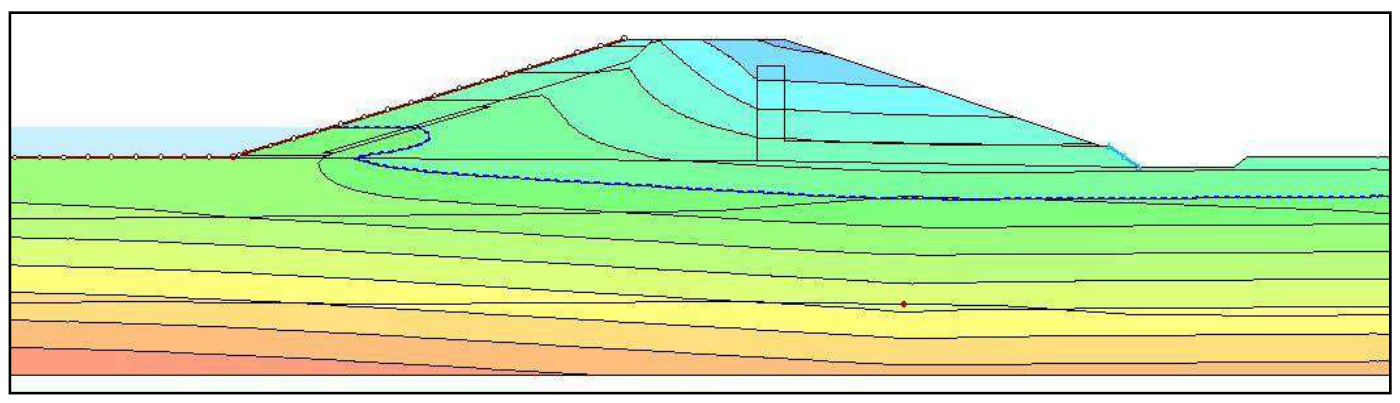

Figura 4.25 - Linha freática para rebaixamento rápido do NAR na seção 132+00

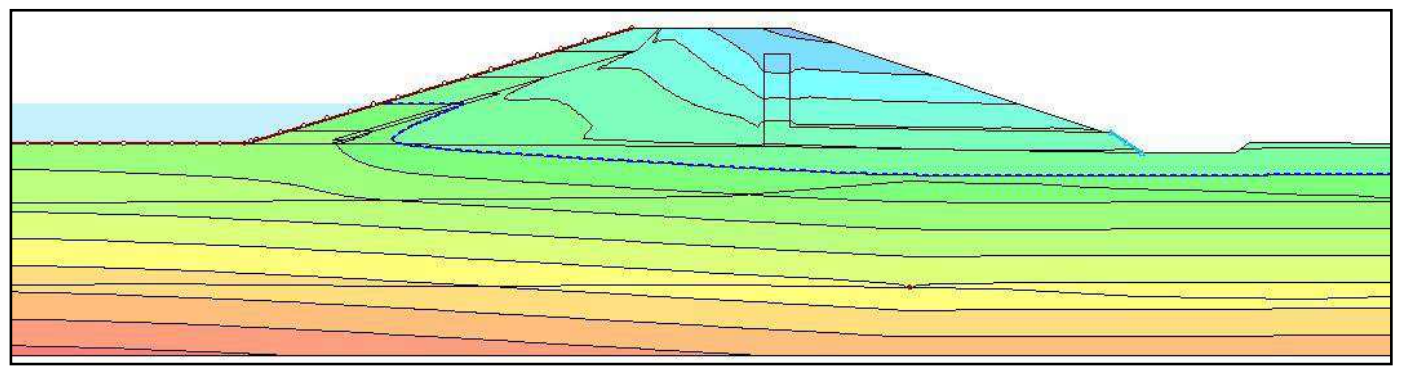

Figura 4.26 - Linha freática para alteamento rápido do NAR na seção 132+00

\section{Seção $135+50$}

A seção $135+50$ é a mais alta das estudadas e com menor camada de solo de fundação. O maciço compactado atinge $10,5 \mathrm{~m}$ e a fundação é composta por uma camada de 4 metros de argila e 3 metros de saprolito, totalizando 7 metros de solo.

A seção é instrumentada com os piezômetros PS-L-23 e PS-L-24 instalados na transição entre o saprolito e o maciço rochoso. A Figura 4.27 mostra uma foto da seção e a Figura 4.28 a seção modelada com os respectivos instrumentos. A Figura 4.29 apresenta os valores lidos e simulados para o PS-L-23 e a Figura 4.30 mostra a correlação entre os valores lidos e simulados e a Tabela 4.9 apresenta detalhes dessa correlação. 


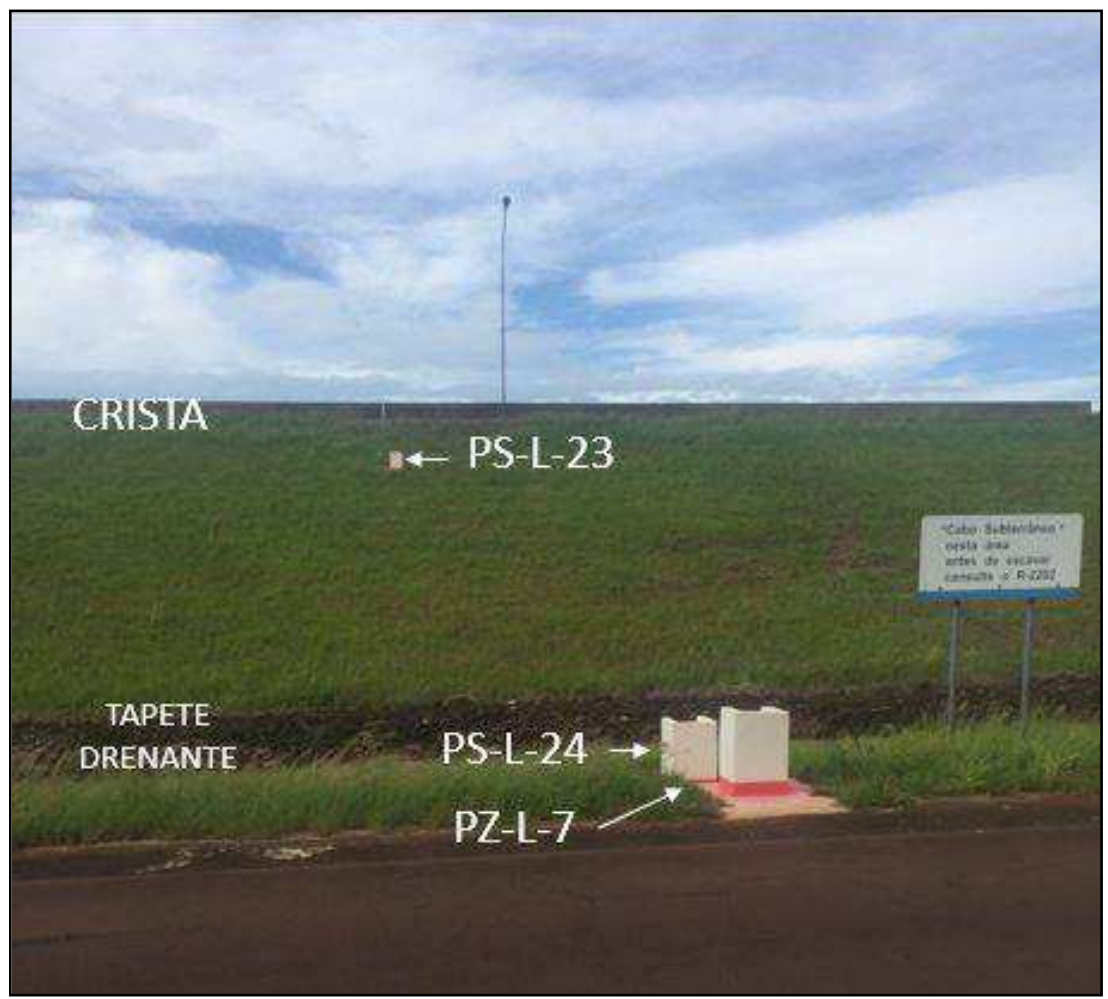

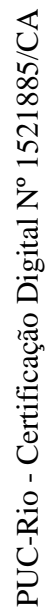

Figura 4.27 - Seção 135+50 da BTME (o autor)

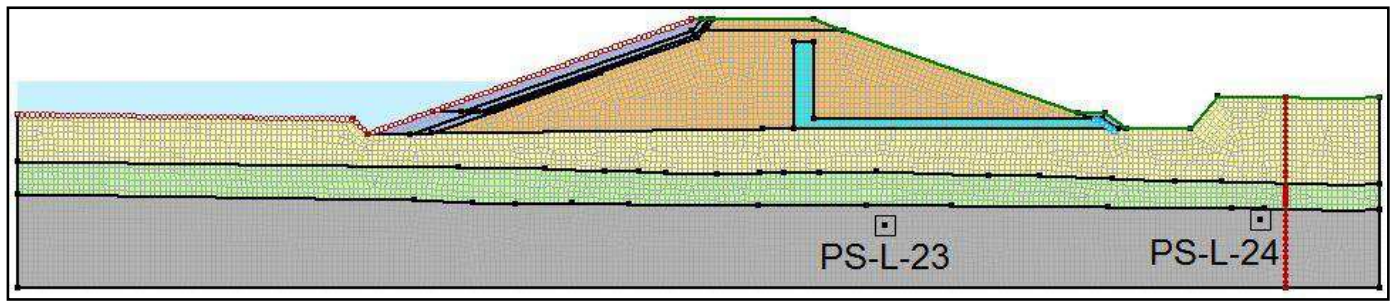

Figura 4.28 - Malha da seção 135+50

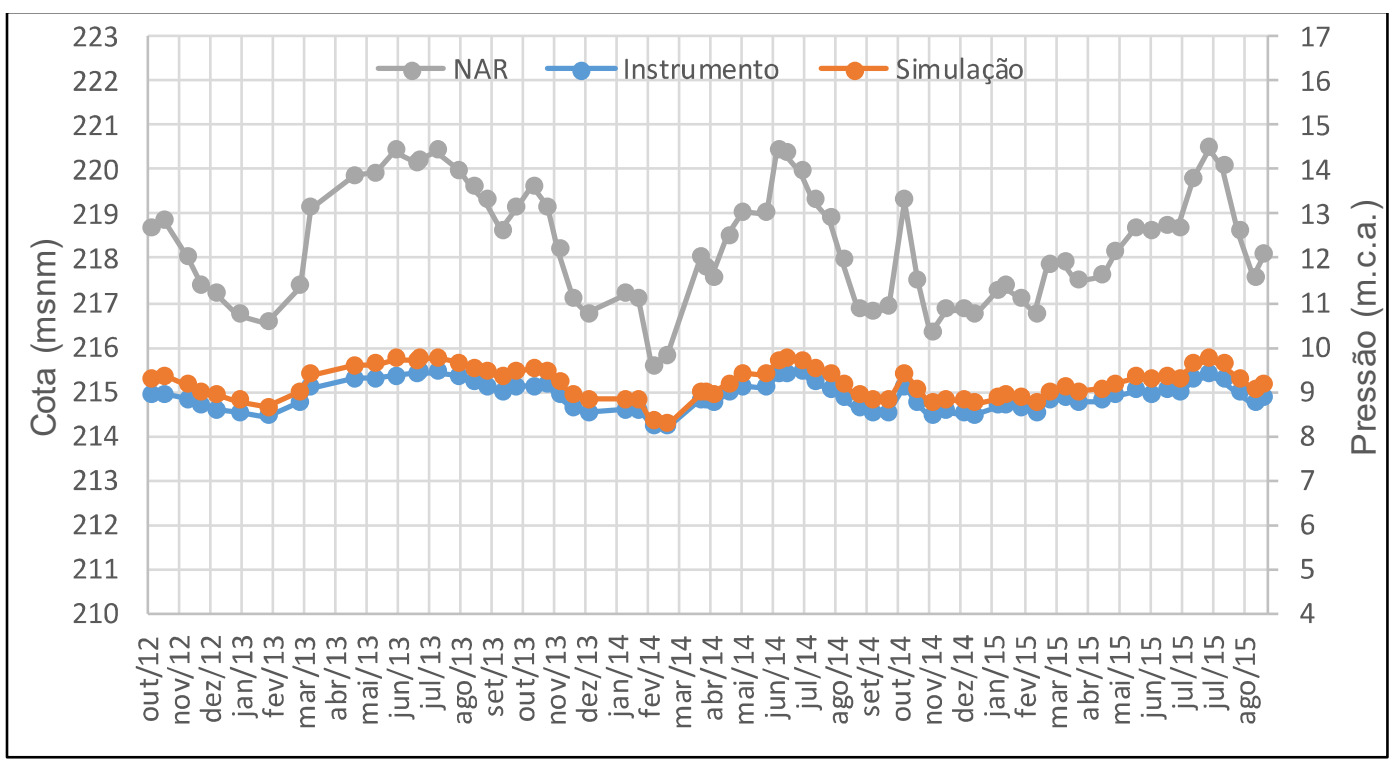

Figura 4.29 - Valores de leitura do PS-L-23 e NAR 


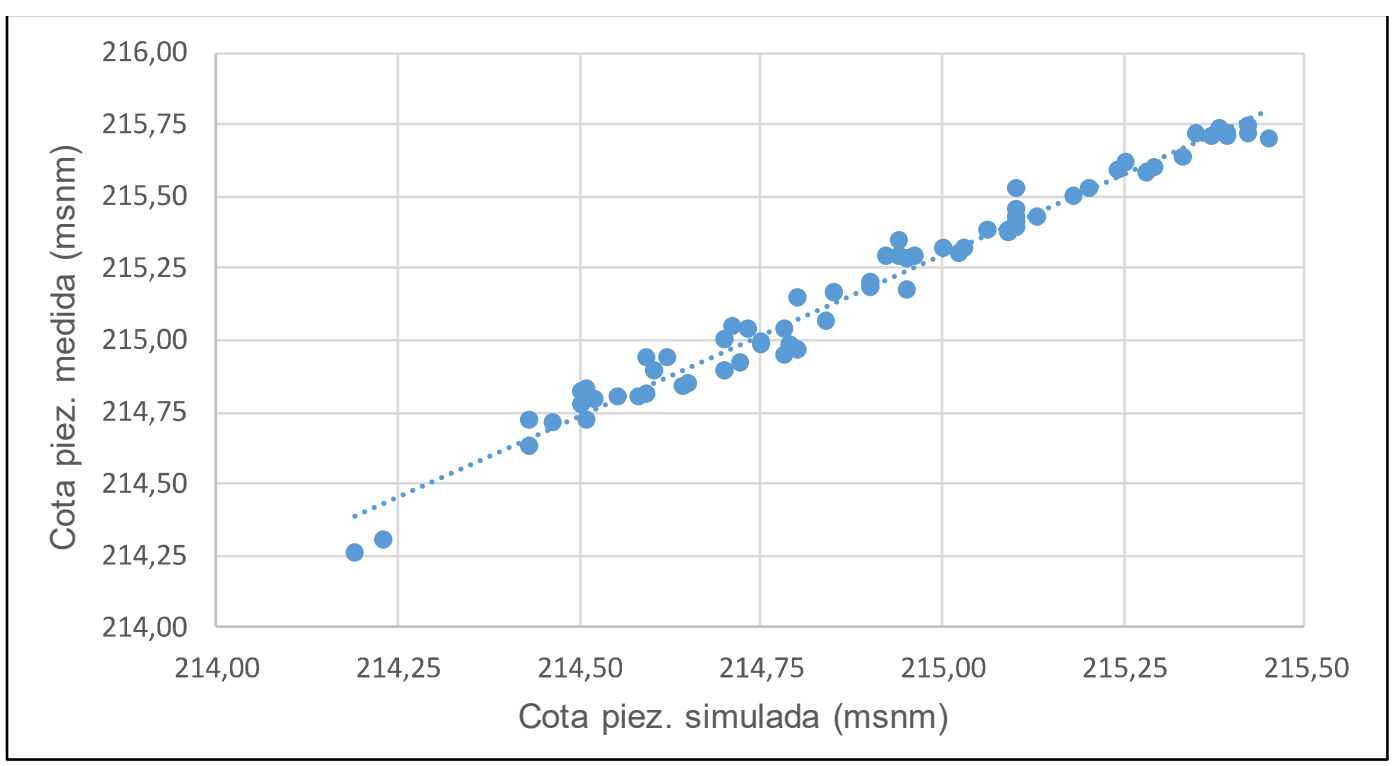

Figura 4.30 - Correlação dos valores lidos e simulados do PS-L-23

Tabela 4.9 - Resultados da correlação entre valores lidos e simulados do PS-L-23 Erro médio $0,28 \mathrm{~m}$

Coef. Correlação de Pearson (r)

Os valores obtidos pela simulação apresentaram forte correlação e um erro médio de $28 \mathrm{~cm}$, valor considerado aceitável. Não houveram valores com discrepâncias notáveis como nos casos anteriores. A comparação entre os valores lidos e simulados do PS-L-24 pode ser vista na Figura 4.31, a correlação entre eles na Figura 4.32 e os resultados da correlação na Tabela 4.10.

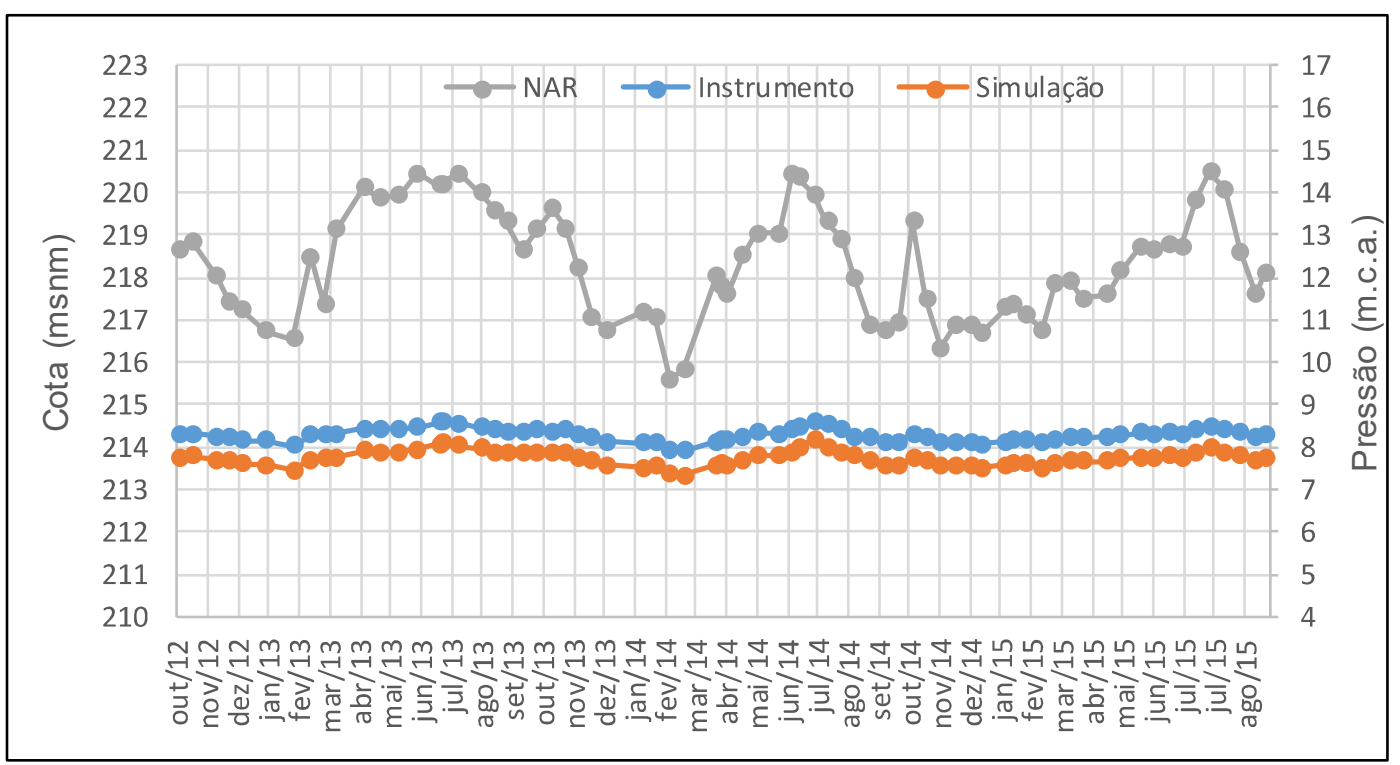

Figura 4.31 - Valores de leitura do PS-L-24 e NAR 


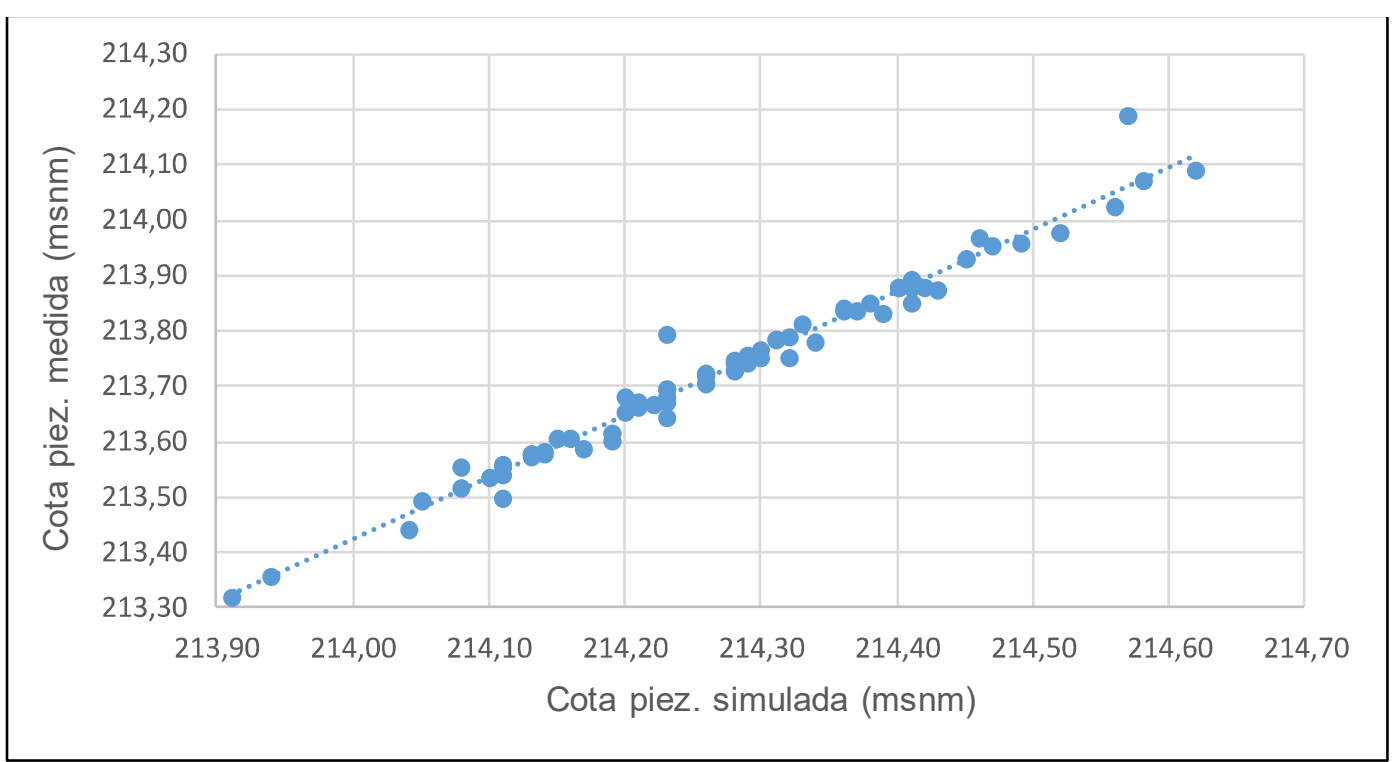

Figura 4.32 - Correlação dos valores lidos e simulados do PS-L-24

Tabela 4.10 - Resultados da correlação entre valores lidos e simulados do PS-L-24 Erro médio $0,54 \mathrm{~m}$

Coef. Correlação de Pearson (r) 0,98

$\mathrm{R}^{2}$ $97,58 \%$

Novamente a simulação apresentou boa correlação com os valores lidos nos instrumentos e o erro ficou dentro de um faixa aceitável.

Nota-se que a variação das cargas dos piezômetros nesta seção é consideravelmente menor que nas seções anteriores, esse comportamento se deve à vazão que passa pela fundação da barragem, onde os instrumentos estão instalados. A seção 135+50 é a que possui menor camada de solo e, consequentemente, o menor fluxo na fundação. Isso também provoca um fluxo maior pelo maciço compactado e eleva a linha freática. A Figura 4.33 mostra os vetores de velocidade para condição de fluxo permanente. Nota-se que são consideravelmente menores que os vetores de velocidade da seção $129+50$ mostrados na Figura 4.13.

Devido à alteração da espessura da camada de solo de fundação e consequente alteração da posição da linha freática, o comportamento para condições de carregamento ou rebaixamento rápido também é alterado. A Figura 4.34 mostra a linha freática para condição de fluxo permanente, Figura 4.35 para descarregamento rápido e Figura 4.36 para carregamento rápido. 


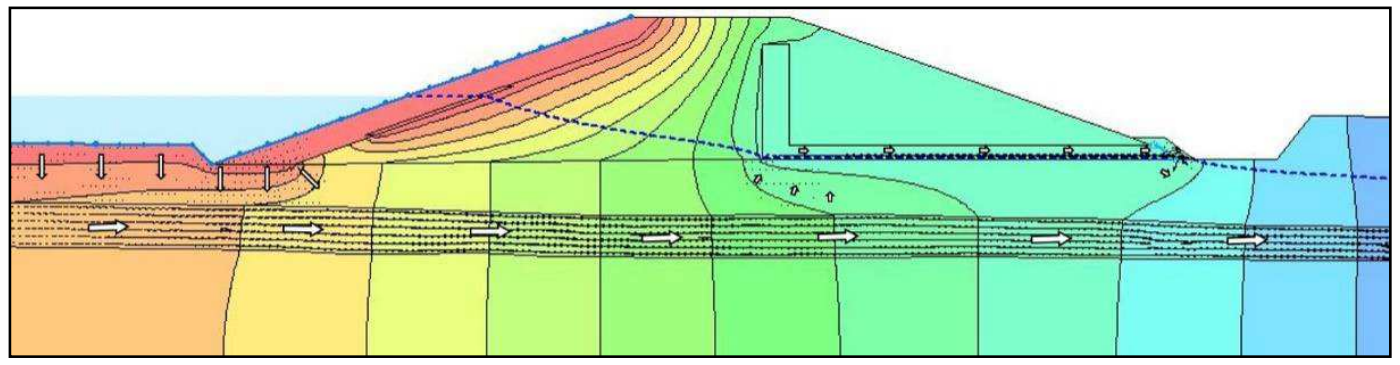

Figura 4.33 - Fluxo através da seção 135+50

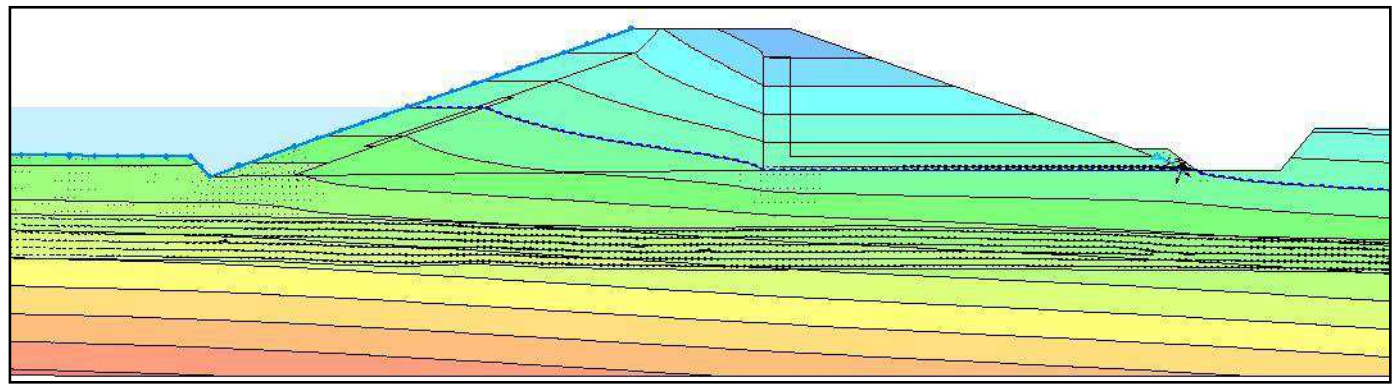

Figura 4.34 - Linha freática para fluxo permanente na seção 135+50

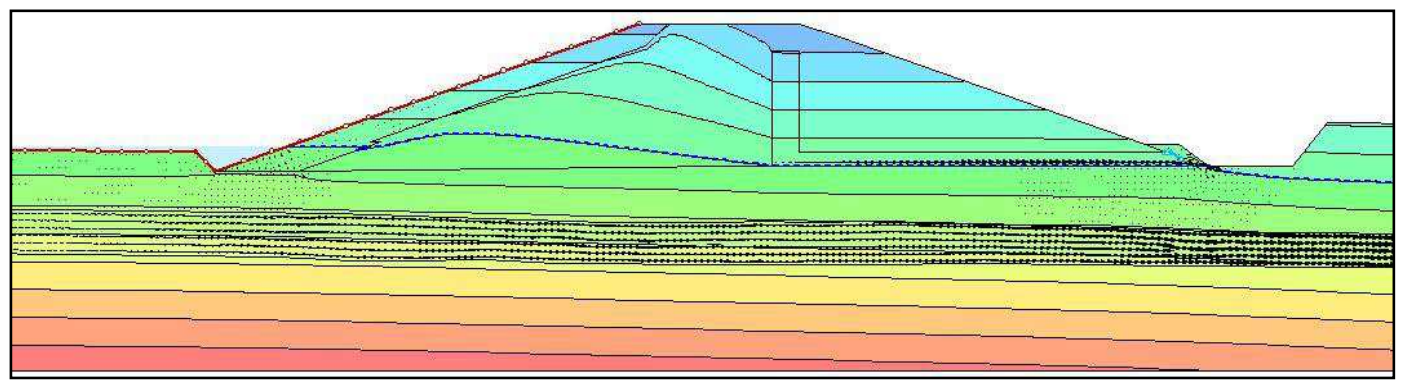

Figura 4.35 - Linha freática para rebaixamento rápido na seção 135+50

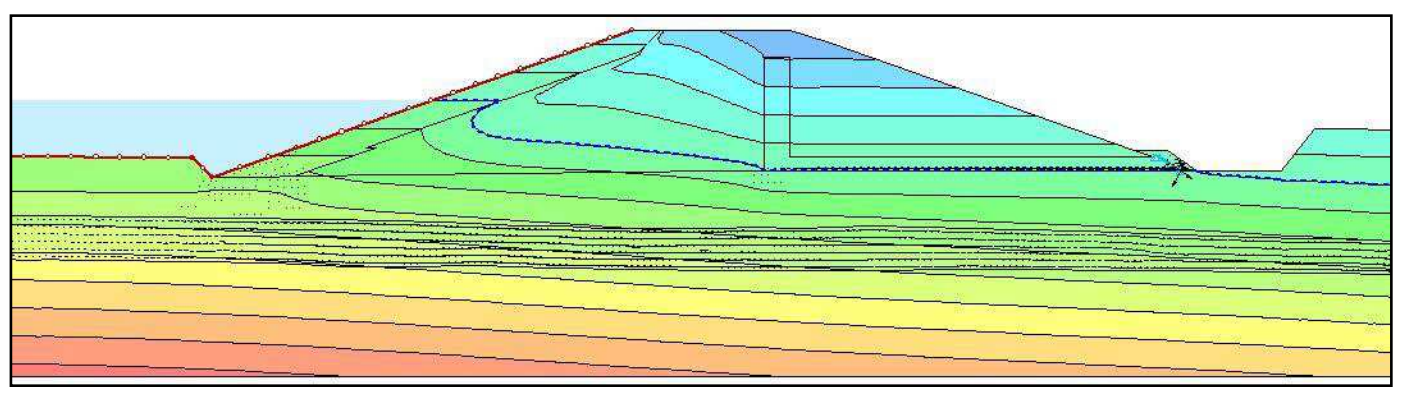

Figura 4.36 - Linha freática para alteamento rápido na seção 135+50

Devido à altura da seção e a espessura da camada de solo na fundação, no fluxo permanente a linha freática atinge o tapete drenante formando uma ligação entre o nível do reservatório e o tapete drenante através do maciço compactado. Quando ocorre rebaixamento rápido, as poropressões diminuem mais rapidamente próximo ao talude de montante, tornando essa ligação entre o nível do reservatório e o tapete drenante uma linha curva. O mesmo ocorre para alteamento rápido, no 
qual a saturação próxima ao talude ocorre mais rapidamente, enquanto no centro do maciço compactado é necessário um tempo maior.

\section{Seção $138+50$}

A mais baixa das seções estudadas possui $5,5 \mathrm{~m}$ de altura $\mathrm{e}$ aproximadamente $8,5 \mathrm{~m}$ de camada de solo na fundação, sendo $5,5 \mathrm{~m}$ de argila e 3 m de saprolito. Uma foto da seção é mostrada na Figura 4.37.

O pé da barragem a montante fica na cota $219 \mathrm{~m}$, cota relativamente alta comparada com as demais seções. Por esse motivo quando o reservatório fica abaixo do nível normal (cota 219 m), a água do reservatório não chega à barragem e não ocorre nenhum fluxo pelo maciço compactado. Como visto no Capítulo 3 , em $70 \%$ do tempo estudado o reservatório ficou abaixo do nível normal, ou seja, durante esse período, eventual fluxo nesta seção ocorria apenas pela fundação.

Os dois piezômetros desta seção estão instalados na argila de fundação próximo ao contato com o saprolito, como pode ser visto na Figura 4.38. A camada de argila possui praticamente o dobro da espessura da camada de saprolito. A Figura 4.39 apresenta os valores lidos e simulados para o PS-L-25, a Figura 4.40 mostra a correlação entre os valores lidos e simulados e a Tabela 4.11 apresenta detalhes dessa correlação.

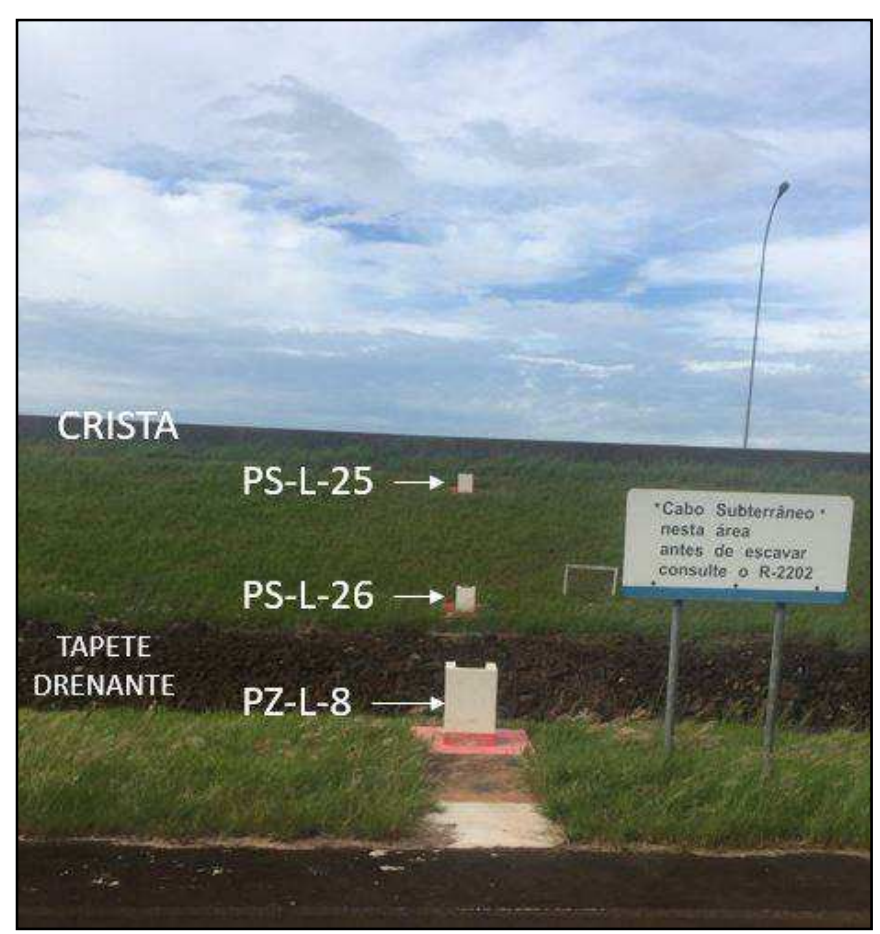

Figura 4.37 - Seção 138+50 da BTME 


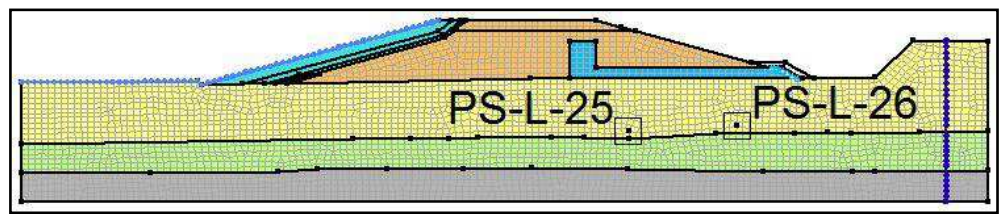

Figura 4.38 - Malha da seção $138+50$

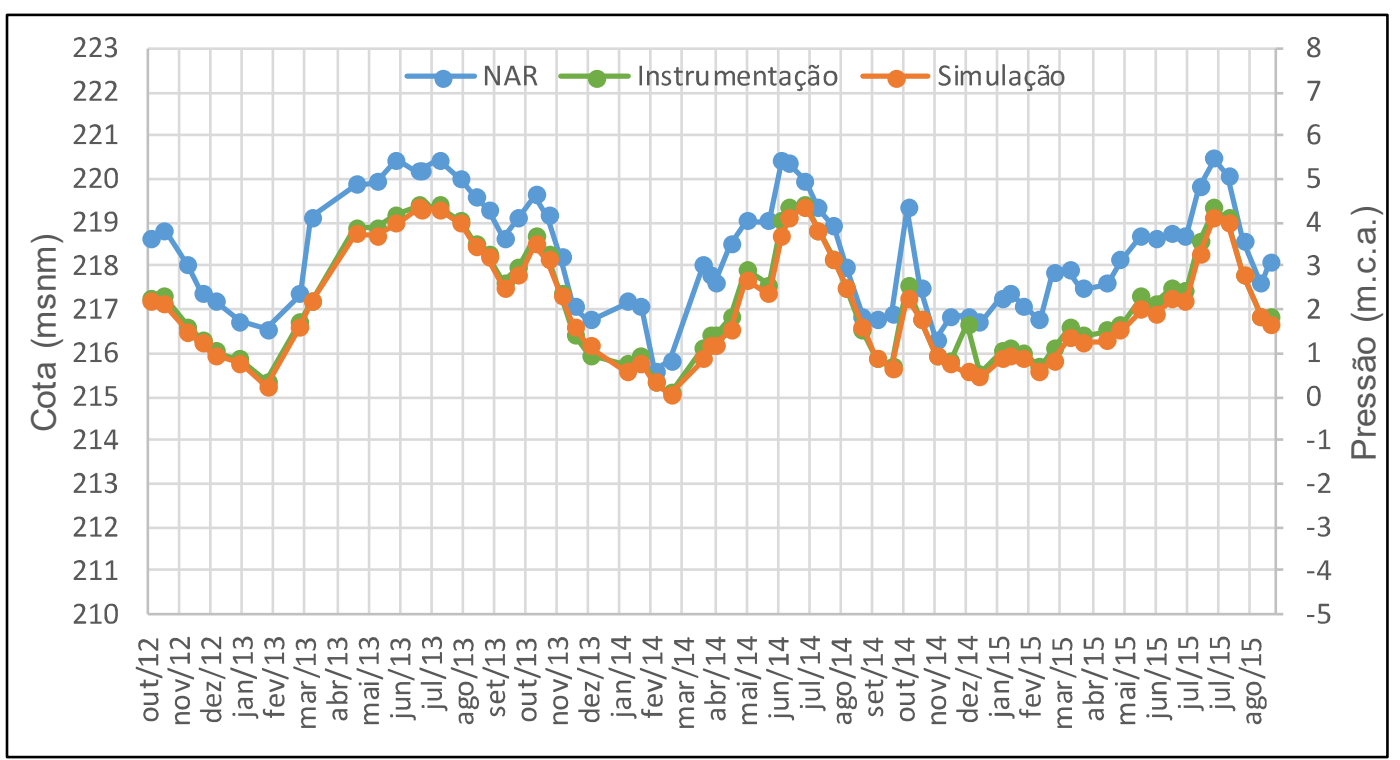

Figura 4.39 - Valores de leitura do PS-L-25 e NAR

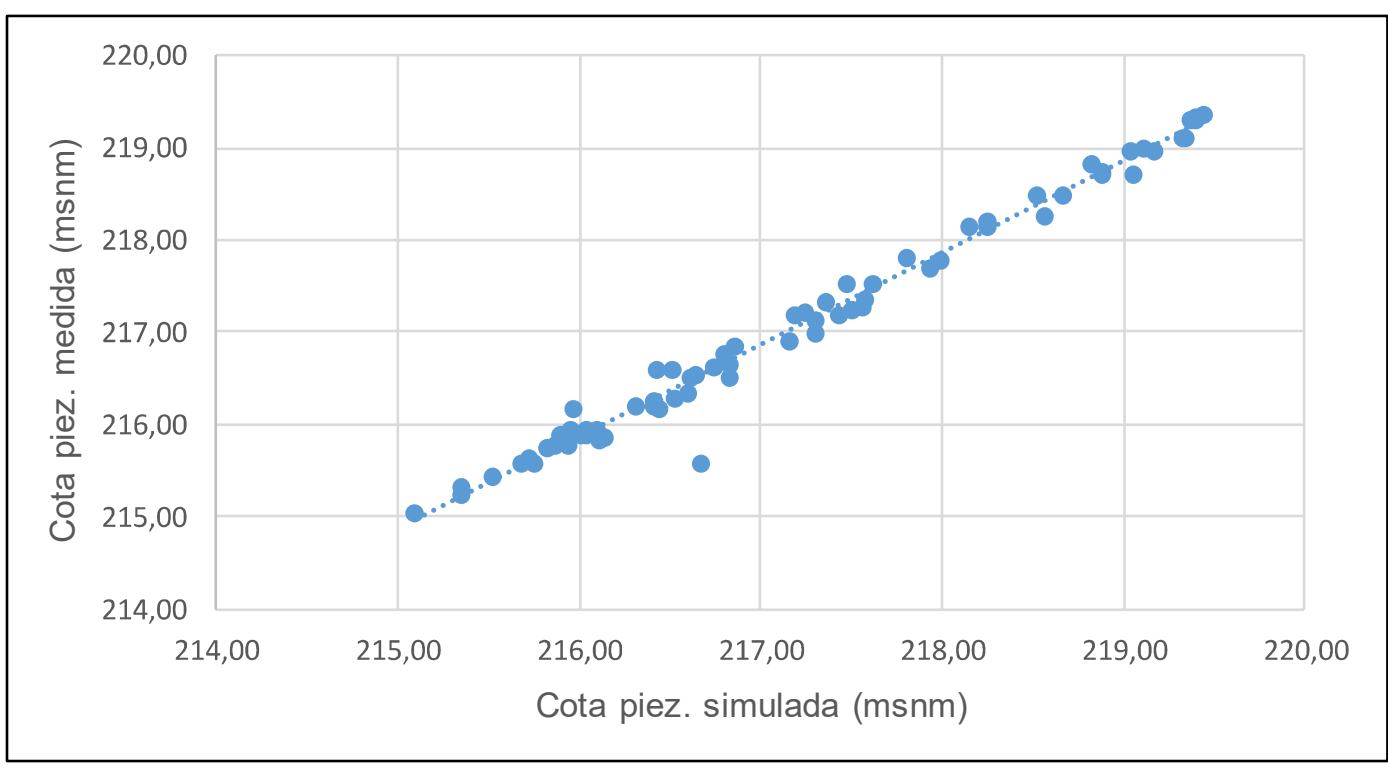

Figura 4.40 - Correlação dos valores lidos e simulados do PS-L-25

Tabela 4.11 - Resultados da correlação entre valores lidos e simulados do PS-L-25 Erro médio $0,15 \mathrm{~m}$

Coef. Correlação de Pearson (r) 
Nota-se que neste caso a instrumentação apresenta boa correlação, porém não responde imediatamente ao comportamento do reservatório, existe uma defasagem de tempo entre a variação do NAR e a resposta do piezômetro explicada no Item 3.4.1. Isso faz com que no caso de rebaixamentos rápidos, a cota medida no instrumento fique próxima ao nível do reservatório, pois a argila leva um tempo para dissipar as poropressões e reduzir a cota piezométrica. O mesmo fenômeno ocorre também no PS-L-26 e pode ser visto na Figura 4.41. A Figura 4.42 mostra a correlação entre os valores lidos e simulados e a Tabela 4.12 apresenta detalhes dessa correlação.

A faixa de variação das poropressões nesses piezômetros é consideravelmente maior que nas seções anteriores. Como o nível d'água fica a maior parte do tempo somente na fundação, não ocorre perda de carga pela barragem e a variação de poropressões é predominantemente hidrostática.

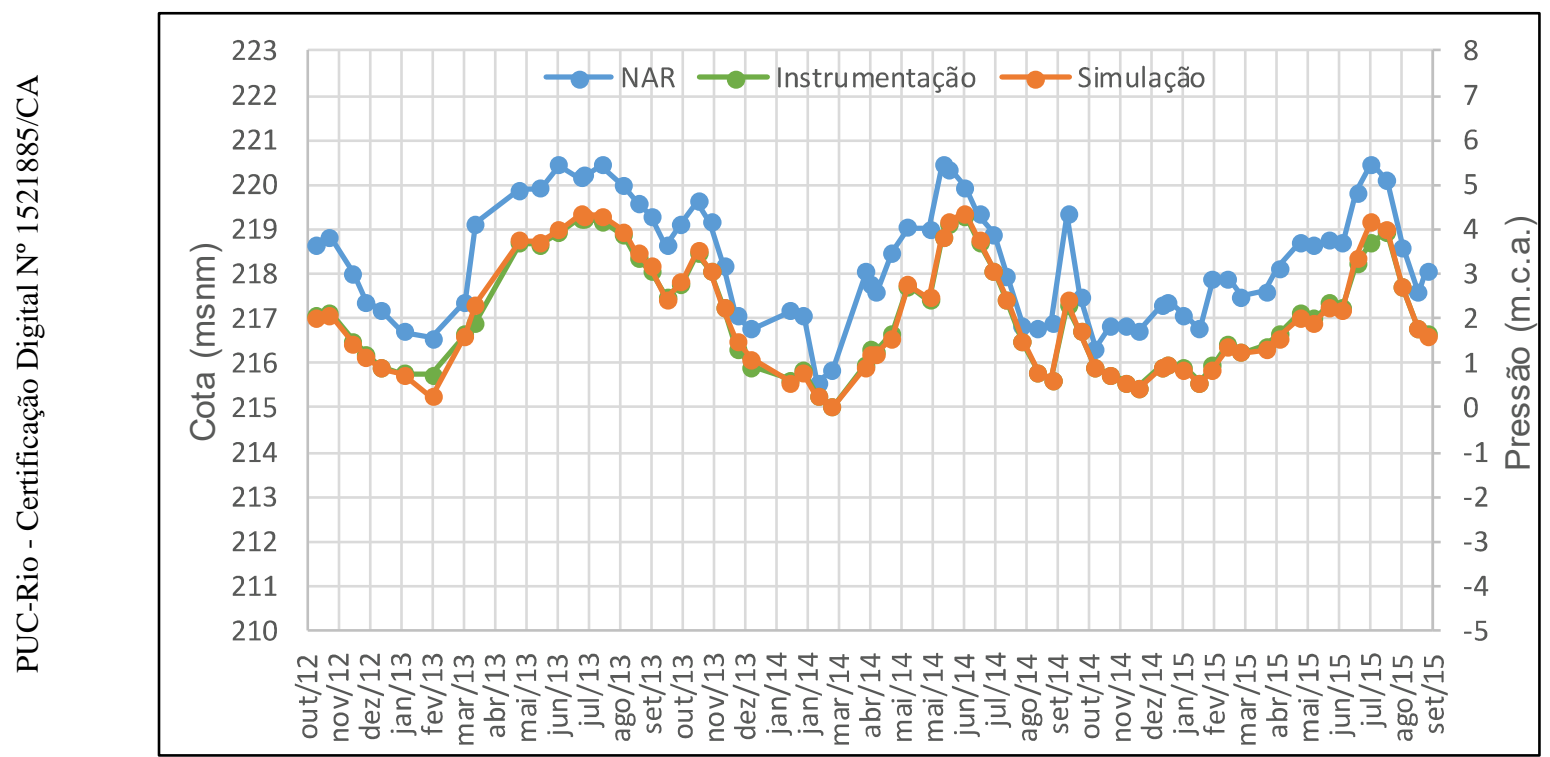

Figura 4.41 - Valores de leitura do PS-L-26 e NAR 


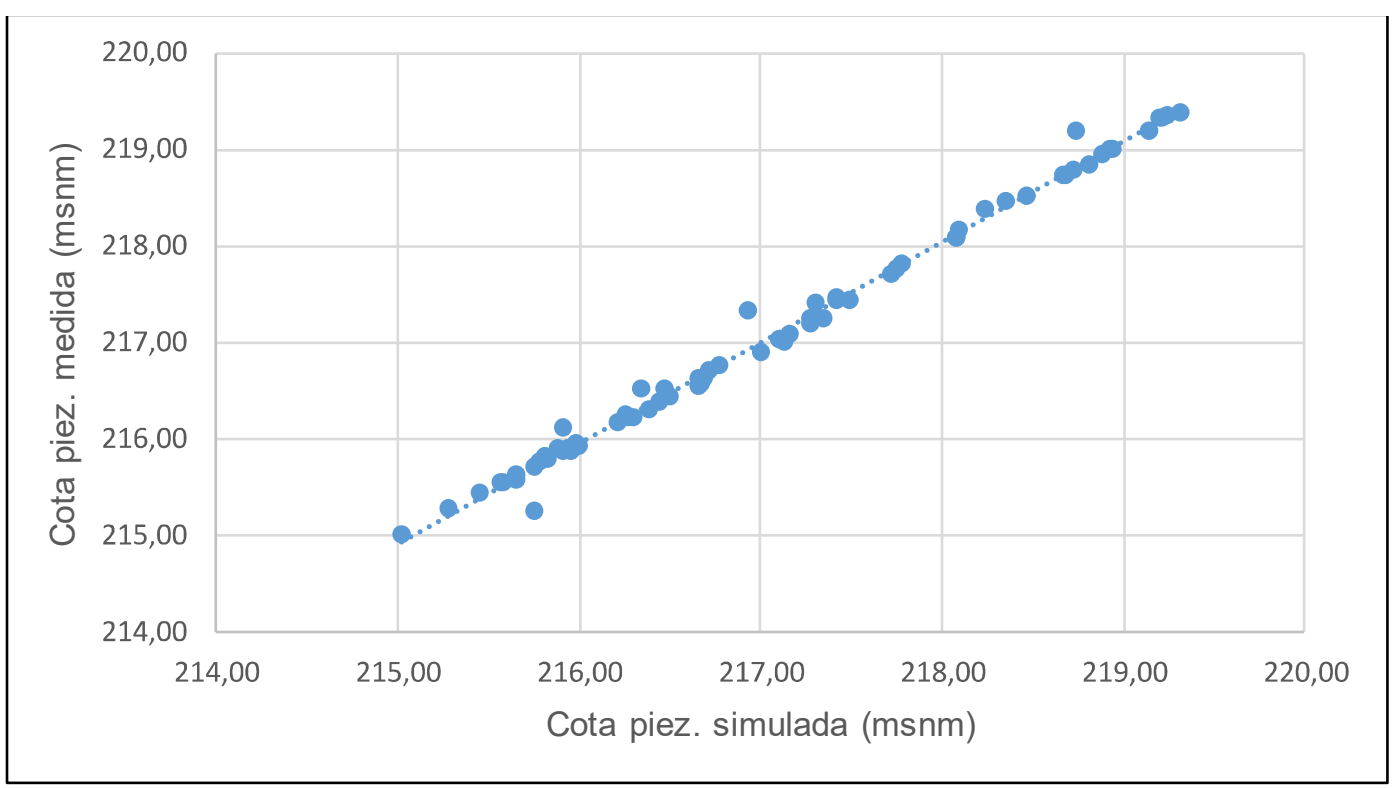

Figura 4.42 - Correlação dos valores lidos e simulados do PS-L-26

Tabela 4.12 - Resultados da correlação entre valores lidos e simulados do PS-L-26 Erro médio 0

Coef. Correlação de Pearson (r) $\quad 0,99$

O fenômeno típico de estudo para casos de rebaixamentos rápidos não ocorre nesta seção. Como o reservatório atinge apenas uma pequena altura do corpo da barragem, em caso de rebaixamento rápido as poropressões se dissipam rapidamente. A Figura 4.43 mostra a seção $138+50$ em condição de fluxo permanente, nota-se que a linha freática entra no maciço compactado próximo ao pé da barragem, mas bem próximo dali já passa para a fundação.

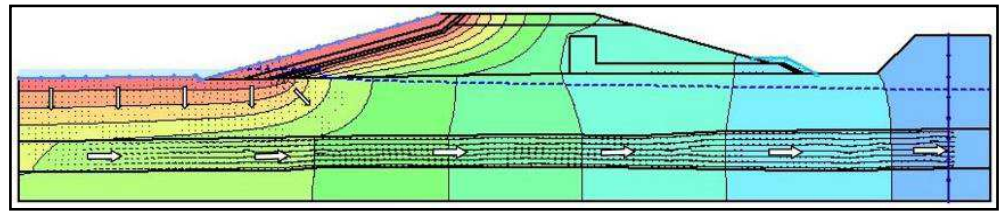

Figura 4.43 - Fluxo através da seção 138+50

\section{3}

\section{Análise de Estabilidade}

O programa (SLOPE/W) disponibiliza diversos métodos de equilíbrio limite para cálculos de estabilidade, entre eles: Morgenstern-Price, Spencer, Janbu, Janbu Generalizado, Bishop, Sarma, entre outros. 
Considerando que o maciço compactado da barragem é homogêneo e as camadas de fundação possuem parâmetros semelhantes, para as análises foi utilizado o método de Bishop, desenvolvido para superficies de rupturas circulares e que apresenta resultado semelhante aos dos métodos de Morgenstern-Price e Spencer, com menos esforço computacional. Foram realizadas, também, análises estatísticas do fator de segurança do talude de jusante.

As poropressões no maciço foram obtidas da análise de fluxo realizada anteriormente (SEEP/W). Nas condições de fluxo permanente se obteve um fator de segurança a montante e/ou jusante, de acordo com a análise, e no fluxo transiente foram obtidos fatores de segurança diários para montante e jusante.

Para os critérios de resistência, o maciço compactado e a fundação foram consideradas saturados, condição considerada mais crítica, onde não há contribuição da sucção mátrica para a resistência ao cisalhamento.

\subsection{1}

\section{Parâmetros de Resistência (c'e $\left.\Phi^{\prime}\right)$}

Ao contrário da permeabilidade os parâmetros de resistência não podem ser calibrados com base em instrumentação, foram utilizados então os parâmetros obtidos nos ensaios no período de investigação e construção.

Para as análises a longo prazo (fluxo permanente) utilizaram-se os parâmetros efetivos obtidos dos ensaios consolidados e drenados (CD). Para as análises de fluxo transiente, que consideram o rebaixamento e alteamento do reservatório, foram utilizados os parâmetros efetivos dos ensaios saturados consolidados e não drenados $\left(\mathrm{CU}_{\text {sat }}\right)$, pois, a baixa permeabilidade do material comparado com as velocidades de carregamento/descarregamento do maciço fazem com que ele se comporte de modo não drenado.

Como não foram realizados ensaios de resistência com o material do dreno, para o dreno e enrocamento foram adotados os valores conservadores usados em projeto. A Tabela 4.13 apresenta os valores utilizados para cada tipo de material. 
Tabela 4.13 - Parâmetros de Resistência

\begin{tabular}{ccccc}
\hline \multirow{2}{*}{ Material } & \multicolumn{2}{c}{$\mathrm{CU}_{\text {sat }}$} & \multicolumn{2}{c}{$\mathrm{CD}$} \\
& $\mathrm{c}^{\prime}(\mathrm{kPa})$ & $\Phi^{\prime}\left({ }^{\mathrm{o}}\right)$ & $\mathrm{c}^{\prime}(\mathrm{kPa})$ & $\Phi^{\prime}\left({ }^{\circ}\right)$ \\
\hline Argila compactada & 36 & 29,3 & 54 & 27,4 \\
Argila da fundação & 10 & 23 & 0 & 25 \\
Dreno & 0 & 40 & 0 & 40 \\
Enrocamento & 0 & 40 & 0 & 40 \\
Saprolito da fundação & 20 & 25 & 20 & 25 \\
\hline
\end{tabular}

\subsection{2}

\section{Análise Determinística do Período Proposto}

Foram calculados no total 2212 fatores de segurança para cada seção, sendo 1106 para o talude de montante e 1106 para o talude de jusante. Os cálculos usaram o output das análises de fluxo realizadas anteriormente, obtendo assim fatores de segurança diários.

\section{Seção $129+50$}

Como já visto, a seção $129+50$ possui $9,5 \mathrm{~m}$ de altura e o pé do talude a montante fica na cota $215,50 \mathrm{~m}$. A Figura 4.44 mostra os fatores de segurança para superficie de ruptura crítica ao longo do período proposto para o talude de montante e de jusante, no mesmo gráfico é inserido o nível do reservatório para melhor entendimento do comportamento da barragem.

O FS a montante apresenta correlação positiva com o NAR, ou seja, quanto mais baixo o NAR menor o FS no talude de montante, e vice-versa, isso ocorre devido à contribuição do peso do reservatório para a estabilidade do talude. Conforme o NAR é reduzido e chega próximo a cota do pé da barragem essa pressão exercida pelo reservatório passa a ter menor influência e o FS varia em menor proporção.

Entre janeiro e março de 2014, quando o NAR fica abaixo do pé da barragem (cota 215,5 m aproximadamente), o fenômeno se inverte e a redução do nível d'água passa a aumentar o FS, isso ocorre, pois, o nível freático sai do maciço compactado, passa para fundação e, conforme é rebaixado na fundação aumenta a resistência da camada superficial de solo. 


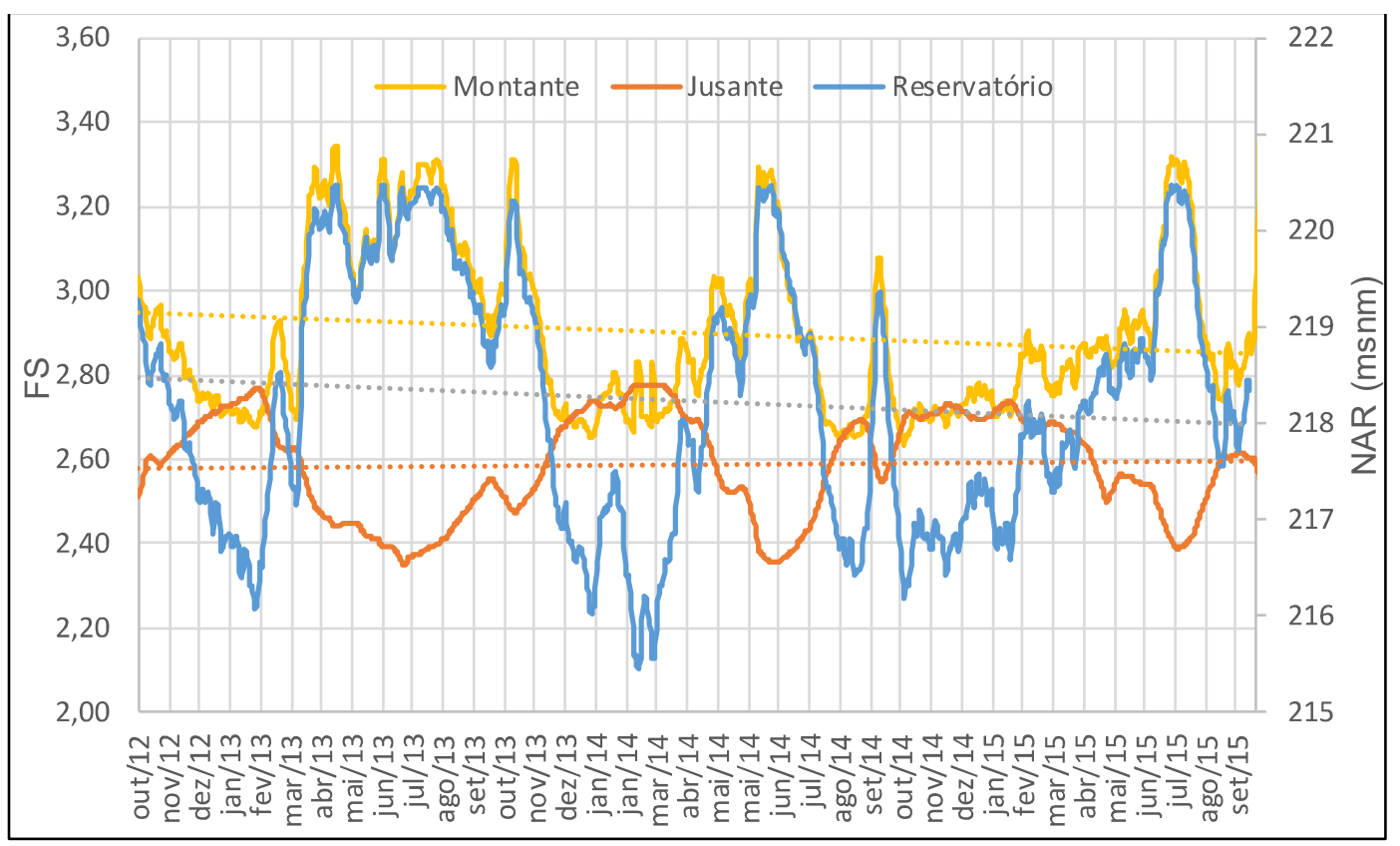

Figura 4.44 - Fatores de segurança para a seção 129+50

O menor FS no talude de montante foi de 2,63 na data de 31 de outubro de 2014, quando o NAR estava na cota $216,20 \mathrm{~m}, 70 \mathrm{~cm}$ acima do pé da barragem. O fator determinante para o menor FS não ocorrer com o NAR no pé da barragem é a velocidade de rebaixamento do nível d'água. Nesta ocasião o NAR saiu da cota $219,37 \mathrm{~m}$ no dia 07 de outubro e atingiu a cota $216,20 \mathrm{~m}$ no dia 31 de outubro, variando $3,17 \mathrm{~m}$ em 24 dias e atingindo uma velocidade média de descarregamento de 13,2 cm por dia, maior velocidade de descarregamento registrada no período estudado.

O FS a jusante apresenta correlação negativa com o NAR, ou seja, quando o NAR aumenta a pressão exercida pelo mesmo e o aumento das poropressões na fundação contribuem para a desestabilização do talude de jusante. Isso faz com que os FS de montante e jusante sejam espelhados, quando um aumenta o outro diminui e vice-versa, porém com taxas de alteração diferentes. O FS a montante varia numa faixa maior e com maior velocidade, pois o talude está diretamente em contato com a pressão do reservatório. Essa tensão aplicada é dissipada no maciço e exerce menor influência no FS do talude de jusante. O menor FS para o talude de jusante é de 2,35 e ocorre no mês de junho de 2013 , período no qual o reservatório ficou acima da cota 220 por vários dias.

Os fatores de segurança a montante e a jusante passam a ter o mesmo comportamento quando o NAR fica abaixo do pé da barragem e a linha freática 
atinge apenas a fundação, nesse caso, o rebaixamento da linha freática contribui para o aumento de ambos.

As linhas de tendência, exibidas na Figura 4.44 pelas linhas pontilhadas, permitem reafirmar o comportamento dos fatores de segurança em relação ao NAR. No período estudado, o NAR e o FS a montante tiveram a mesma tendência a redução enquanto o FS a jusante apresentou uma leve tendência a aumentar.

As Figuras 4.45 e 4.46 mostram as superficies de ruptura obtidas para os fatores de segurança críticos a montante e jusante, respectivamente. Para os demais fatores de segurança, as superficies de ruptura não apresentam grandes variações, tanto para jusante como a montante visto que, a base da superficie de ruptura na fundação fica próximo à divisa das camadas de argila e saprolito.

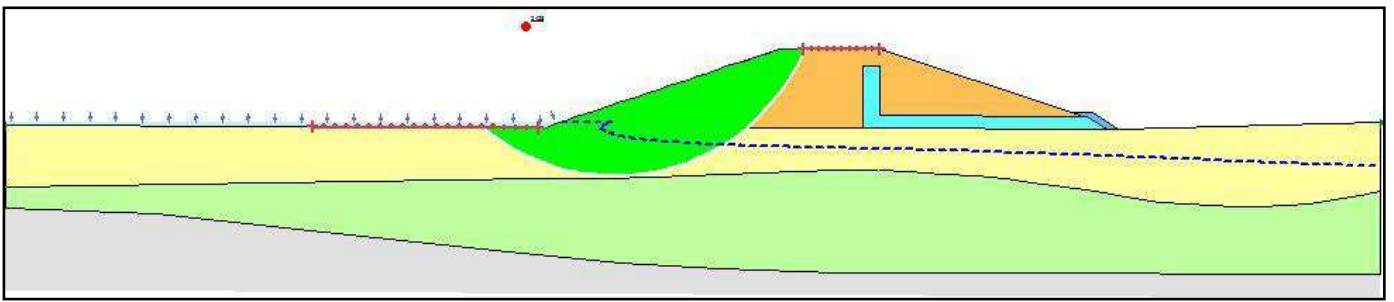

Figura 4.45 - Superfície de ruptura a montante na seção 129+50

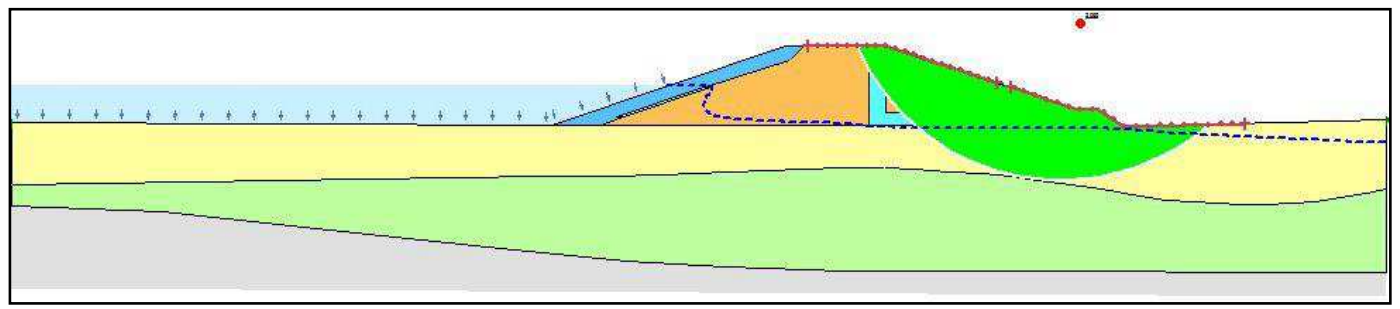

Figura 4.46 - Superfície de ruptura a jusante na seção 129+50

\section{Seção $132+00$}

Seção com aproximadamente $9 \mathrm{~m}$ de altura sendo o pé do talude de jusante na cota $216,20 \mathrm{~m}$. A Figura 4.47 mostra os fatores de segurança obtidos para o talude de montante e jusante ao longo do período estudado.

Assim como na seção $129+50$, o FS do talude de montante apresenta correlação positiva com o NAR, enquanto o FS do talude de jusante apresenta correlação negativa. O aumento do FS a montante devido ao rebaixamento do NAR abaixo do pé da barragem ocorre com mais frequência nesta seção. Isso acontece devido a menor altura da seção e, consequentemente, a maior quantidade de tempo 
que o talude fica sem incidência de água do reservatório. Tal comportamento é evidenciado, por exemplo, no período entre janeiro e março de 2014.

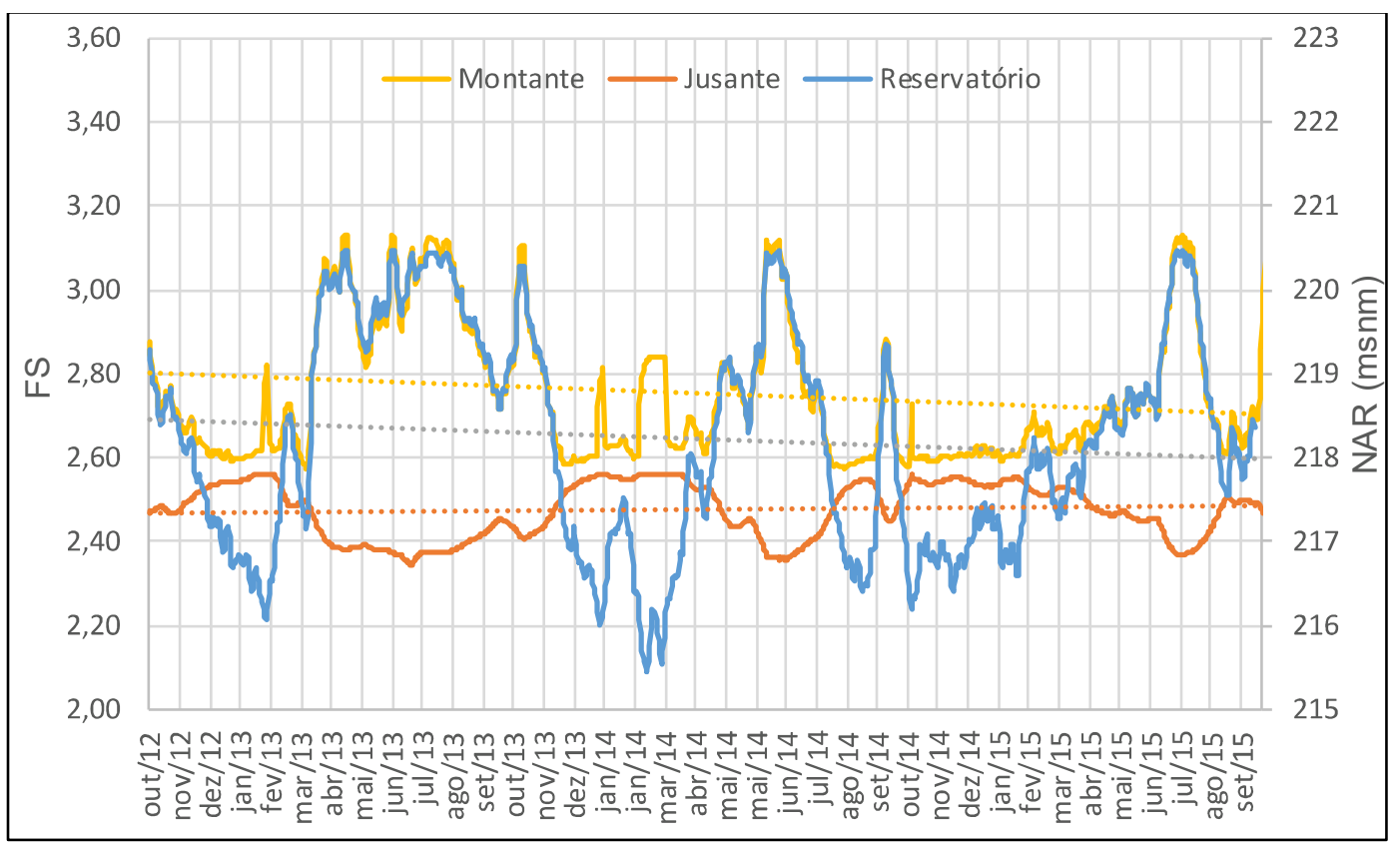

Figura 4.47 - Fatores de segurança para a seção 132+00

O menor FS do talude de montante é 2,57 em um caso de rebaixamento rápido no mês de março de 2013. No talude de jusante o menor FS encontrado foi de 2,35 e, semelhante ao talude da seção 129+50, ocorreu no mês de junho de 2013 quando o NAR permaneceu acima da cota 220 por vários dias.

As linhas de tendência do NAR e do FS do talude de montante se mostraram praticamente paralelas, mostrando que existe uma relação direta entre ambos, enquanto a linha de tendência do FS do talude de jusante apresentou uma elevação praticamente imperceptível e a faixa de variação do mesmo diminuiu em relação à seção 129+50. Isso mostra que o FS do talude de jusante é menos dependente do NAR. Isso ocorre devido ao FS do talude de jusante variar principalmente em função das poropressões exercidas na fundação, já que a jusante do dreno vertical o maciço compactado permanece seco. Note-se também que nesta seção a camada de solo na fundação é menor e, portanto, a variação das poropressões também é menor.

As Figuras 4.48 e 4.49 mostram as superficies de ruptura para os fatores de segurança críticos dos taludes de montante e jusante respectivamente, a superfíc ie de ruptura a montante varia sempre com a base da superfície próximo a região de 
transição entre a argila e saprolito da fundação, a superficie de ruptura a jusante não sofre alterações devido variação do NAR.

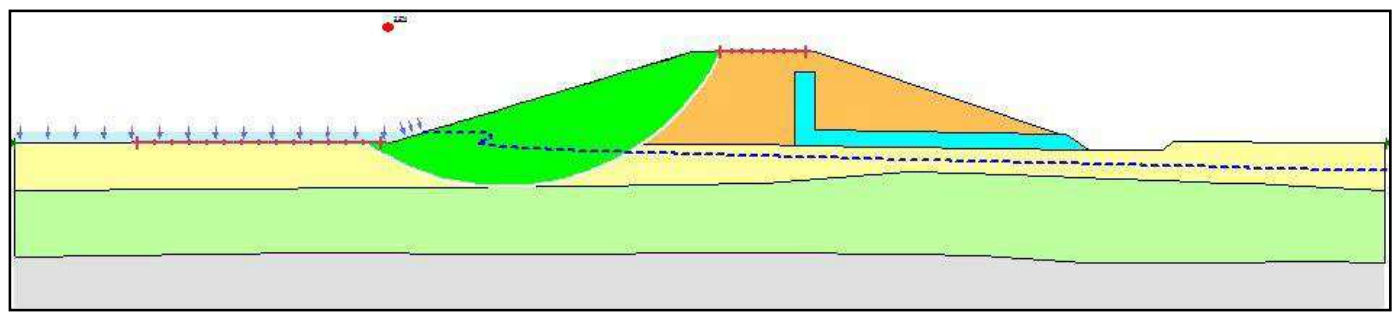

Figura 4.48 - Superfície de ruptura a montante na seção 132+00

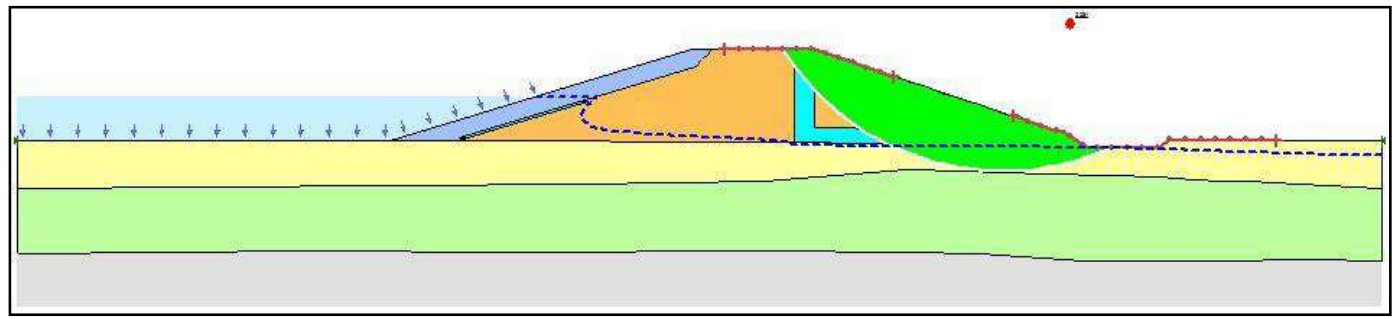

Figura 4.49 - Superfície de ruptura a jusante na seção 132+00

\section{Seção $135+50$}

A seção $135+50$ é a mais alta das estudadas, com 10,5 m de altura o pé do talude de montante fica na cota $214,40 \mathrm{~m}$. A Figura 4.50 apresenta os fatores de segurança obtidos para os taludes de montante e jusante ao longo do período estudado.

O comportamento do FS do talude de montante é semelhante ao das seções anteriores, porém, em nenhum momento o NAR fica abaixo do pé da barragem e, portanto, não ocorre aumento do FS com o rebaixamento do nível d'água na fundação. Quando o reservatório atinge cotas mais baixas e fica próximo ao pé do talude o fator de segurança é pouco influenciado pela alteração do NAR. Ressaltase que em nenhum momento chega a inverter o comportamento, como ocorre na seção $129+50$ e $132+00$. 


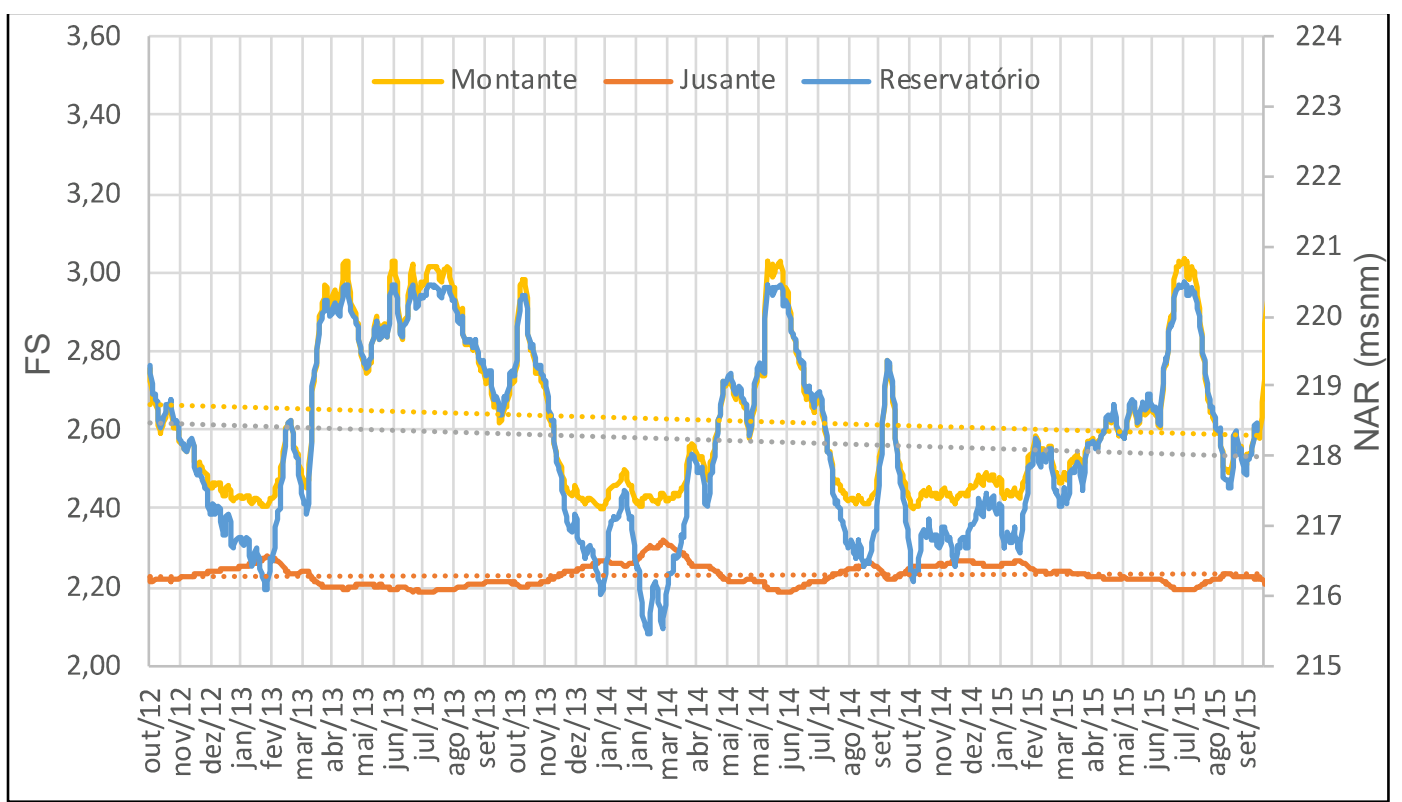

Figura 4.50 - Fatores de segurança para a seção 135+50

O menor FS do talude de montante do período é de 2,40 e novamente para o dia 31 de outubro de 2014, data que o reservatório atingiu a cota 216,20 após um rebaixamento rápido.

Por possuir uma camada pouco espessa de solo na fundação, nesta seção a variação das poropressões medidas no saprolito é a menor registrada e, consequentemente, a variação do FS do talude de jusante também é pequena. O menor FS obtido para este caso foi de 2,11 em 29 de junho de 2014, data na qual o NAR teve um pico atingindo cotas acima da $220 \mathrm{~m}$.

As linhas de tendências do NAR e do FS do talude de montante novamente são paralelas, neste caso por questão de visualização ficaram congruentes, enquanto a linha de tendência do FS do talude de jusante permanece na horizontal, mostrando maior independência do NAR.

As superficies de ruptura para os taludes de montante e jusante são mostradas nas Figuras 4.51 e 4.52 respectivamente.

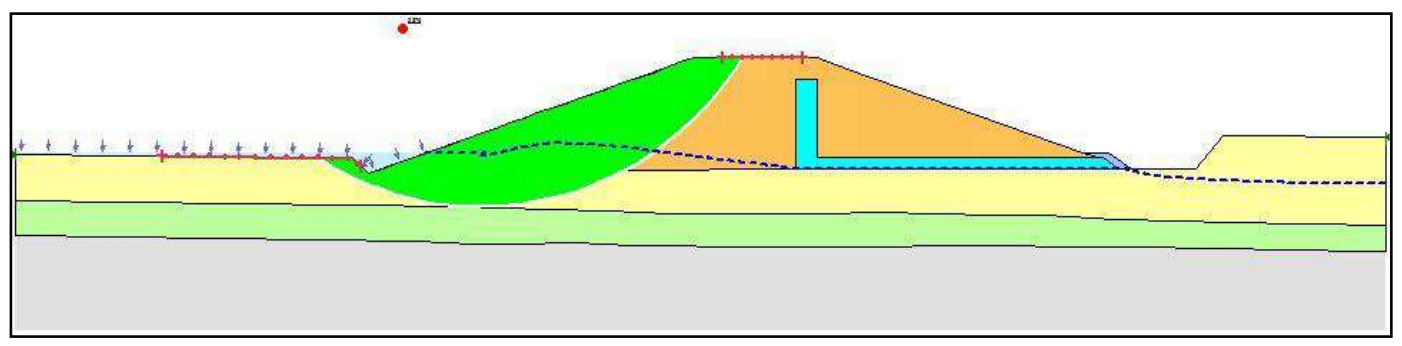

Figura 4.51 - Superfície de ruptura a montante na seção 135+50 


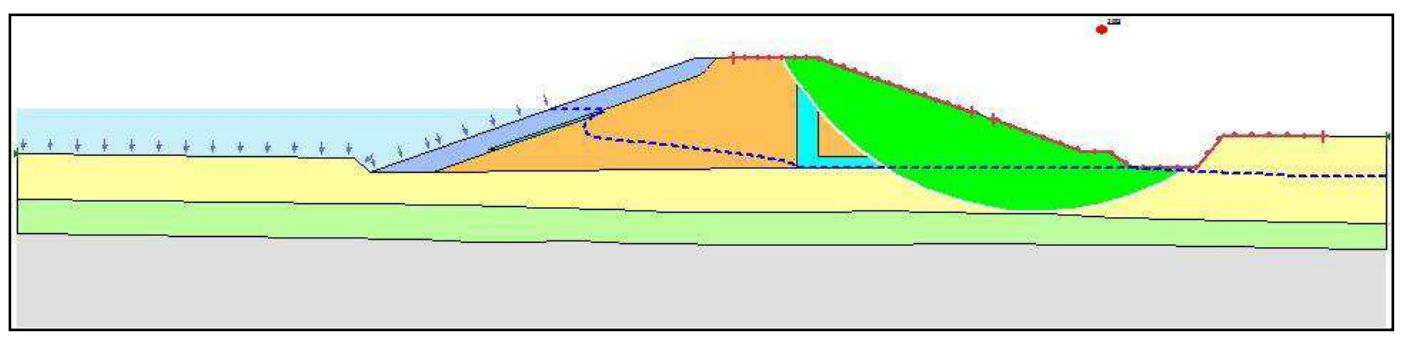

Figura 4.52 - Superfície de ruptura a jusante na seção 135+50

A base da superficie de ruptura, tanto para montante como para jusante, fica novamente na área de transição entre a argila e o saprolito.

\section{Seção $138+50$}

Por ser a menor das seções estudadas e com o pé do talude em uma cota elevada, esta seção apresenta comportamento ao longo do período diferente das demais. A Figura 4.53 apresenta os fatores de segurança obtidos para os taludes de montante e jusante ao longo do período estudado.

O NAR passa a ter influência considerável nos fatores de segurança apenas quando está acima da cota $219 \mathrm{~m}$, cota do pé da barragem. Como a maior parte do tempo o reservatório fica abaixo dessa cota, é possível notar que em vários momentos ambos fatores de segurança ficam constantes ou com pequenas variações.

Quando o NAR fica acima da cota 219 m, o FS do talude de montante passa a acompanhar o comportamento do NAR, enquanto o FS do talude de jusante varia de maneira mais lenta e inversa ao comportamento do NAR.

O menor FS do talude de montante foi 2,54 e ocorreu no mês de julho de 2014, quando o NAR estava no pé da barragem enquanto ocorria um rebaixamento do reservatório. 


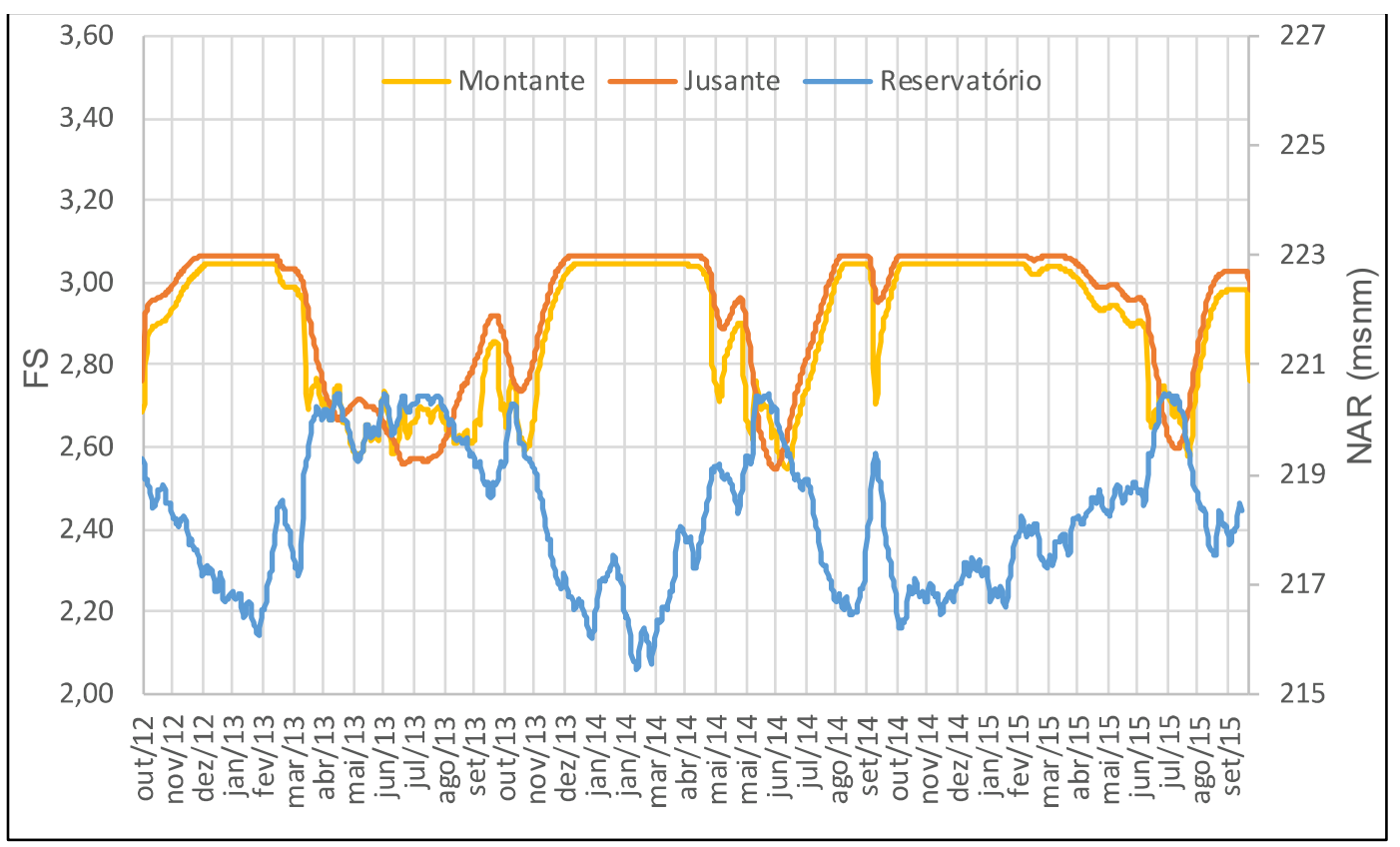

Figura 4.53 - Fatores de segurança para a seção 138+50

O menor FS do talude de jusante foi 2,55 e ocorreu no dia 29 de junho de 2014, na mesma ocasião que ocorreu a situação crítica na seção $135+50$, quando o NAR teve um pico acima da cota $220 \mathrm{~m}$.

As Figuras 4.54 e 4.55 mostram as superficies de ruptura para FS crítico a montante e jusante respectivamente.

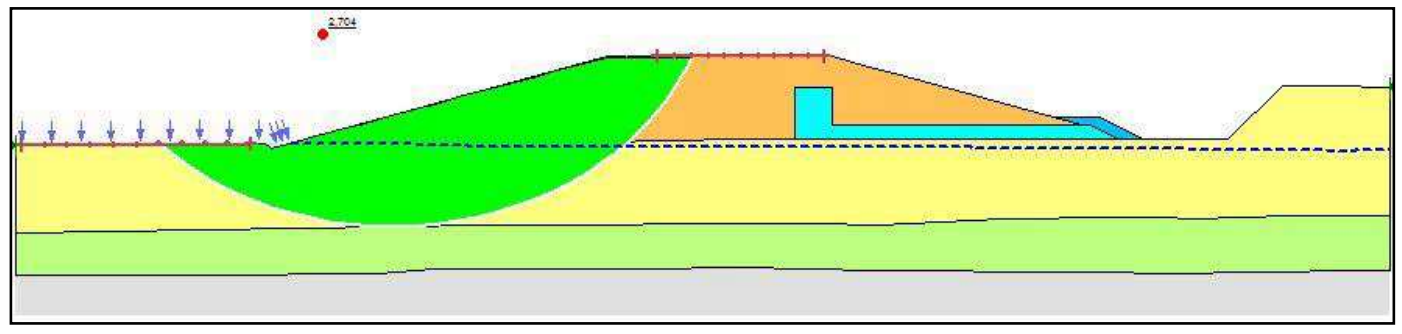

Figura 4.54 - Superfície de ruptura a montante na seção 138+50

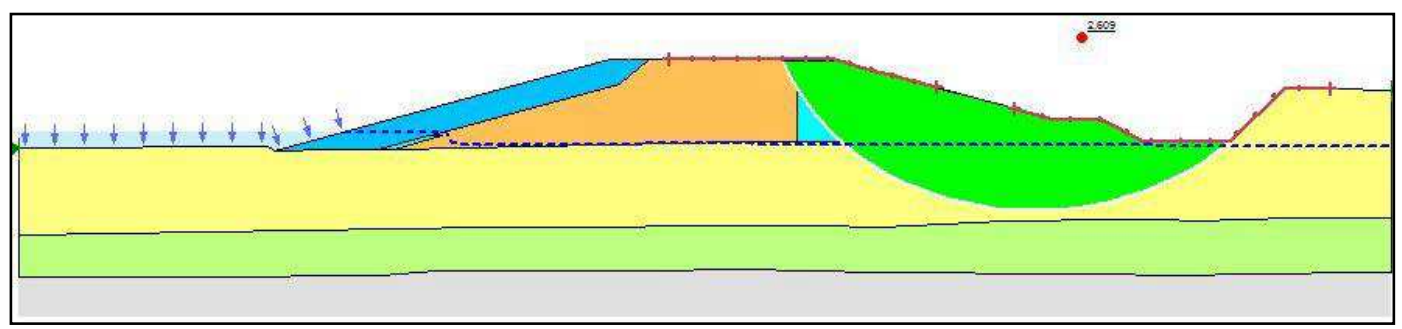

Figura 4.55 - Superfície de ruptura a jusante na seção 138+50

A Tabela 4.14 apresenta os fatores de segurança mínimos e as ocasiões que eles ocorreram. 
Tabela 4.14 - Fatores de segurança mínimos no período estudado

\begin{tabular}{ccccc}
\cline { 2 - 5 } $129+50$ & \multicolumn{2}{c}{ FS mínimo } & - montante & \multicolumn{2}{c}{ FS mínimo } & - jusante \\
\cline { 2 - 5 } $132+00$ & 2,63 & Outubro/2013 & 2,35 & Junho/2013 \\
$135+50$ & 2,57 & Março/2013 & 2,35 & Junho/2013 \\
$138+50$ & 2,40 & Outubro/2014 & 2,11 & Junho/2014 \\
\hline
\end{tabular}

\subsection{3}

\section{Análise Probabilística}

Métodos probabilisticos podem ser aplicados nas análises geotécnicas para complementar as análises de estabilidade determinísticas. Esses métodos tratam as incertezas que existem no meio geotécnico e complementam a informação do fator de segurança com uma probabilidade de ruptura associada às incertezas.

Mafioleti (2016) aplicou o algoritmo FORM (First Order Reliability Method) para avaliação probabilística da estabilidade do talude de jusante da seção $122+00$ da BTME sob regime permanente. A referida seção está localizada a aproximadamente 750 metros da área estudada e o material do núcleo da barragem é o mesmo em ambas, a principal diferença é a altura da seção e a existência de bermas na seção $122+00$ que não existem nas seções estudadas nesta pesquisa.

De maneira simplificada, este estudo aplicou o método de primeira ordem e segundo momento proposto por Sandroni e Sayão (1992) para estimar a variância, $\mathrm{V}[\mathrm{FS}]$, e o índice de confiabilidade, $\beta$, do FS do talude de jusante sob regime permanente.

Foram realizadas duas análises para cada seção em estudo, na primeira considerou-se como varáveis aleatórias a coesão efetiva (c'), o ângulo de atrito efetivo (ф') do corpo da barragem e o ângulo de atrito efetivo (ф') da fundação. $O$ NAR, nível d'água a jusante, peso específico e parâmetros dos materiais foram consideradas determinísticos, conforme as análises determinísticas anteriores.

Na segunda análise o NAR passou a ser uma variável aleatória e foi utilizada a variação do nível durante o período proposto para estudo anteriormente (outubro/12 à outubro/15) para obtenção da média, coeficiente de variação, desvio padrão e variância. Esta análise visou mostrar a importância dos parâmetros, especialmente do NAR. 


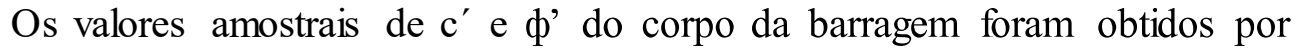
Mafioleti (2016) a partir de 48 ensaios triaxiais consolidados drenados realizados na época da obra e descritos nos relatórios de Itaipu.

Os valores para as variáveis da fundação foram obtidos de 9 ensaios triaxia is também consolidados e drenados. Nas três envoltórias de resistência traçadas com os 9 ensaios da argila da fundação, a coesão efetiva foi nula e por esse motivo foi adotado de forma determinística $c^{\prime}=0$. Por possuir poucos resultados de ensaios das argilas de fundação, foi adotado um coeficiente de variação típico para o ângulo de atrito efetivo sugerido por Sayão et al. (2012).

As médias, desvios padrão, variância e coeficiente de variação das variáveis aleatórias são mostrados na Tabela 4.15.

Tabela 4.15 - Dados estatísticos das variáveis aleatórias

\begin{tabular}{ccc}
\hline Argila do corpo da barragem & Argila da fundação \\
\hline $\mathrm{c}^{\prime}(\mathrm{kPa})$ & $\Phi^{\prime}\left({ }^{\circ}\right)$ & $\Phi^{\prime}\left({ }^{\circ}\right)$
\end{tabular}

$\begin{array}{cccc}\text { Média } & 55,5 & 27,3 & 31,7 \\ \text { Coef. de variação } & 0,24 & 0,05 & 0,1 \\ \text { Desvio padrão } & 13,49 & 1,39 & 1,78 \\ \text { Variância } & 182,10 & 1,93 & 3,17\end{array}$

\section{Seção 129+50}

Para análise com valor do NAR determinístico foi obtida a média no período proposto para estudo, entre outubro de 2012 e outubro de 2015. Neste período o valor médio foi $218,24 \mathrm{~m}$, cerca de $0,75 \mathrm{~m}$ abaixo do nível de operação normal. A Tabela 4.16 apresenta os cálculos para obtenção da variância do FS a partir do FS determinístico igual a 2,26. Em seguida a Equação 4.1 calcula o índice de confiabilidade do FS.

Tabela 4.16 - Cálculo da variância do FS da seção 129+50 com NAR determinístico

\begin{tabular}{ccccccc} 
& Média (X) & $\Delta \mathrm{X}$ & $\Delta \mathrm{FS}$ & $\frac{\Delta X}{\Delta F S}$ & $\mathrm{~V}[\mathrm{X}]$ & $\mathrm{V}[\mathrm{FS}]$ \\
\cline { 2 - 7 } c' (maciço) & 55,5 & 5,6 & 0,029 & 0,005 & 182,1 & $4,97 \mathrm{E}-3$ \\
$\Phi^{\prime}$ (maciço) & 27,3 & 2,7 & 0,009 & 0,003 & 1,93 & $2,10 \mathrm{E}-5$ \\
$\Phi^{\prime}$ (fundação) & 31,7 & 3,2 & 0,830 & 0,262 & 3,2 & $2,18 \mathrm{E}-1$ \\
\hline
\end{tabular}




$$
\beta=\frac{E[F S]-1}{\sigma[F S]} \quad \rightarrow \quad \frac{2,26-1}{0,22^{2}}=2,67
$$

Analisando a Figura 2.5, com o gráfico proposto por Sandroni e Sayão (1992), é possível afirmar que para $\beta=2,67$ a probabilidade de ruptura (Pr) é de aproximadamente $0,3 \%$.

$\mathrm{Na}$ análise que considera o NAR como variável aleatória foi realizado procedimento semelhante ao anterior, porém, usou-se o NAR diário no período entre outubro de 2012 e outubro de 2015 para determinação da média, desvio padrão e variância. A Tabela 4.17 apresenta os cálculos para obtenção da variância do FS a partir do FS determinístico de 2,26. Em seguida a Equação 4.2 calcula o índice de confiabilidade do FS.

Tabela 4.17 - Cálculo da variância do FS na seção 129+50 com NAR como variável aleatória

\begin{tabular}{|c|c|c|c|c|c|c|}
\hline & Média (X) & $\Delta \mathrm{X}$ & $\Delta \mathrm{FS}$ & $\frac{\Delta X}{\Delta F S}$ & $\mathrm{~V}[\mathrm{X}]$ & $\mathrm{V}$ [FS] \\
\hline c' (maciço) & 55,5 & 5,6 & 0,028 & 0,005 & 182,1 & $4,63 \mathrm{E}-3$ \\
\hline$\Phi^{\prime}$ (maciço) & 27,3 & 2,7 & 0,009 & 0,003 & 1,93 & $2,10 \mathrm{E}-5$ \\
\hline$\Phi^{\prime}$ (fundação) & 31,7 & 3,2 & 0,830 & 0,262 & 3,2 & $2,18 \mathrm{E}-1$ \\
\hline \multirow[t]{2}{*}{ NAR } & 218,24 & 2,26 & $-0,075$ & $-0,033$ & 1,7 & $1,87 \mathrm{E}-3$ \\
\hline & & & & \multicolumn{2}{|c|}{ TOTAL $=$ V $[F S]=$} & 0,22 \\
\hline$\beta=\frac{E[F S]-1}{\sigma[F S]}$ & \multicolumn{2}{|c|}{$\frac{2,26-1}{0,22^{2}}=2,67$} & & & & $(4.2)$ \\
\hline
\end{tabular}

Nota-se que nesta seção não houve alteração do índice de confiabilidade mediante a utilização do NAR como variável aleatória. A probabilidade de ruptura continua da ordem de $0,3 \%$. Em ambos casos a variável predominante na variância do FS é o ф’ da fundação conforme indicado na Figura 4.56. 


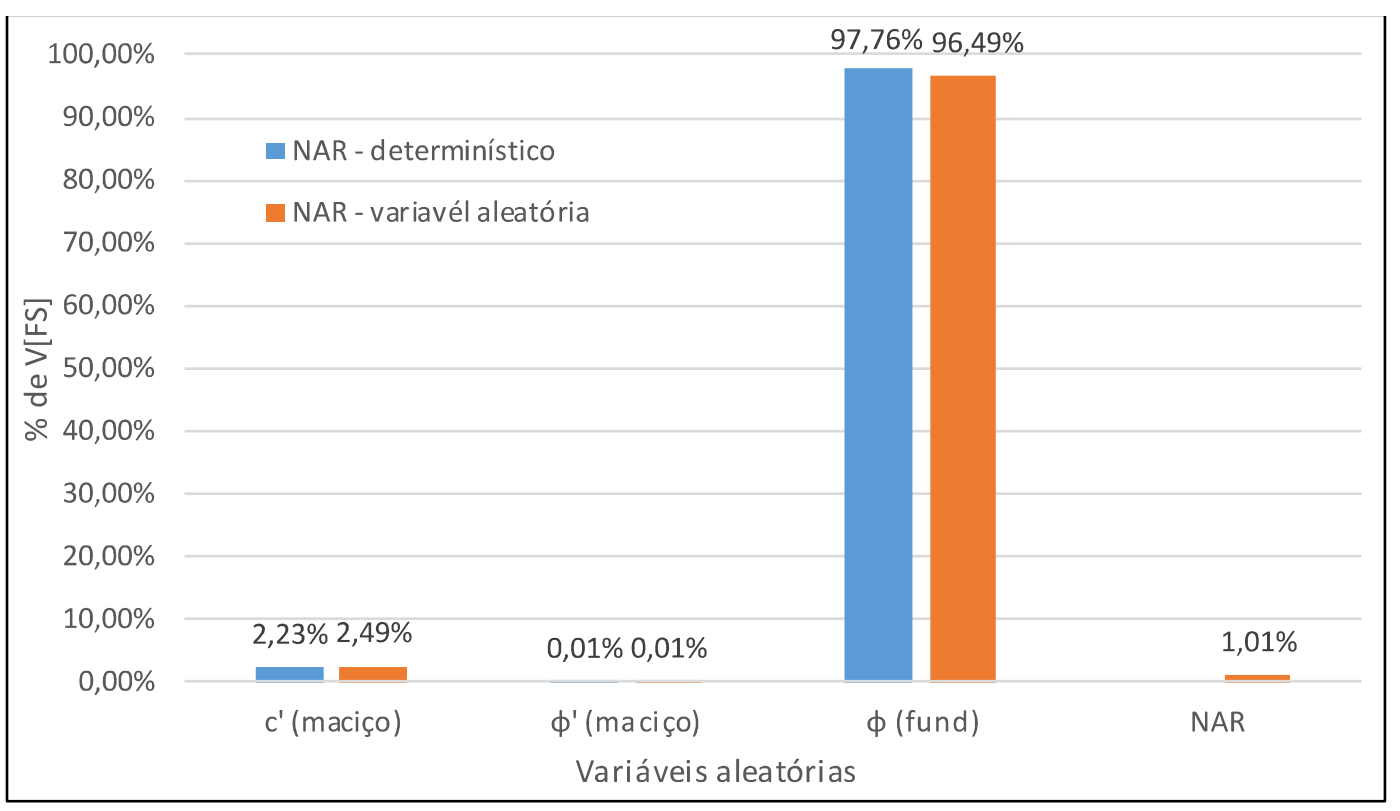

Figura 4.56 - Componentes da variância do FS na seção 129+50

\section{Seção $132+00$}

Os dois tipos de análises anteriores foram repetidos para a seção $132+00$ com as mesmas variáveis. A Tabela 4.18 mostra os cálculos para obtenção da variância do FS a partir do FS determinístico de 2,53 e a Equação 4.3 calcula o índice de confiabilidade do FS.

Tabela 4.18 - Cálculo da variância do FS na seção 132+00 com NAR determinístico

\begin{tabular}{ccccccc} 
& Média (X) & $\Delta \mathrm{X}$ & $\Delta \mathrm{FS}$ & $\frac{\Delta X}{\Delta F S}$ & $\mathrm{~V}[\mathrm{X}]$ & $\mathrm{V}[\mathrm{FS}]$ \\
\cline { 2 - 7 } c' (maciço) $^{\prime}$ & 55,5 & 5,6 & 0,007 & 0,013 & 182,1 & $2,90 \mathrm{E}-2$ \\
$\Phi^{\prime}$ (maciço) & 27,3 & 2,7 & 0,028 & 0,010 & 1,93 & $2,03 \mathrm{E}-4$ \\
$\Phi^{\prime}$ (fundação) & 31,7 & 3,2 & 0,646 & 0,204 & 3,2 & $1,32 \mathrm{E}-1$ \\
\hline & & & & & & \\
$\beta=\frac{E[F S]-1}{\sigma[F S]} \rightarrow$ & $\frac{2,53-1}{0,16^{2}}=3,81$ & & & &
\end{tabular}

Para $\beta=3,81$ temos que $\operatorname{Pr}<0,01 \%$.

A análise que considera o NAR como variável aleatória foi realizada semelhantemente à seção anterior. A Tabela 4.19 apresenta os cálculos para obtenção da variância do FS e em seguida a Equação 4.4 calcula o índice de confiabilidade do FS. 
Tabela 4.19 - Cálculo da variância do FS na seção 132+00 com NAR como variável aleatória

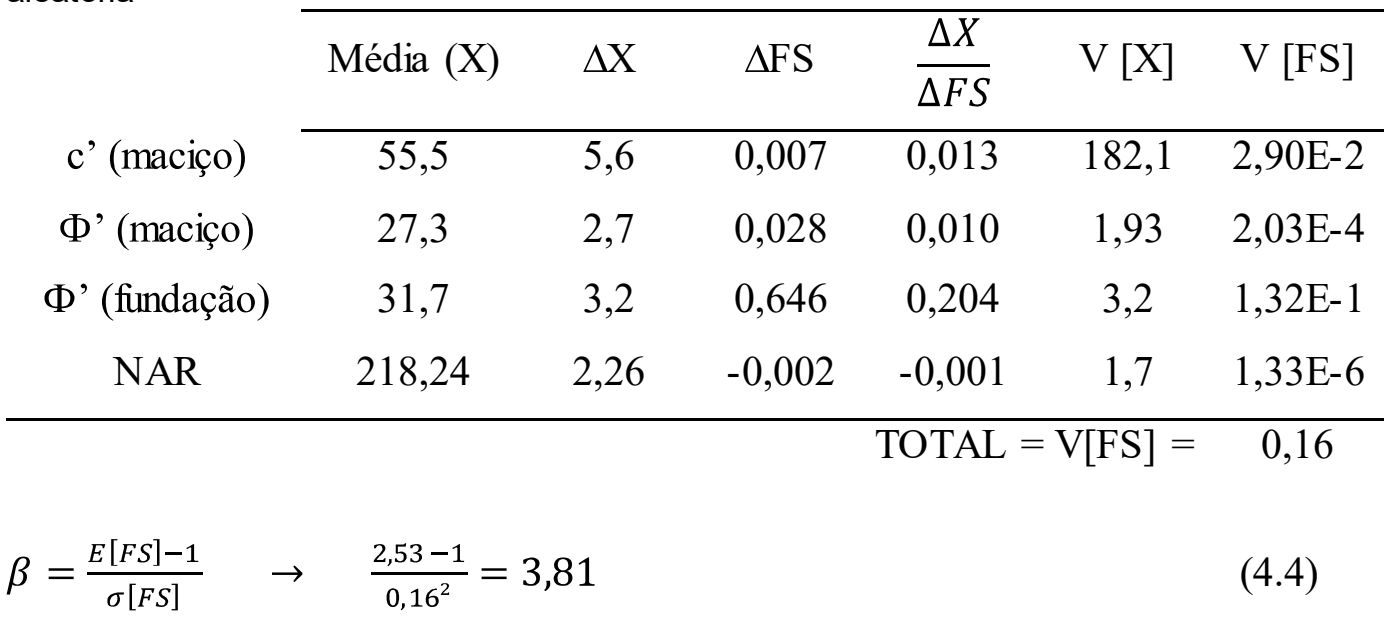

Novamente, a consideração do NAR como variável aleatória não interferiu no índice de confiabilidade do FS. Neste caso a influência do NAR na variância do FS foi nula (Figura 4.57), isso é justificado pelo nível d'água elevado a jusante que minimiza o efeito do NAR no FS do talude de jusante.

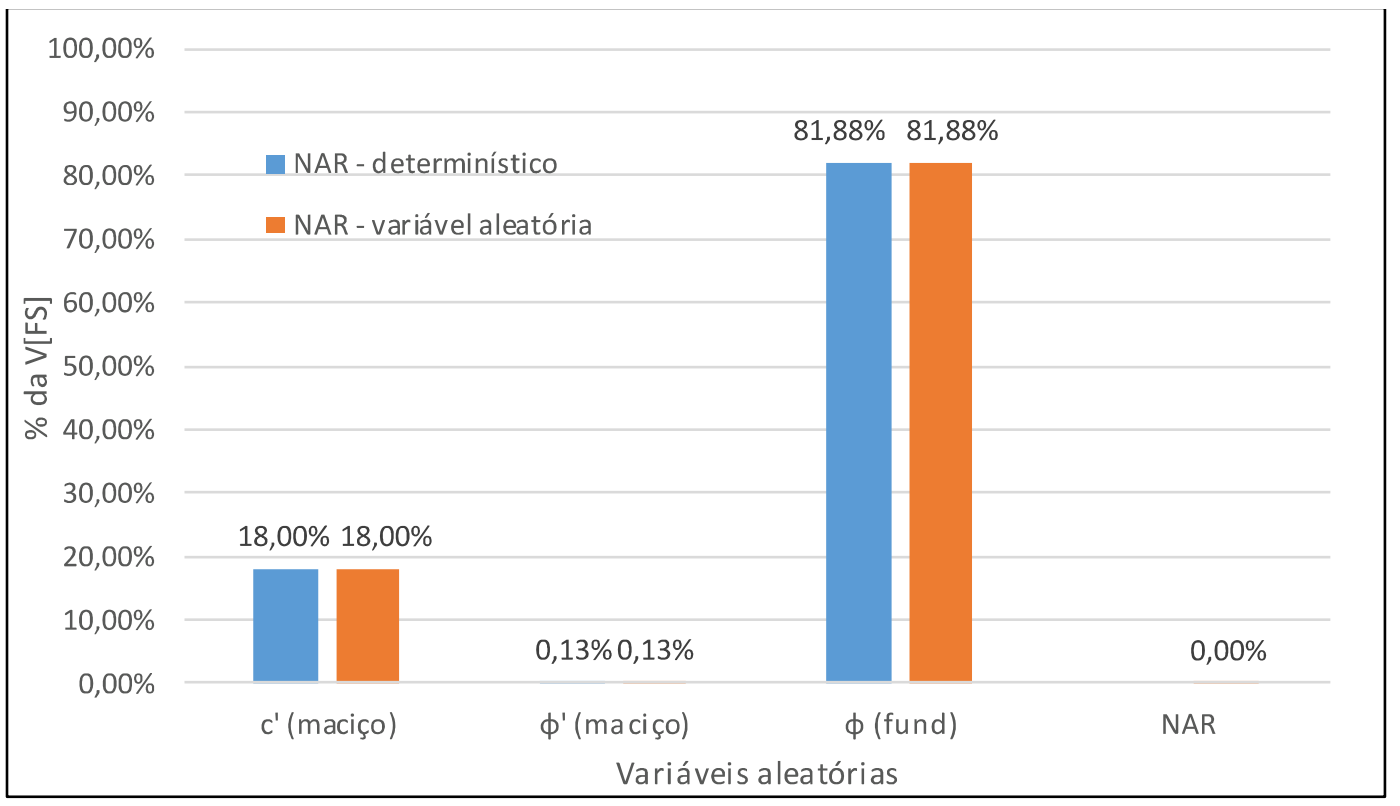

Figura 4.57 - Componentes da variância do FS na seção 132+00

\section{Seção $135+50$}

A Tabela 4.20 mostra os cálculos para obtenção da variância do FS da seção $135+50$ a partir do FS determinístico de 2,07. A Equação 4.5 calcula o índice de confiabilidade do FS. 
Tabela 4.20 - Cálculo da variância do FS na seção 135+50 com NAR determinístico

\begin{tabular}{|c|c|c|c|c|c|c|}
\hline & Média $(\mathrm{X})$ & $\Delta \mathrm{X}$ & $\Delta \mathrm{FS}$ & $\frac{\Delta X}{\Delta F S}$ & $\mathrm{~V}[\mathrm{X}]$ & $\mathrm{V}[\mathrm{FS}]$ \\
\hline c' (maciço) & 55,5 & 5,6 & 0,052 & 0,009 & 182,1 & $1,60 \mathrm{E}-2$ \\
\hline$\Phi^{\prime}$ (maciço) & 27,3 & 2,7 & 0,024 & 0,009 & 1,93 & $1,49 \mathrm{E}-4$ \\
\hline$\Phi^{\prime}$ (fundação) & 31,7 & 3,2 & 0,597 & 0,189 & 3,2 & $1,13 \mathrm{E}-1$ \\
\hline & & & & \multicolumn{2}{|c|}{ TOTAL $=$ V $[F S]=$} & 0,13 \\
\hline$\beta=\frac{E[F S]-1}{\sigma[F S]}$ & \multicolumn{2}{|c|}{$\frac{2,07-1}{0,13^{2}}=2,98$} & & & & $(4.5)$ \\
\hline
\end{tabular}

Para $\beta=2,98$ temos que $\operatorname{Pr}=0,14 \%$.

A Tabela 4.21 mostra os cálculos para obtenção da variância do FS considerando o NAR uma variável aleatória e a Equação 4.6 calcula o índice de confiabilidade.

Tabela 4.21 - Cálculo da variância do FS na seção 135+50 com NAR como variável aleatória

\begin{tabular}{ccccccc}
\cline { 2 - 6 } & Média (X) & $\Delta \mathrm{X}$ & $\Delta \mathrm{FS}$ & $\frac{\Delta X}{\Delta F S}$ & $\mathrm{~V}[\mathrm{X}]$ & $\mathrm{V}[\mathrm{FS}]$ \\
\cline { 2 - 7 } c' (maciço) $^{\prime}$ & 55,5 & 5,6 & 0,052 & 0,009 & 182,1 & $1,60 \mathrm{E}-2$ \\
$\Phi^{\prime}$ (maciço) & 27,3 & 2,7 & 0,024 & 0,009 & 1,93 & $1,49 \mathrm{E}-4$ \\
$\Phi^{\prime}$ (fundação) & 31,7 & 3,2 & 0,597 & 0,189 & 3,2 & $1,13 \mathrm{E}-1$ \\
NAR & 218,24 & 2,26 & $-0,027$ & $-0,012$ & 1,7 & $2,43 \mathrm{E}-4$ \\
\hline & & & & TOTAL $=\mathrm{V}[\mathrm{FS}]=$ & 0,13 \\
$\beta=\frac{E[F S]-1}{\sigma[F S]} \rightarrow$ & $\frac{2,07-1}{0,13^{2}}=2,98$ & & & & \\
\end{tabular}

Nesta seção a consideração do NAR como variável aleatória também não altera o índice de confiabilidade do FS. Na Figura 4.58 nota-se que a importânc ia do NAR para a variância do FS é de $0,19 \%$. 


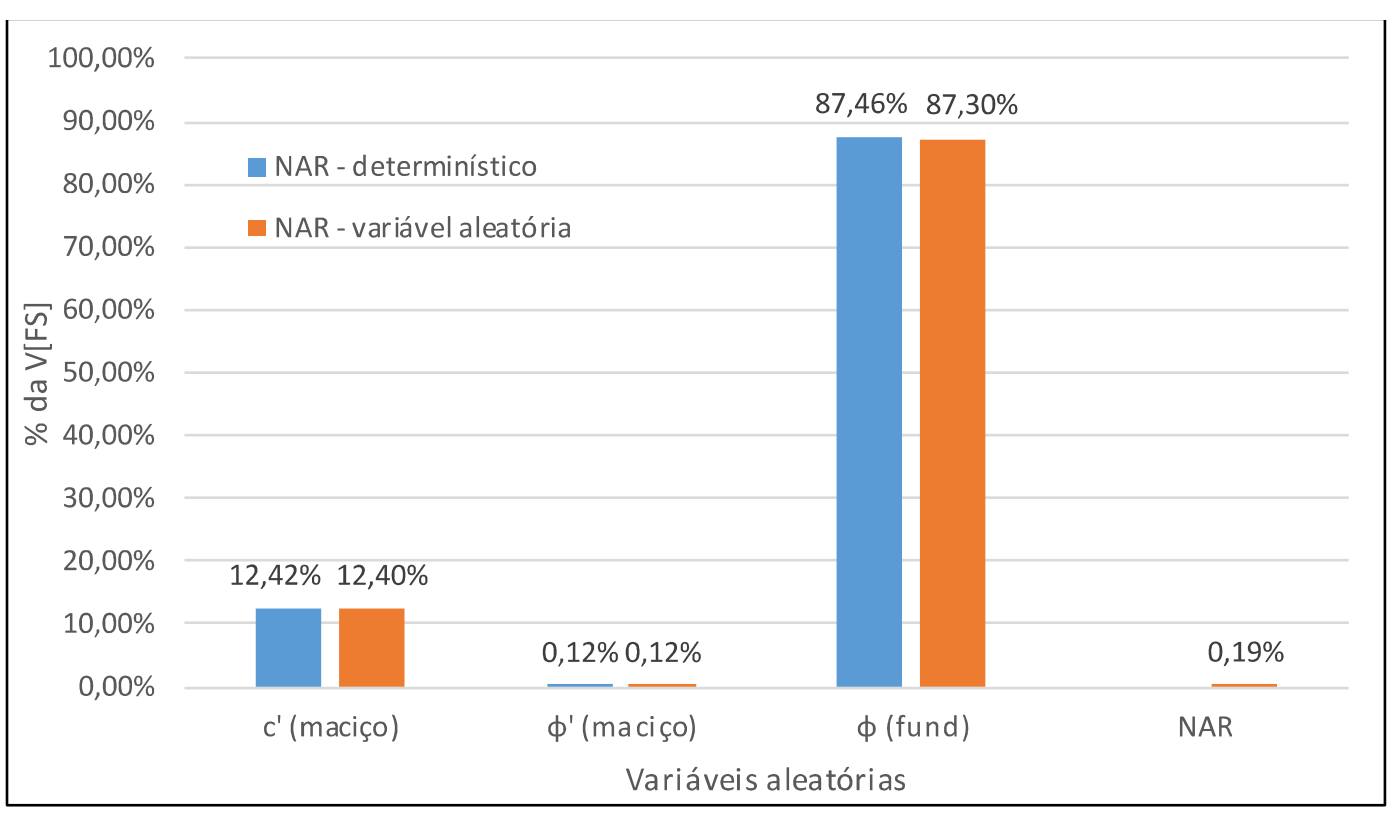

Figura 4.58 - Componentes da variância do FS na seção 135+50

Portanto, a importância do NAR na composição da variância do FS para as três seções citadas confirma o comportamento verificado nas análises determinísticas.

A seção com maior camada de solo na fundação $(129+50)$ apresenta a maior participação do NAR na composição do FS do talude de jusante. Nas análises determinísticas nesta mesma seção o FS possui uma faixa de variação maior que nas demais seções justamente, pela influência do NAR nas poropressões na fundação.

Já na seção 132+00, onde existe nível d'água elevado a jusante, a variação do FS é menor mostrando que o NAR tem menor influência na composição do FS, a Figura 4.57 mostra que nesta análise a influência do NAR na composição da variância FS foi nula.

\section{Seção $138+50$}

A Tabela 4.22 mostra os cálculos para obtenção da variância do FS da seção 138+50 a partir do FS determinístico de 2,66. A Equação 4.7 calcula o índice de confiabilidade do FS. 
Tabela 4.22 - Cálculo da variância do FS na seção 138+50 com NAR determinístico

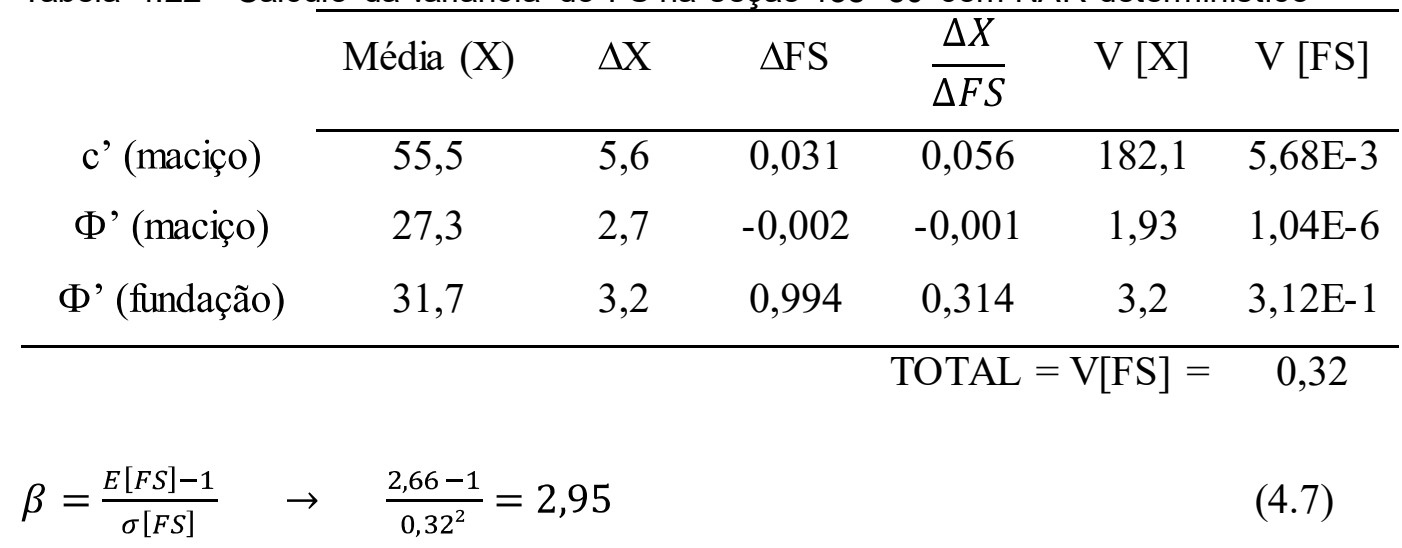

Para $\beta=2,95$ temos que $\operatorname{Pr}=0,15 \%$.

A seguir a Tabela 4.23 mostra os cálculos para obtenção da variância do FS considerando o NAR uma variável aleatória e a Equação 4.8 calcula o índice de confiabilidade.

Tabela 4.23 - Cálculo da variância do FS na seção 138+50 com NAR como variável aleatória

\begin{tabular}{ccccccc} 
& Média (X) & $\Delta \mathrm{X}$ & $\Delta \mathrm{FS}$ & $\frac{\Delta X}{\Delta F S}$ & $\mathrm{~V}[\mathrm{X}]$ & $\mathrm{V}[\mathrm{FS}]$ \\
\cline { 2 - 7 } c' (maciço) & 55,5 & 5,6 & 0,031 & 0,056 & 182,1 & $5,68 \mathrm{E}-3$ \\
$\Phi^{\prime}$ (maciço) & 27,3 & 2,7 & $-0,002$ & $-0,001$ & 1,93 & $1,04 \mathrm{E}-6$ \\
$\Phi^{\prime}$ (fundação) & 31,7 & 3,2 & 0,994 & 0,314 & 3,2 & $3,12 \mathrm{E}-1$ \\
NAR & 218,24 & 2,26 & $-0,052$ & $-0,023$ & 1,7 & $9,01 \mathrm{E}-4$ \\
\hline & & & & TOTAL $=\mathrm{V}[\mathrm{FS}]=$ & 0,32 \\
$\beta=\frac{E[F S]-1}{\sigma[F S]} \rightarrow$ & $\frac{2,66-1}{0,32^{2}}=2,95$
\end{tabular}

Na seção 138+50 também não há alteração do índice de confiabilidade mediante a consideração do NAR como variável aleatória. A Figura 4.59 mostra que a variância do FS ocorre predominantemente devido a variância do ângulo de atrito da fundação. Isso ocorre devido a pequena altura da seção, que condiciona a maior parte da superficie de ruptura na fundação. 


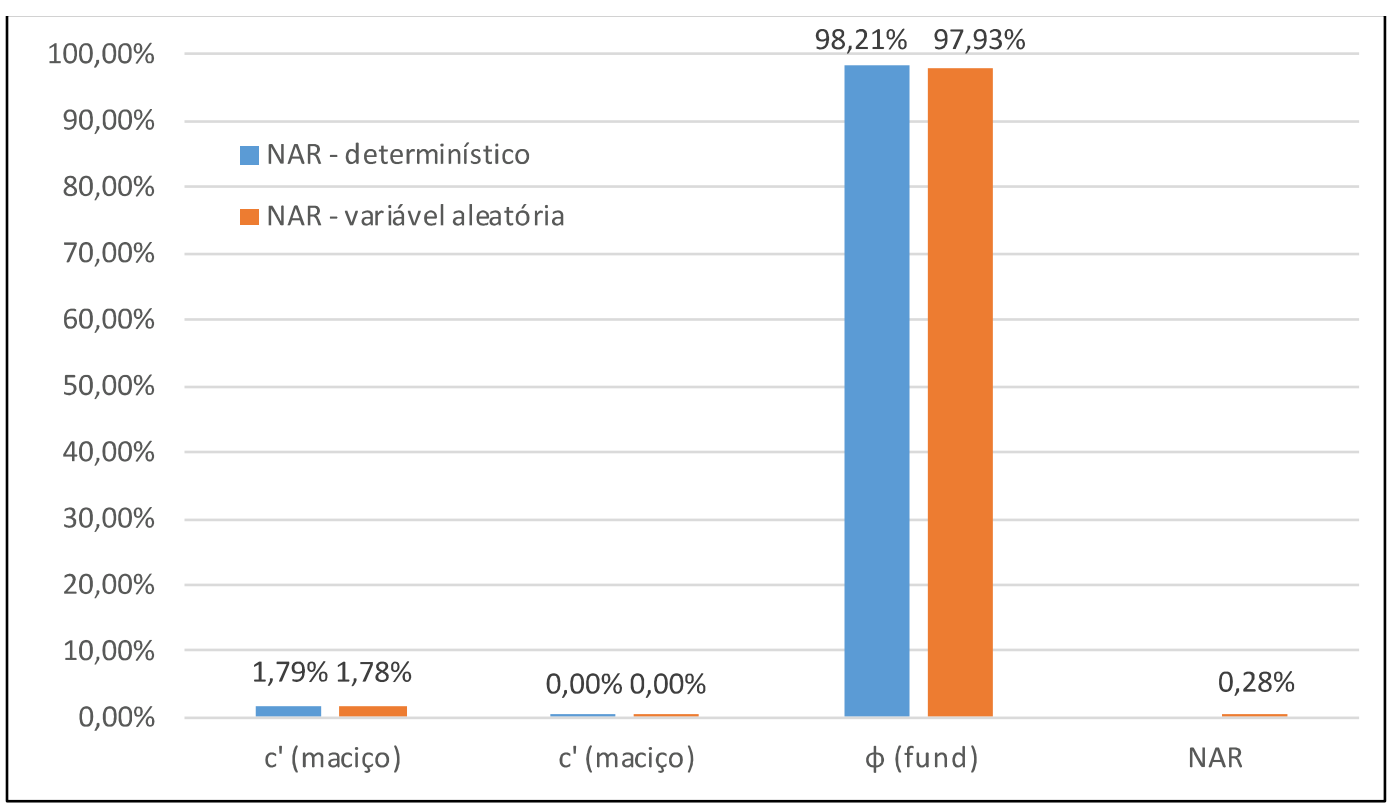

Figura 4.59 - Componentes da variância do FS na seção 138+50

A Tabela 4.24 apresenta um resumo das probabilidades de ruptura para as 4 seções e a importância do NAR neste valor.

Tabela 4.24 - Resumo da probabilidade de ruptura das 4 seções

\begin{tabular}{ccc}
\cline { 2 - 3 } $129+50$ & Pr (\%) & Importância NAR (\%) \\
\cline { 2 - 3 } $132+00$ & 0,3 & 1,01 \\
$135+50$ & $<0,01$ & 0,00 \\
$138+50$ & 0,14 & 0,19 \\
\hline
\end{tabular}

\section{4}

\section{Análise de Recalques}

O objetivo desta análise é simular o comportamento do reservatório no período selecionado e verificar as deformações provocadas no maciço. Para isso são inseridas as características dos materiais, condições de contorno (apoios e peso do reservatório), obtido o estado de tensões in-situ (Figura 4.60) e em seguida a simulação da variação do NAR.

A análise acoplada do SIGMA/W resolve problemas de adensamento do solo considerando equações de deformação e de dissipação de poropressões simultaneamente. Essa análise foi feita independente da análise de fluxo realizada anteriormente (SEEP/W), as condições de contorno hidráulicas foram novamente inseridas diretamente na análise SIGMA/W. As análises de recalques, 
semelhantemente às de fluxo, foram realizadas em 1106 etapas representando um dia por etapa.

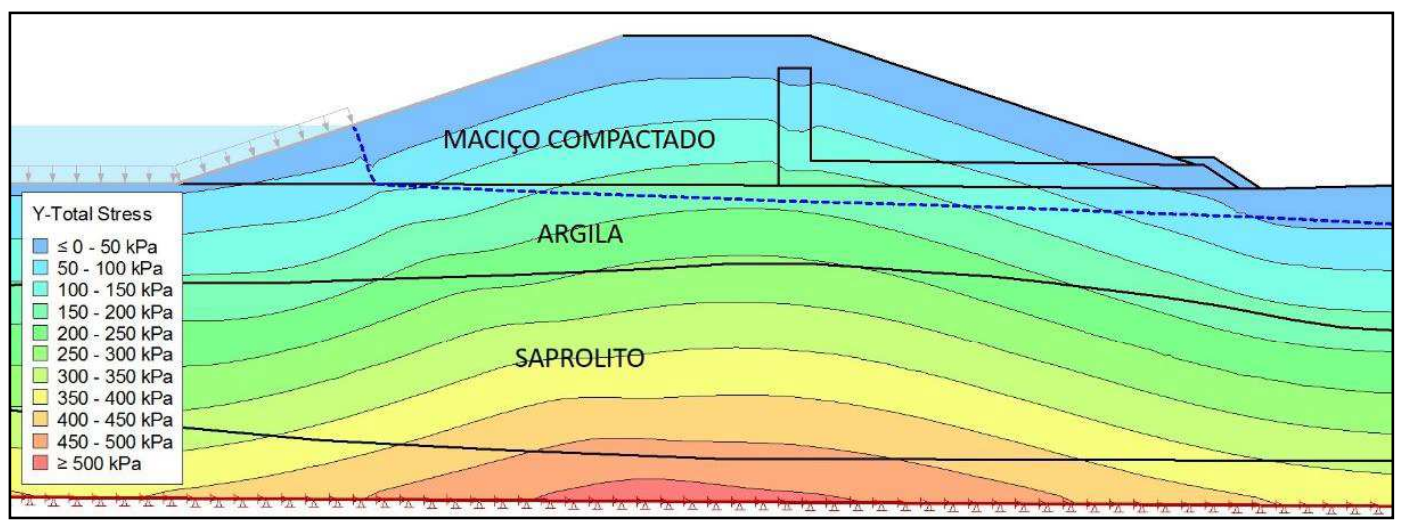

Figura 4.60 - Tensões verticais in-situ na seção 129+50

Nas análises de recalques foi desconsiderada a camada de rip-rap. Neste local foi considerado o mesmo material do maciço compactado. Tal simplificação foi necessária para possibilitar a convergência.

\subsection{1 \\ Condições de Contorno}

As condições de contorno referente ao fluxo foram aplicadas da mesma maneira que na análise SEEP/W, sendo o nível do reservatório como condição de contorno a montante, o medidor de nível d'água a jusante e a saída do tapete drenante como superficie com potencial surgência.

Referente as condições de contorno para análises tensão-deformação, foram inseridos apoios fixos em $\mathrm{X}$ e em $\mathrm{Y}$ na base da fundação, impedindo qualquer tipo de deslocamento, apoio móvel na direção Y nos limites laterais da modelagem, permitindo recalque e impedindo o deslocamento lateral, e uma pressão a montante da barragem representando o peso do reservatório. Assim como na análise de fluxo, o peso do reservatório é variado diariamente.

\subsection{2 \\ Parâmetros de Deformabilidade}

Os estudos de deformabilidade foram realizados considerando o solo com comportamento linear-elástico. Analisando as curvas de adensamento (Anexo II) nota-se que as tensões de sobreadensamento tanto do maciço compactado como da 
fundação, são superiores às tensões predominantes in-situ (Figura 4.60), reforçando o comportamento predominantemente elástico do solo.

Considerando este tipo de comportamento do solo, para análise de recalques no SIGMA/W são necessários os parâmetros de deformabilidade E e v juntamente com a compressibilidade do solo. Esses parâmetros foram extraídos dos resultados dos ensaios triaxiais drenados, com variação de volume.

Foram analisados 15 ensaios realizados com amostras indeformadas do maciço compactado e das curvas de tensão $\mathrm{x}$ deformação foi extraído o valor de $\mathrm{E}_{50}$ para as tensões de confinamento de 100,300 e $600 \mathrm{kPa}$, sendo que os valores obtidos com tensão de confinamento de $600 \mathrm{kPa}$ não foram levados em consideração na análise, visto que no trecho em estudo o maciço compactado não é submetido a esse nível de tensões.

$\mathrm{O}$ módulo de elasticidade da fundação $\mathrm{E}_{50}$ foi obtido analisando as curvas tensão $\mathrm{x}$ deformação de 12 ensaios triaxiais do tipo $\mathrm{CD}$, realizados com amostras indeformadas da fundação. Os ensaios foram adensados para 100, 300 e $600 \mathrm{kPa}$.

A Figura 4.61 mostra o histograma dos valores de E$_{50}$ obtidos das amostras do maciço compactado, enquanto a Figura 4.62 mostra o histograma dos valores de E50 obtidos das amostras da fundação.

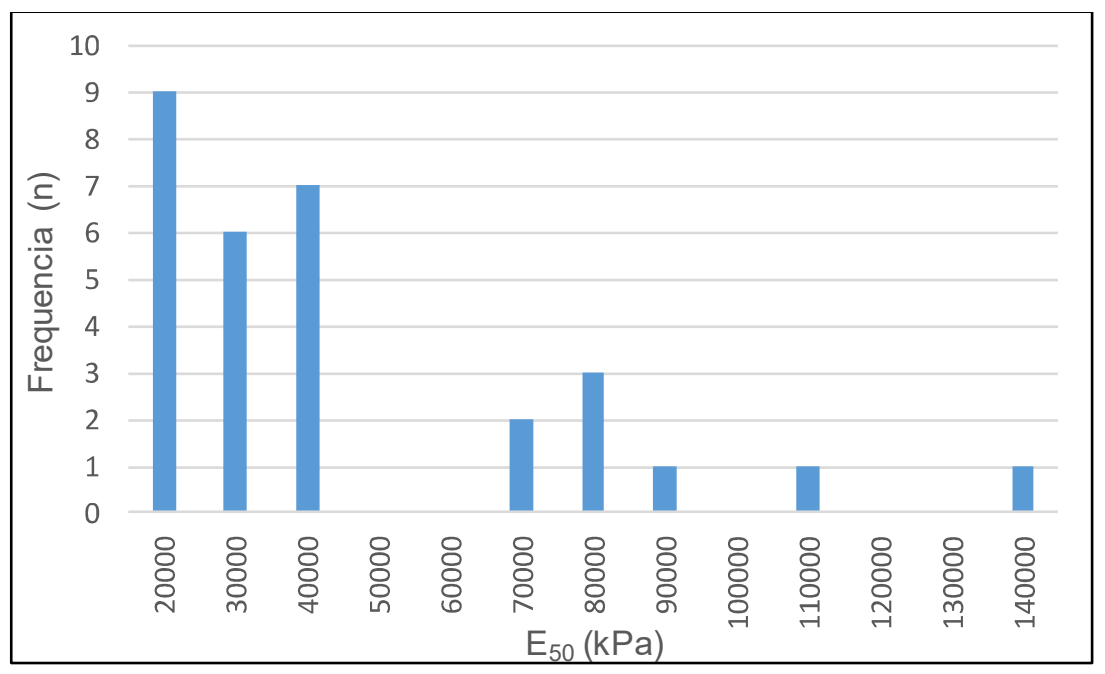

Figura 4.61 - Histograma do E50 do maciço compactado

Observando o histograma, nota-se que a maior parte dos ensaios do maciço compactado resultaram no módulo E50 na faixa de 20 a $40 \mathrm{MPa}$, sendo adotado o valor $\mathrm{E}_{50}=30 \mathrm{MPa}$ para comparar os recalques simulados com os medidos. 


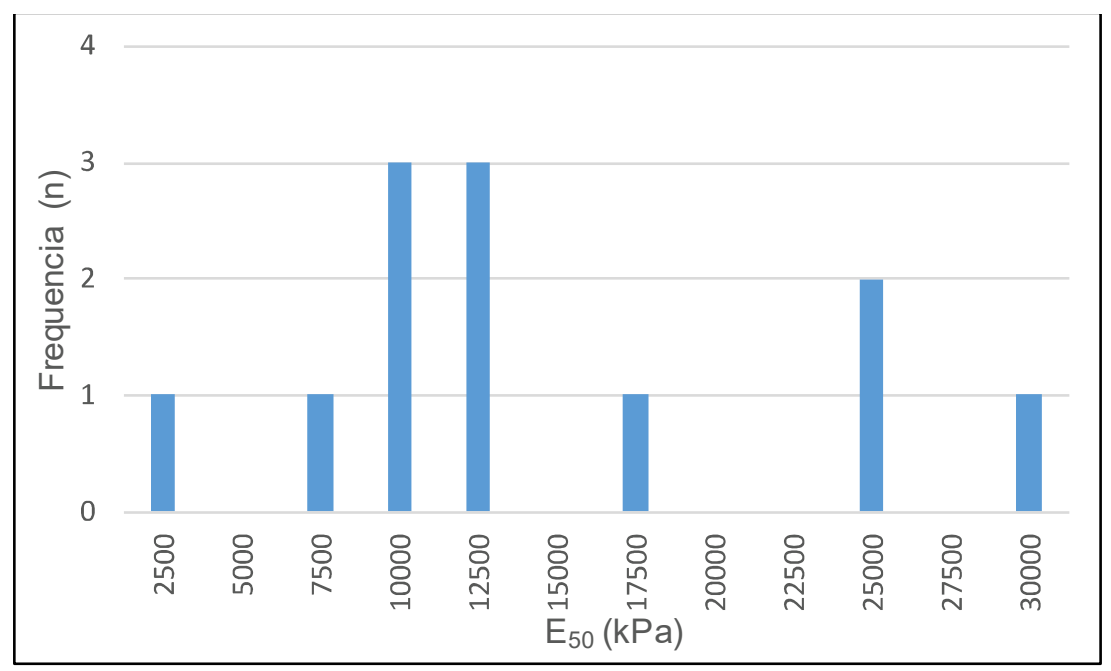

Figura 4.62 - Histograma do E50 da fundação

Procedimento semelhante foi utilizado para a fundação, onde o módulo de elasticidade do saprolito fica na faixa entre 10 a 12,5 MPa. Os dois ensaios que resultaram no $\mathrm{E}_{50}=22,5 \mathrm{MPa}$ foram adensados para tensão de $100 \mathrm{kPa}$, que representa a tensão na camada superficial do solo. Portanto a argila de fundação foi considerada com $\mathrm{E}_{50}=22,5 \mathrm{MPa}$. Para o saprolito, camada mais profunda, foi adotado $12,5 \mathrm{MPa}$.

Assim como o módulo de Young (E), o coeficiente de Poisson (v) foi obtido por meio dos resultados ensaios triaxiais drenados, considerando o deslocamento vertical e a variação de volume. A Figura 4.63 mostra o histograma dos valores de $v$ obtidos das amostras do maciço compactado enquanto a Figura 4.64 mostra o histograma dos valores de $v$ obtidos das amostras da fundação.

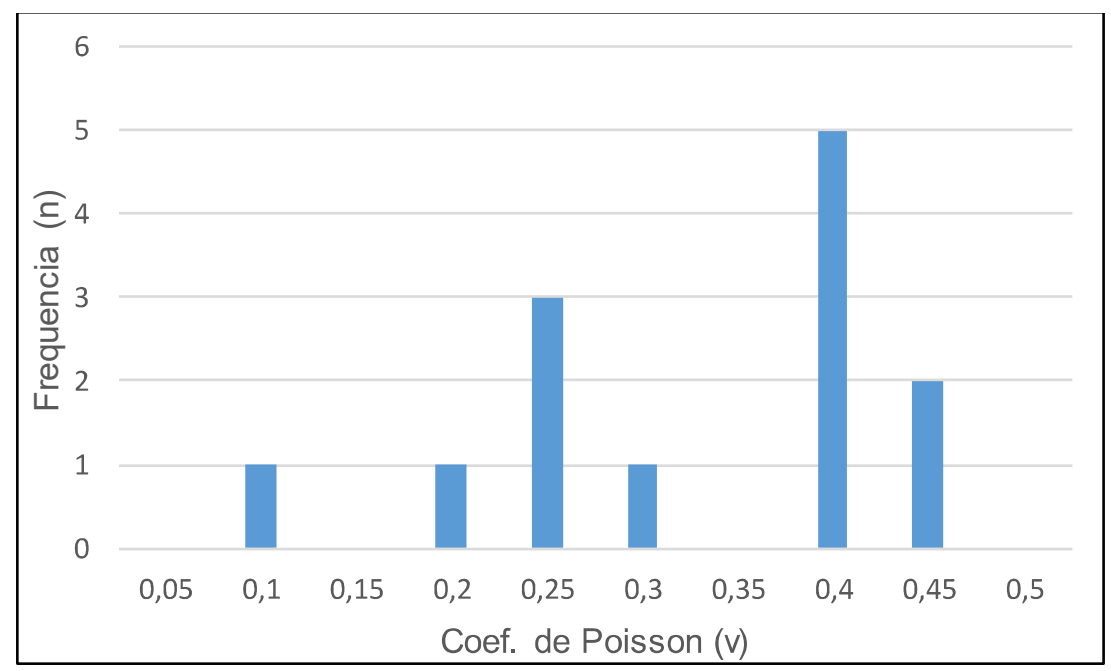

Figura 4.63 - Histograma do coeficiente de Poisson para o maciço compactado 


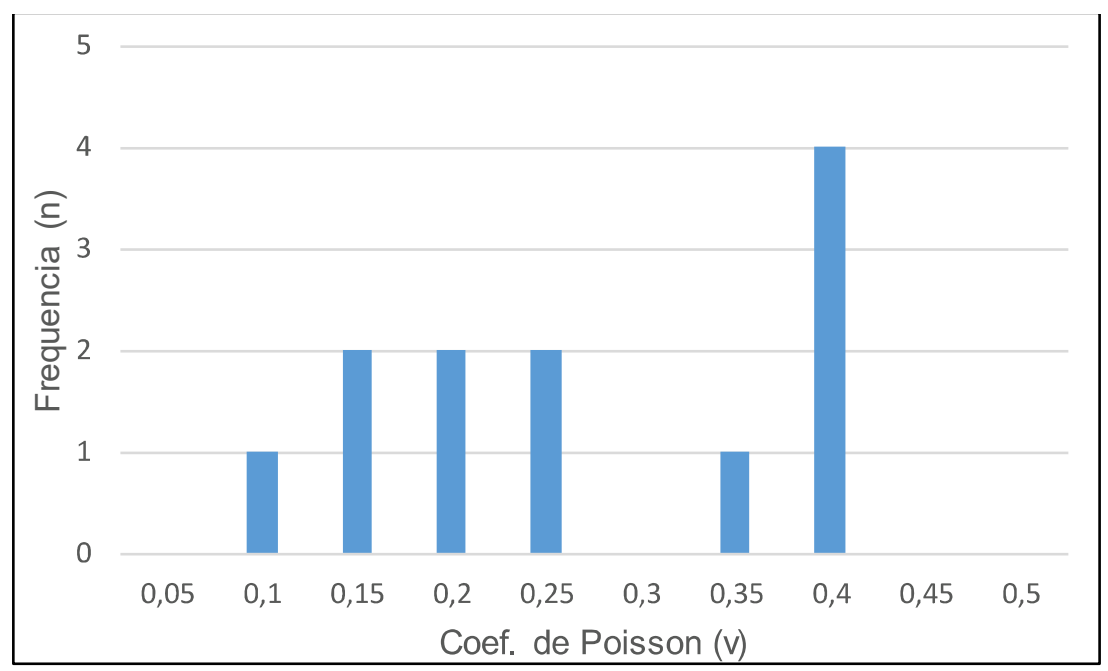

Figura 4.64 - Histograma do coeficiente de Poisson para a fundação

Tanto para o solo do maciço compactado como da fundação o valor de 0,4 foi o mais representativo para o coeficiente de Poisson, sendo assim, foi adotado esse valor para as análises.

O parâmetro de compressibilidade utilizado foi o coeficiente de variação volumétrica $\left(\mathrm{m}_{\mathrm{V}}\right)$, que pode ser obtido a partir do módulo de compressibilidade confinada (M), conforme Equação 4.9. O módulo de compressão confinada, por sua vez, foi obtido pela sua relação com E e v considerando a lei de Hooke generalizada, mostrada na Equação 4.10.

$$
\begin{aligned}
& m_{v}=\frac{1}{M} \\
& M=\frac{E(1-v)}{(1+v)(1-2 v)}
\end{aligned}
$$

Os valores de $\mathrm{E}, v$ e $\mathrm{m}_{\mathrm{v}}$ não são lineares e dependem do nível de tensões, tais valores não correspondem às características do solo existentes in-situ, mas buscam representar um modelo aproximado. A Tabela 4.25 mostra os coeficientes de variação volumétrica obtidos.

Tabela 4.25 - Coeficientes de variação volumétrica do solo

\begin{tabular}{cc}
\hline Material & $\mathrm{m}_{\mathrm{v}}(1 / \mathrm{kPa})$ \\
\hline Argila compactada & $1,55 \times 10^{-5}$ \\
Argila da fundação & $2,07 \times 10^{-5}$ \\
Saprolito da fundação & $3,73 \times 10^{-5}$ \\
\hline
\end{tabular}


A velocidade de recalque não é calculada pelo coeficiente de adensamento obtido pelo ensaio oedométrico convencional, pois o programa utiliza a teoria de adensamento proposta por Biot (1941), que considera adensamento em duas dimensões. Por esse motivo utiliza-se o coeficiente de variação volumétrica $\left(\mathrm{m}_{\mathrm{v}}\right)$ como parâmetro de compressibilidade.

\subsection{3}

\section{Análise do Período Proposto}

Para análise de recalques foram realizadas simulações exclusivas de tensão versus deformação para obter a deformação plástica da barragem e simulações acopladas com adensamento. O objetivo foi observar os deslocamentos verticais ocorridos num ponto da crista da barragem, mais especificamente próximo ao topo do talude de jusante, local onde estão instalados os marcos de referência nos quais são realizadas as leituras altimétricas.

As Figuras 4.65, 4.66, 4.67 e 4.68 mostram os deslocamentos verticais obtidos para os dois tipos de análises.

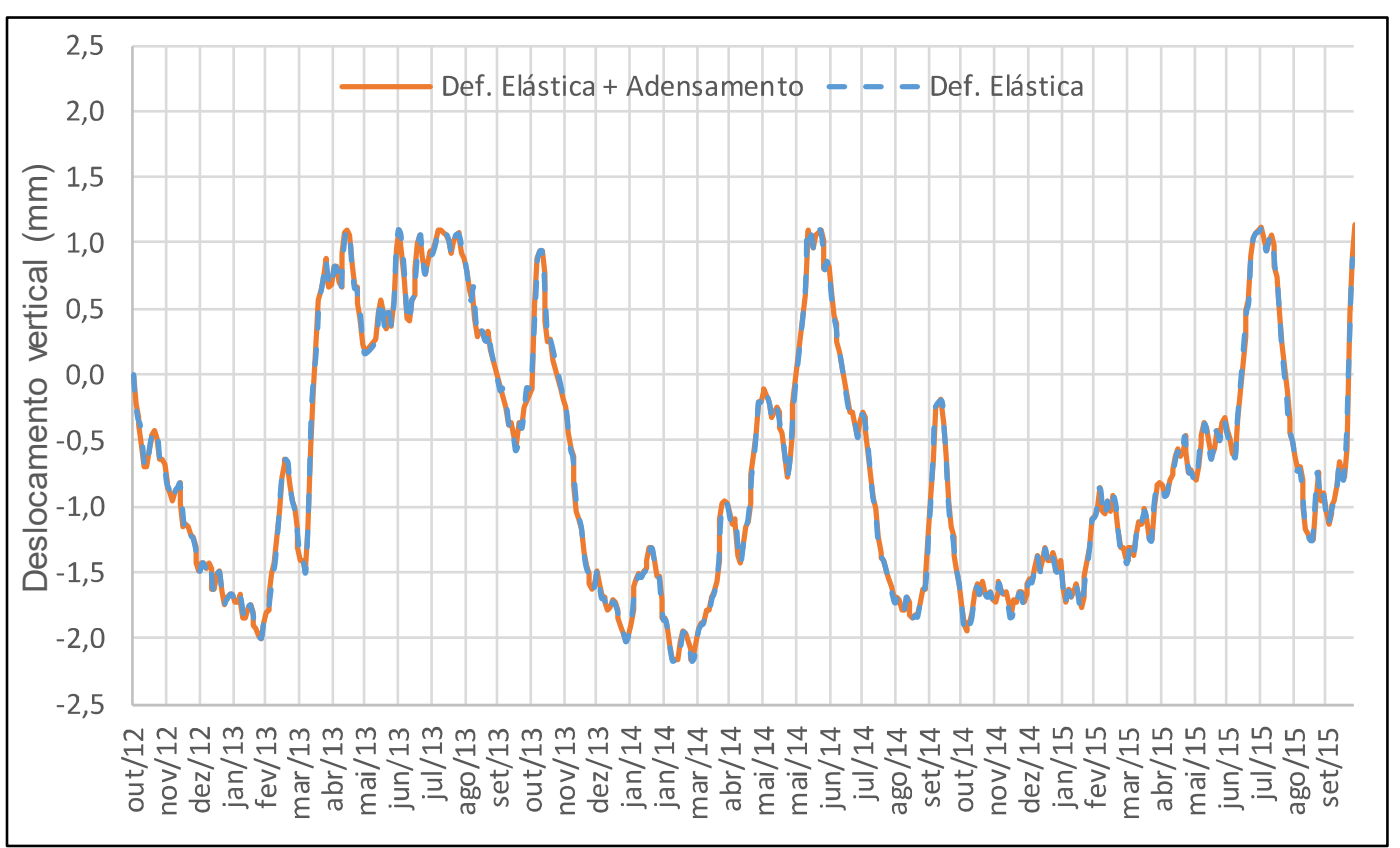

Figura 4.65 - Deslocamento vertical na crista da seção 129+50 


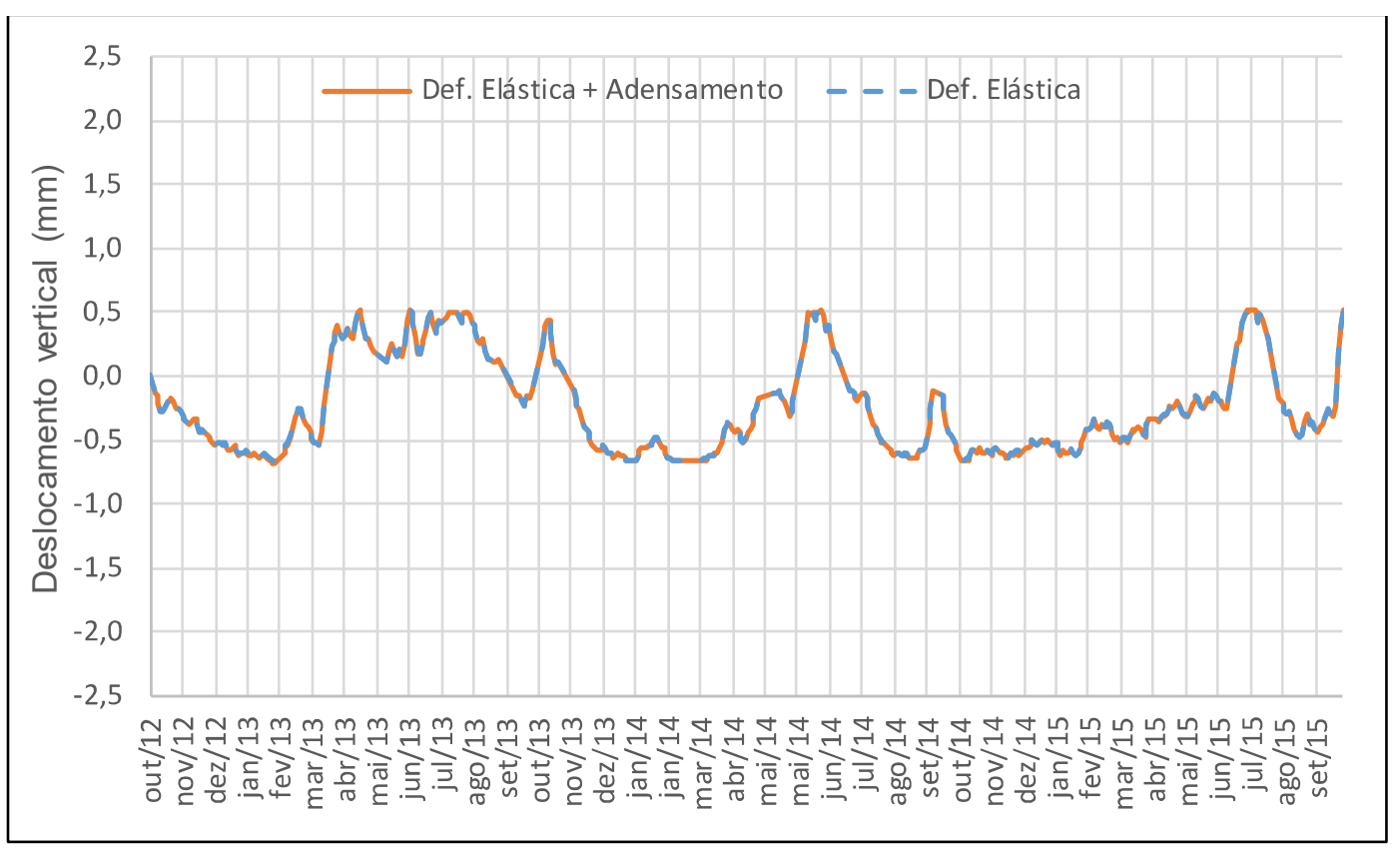

Figura 4.66 - Deslocamento vertical na crista da seção 132+00

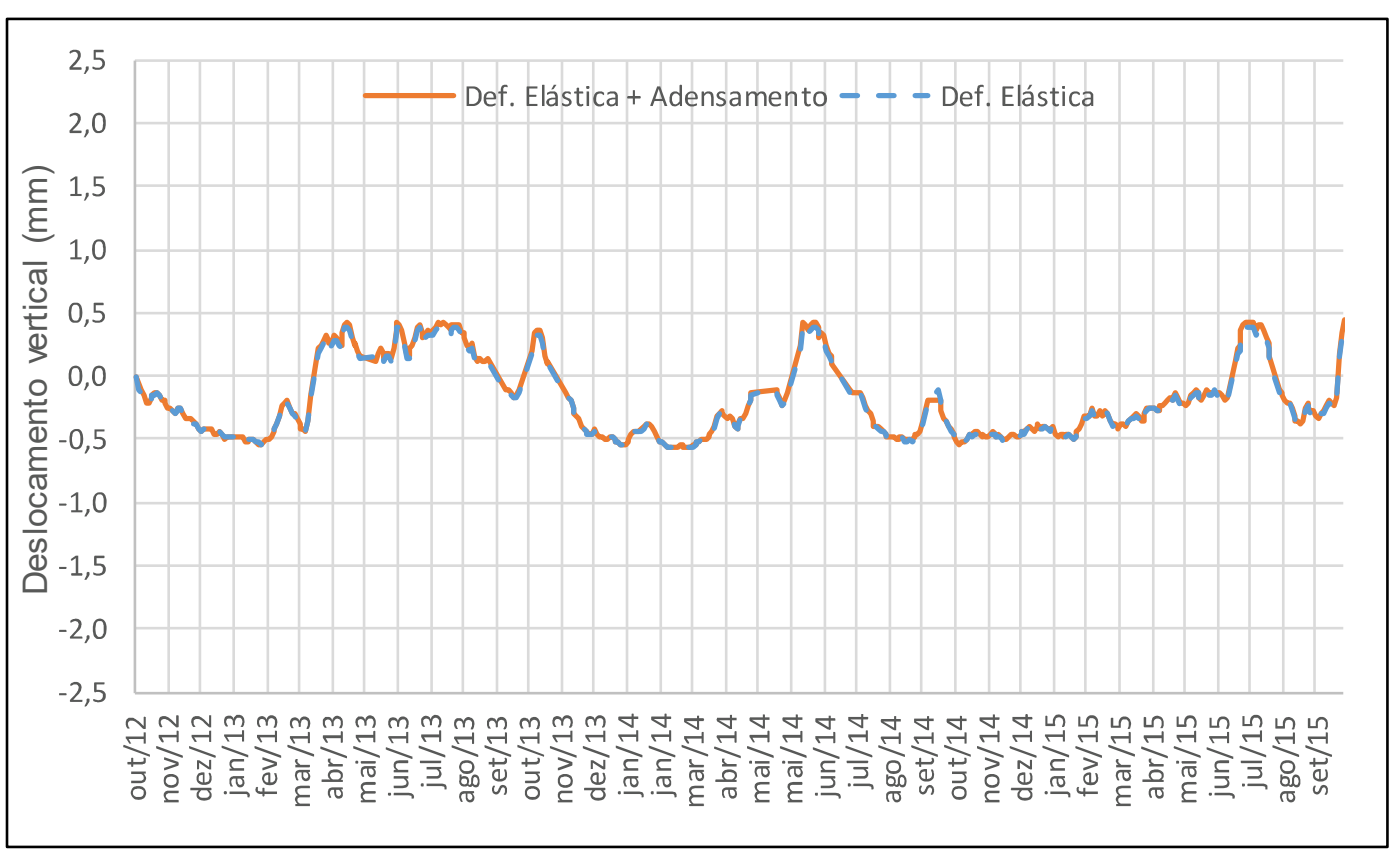

Figura 4.67 - Deslocamento vertical na seção 135+50 


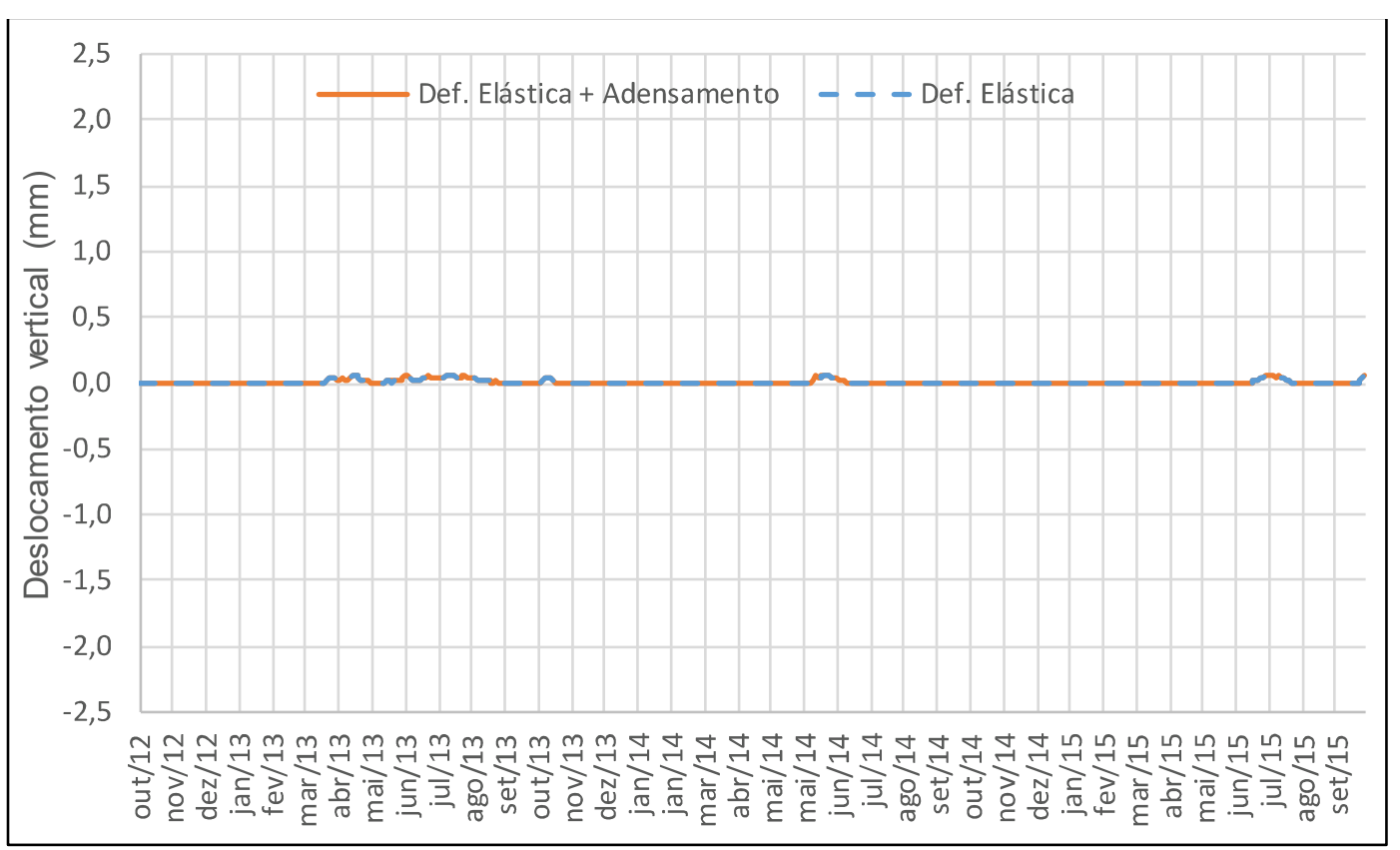

Figura 4.68 - Deslocamento vertical na crista da seção $138+50$

Analisando os gráficos de deslocamentos verticais na crista da barragem verifica-se que a simulação que considera o adensamento apresentou resultado semelhante à simulação que considera somente o comportamento elástico, com deslocamentos milimétricos e em função do nível do reservatório. Isso mostra que apesar de existir um ciclo de descarregamento e carregamento diferenciado na estrutura, essa variação de tensões não provoca adensamento primário, aquele que ocorre com a variação de tensões efetivas.

Os deslocamentos para cada seção possuem ordem de grandeza diferente devido a espessura da camada de solo da fundação. A seção 129+50 é a que possui maior camada de solo na fundação e, portanto, a que possui maiores deslocamentos. A seção $138+50$ é a menor das estudadas e fica seca na maior parte do tempo, por isso não apresenta deslocamentos devido à variação do NAR.

Na prática o deslocamento apontado pela simulação é considerado nulo, pois a faixa de variação é muito pequena, da ordem de $3 \mathrm{~mm}$. Já o deslocamento verificado pela instrumentação em campo é da ordem de $3 \mathrm{~cm}$ e segue uma tendência de recalque, característica de adensamento.

As simulações mostraram que não ocorreu adensamento primário devido à variação do NAR, porém, existem outros fatores não constantes nas simulações que podem provocar variação de tensões e consequente adensamento primário, como por exemplo, sobrecarga de veículos pesados ou equipamentos, intemperismo e 
alteração das características físicas e/ou químicas do solo, entre outros. É possível, também, que tenha ocorrido adensamento secundário, aquele que ocorre devido a alteração viscosa do solo.

Como os deslocamentos verticais são medidos apenas na crista da barragem, não é possível distinguir se o recalque ocorre no maciço compactado, nas camadas de solo de fundação ou em ambos materiais. Vale ressaltar que o medidor que apresenta maior tendência de recalque está localizado próximo à estaca $135+50$, que possui a menor camada de fundação.

No fim desta etapa foi possível concluir que não ocorreu adensamento primário devido à variação de tensões do reservatório. Não se chegou a uma conclusão sobre o real motivo do recalque.

No entanto, os recalques medidos estão relacionados ao período em que houve deplecionamento do reservatório, e após o retorno à cota normal ( 220 m) os recalques estabilizaram. 


\section{5 \\ Estudos de Casos}

As análises do capítulo anterior, referente a um período específico, mostram de maneira geral o comportamento da barragem ao longo de três anos. Neste capítulo será mostrado com mais detalhes o comportamento da barragem sob fluxo permanente e mediante rebaixamento rápido. Será mostrado também o comportamento da barragem sob uma possível obstrução do sistema de drenagem.

\section{1}

\section{Fluxo Permanente}

Existem análises de estabilidade da época de projeto que consideravam fluxo permanente para o NAR em diversas cotas. No entanto, tais análises eram para algumas seções típicas e com parâmetros obtidos das amostras da área de empréstimo. Com diferentes seções modeladas e com parâmetros obtidos das amostras do maciço compactado, foram realizadas novas análises de estabilidade determinísticas e probabilísticas considerando o NAR em várias cotas.

Como foram simuladas condições hipotéticas, por exemplo, com NAR acima da cota 220,50 m que é o máximo praticado, não foi possível usar dados dos medidores de nível d'água a jusante, pois não se sabe como o nível freático se comportaria para tais situações. Foi então adotada uma condição conservadora que em todas as situações, independente do NAR, o nível freático a jusante coincide com o nível do terreno.

Não foram realizadas as análises para a seção $132+00$ pois, como visto no capítulo anterior, o nível freático tem influência do nível d'água a jusante da barragem. A solução adotada no capítulo anterior de usar os dados do piezômetro como condição de contorno não foi utilizada neste caso, pois não se sabe como o instrumento se comportaria mediante o NAR em cotas mais altas.

Para análise de estabilidade foram utilizados os parâmetros obtidos pelo ensaio consolidado e drenado (CD). As Figuras 5.1, 5.2 e 5.3 mostram os fatores de 
segurança para os taludes de montante e jusante em condições de fluxo permanente para cada metro de variação do NAR.

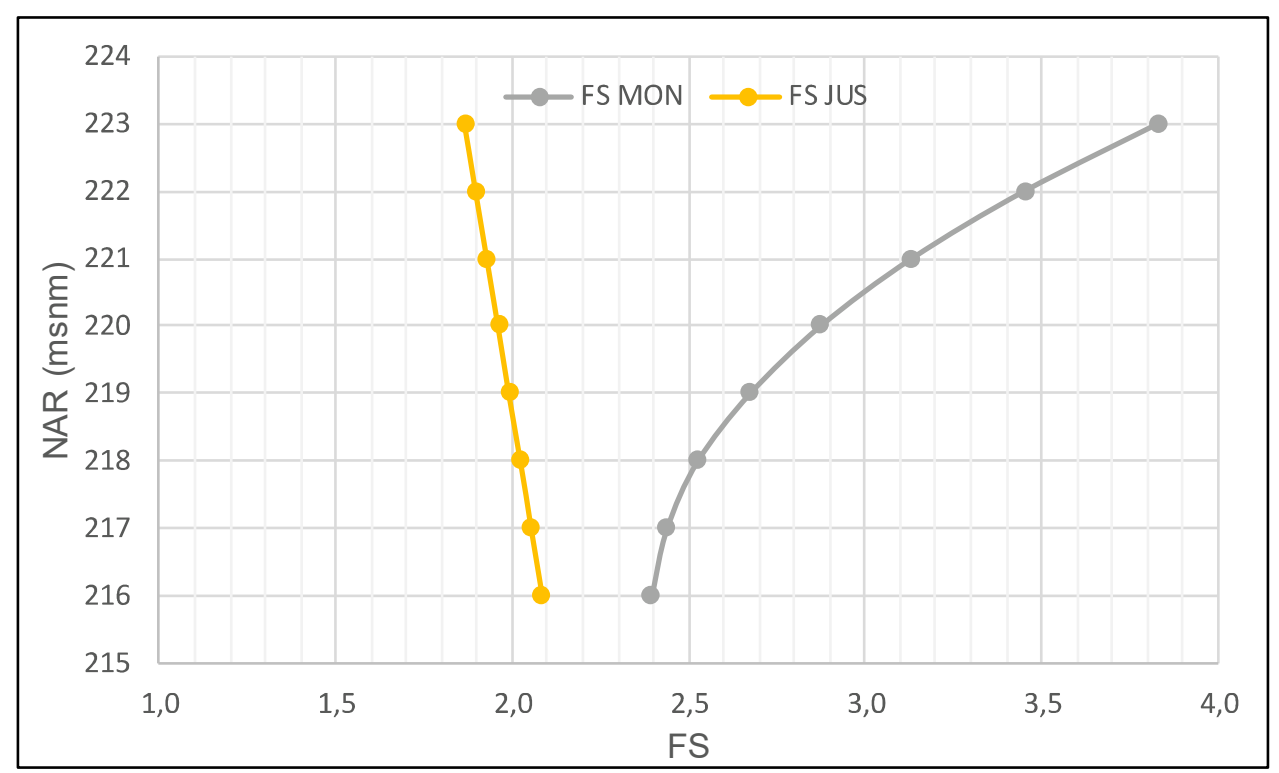

Figura 5.1 - Fatores de segurança para seção 129+50

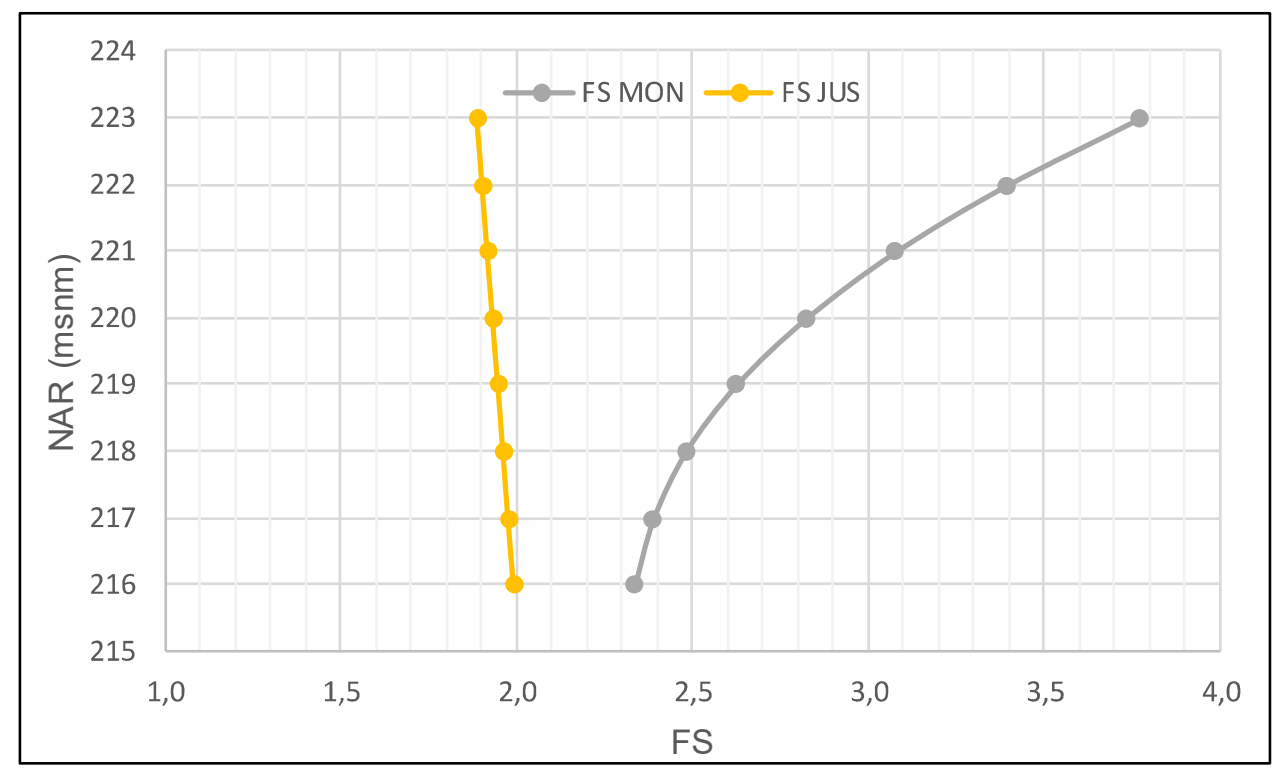

Figura 5.2 - Fatores de segurança para seção 135+50 


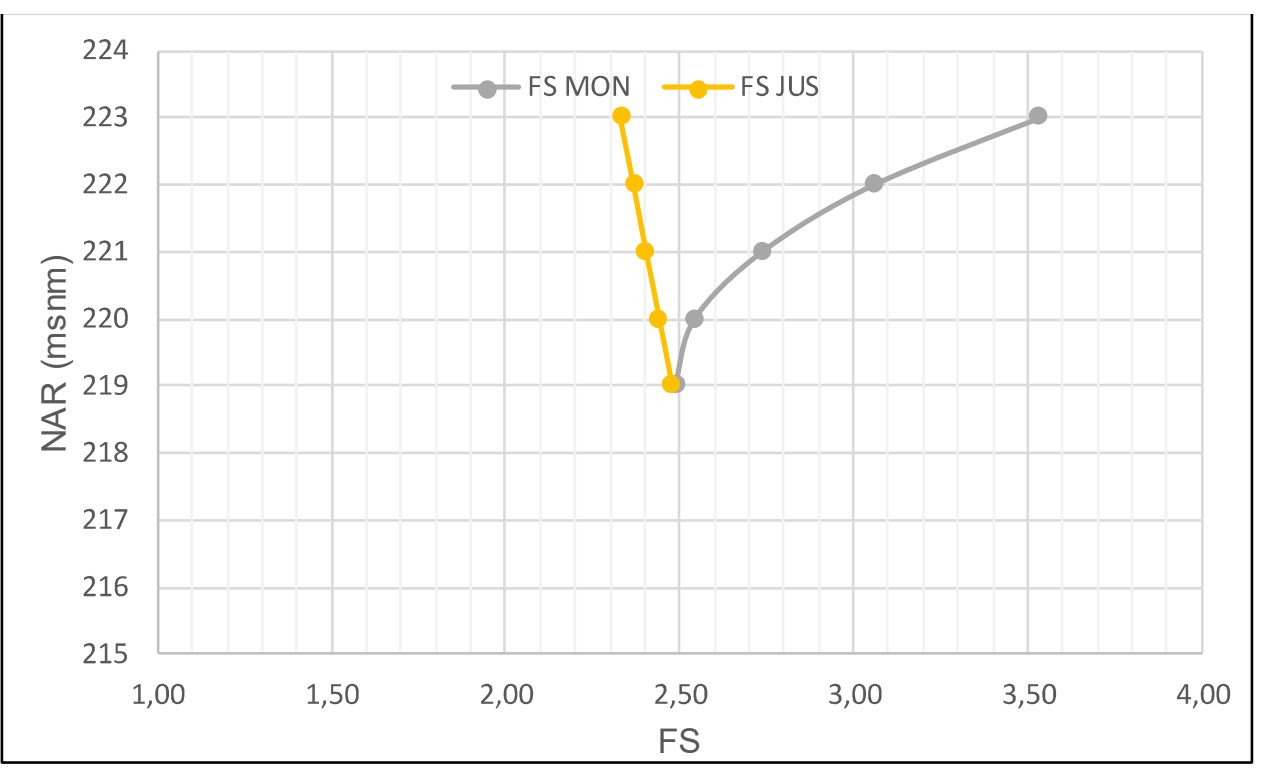

Figura 5.3 - Fatores de segurança para seção 138+50

As três simulações mostram que o FS do talude de montante possui uma faixa de variação consideravelmente maior que o FS do talude de jusante. A curva do FS de montante possui o mesmo formato nas três seções, mostrando que a contribuição do reservatório para estabilidade do talude é semelhante em todas as seções.

O FS do talude de jusante varia em menor proporção e em função das poropressões na fundação. Nota-se que na seção $135+50$, o FS varia menos que na seção $129+50$. Isso ocorre porque a camada de solo na fundação é menor e, consequentemente, a variação é menor.

Para visualizar essa relação da poropressão na fundação com o FS do talude de jusante, as Tabelas 5.1, 5.2 e 5.3 mostram a variação do NAR, da carga nos piezômetros abaixo do maciço compactado e do FS.

Tabela 5.1 - Relação entre NAR, poropressões e FS na seção 129+50

\begin{tabular}{ccc}
\hline$\Delta \mathrm{NAR}(\mathrm{msnm})$ & $\Delta \mathrm{H}(\mathrm{m})$ & $\Delta \mathrm{FS}$ \\
\hline $216-217$ & 0,40 & $-0,04$ \\
$217-218$ & 0,39 & $-0,03$ \\
$218-219$ & 0,39 & $-0,04$ \\
$219-220$ & 0,39 & $-0,04$ \\
$220-221$ & 0,39 & $-0,04$ \\
$221-222$ & 0,39 & $-0,04$ \\
$222-223$ & 0,39 & $-0,04$
\end{tabular}


Tabela 5.2 - Relação entre NAR, poropressões e FS na seção 135+50

\begin{tabular}{ccc}
\hline$\Delta \mathrm{NAR}(\mathrm{msnm})$ & $\Delta \mathrm{H}(\mathrm{m})$ & $\Delta \mathrm{FS}$ \\
\hline $216-217$ & 0,24 & $-0,015$ \\
$217-218$ & 0,23 & $-0,014$ \\
$218-219$ & 0,24 & $-0,015$ \\
$219-220$ & 0,23 & $-0,015$ \\
$220-221$ & 0,24 & $-0,015$ \\
$221-222$ & 0,23 & $-0,014$ \\
$222-223$ & 0,23 & $-0,015$
\end{tabular}

Tabela 5.3 - Relação entre NAR, poropressões e FS na seção 138+50

\begin{tabular}{ccc}
\hline$\Delta$ NAR $(\mathrm{msnm})$ & $\Delta \mathrm{H}(\mathrm{m})$ & $\Delta \mathrm{FS}$ \\
\hline $219-220$ & 0,28 & $-0,04$ \\
$220-221$ & 0,28 & $-0,04$ \\
$221-222$ & 0,28 & $-0,04$ \\
$222-223$ & 0,28 & $-0,04$ \\
\hline
\end{tabular}

Os valores das tabelas permitem avaliar a sensibilidade do FS do talude de jusante com a elevação do NAR e consequente resposta das poropressões em seções com diferentes camadas de fundação.

\section{2 \\ Rebaixamento Rápido}

A estabilidade do talude de montante da barragem é um fator que merece atenção sob condição de rebaixamento rápido do NAR. Segundo Singh \& Varshney (1995) apud Almeida (2013) o maior momento de instabilidade pode estar associado a um rebaixamento total ou até mesmo parcial, pois o fato do pé do maciço estar submerso reduz a sua resistência e juntamente com o peso do maciço saturado causa a instabilidade da estrutura. Por esse motivo foram simulados rebaixamentos totais e parciais.

Nas análises foram usados os parâmetros de resistência não drenada, obtidos pelos ensaios CD. Assim como nas análises anteriores, para fins de permeabilidade o maciço compactado e o sistema de drenagem foram considerados parcialmente saturados, enquanto o solo da fundação foi considerado totalmente saturado. Em 
relação ao critério de resistência foi considerado que o conjunto se encontra todo saturado.

A seguir são mostrados quatro casos de rebaixamentos rápido para as seções $129+50,135+50$ e dois casos para a seção $138+50$. Como visto anteriormente a seção $132+00$ não é representativa sem a condição de contorno adicional do piezômetro, por esse motivo não foram realizados estudos de caso nesta seção.

\subsection{1}

\section{Seção $129+50$}

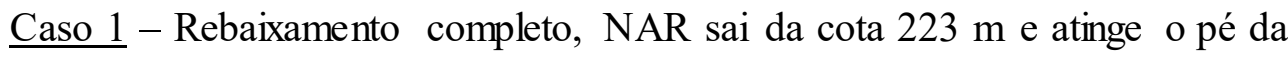
barragem em 57 dias, com uma velocidade de rebaixamento de $13 \mathrm{~cm} /$ dia, maior velocidade praticada no período estudado anteriormente. A Figura 5.4 mostra a variação do fator de segurança e a Figura 5.5 a posição da linha freática para o menor FS.

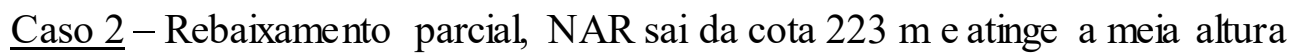
da barragem em 28 dias, com velocidade de rebaixamento de $13 \mathrm{~cm} / \mathrm{dia}$. A Figura 5.6 mostra a variação do fator de segurança e a Figura 5.7 a posição da linha freática para o menor FS.

$\underline{\text { Caso } 3}$ - Rebaixamento parcial, NAR sai da cota 219,30 e atinge o pé da barragem em 28 dias, com velocidade de rebaixamento de $13 \mathrm{~cm} /$ dia. A Figura 5.8 mostra a variação do fator de segurança e a Figura 5.9 a posição da linha freática para o menor FS.

Caso 4 - Rebaixamento completo, NAR sai da cota $223 \mathrm{~m}$ e atinge o pé da barragem da barragem no mesmo dia com velocidade de 7,4 $\mathrm{m} / \mathrm{dia}$ (rebaixamento instantâneo). A Figura 5.10 mostra a variação do fator de segurança e a Figura 5.11 a posição da linha freática para o menor FS. 


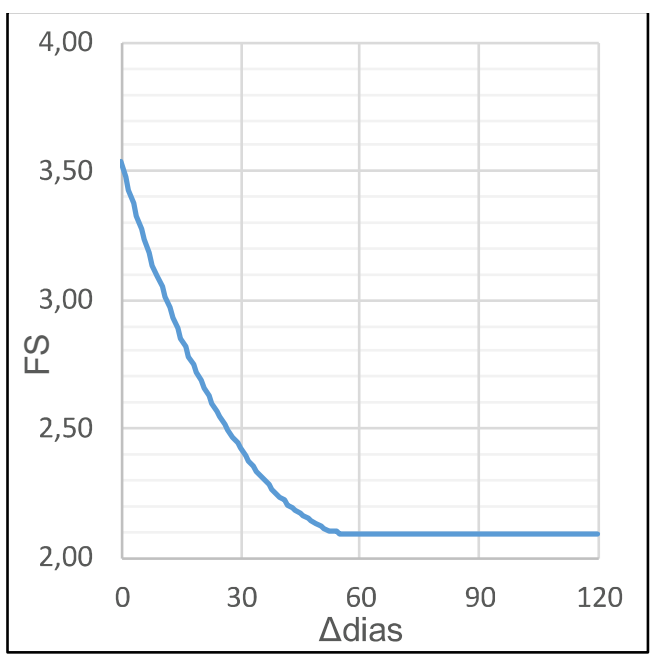

Figura 5.4 - Caso 1 / Fator de segurança para rebaixamento completo da seção 129+50

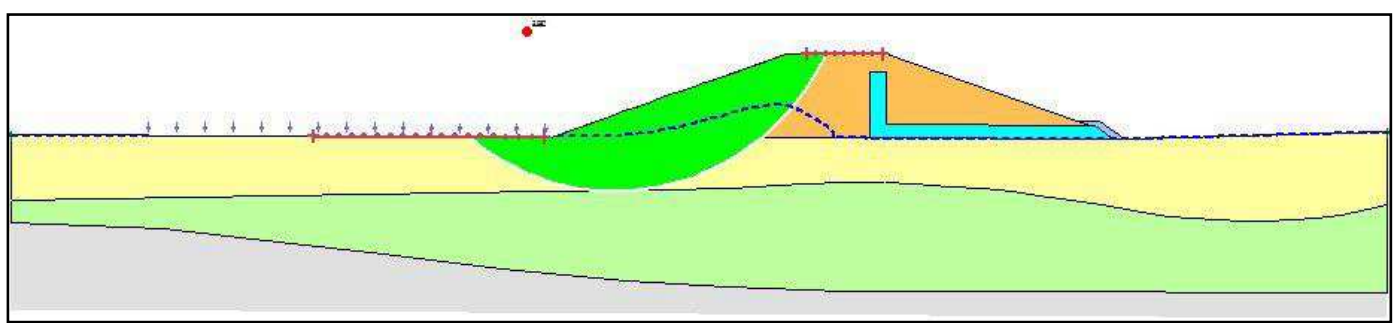

Figura 5.5 - Caso 1 / Linha freática para menor FS durante rebaixamento completo da seção $129+50$

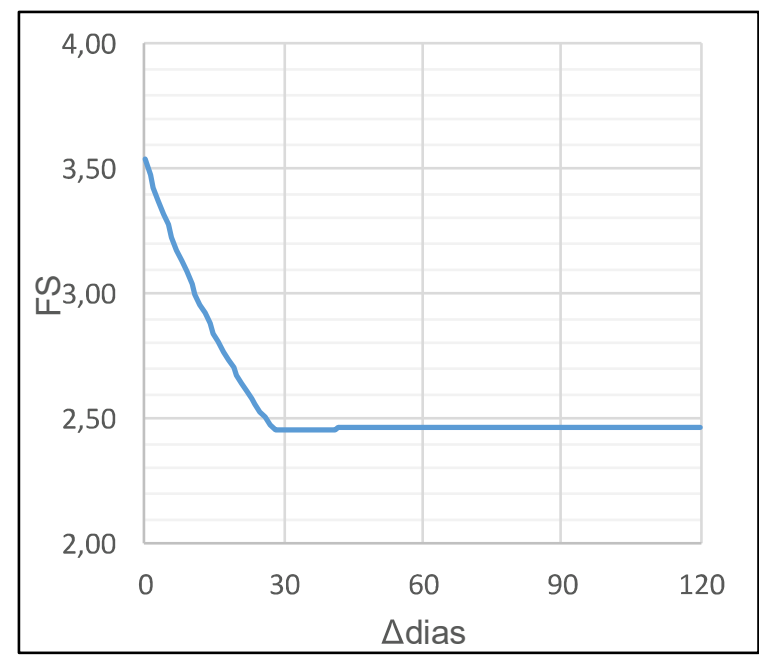

Figura 5.6 - Caso 2 / Fator de segurança para rebaixamento parcial da seção 129+50

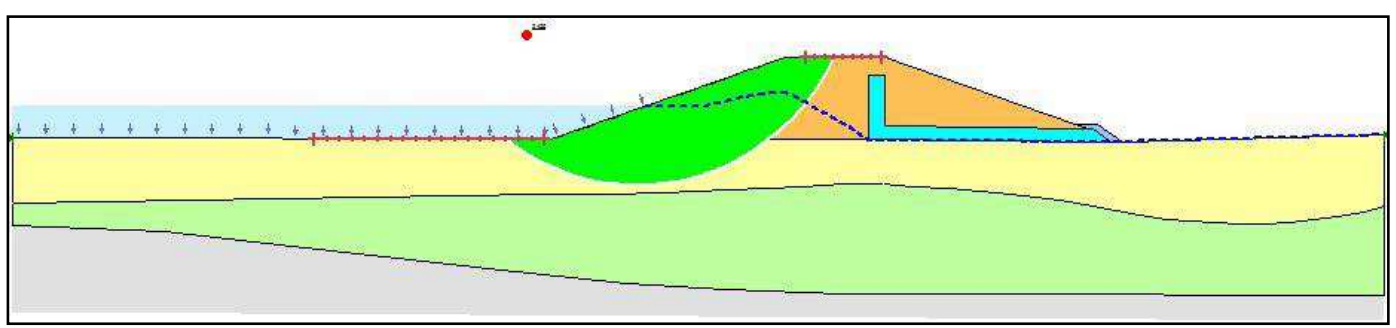

Figura 5.7 - Caso 2 / Linha freática para menor FS durante rebaixamento parcial da seção $129+50$ 


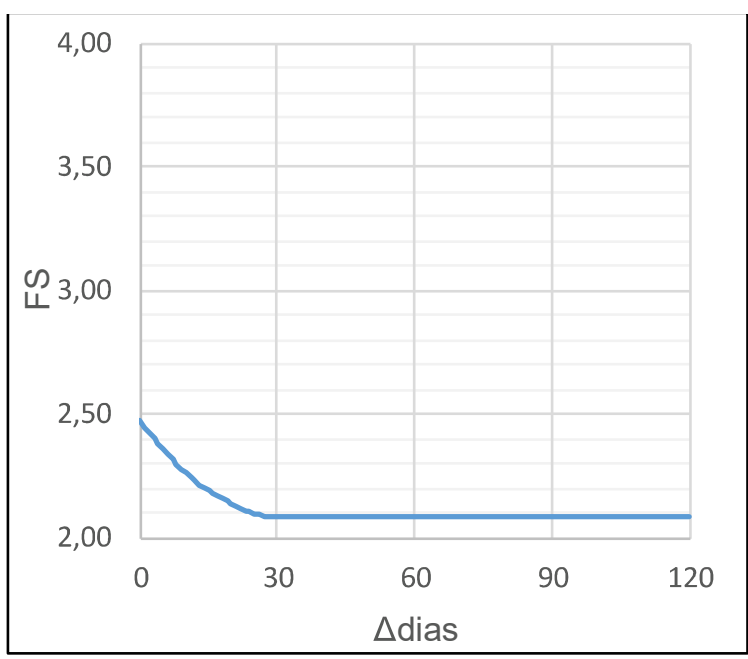

Figura 5.8 - Caso 3 / Fator de segurança para rebaixamento parcial da seção 129+50

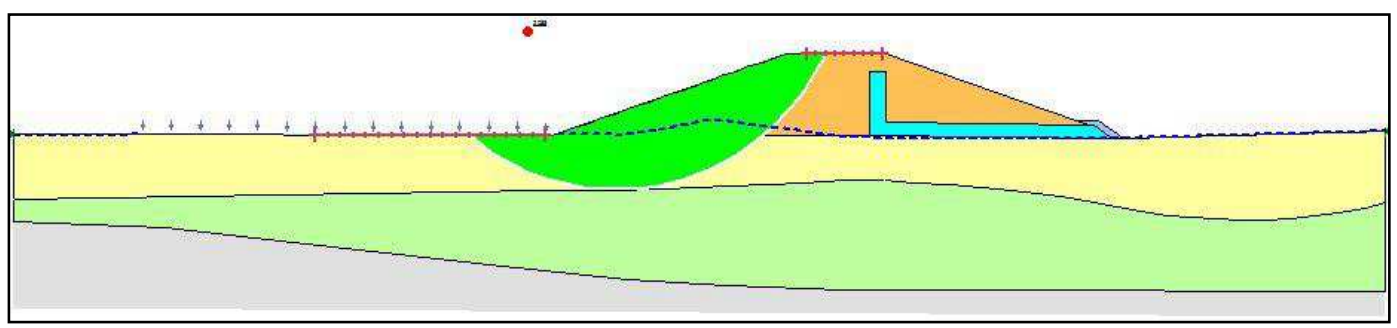

Figura 5.9 - Caso 3 / Linha freática para menor FS durante rebaixamento parcial da seção $129+50$

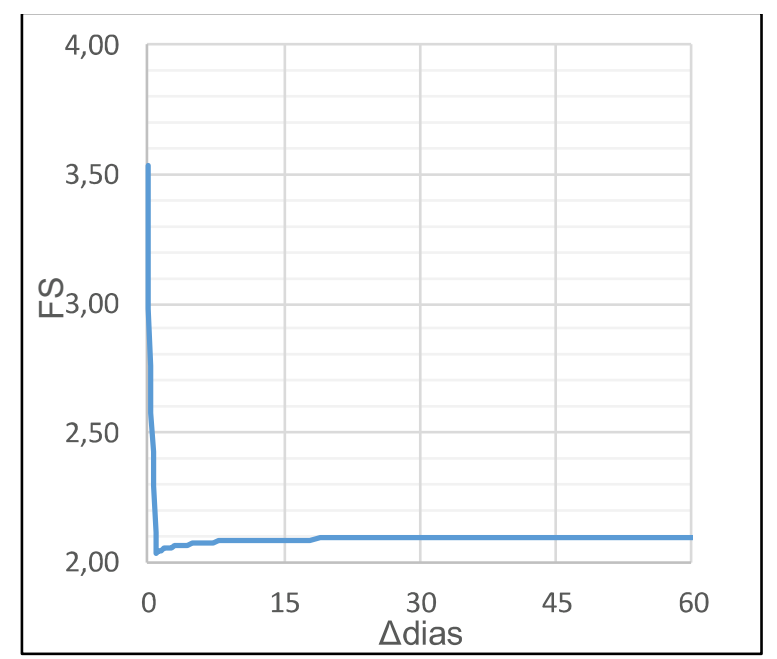

Figura 5.10 - Caso 4 / Fator de segurança para rebaixamento completo da seção 129+50

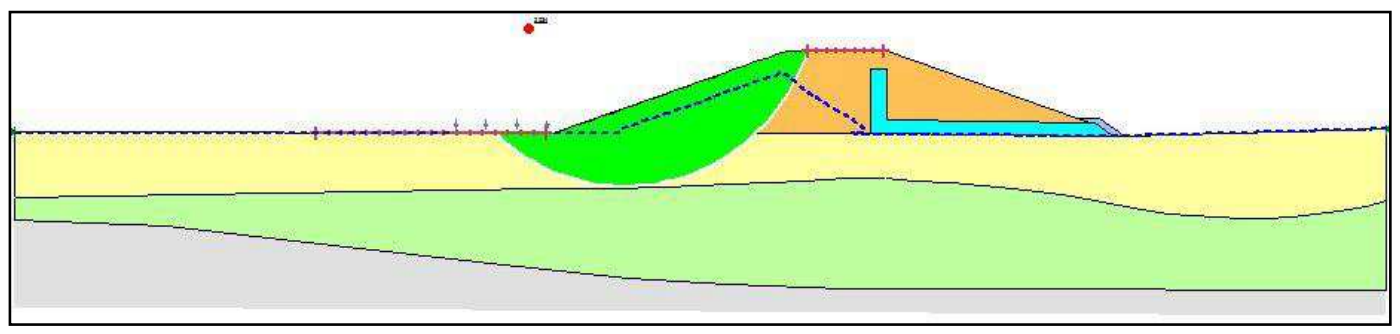

Figura 5.11 - Caso 4 / Linha freática para menor FS durante rebaixamento completo da seção $129+50$ 
A Tabela 5.4 apresenta uma síntese dos dados relevantes de cada um dos casos.

Tabela 5.4 - Variação do FS para os casos de rebaixamento rápido na seção 129+50

\begin{tabular}{lccccc} 
& $\mathrm{FS}_{\text {inicial }}$ & $\mathrm{FS}_{\text {mínimo }}$ & $\mathrm{FS}_{\text {final }}$ & $\Delta \mathrm{FS}_{\text {(inicial-final })}$ & $\Delta \mathrm{FS}_{\text {(mínimo-final }}$ \\
\cline { 2 - 6 } Caso 1 & 3,54 & 2,09 & 2,09 & 1,45 & 0,00 \\
Caso 2 & 3,54 & 2,46 & 2,46 & 1,08 & 0,00 \\
Caso 3 & 2,47 & 2,09 & 2,09 & 0,38 & 0,00 \\
Caso 4 & 3,54 & 2,03 & 2,09 & 1,45 & 0,05 \\
\hline
\end{tabular}

O FS do talude de montante está diretamente relacionado ao NAR. Sendo assim, é esperado que com a redução do NAR, o FS também sofra um decréscimo, cuja redução é representada nas curvas acima pelos fatores de segurança iniciais e finais.

Entretanto os fatores de segurança entre o FS inicial e o FS final podem se comportar de maneira diferente de acordo com a velocidade do rebaixamento. No caso 4, que ocorre um rebaixamento muito rápido, a tensão imposta pelo reservatório é reduzida bruscamente, enquanto as poropressões no maciço compactado são mantidas e se dissipam em uma velocidade menor. Isso faz com que o FS no instante do rebaixamento fique abaixo do FS final e com a dissipação lenta das poropressões ele aumenta até chegar no FS final.

Esse pico do FS abaixo do final não ocorre nos $\operatorname{casos} 1,2$ e 3 , pois a velocidade de rebaixamento é consideravelmente menor e a dissipação, apesar de não acompanhar a velocidade de rebaixamento do NAR, acontece de maneira rápida a ponto de não provocar queda considerável no FS.

\section{2 .2}

\section{Seção $135+50$}

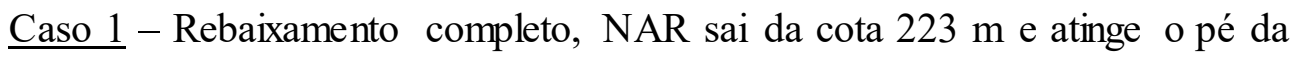
barragem em 62 dias, com uma velocidade de rebaixamento de $13 \mathrm{~cm} /$ dia, maior velocidade praticada no período estudado anteriormente. A Figura 5.12 mostra a variação do fator de segurança e a Figura 5.13 a posição da linha freática para o menor FS. 


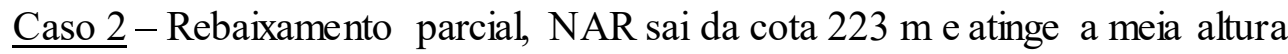
da barragem em 31 dias, com velocidade de rebaixamento de $13 \mathrm{~cm} /$ dia. A Figura 5.14 mostra a variação do fator de segurança e a Figura 5.15 a posição da linha freática para o menor FS.

$\underline{\text { Caso } 3}$ - Rebaixamento parcial, NAR sai da cota 219 e atinge o pé da barragem em 31 dias, com velocidade de rebaixamento de $13 \mathrm{~cm} /$ dia. A Figura 5.16 mostra a variação do fator de segurança e a Figura 5.17 a posição da linha freática para o menor FS.

$\underline{\text { Caso } 4}$ - Rebaixamento completo, NAR sai da cota $223 \mathrm{~m}$ e atinge o pé da barragem da barragem no mesmo dia com velocidade de $8 \mathrm{~m} /$ dia. A Figura 5.18 mostra a variação do fator de segurança e a Figura 5.19 a posição da linha freática para o menor FS.

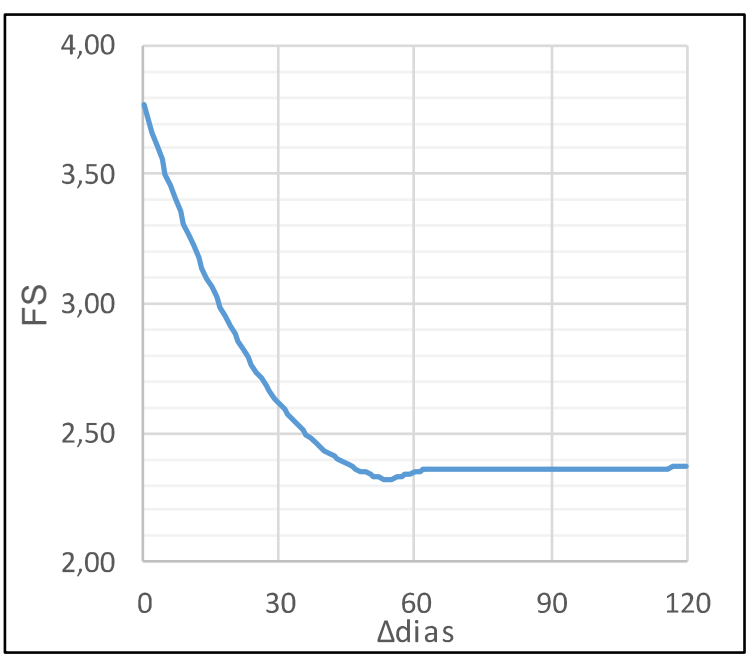

Figura 5.12 - Fator de segurança para rebaixamento completo da seção $135+50$

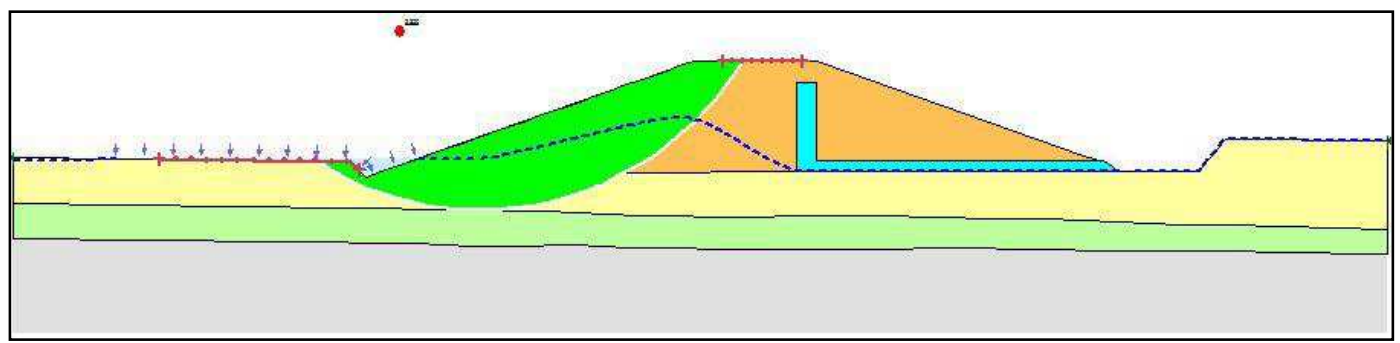

Figura 5.13 - Caso 1 / Linha freática para menor FS durante rebaixamento completo da seção $135+50$ 


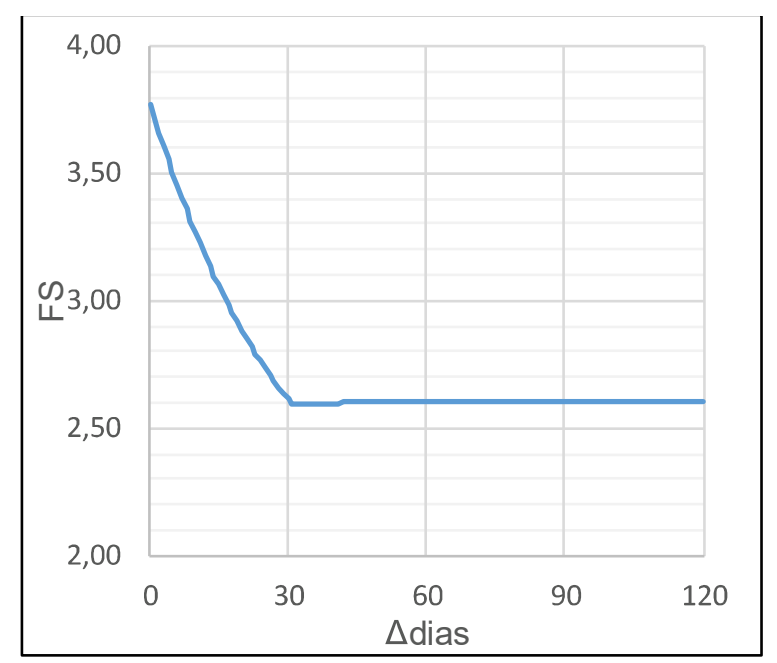

Figura 5.14 - Caso 2 / Fator de segurança para rebaixamento parcial da seção 135+50

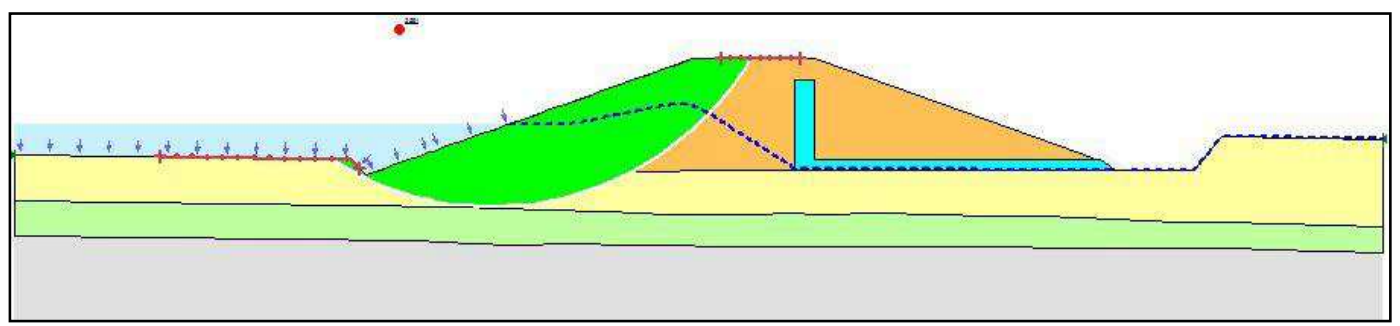

Figura 5.15 - Caso 2 / Linha freática para menor FS durante rebaixamento parcial da seção $135+50$

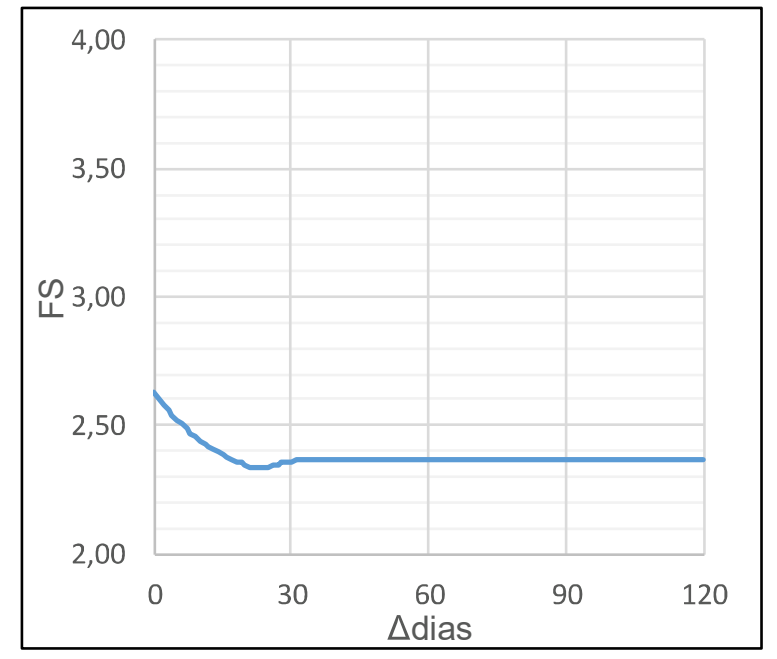

Figura 5.16 - Caso 3 / Fator de segurança para rebaixamento parcial da seção 135+50

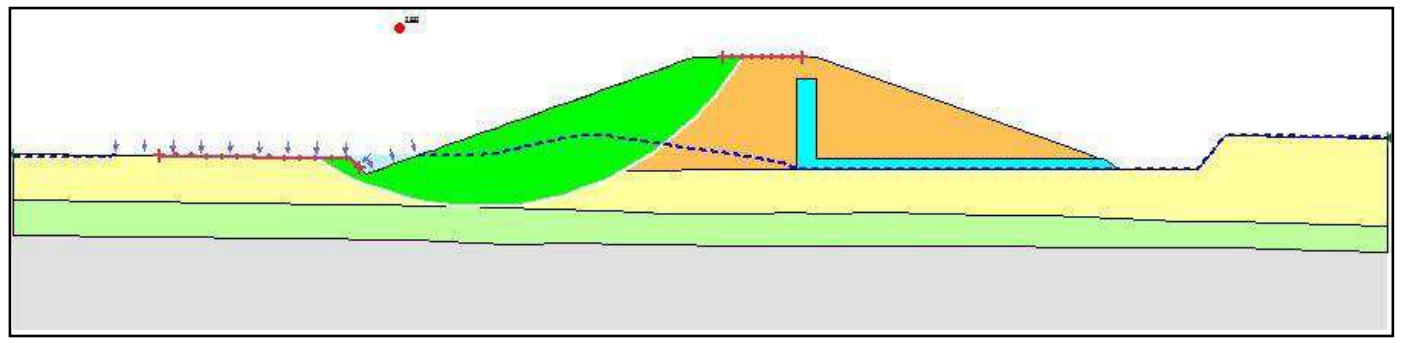

Figura 5.17 - Caso 3 / Linha freática para menor FS durante rebaixamento parcial da seção $135+50$ 


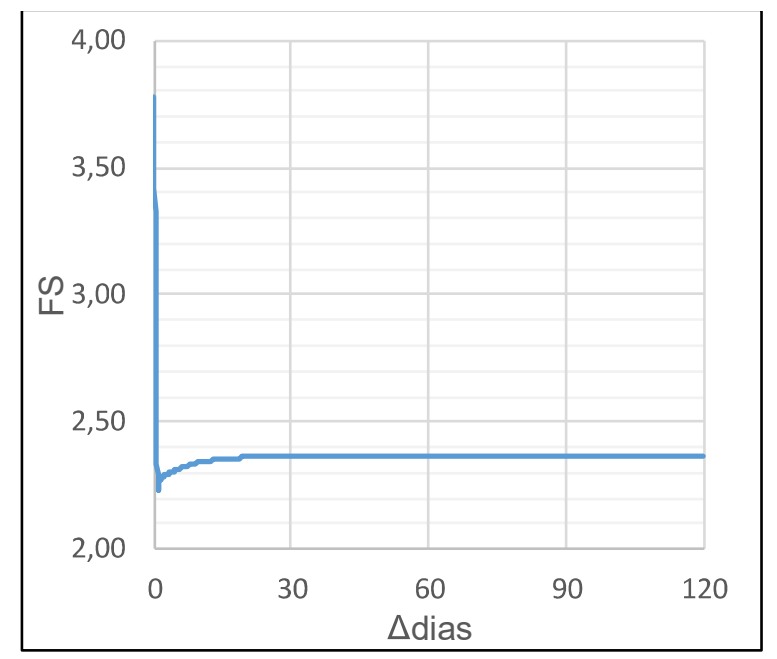

Figura 5.18 - Caso 4 / Fator de segurança para rebaixamento completo da seção 135+50

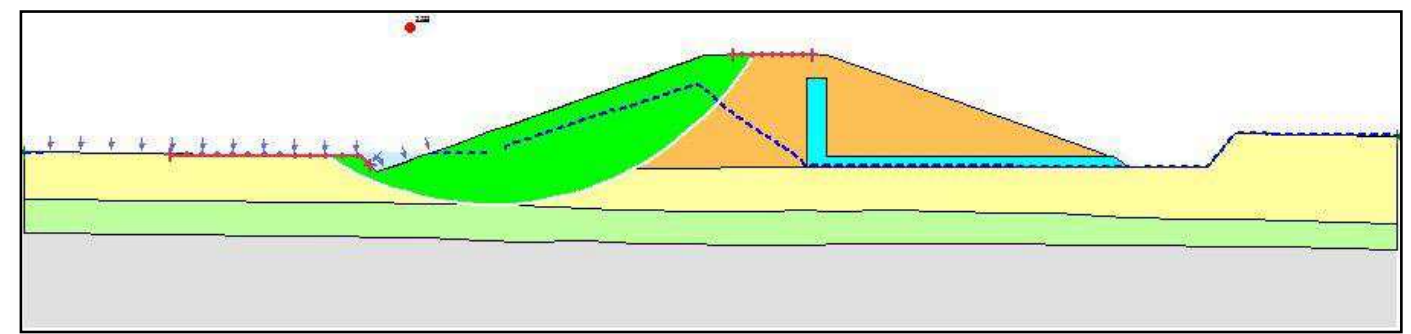

Figura 5.19 - Caso 4 / Linha freática para menor FS durante rebaixamento rápido da seção $135+50$

A Tabela 5.5 apresenta uma síntese dos dados relevantes de cada um dos casos.

Tabela 5.5 - Variação do FS para os casos de rebaixamento rápido na seção 135+50

\begin{tabular}{lccccc} 
& $\mathrm{FS}_{\text {inicial }}$ & $\mathrm{FS}_{\text {mínimo }}$ & $\mathrm{FS}_{\text {final }}$ & $\Delta \mathrm{FS}$ (inicial-final) & $\Delta \mathrm{FS}$ (mínimo-final) \\
\cline { 2 - 6 } Caso 1 & 3,77 & 2,32 & 2,37 & 1,40 & 0,05 \\
Caso 2 & 3,77 & 2,59 & 2,61 & 1,16 & 0,02 \\
Caso 3 & 2,63 & 2,33 & 2,37 & 0,26 & 0,04 \\
Caso 4 & 3,77 & 2,23 & 2,37 & 1,40 & 0,14 \\
\hline
\end{tabular}

Diferentemente do que ocorre na seção $129+50$, nota-se um pico do FS abaixo do FS final no rebaixamento de $13 \mathrm{~cm} /$ dia (casos 1,2 e 3). Isso ocorre, pois, a camada de solo na fundação é menor e consequentemente a linha freática no maciço compactado é mais alta, sendo assim, existem mais poropressões a serem dissipadas no maciço compactado e a camada de solo mais permeável (fundação) que ajuda essa dissipação é menor. 
No caso 4, que a velocidade de rebaixamento é maior, o fenômeno é mais acentuado e a variação entre o FS mínimo e final é de 0,14 . Nos casos com velocidade menor a redução do FS devido rebaixamento rápido foi de, no máximo, 0,05 .

\section{2 .3}

\section{Seção $138+50$}

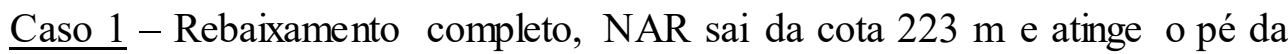
barragem em 30 dias, com uma velocidade de rebaixamento de $13 \mathrm{~cm} /$ dia, maior velocidade praticada no período estudado anteriormente. A Figura 5.20 mostra a variação do fator de segurança e a Figura 5.21 a posição da linha freática para o menor FS.

$\underline{\text { Caso } 2}$ - Rebaixamento completo, NAR sai da cota $223 \mathrm{~m}$ e atinge o pé da barragem da barragem em 12 horas, com velocidade de 8 m/dia. A Figura 5.22 mostra a variação do fator de segurança e a Figura 5.23 a posição da linha freática para o menor FS.

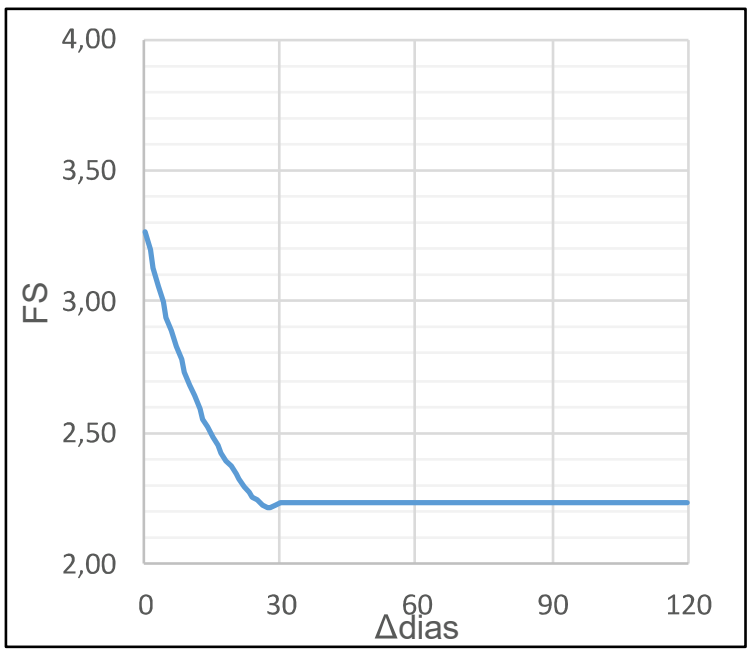

Figura 5.20 - Caso 1 / Fator de segurança para rebaixamento completo da seção 138+50

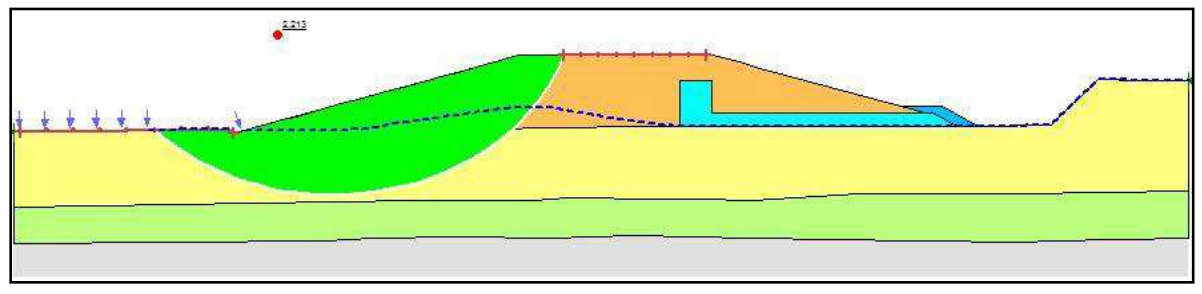

Figura 5.21 - Caso 1 / Linha freática para menor FS durante rebaixamento completo da seção $138+50$ 


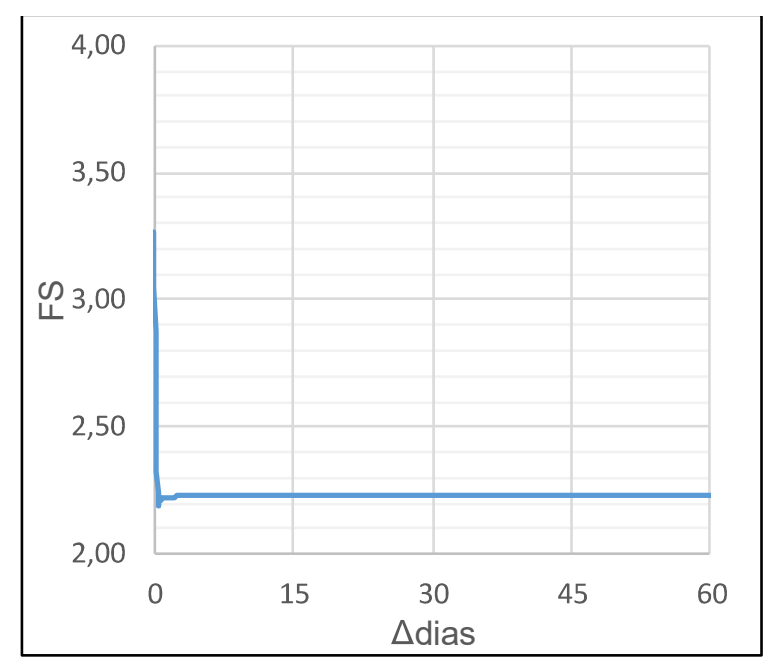

Figura 5.22 - Caso 2 / Fator de segurança para rebaixamento completo da seção 138+50

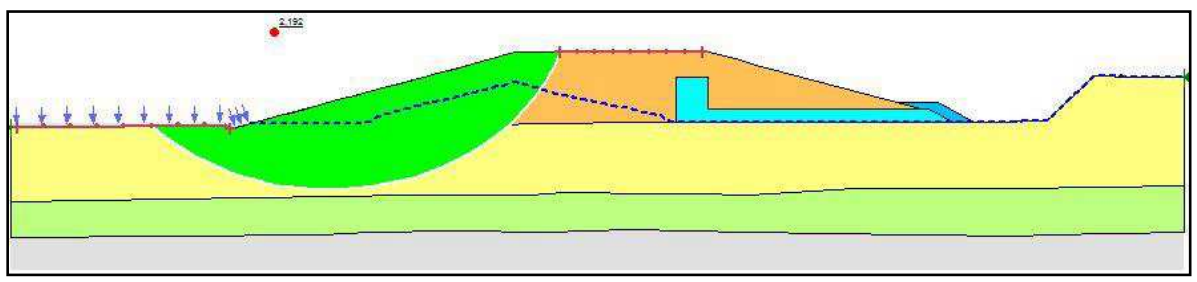

Figura 5.23 - Caso 2 / Linha freática para menor FS durante rebaixamento completo da seção $138+50$

A Tabela 5.6 apresenta uma síntese dos dados relevantes de cada um dos casos.

Tabela 5.6 - Variação do FS para os casos de rebaixamento rápido na seção 138+50

\begin{tabular}{lccccc} 
& $\mathrm{FS}_{\text {inicial }}$ & $\mathrm{FS}_{\text {mínimo }}$ & $\mathrm{FS}_{\text {final }}$ & $\Delta \mathrm{FS}$ (inicial-final) & $\Delta \mathrm{FS}_{\text {(mínimo-final) }}$ \\
\cline { 2 - 6 } Caso 1 & 3,27 & 2,21 & 2,23 & 1,03 & 0,02 \\
Caso 2 & 3,27 & 2,19 & 2,23 & 1,03 & 0,04 \\
\hline
\end{tabular}

Nesta seção o efeito do rebaixamento rápido é mais notável que na seção 129+50, devido a menor camada de fundação, e, menos acentuado que na seção $135+50$, devido a menor altura.

\section{3}

\section{Obstruções}

O núcleo da barragem de Itaipu foi construído com solo laterítico de áreas basálticas e o sistema de drenagem com areia artificial. Em algumas barragens construídas com material semelhante, existem registros de problemas relacionados à colmatação química do sistema de drenagem, devido à precipitação de óxidos de ferro. 
Outro problema inerente ao tipo de material é a obstrução da saída do tapete drenante, devido à alteração e decomposição dos blocos de rocha basáltica bastante intemperizáveis.

Nas análises anteriores verificou-se que o fluxo na BTME ocorre predominantemente pela fundação, sendo o sistema de drenagem interna pouco utilizado. Entretanto, optou-se em simular obstruções no sistema de drenagem da seção mais alta e com menor camada de fundação.

Nessas simulações, assim como nos demais estudos de caso, o nível d'água a jusante foi considerado coincidindo com o terreno. Como se trata de hipóteses, é incoerente manter a condição de contorno do nível d'água a jusante, visto que não é possível prever como o mesmo se comportará sob as circunstâncias simuladas. A consideração do nível d'água no terreno é uma opção conservadora.

Foram realizadas duas simulações no sistema de drenagem, a primeira apenas da saída do tapete drenante e a segunda do sistema de drenagem inteiro (dreno vertical + tapete drenante). A partir das simulações verificou-se o comportamento da linha freática, dos piezômetros e do FS do talude de jusante.

Para o primeiro caso, verificou-se que a obstrução da saída do tapete drenante provocaria um alteamento da linha freática no maciço, que poderia provocar surgências no talude de jusante (Figura 5.24). As poropressões e o peso exercido por esse aumento da linha freática não causariam queda substancial no FS do talude, que cairia de 1,94 para 1,80 .

Com a obstrução, parte do fluxo que era escoado pelo sistema de drenagem iria passar para a camada de fundação, que passa a ser o material mais permeável da estrutura. Tal fato seria sentido pelo piezômetro localizado embaixo do maciço compactado, que aumentaria em torno de 1,45 m em comparação com condições normais de operação.

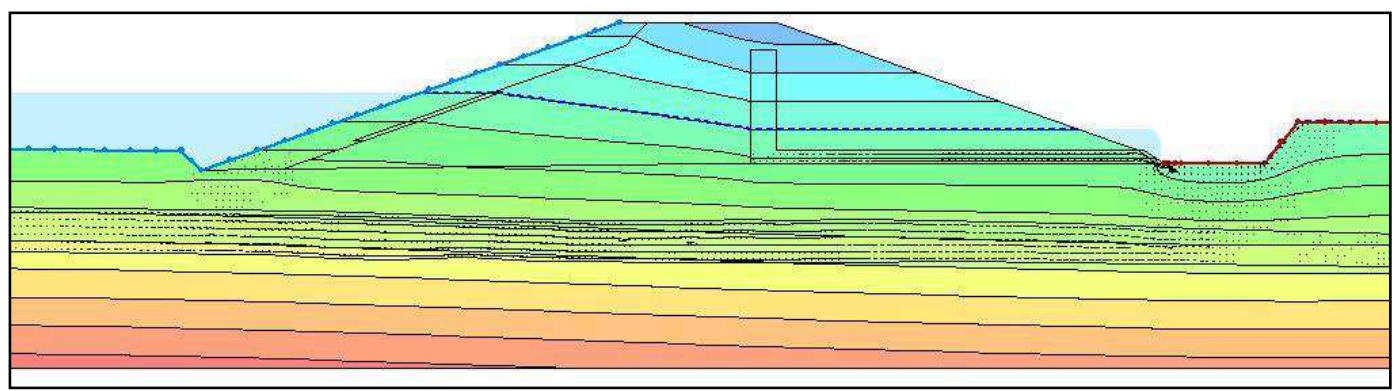

Figura 5.24 - Saída do tapete drenante obstruído 
No caso de obstrução completa do sistema de drenagem, ocorreria o mesmo fenômeno do caso anterior, porém, em maior proporção. O nível freático subiria e provocaria surgências no talude de jusante (Figura 5.25). O FS do talude seria reduzido de 1,94 para 1,71. O piezômetro localizado abaixo do maciço compactado teria um incremento de carga de aproximadamente $1,70 \mathrm{~m}$.

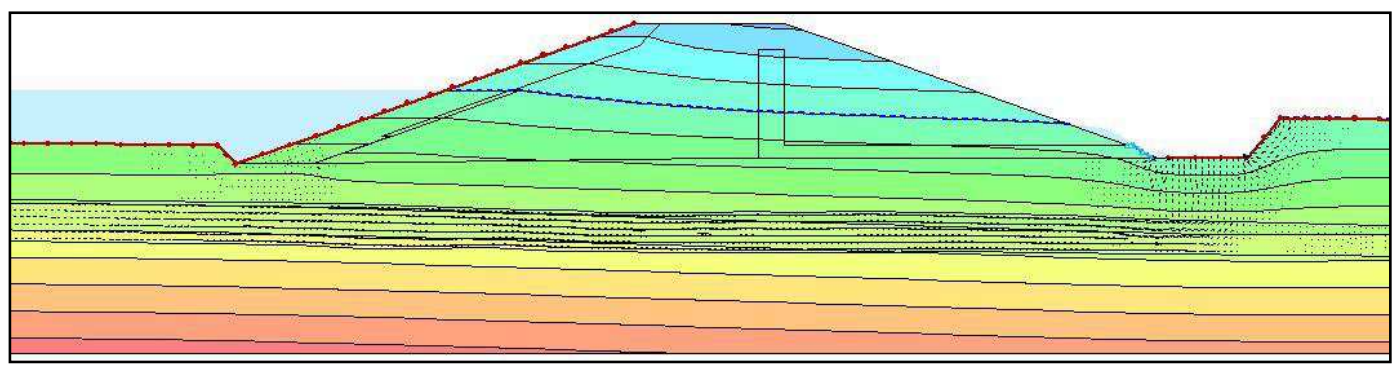

Figura 5.25 - Sistema de drenagem obstruído

Verificou-se em ambas situações que a estabilidade do talude de jusante é garantida mesmo com a obstrução do sistema de drenagem. Entretanto, uma obstrução poderia causar o fenômeno de piping no maciço compactado ou na fundação devido ao incremento das forças de percolação.

A obstrução pode ser detectada com o aumento expressivo dos piezômetros na fundação e/ou de surgências na superfície do talude ou terreno a jusante. 


\section{6 Conclusões e Sugestões para Futuros Trabalhos}

\section{1 \\ Conclusões}

Com a comparação dos resultados da simulação com as poropressões medidas em campo, julga-se que o modelo representou satisfatoriamente as condições de campo.

Nas análises de fluxo foi possível constatar que a maior vazão pela barragem ocorre na camada de saprolito da fundação. Por isso, mesmo em seções com alturas semelhantes, as poropressões se comportam de maneira diferente. Quanto maior a espessura da camada de fundação, maior o fluxo e maior a variação das poropressões.

Consequentemente, a linha freática no corpo da barragem também é função da espessura da camada de solo na fundação. Com uma camada de fundação espessa, o fluxo se dá principalmente pela fundação e o maciço compactado fica pouco saturado. Conforme a camada de solo na fundação diminui, a linha freática tende a subir e aumenta o fluxo pelo maciço compactado.

As poropressões estão diretamente relacionadas ao nível do reservatório e a espessura da fundação. Os piezômetros instalados na camada de saprolito não apresentaram defasagem de tempo entre a alteração do NAR e a resposta do instrumento ao NAR. Contudo os piezômetros instalados na argila da fundação apresentaram defasagem de aproximadamente quatro dias.

Em diversos momentos durante o período estudado, verificou-se rebaixamentos considerados rápidos, quando o rebaixamento da linha freática no maciço compactado não acompanha o rebaixamento do NAR devido a lenta dissipação de poropressões. O caso mais notável foi em outubro de 2014, quando o rebaixamento do NAR teve uma taxa de $13 \mathrm{~cm} / \mathrm{dia}$.

As análises de estabilidade mostraram que a variação do FS do talude de montante se correlaciona positivamente com a variação do NAR. A contribuição do peso do reservatório para estabilidade do talude é o principal fator para essa 
variação. Por esse motivo, quando o NAR atinge cotas próximas ao pé da barragem, a variação do FS é menor pois a influência do peso é menor. Quando o NAR fica abaixo do pé da barragem, a correlação passa a ser inversa e o FS aumenta com a redução do NAR. Isso ocorre visto que a redução da linha freática na fundação e a consequente diminuição das poropressões contribuem para o incremento da tensão efetiva e da estabilidade do maciço.

O rebaixamento rápido corresponde a uma pequena parcela da variação do FS do talude de montante. Essa variação no FS ocorre em função da velocidade do rebaixamento, da área saturada do maciço e da espessura da camada de fundação. Na seção 129+50, por exemplo, essa variação no FS com o rebaixamento rápido é amenizada devido à espessa camada de fundação que acelera a dissipação. Nas demais seções a variação é sensivelmente mais notável, mas em todos os casos o fator determinante para a variação do FS é o peso do reservatório.

A variação do FS no talude de jusante ocorre principalmente devido à variação das poropressões na fundação, visto que não ocorre fluxo na área do maciço compactado a jusante do dreno. Neste caso, o peso do reservatório contribui para a instabilidade do talude, entretanto, a influência é menor que no talude de montante. Desta forma o FS apresenta correlação negativa com o NAR, ou seja, com o aumento do NAR o FS é diminuído.

Os fatores de segurança críticos podem ocorrer em datas distintas para cada seção de acordo com a altura da seção e a espessura da camada de fundação. Durante todo período estudado os fatores de segurança dos taludes de montante e jusante estiveram acima de 2,0. A seção mais crítica é a 135+50 que chegou nos fatores de segurança mínimo de 2,4 para o talude de montante, no dia 31 de outubro de 2014 durante um rebaixamento rápido, e 2,11 para o talude de jusante no mês de junho de 2014 quando o reservatório atingia cotas superiores a $220 \mathrm{~m}$.

Nas análises probabilísticas verificou-se que a utilização do NAR como variável aleatória não altera o índice de confiabilidade do fator de segurança em nenhuma das seções. A seção 129+50 foi a que apresentou maior probabilidade de ruptura, de $0,3 \%$, devido à sua espessa camada de solo na fundação comparada com as demais seções. O ângulo de atrito efetivo da argila de fundação foi a variável que mais contribuiu para a variância do fator de segurança. Ressalta-se que por possuir poucos resultados de ensaios da argila de fundação, o coeficiente de variação utilizado foi um valor típico sugerido pela bibliografia. 
Os deslocamentos verticais na crista da barragem apontados pelas simulações não corresponderam ao menos à tendência verificada em campo. As simulações mostram que não ocorre adensamento primário, apenas pequenos deslocamentos que são atribuídos a deformações elásticas do maciço compactado e fundação.

Nas proximidades da seção 135+50, onde o marco de referência MR-L-23 apresenta uma tendência de recalque com aproximadamente $30 \mathrm{~mm}$, os recalques devido à deformação elástica foram de aproximadamente $0,5 \mathrm{~mm}$.

\section{2 \\ Sugestões para Futuros Trabalhos}

Com este trabalho foi possível verificar as condições de fluxo e estabilidade de um trecho da BTME durante um período de operação, entretanto, não foram apontadas as causas do recalque detectado pela instrumentação.

Sugere-se para trabalhos futuros uma análise mais detalhada do material do maciço compactado e fundação, com coleta de novas amostras para novos ensaios e análises considerando alteração do material e diferentes modelos constitutivos.

As análises realizadas contemplam apenas um trecho da BTME, é importante que as mesmas sejam replicadas no restante da barragem, inclusive, com ênfase na análise de estabilidade probabilística que foi rapidamente abordada neste trabalho. 


\section{7 \\ Referências Bibliográficas}

Almeida, P. F. D. (2013). Análise de estabilidade de barragens de aterro em fase de esvaziamento. Dissertação de Mestrado. Faculdade de Ciências e Tecnologia, Universidade Nova de Lisboa.

Baecher, G. B., \& Christian, J. T. (2003). Reliability and statis tics in geotechnical engineering. John Wiley \& Sons.

Biot, M. A. (1941). General theory of three-dimensional consolidation. Journal of applied physics, 12(2), 155-164.

Bishop, A. W., \& Henkel, D. J. (1957). The measurement of soil properties in the triaxial test. Edward Arnold (Publishers) Ltd; London.

Bishop, A. W. (1955). The Use of the Slip Circle in the Stability Analysis of Slopes. Géotechnique vol. $5 \mathrm{n}^{\mathrm{o}} 1$.

Casagrande, A. (1937). Seepage through dams. Journal of the New England Water Works Association, $n^{\circ} 209$, Série $n^{0} 5$.

Cedergren, H. R. (1997). Seepage, drainage, and flow nets. John Wiley \& Sons.

Centrais Elétricas de São Paulo S.A. (CESP). (1975). Ensaios geotécnicos sobre amostras indeformadas extraídas da fundação da barragem - M.E. e sobre amostras deformadas das áreas de empréstimo 'Dois Irmãos' e 'Área de escavação da fundação da barragem de enrocamento' - Usina de Itaipu Estado do Paraná. Documento interno de Itaipu, SAT 2063.50.001.P.

- (1976a). Ensaios geotécnicos sobre amostras indeformadas da fundação da barragem de terra - margem esquerda e dos aterros experimentais e sobre amostras deformadas das áreas de empréstimo 'Dois Irmãos' e da 'Escavação da fundação da barragem de enrocamento'- Usina de Itaipu - Estado do Paraná. Documento interno de Itaipu, SAT 2063.50.0253.P.

1976b. Ensaios Geotécnicos Sobre Amostras Indeformadas Extraídas Da Fundação Da Barragem de Terra de Itaipu - M.E. Documento interno de Itaipu, SAT 2063.50.0252.P.

Christian, J. T., Ladd, C. C., \& Baecher, G. B. (1994). Reliability applied to slope stability analysis. Journal of Geotechnical Engineering, 120(12), 2180-2207.

Cook, R. D. et al. (1989). Concepts and applications of finite element analysis ( $3^{\mathrm{a}}$ Ed.). John Wiley \& Sons. 
Cruz, P. T. (1996). 100 barragens brasileiras: casos históricos, materiais de construção, projeto. São Paulo: Oficina de Textos.

Duncan, J. M. (1993). Limitations of conventional analysis of consolidation settlement. Journal of geotechnical engineering, 119(9), 1333-1359.

Duncan, J. M., Wright, S. G., \& Brandon, T. L. (2014). Soil strength and slope stability. John Wiley \& Sons.

Figueiredo Filho, D. B., \& Junior, J. A. S. (2010). Desvendando os Mistérios do Coeficiente de Correlação de Pearson (r). Revista Política Hoje-ISSN: 01047094, 18(1).

Fredlund, D. G., \& Krahn, J. (1977). Comparison of slope stability methods of analysis. Canadian Geotechnical Journal, 14(3), 429-439.

Fredlund, D. G., \& Rahardjo, H. (1993). Soil mechanics for unsaturated soils. John Wiley \& Sons.

GEO-SLOPE International, Ltd. (2012). Seepage Modeling with SEEP/W. Geostudio Helpfile.

GEO-SLOPE International, Ltd. (2013). Stress-Deformation Modeling with SIGMA / W. Geostudio Helpfile.

Hvorslev, M. J. (1951). Time lag and soil permeability in ground-water observations. Waterways Experiment Station - U.S. Army Corps of Engineers, Bulletin $n^{\circ} 36$.

International Engineering Company (IECO) \& Enerconsult Engenharia Ltda (ELC) (1977). Aprovechamiento Hidroelectrico de Itaipu - Presa de Tierra Margen Izquierda y Transicion con la Presa de Enrocado - Informe final del proyecto. Arquivo interno de Itaipu, SAT 4280.50.8003-E.

1982. Barragem de terra e de transição - M.E. - Maciço de argila plástica - relatório final. Arquivo interno de Itaipu, SAT 2061.50.1757.P.

1992. Aprovechamento Hidroelectrico de Itaipu - Presa de Tierra de la Margen Izquierda - Informe geotecnico final - Sintesis de los parametros geotecnicos y analisis de estabilidad del macizo. Arquivo interno de Itaipu, SAT 4280.50.8007.E.

1995. Relatório do histórico do desempenho das estruturas e suas fundações. Documento interno de Itaipu, SAT 4006.50.0024.P.

Itaipu Binacional (2009). Usina Hidrelétrica de Itaipu: Aspectos de Engenharia. Foz do Iguaçu.

Jansen, R. B. (1922). Advanced dam engineering for design, construction, and rehabilitation. Van Nostrand Reinhold, New York.

Knappett, J. A., \& Craig, R. F. (2012). Craig's soil mechanics. Spon Press. 
Kochen, R., \& de Zagottis, D. (1983). Conceitos Básicos sobre a Teoria Tridimensional do Adensamento. Publicação da Escola Politécnica de São Paulo.

Kutzner, C. (1997). Earth and Rockfill Dams: Principles for Design and Construction. CRC Press.

Lambe, T. W., \& Whitman, R. V. (1969). Soil Mechanics. Jhon Wiley \& Sons.

Mafioleti, T. R. (2016). Proposta para análise probabilística de estabilidade de barragens de terra por método de confiabilidade estrutural aplicada aos fatores de segurança FS de Janbu e de Bishop. Tese de Doutorado. Universidade Federal do Paraná - UFPR.

Mesri, G., \& Choi, Y. K. (1985). Settlement analysis of embankments on soft clays. Journal of Geotechnical Engineering, 111(4), 441-464.

Mitchell, J. K., \& Soga, K. (2005). Fundamentals of soil behavior. John Wiley \& Sons.

Moregenstern, N. (1963). Stability charts for earth slopes during rapid drawdown. Geotechnique, 13(2), 121-131.

Patias, J. et al. (2015). Vazões de Infiltração Através Da Barragem de Itaipu. XXX Seminário Nacional de Grandes Barragens, Foz do Iguaçu - PR.

Penman, A. D. M. (1986). On the Embankment Dam. Géotechnique 36 (3), 303348.

Pinto, C. D. S. (2006). Curso básico de mecânica dos solos em 16 aulas ( $3^{\mathrm{a}}$ Ed.). São Paulo: Oficina de Textos.

Sandroni, S. S., \& Sayão, A. S. F. J. (1992). Avaliação estatística do coeficiente de segurança de taludes. $1^{\text {a }}$ Conferência Brasileira sobre Estabilidade de Encostas, Rio de Janeiro, ABMS (Vol. 2, pp. 523-535).

Sayão, A.S.F.J., Sandroni, S.S., Fontoura, S.A.B., \& Ribeiro, R.C.H. (2012). Considerations on the Probability of failure of mine slopes. Soils \& Rocks, 2012, 35: 31-37.

Silva, C. C. (2015). Análise de estabilidade de um talude da cava de Alegria utilizando abordagem probabilística. Dissertação de Mestrado. Universidade Federal de Ouro Preto - UFOP.

Silveira, J. F. A. (2006). Instrumentação e segurança de barragens de terra e enrocamento. Oficina de Textos: São Paulo.

Singh, B., \& Varshney, R. (1995). Enginnering for Embankment Dams. A.A. Balkema. 
Terzaghi, K. (1925). Principles of soil mechanics, IV - Settlement and consolidation of clay. Engineering News-Record, 95(3), 874-878.

Terzaghi, K. (1936). The shearing resistance of saturated soils and the angle between the planes of shear. Proceedings of the 1 st international conference on soil mechanics and foundation engineering. Harvard University Press Cambridge, MA, 1936. p. 54-56.

Thá, P. C. (2007). Estudos das condições de fluxo pela Barragem de Terra da Margem Esquerda de Itaipu. Dissertação de Mestrado. Pontificia Universidade Católica do Rio de Janeiro - PUC-Rio.

Themag Engenharia \& Grupo Alto Paraná (1990). Aproveitamento Hidrelétrico de Itaipu - Sistema de Operação E Manutenção Das Obras Civis - Descrição de Funcionamento - Barragem de Terra. Relatório interno de Itaipu, SAT 1963.50.7012.P.

U.S. Army Corps of Engineering (1995). Instrumention of Embankment Dams and Levees. Engineer Manual. 


\section{Anexos}

Anexo I - Regressão linear realizada nos gráficos p'x q para os ensaios UU (Q), CU (R), CUsat (Rsat) e CD (S) com amostras do maciço compactado.

Anexo II - Resultados de ensaios de adensamento realizados com amostras do maciço compactado.

Anexo III - Planta da instrumentação da BTME.

Anexo IV - Plantas do sistema de drenagem superficial da BTME.

Anexo V - Localização dos marcos de referência na BTME.

Anexo VI - Geometria das seções estudadas.

Anexo VII - Instrumentação das seções estudadas. 
Anexo I - Regressão linear realizada nos gráficos p'x q para os ensaios UU (Q), CU (R), CUsat (Rsat) e CD (S) com amostras do maciço compactado. 


\section{ENSAIO TRIAXIAL $\bar{Q}$}

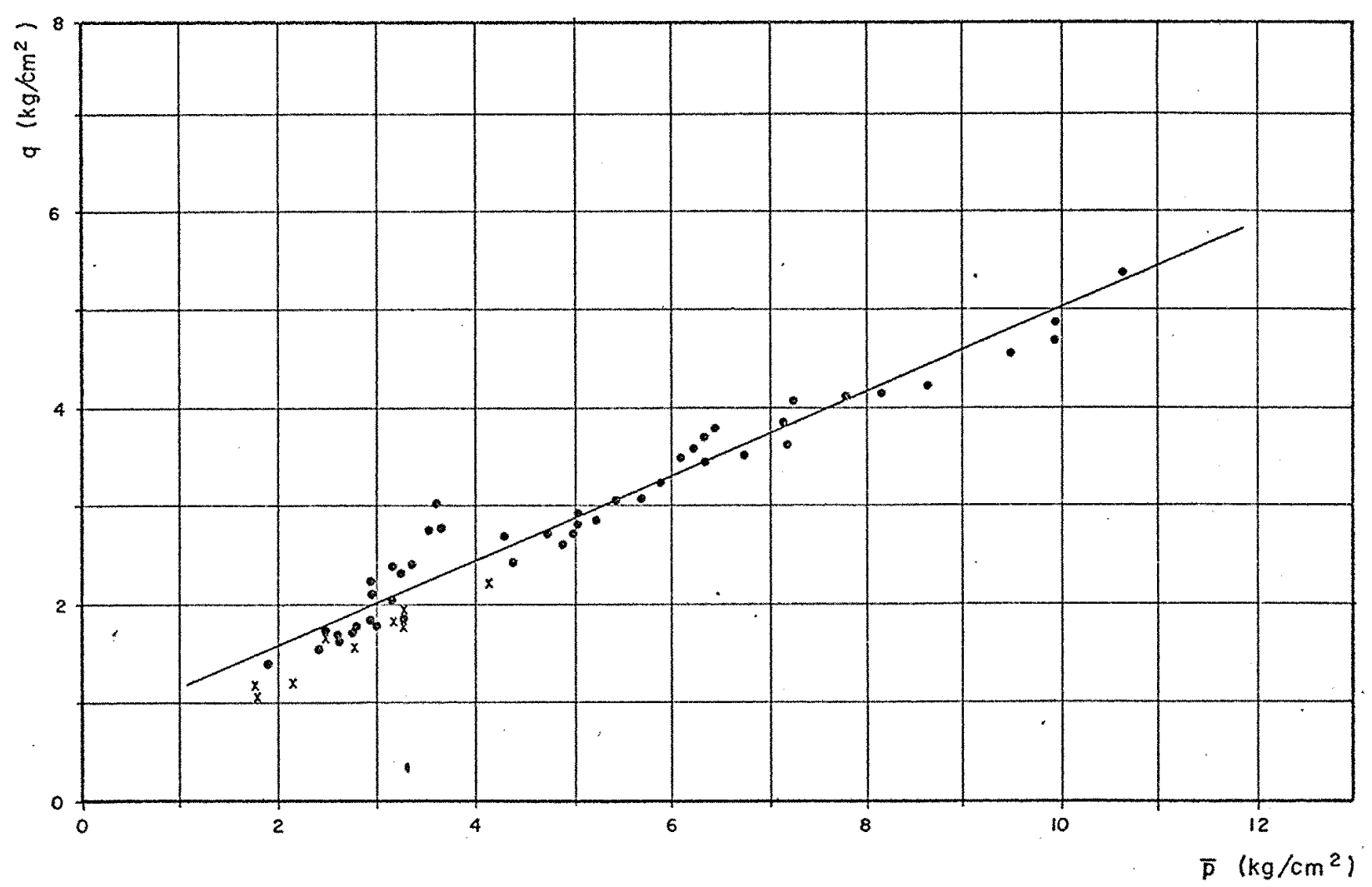

\begin{tabular}{|c|c|c|c|c|}
\hline $\begin{array}{c}\text { REGRESS ÃO LINEAR } \\
q, \bar{p} e \mathrm{~m} \mathrm{~kg} / \mathrm{cm}^{2}\end{array}$ & $N$ & $r$ & $\begin{array}{c}\text { COESAOO } \\
\text { EFETIVA } \\
\left(c^{\prime}\right) \\
\mathrm{kg} / \mathrm{cm}^{2}\end{array}$ & $\begin{array}{c}\text { ANGULO DE } \\
\text { ATRITO EFETNO } \\
\left(\varphi^{\prime}\right)\end{array}$ \\
\hline$q=0,74+\bar{p} \cdot \operatorname{tg} 23,3^{\circ}$ & 48 & 0,97 & 0,82 & $25,5^{\circ}$ \\
\hline
\end{tabular}

NOTAS:

1 - Os valores de $q$ e $\bar{p}$ apresentados são os correspondentes 'a ruptura pelo critério de $\left(\sigma_{1}-\sigma_{3}\right)$ máximo.

2 - Na regressão linear foram considerados somente os valores de q e $\bar{p}$ obtidos nos ensaios dos blocos indeformados.

CONVENÇÕES :

$\mathrm{N}=$ Número de ensaios

$r$ = Coeficiente de correlagão

$q=\frac{\sigma_{1}-\sigma_{3}}{2}$

$\bar{p}=\frac{\bar{\sigma}_{1}+\bar{\sigma}_{3}}{2}$

LEGENDA:

- Amostras dos blocos indeformados do macigo.

- Amostras moldadas estaticamento no laboratório (Relatório $5-09 / 79$ ).

\begin{tabular}{|c|c|}
\hline \multicolumn{2}{|c|}{ ITAIPU BINACIONAL } \\
\hline $\begin{array}{r}\text { BARRAGEM DE TERRA E D } \\
\text { MACICO DE ARGIL } \\
\text { REGRESSÃOO LINEA }\end{array}$ & $\begin{array}{l}\text { E TRANSICÃO-M.E. } \\
\text { A PLASTICA } \\
\text { AR } q \times \bar{p}\end{array}$ \\
\hline DIRETORIA TÉCNICA - SO.T. & ESCALA: \\
\hline 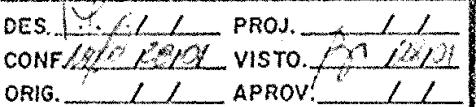 & $\begin{array}{l}\text { RELATÓRIO: } \frac{S 01 / 82}{16} \\
\text { ANEXO: } \frac{16}{}\end{array}$ \\
\hline
\end{tabular}


ENSAIO TRIAXIAL $\bar{R}$

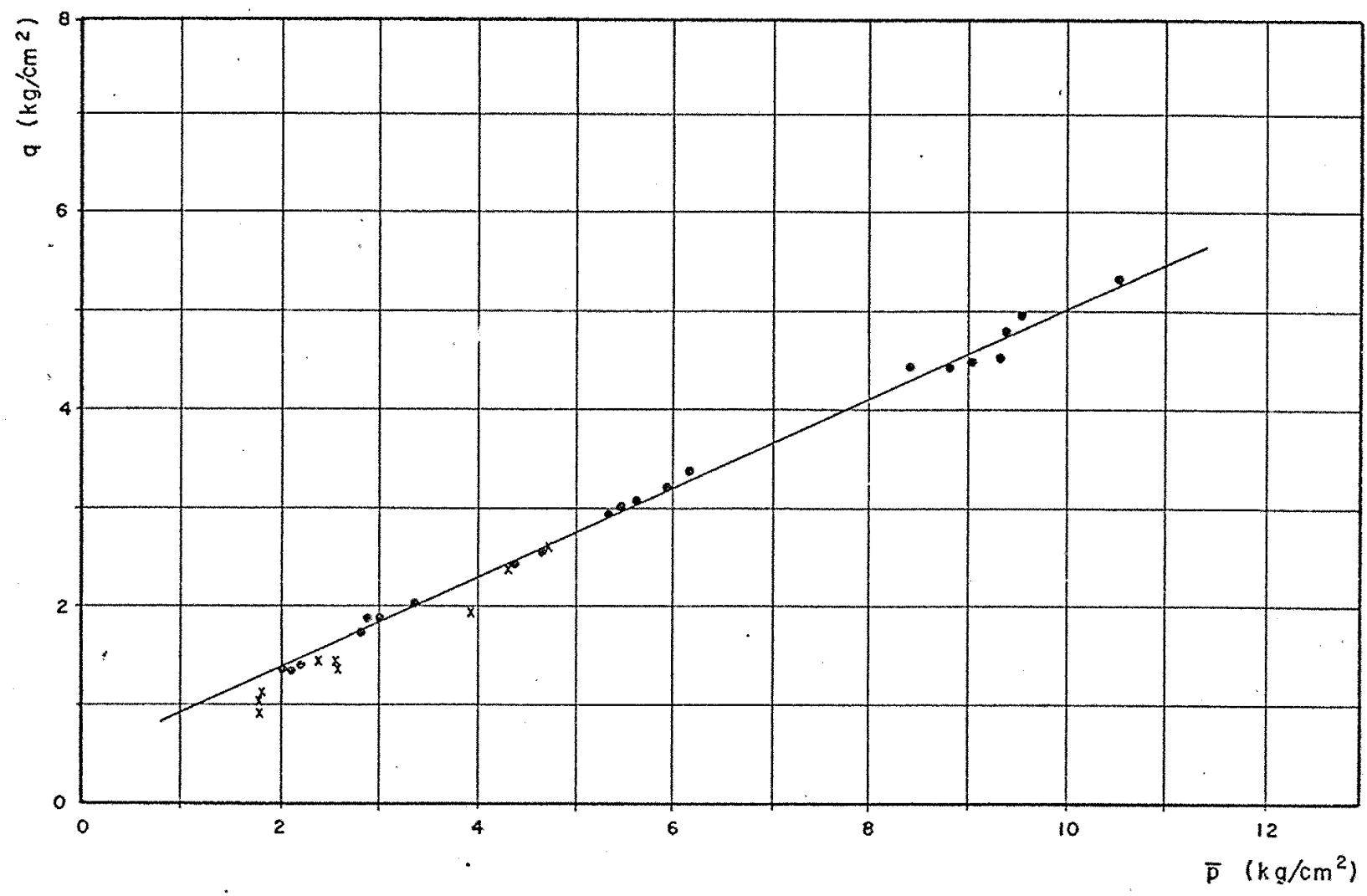

\begin{tabular}{|c|c|c|c|c|}
\hline $\begin{array}{c}\text { REGRESS } \bar{A} O \text { LINEAR } \\
q, \bar{p} \mathrm{e} m \mathrm{~kg} / \mathrm{cm}^{2}\end{array}$ & $N$ & $r$ & $\begin{array}{c}\text { COESĂO } \\
\text { EFETIVA } \\
\left(\mathrm{c}^{\prime}\right) \\
\mathrm{kg} / \mathrm{cm}^{2}\end{array}$ & $\begin{array}{c}\text { ANGULO DE } \\
\text { ATRIO EFETIVO } \\
\left(\varphi^{\prime}\right)\end{array}$ \\
\hline$q=0,46+\bar{p} \cdot 1 \mathrm{~g} 24,7^{\circ}$ & 21 & 0,99 & 0,52 & $27,4^{\circ}$ \\
\hline
\end{tabular}

NOTAS:

1 - Os valores de $q$ e $\bar{p}$ apresentados são os correspondentes 'a ruptura pelo critério de $\left(\sigma_{1}-\sigma_{3}\right)$ máximo.

2. - Na regressão linear foram considerados somente os valores de $q$ e $p$ obtidos nos ensaios dos blocos indeformados.

CONVEŅ̧ÕES:

$N=$ Número de ensaios

$r=$ Coeficiente de correlação

$q=\frac{\sigma_{1}-\sigma_{3}}{2}$

$\bar{p}=\frac{\bar{\sigma}_{1}+\bar{\sigma}_{3}}{2}$

LEGENDA:

- Amostras dos blocos indeformados do ríacico.

* - Amostras moldadas estaticamente no laboratório (Relatório $5-09 / 79$ ).

\begin{tabular}{|c|c|}
\hline ITAIPU & IMAOIOBUA \\
\hline $\begin{array}{r}\text { BARRAGEM DE TERRA E D } \\
\text { MACICOO DE ARGIL } \\
\text { REGRESSÃO LINEA }\end{array}$ & $\begin{array}{l}\text { E TRANSISÄO - M.E. } \\
A \text { PLASTICA } \\
R \quad q \times \bar{p}\end{array}$ \\
\hline DIRETORIA TÉCNICA - SO.T. & ESCALA: \\
\hline 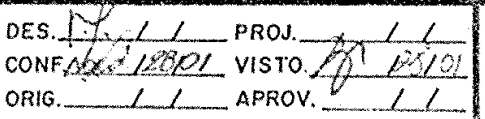 & $\begin{array}{lc}\text { RELATORIO: } & S 01 / 82 \\
\text { ANEXO: } & 17\end{array}$ \\
\hline
\end{tabular}


ENSAIO TRIAXIAL $\bar{R}$ Sot

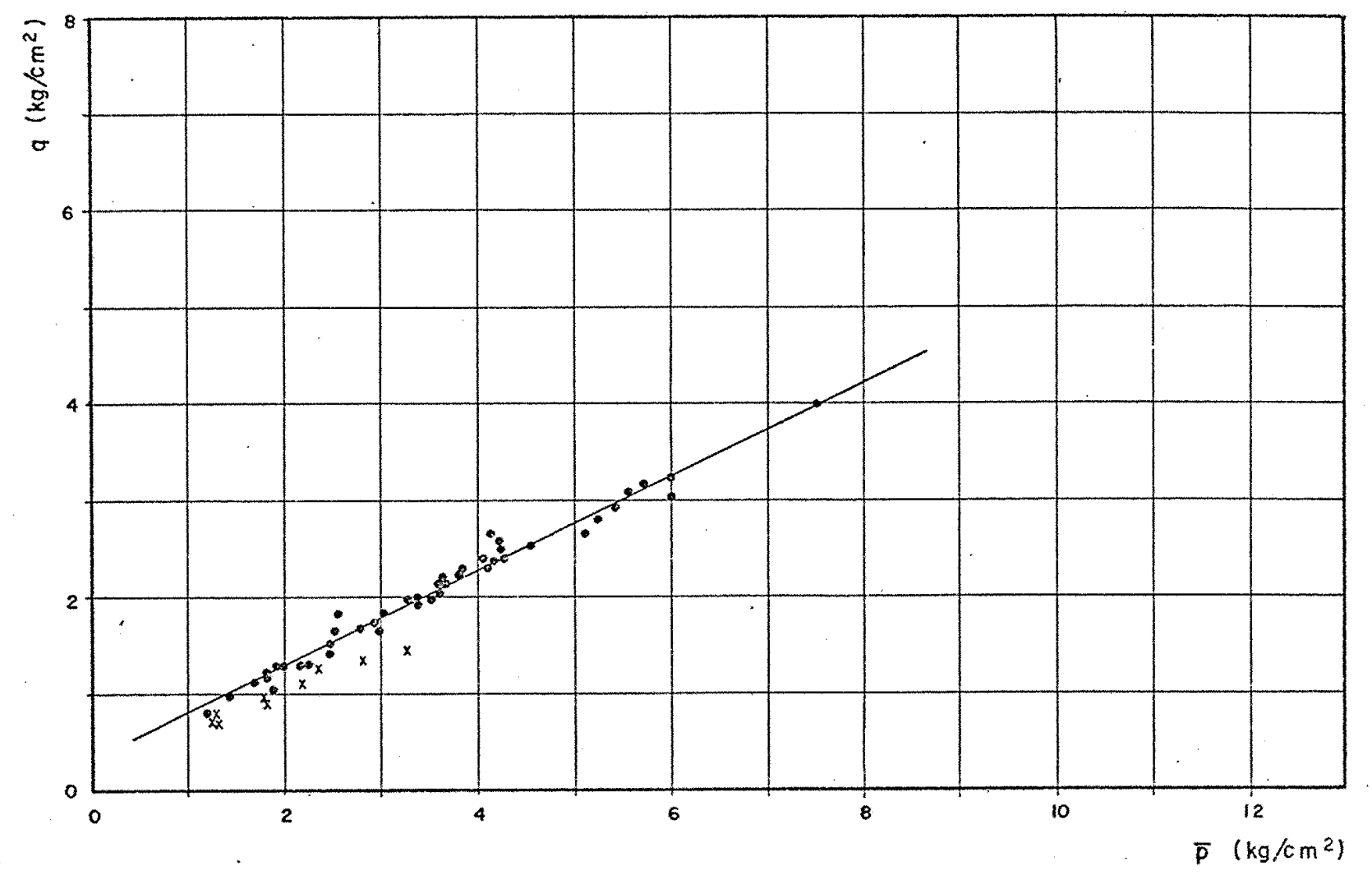

\begin{tabular}{|c|c|c|c|c|}
\hline $\begin{array}{c}\text { REGRESSÃO LINEAR } \\
q, \bar{p} \mathrm{em} \mathrm{kg} / \mathrm{cm}^{2}\end{array}$ & $\mathrm{~N}$ & $\begin{array}{c}\text { COESÄO } \\
\text { EFETIVA } \\
\left(\mathrm{c}^{\prime}\right) \\
\mathrm{kg} / \mathrm{cm}^{2}\end{array}$ & $\begin{array}{c}\text { ANGULO DE } \\
\left(\varphi^{\prime}\right)\end{array}$ \\
\hline$q=0,31+\bar{p} \cdot \mathrm{tg} 26,1^{\circ}$ & 45 & 0,99 & 0,36 & $29,3^{\circ}$ \\
\hline
\end{tabular}

NOTAS:

1 - Os valores de $q$ e $\bar{p}$ apresentados são os correspondentes 'o ruptura pelo critério de $\left(\sigma_{1}-\sigma_{3}\right)$ máximo.

2 - Na regressäo linear foram considerados somente os valores de $q$ e $\bar{p}$ obtidos nos ensaios dos blocos indeformados.

CONVENCÕES:

$N=$ Número de ensoios

$r$ = Coeficiente de correlação

$q=\frac{\sigma_{1}-\sigma_{3}}{2}$

$\bar{p}=\frac{\bar{\sigma}_{1}+\bar{\sigma}_{3}}{2}$

LEGENDA:

- Amostras dos blocos indeformados do macico.

$x$ - Amostras moldados estaticamente no laboratório (Relatório $S-09 / 79$ ).

\begin{tabular}{|c|c|}
\hline \multicolumn{2}{|c|}{ ITAIPU BINACIONAL } \\
\hline $\begin{array}{r}\text { BARRAGEM DE TERRA E D } \\
\text { MACIÇO DE ARGILA } \\
\text { REGRESSÃO LINEA }\end{array}$ & $\begin{array}{l}\text { E TRANSICÃO- M.E. } \\
\text { PLASTICA } \\
R \quad q \times \bar{p}\end{array}$ \\
\hline DIRETORIA TÉCNICA-SO.T: & ESCALA: \\
\hline 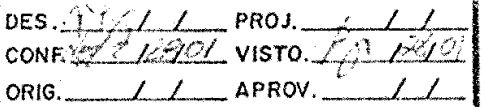 & $\begin{array}{l}\text { RELATÓRIO: } S 01 / 8 \\
\text { ANEXO: } \quad 18\end{array}$ \\
\hline
\end{tabular}




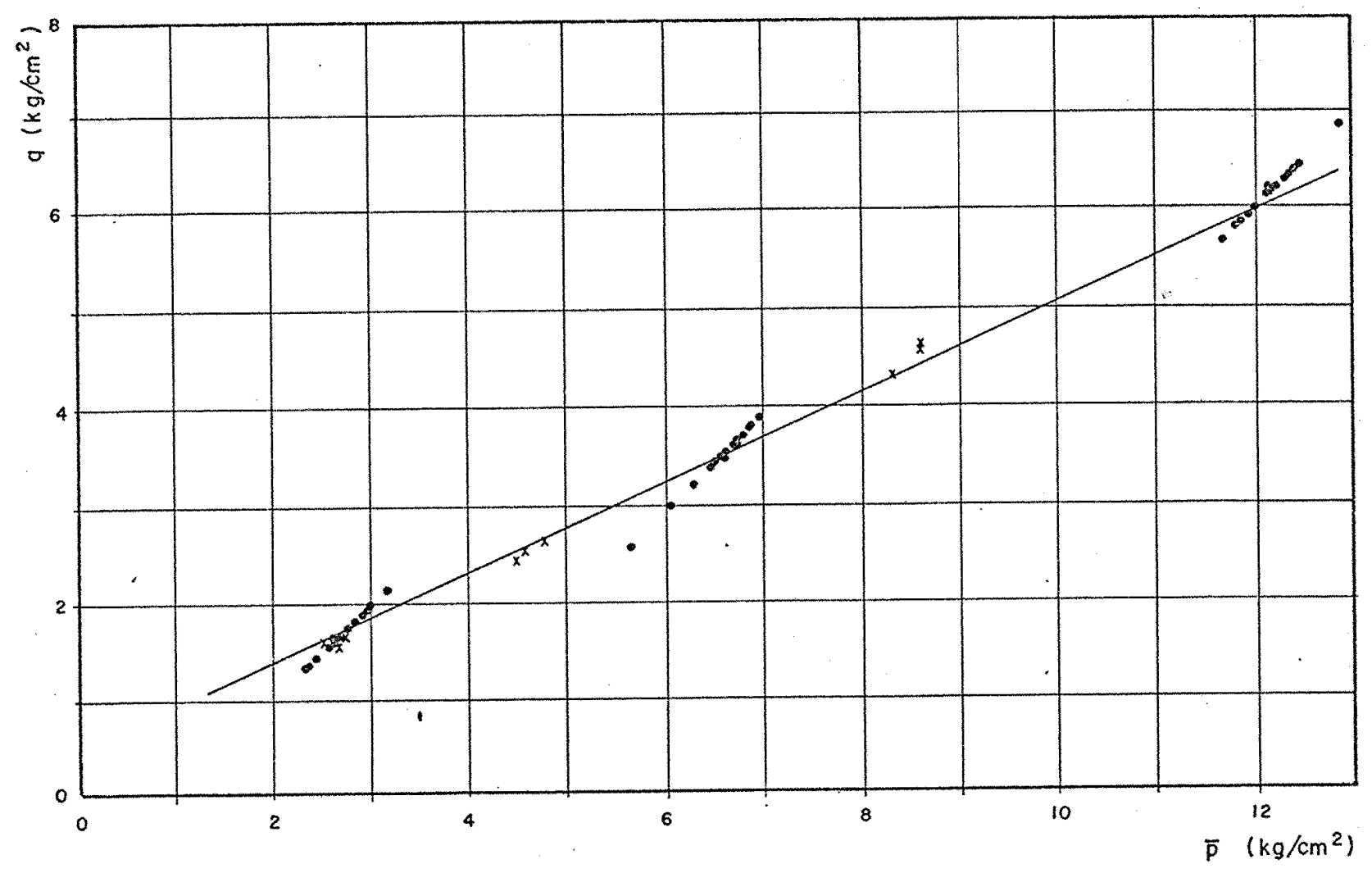

\begin{tabular}{|c|c|c|c|c|}
\hline $\begin{array}{c}\text { REGRESSÃO LINEAR } \\
q, \bar{p} \text { em } \mathrm{kg} / \mathrm{cm}^{2}\end{array}$ & $N$ & $r$ & $\begin{array}{c}\text { COESÃO } \\
\text { EFETIVA ATGULO UEE } \\
\left(c^{\prime}\right) \\
\mathrm{kg} / \mathrm{cm}^{2}\end{array}$ & $\begin{array}{c}\text { ATRITO EFETIVO } \\
\left(\varphi^{\prime}\right)\end{array}$ \\
\hline$q=0,48+\bar{p} \cdot t g 24,7^{\circ}$ & 49 & 0,99 & 0,54 & $27,4^{\circ}$ \\
\hline
\end{tabular}

NOTAS:

1 - Os valores de $q$ e $\bar{p}$ apresentados são os correspondentes 'a ruptura pelo critério de $\left(\sigma_{1}-\sigma_{3}\right)$ máximo.

2 - Na regressão linear foram considerados somente os valores de $q$ e $\bar{p}$ obtidos nos ensaios dos blocos indeformados.

3 - O ensaio lento nas amostras moldadas foi conduzido com saturação do corpo de prova por contra pressão.

CONVENCOES:

$N=$ Número de ensaios

$r$ = Coeficiente de correlação

$q=\frac{\sigma_{1}-\sigma_{3}}{2}$

$\bar{p}=\frac{\overline{\sigma_{1}}+\bar{\sigma}_{3}}{2}$

LEGENDA:

- Amostras dos blocos indeformados do maciço.

* - Amostras moldadas estaticomente no laboratório (Relatório $S-09 / 79$ ).

\begin{tabular}{|c|c|}
\hline ITAIPU & INNACIONAL \\
\hline $\begin{array}{r}\text { BARRAGEM DE TERRA E DE } \\
\text { MACICYO DE ARGIL } \\
\text { REGRESSÃO LINEA }\end{array}$ & $\begin{array}{l}\text { E. TRANSICẼOO-M.E. } \\
\text { A PLA'STICA } \\
\text { AR } q \times \overline{\mathrm{P}}\end{array}$ \\
\hline DIRETORIA TÉCNICA - SO.T. & ESCALA: \\
\hline 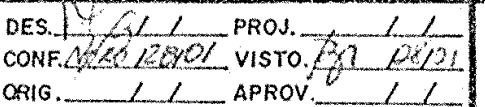 & $\begin{array}{l}\text { RELATÓRIO: } \frac{S O 1 / 82}{19} \\
\text { ANEXO: } \quad 19\end{array}$ \\
\hline
\end{tabular}


Anexo II - Resultados de ensaios de adensamento realizados com amostras do maciço compactado. 


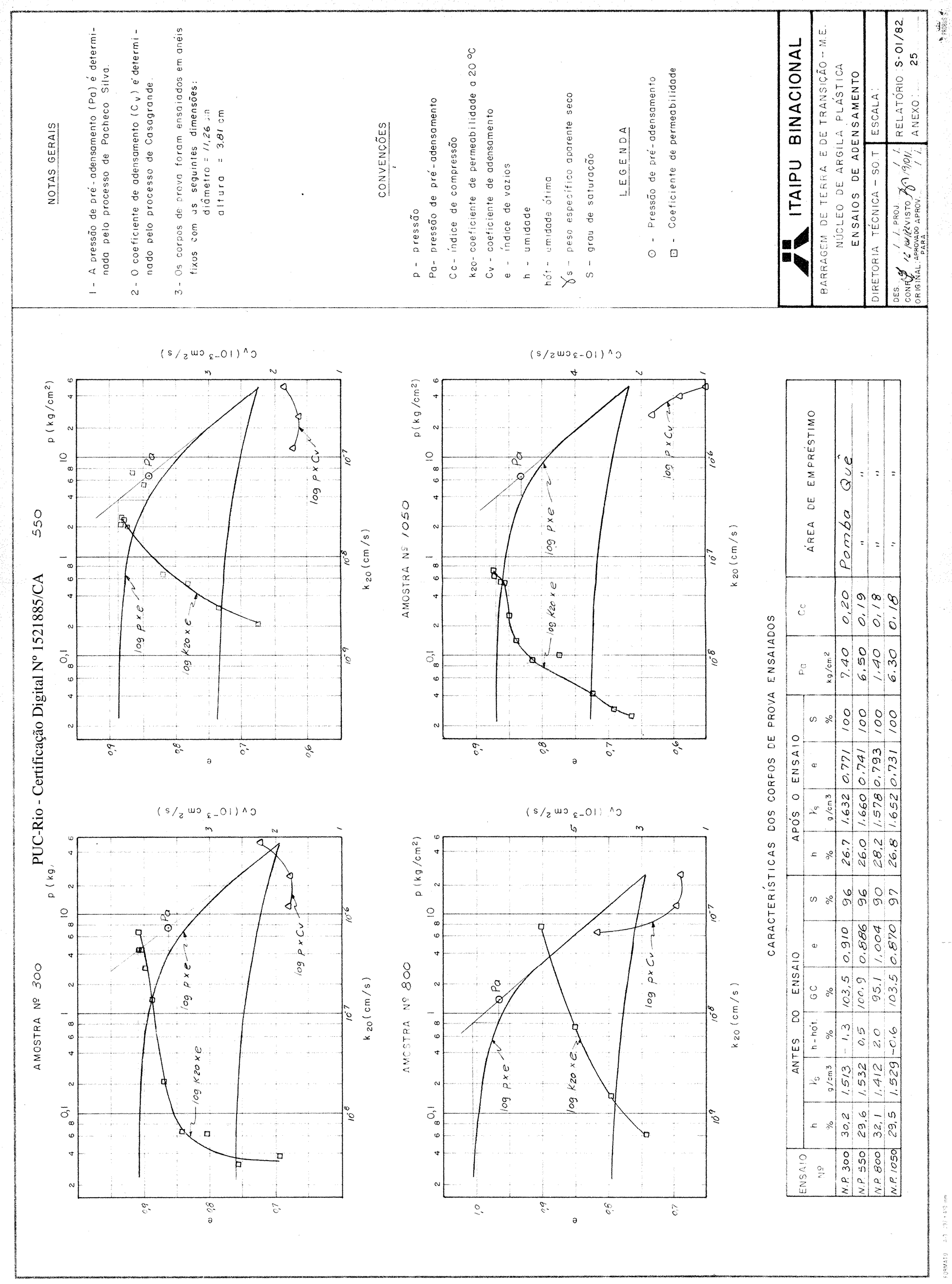



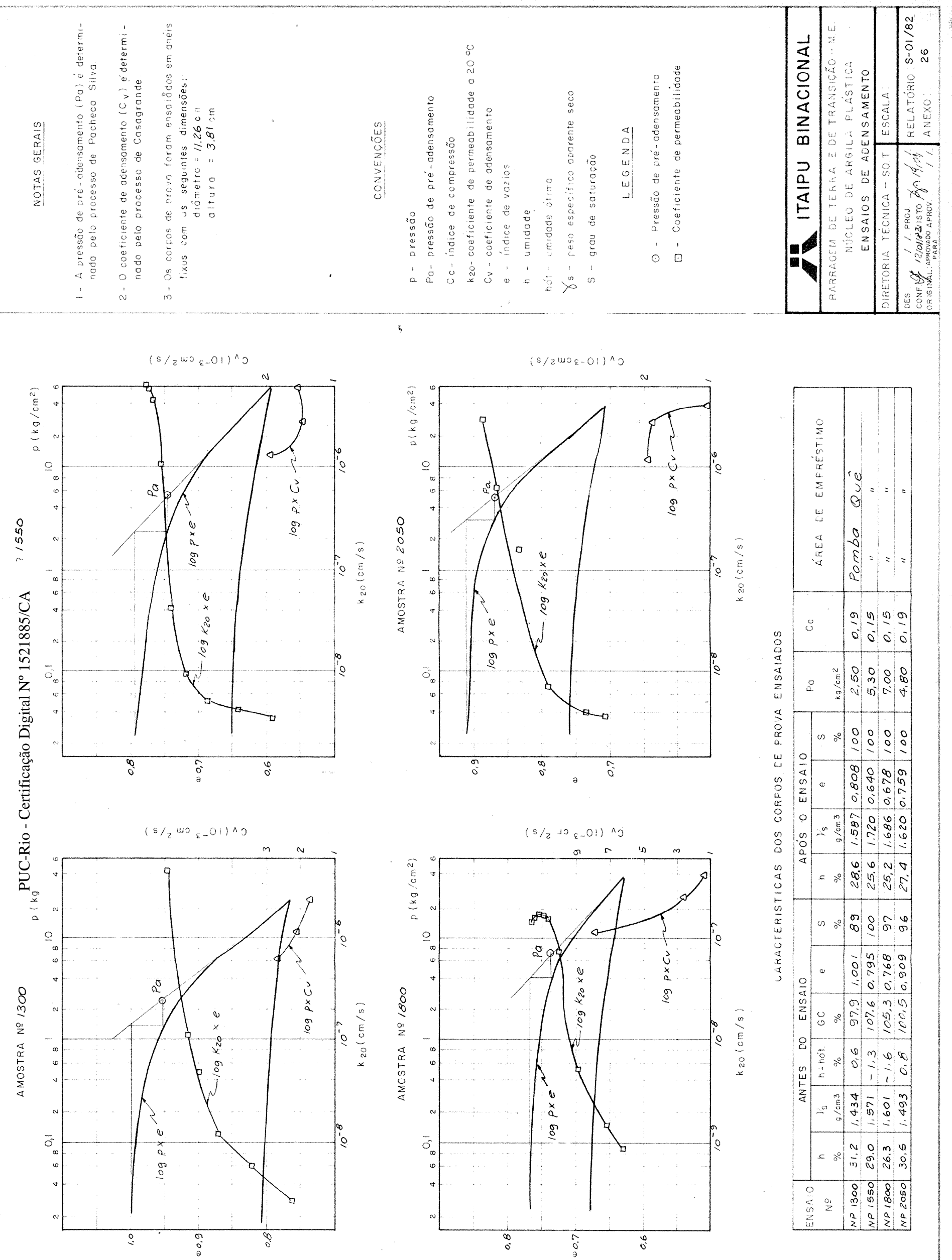

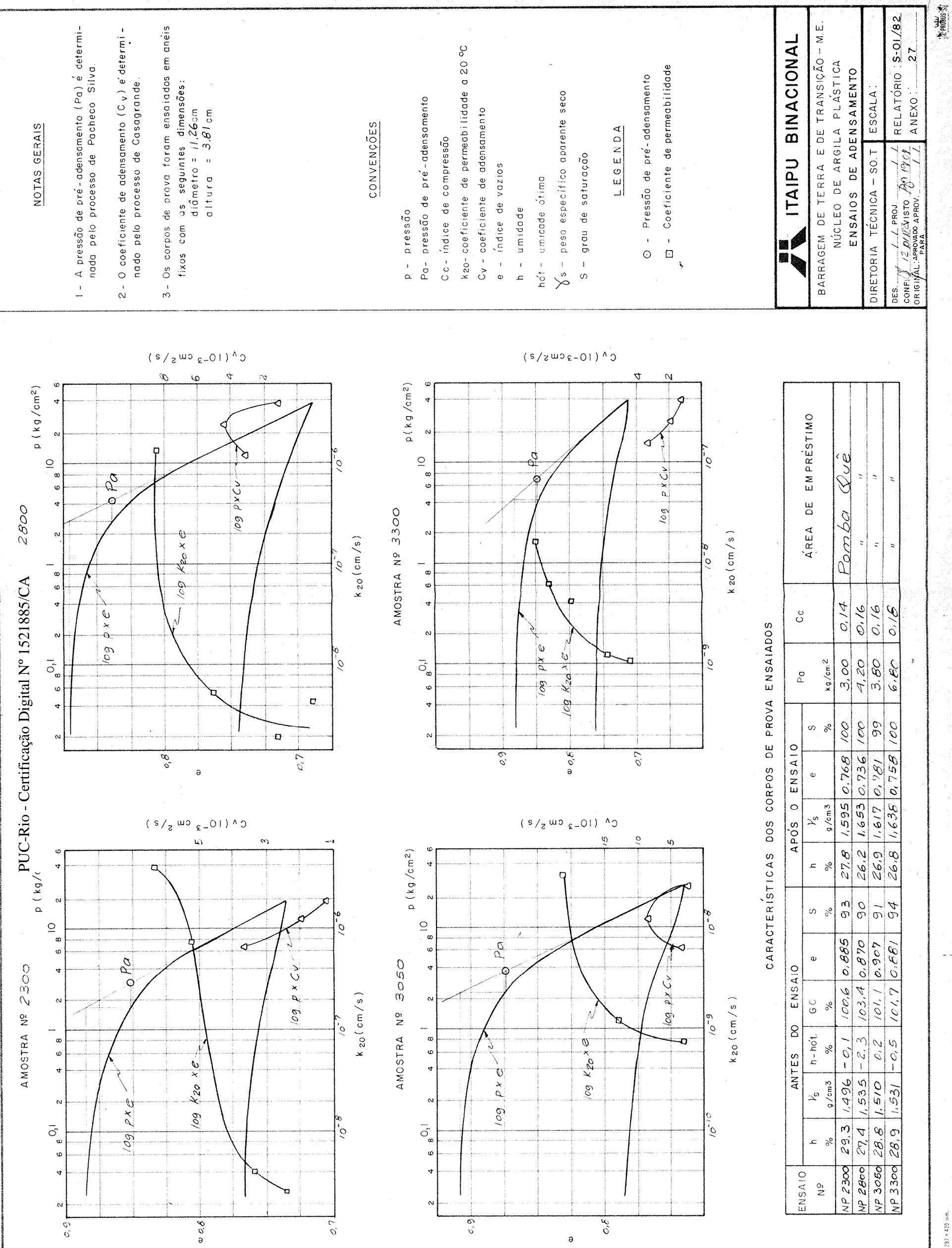

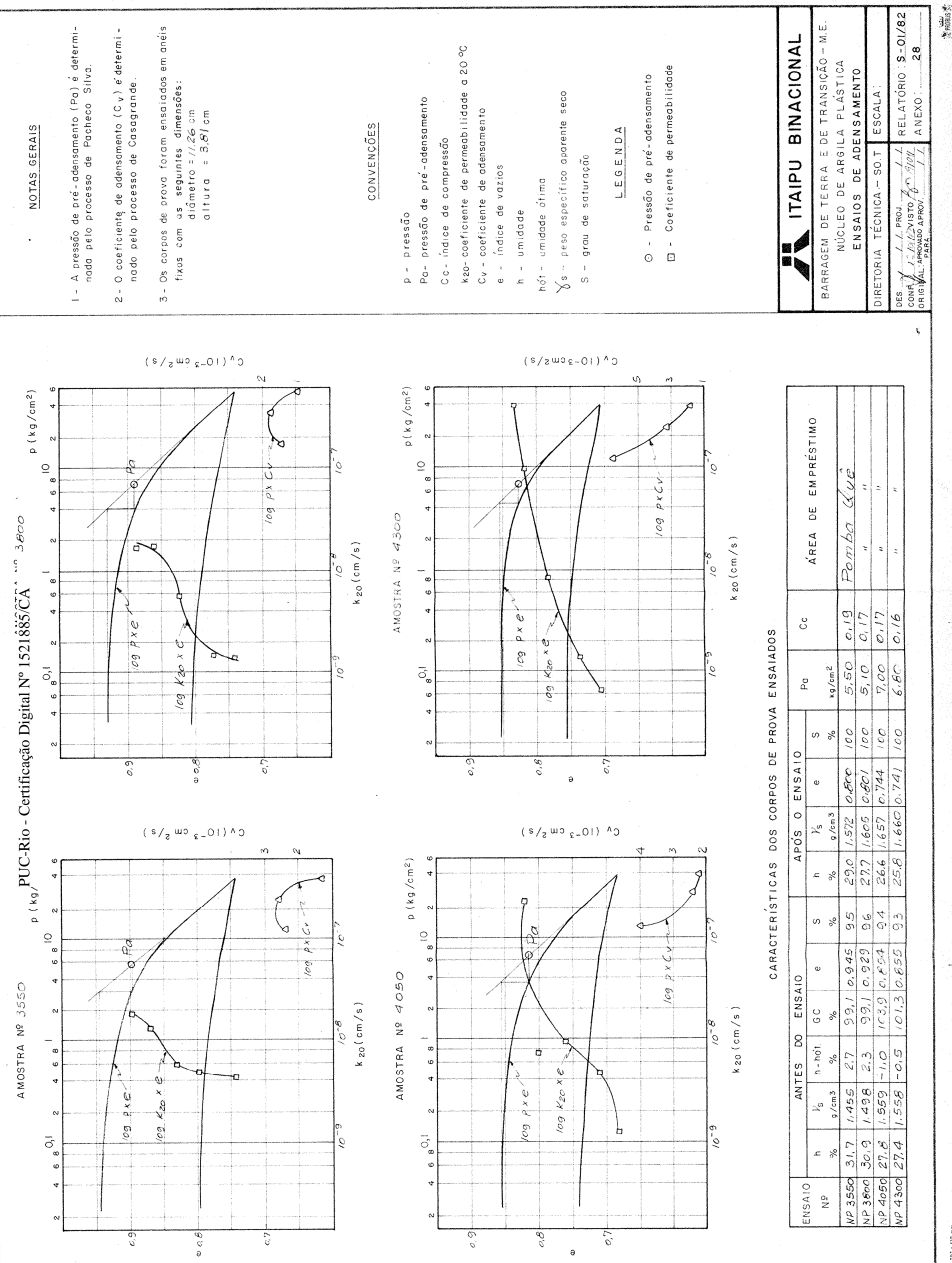

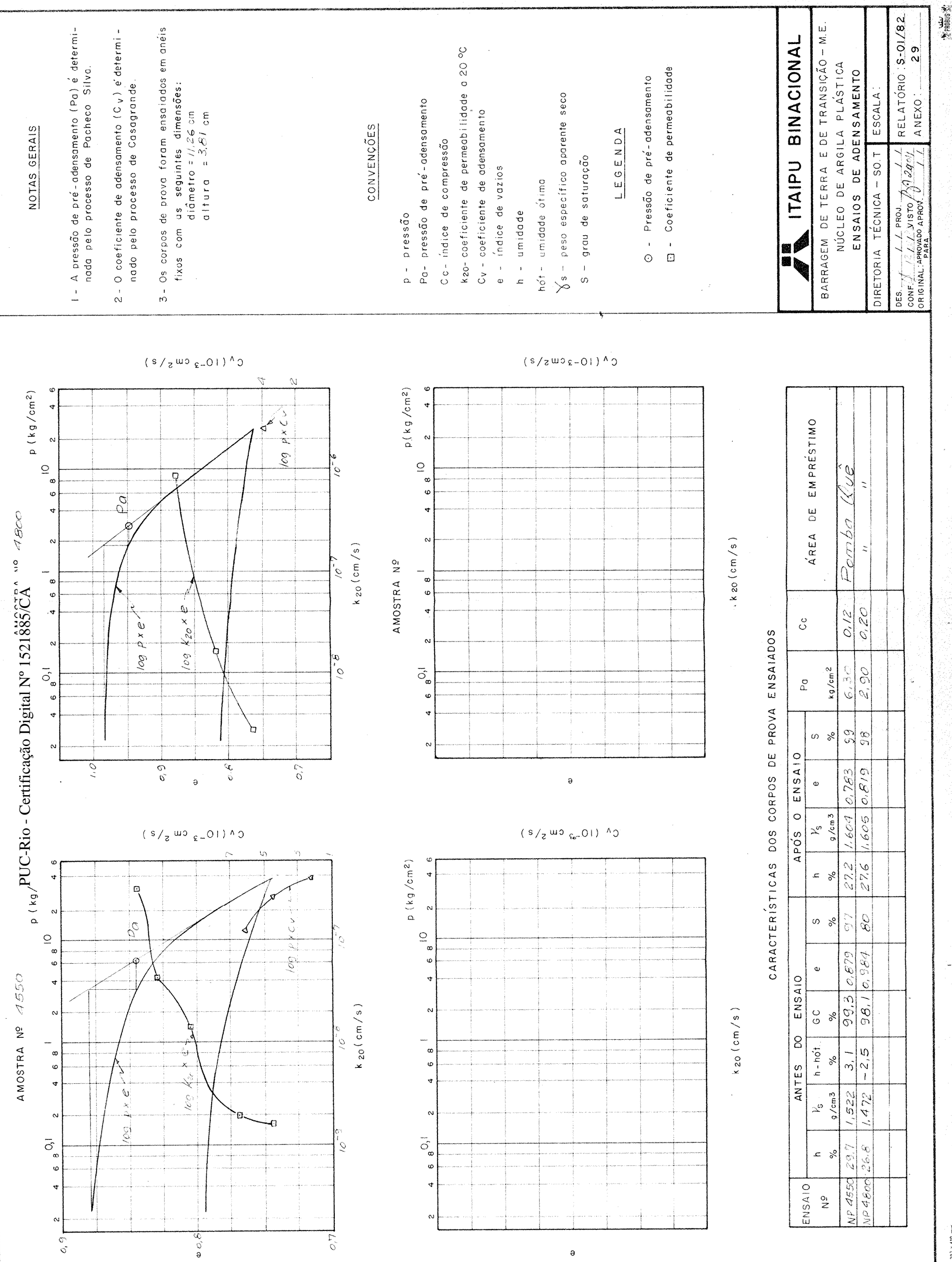
Anexo III - Planta da instrumentação da BTME. 


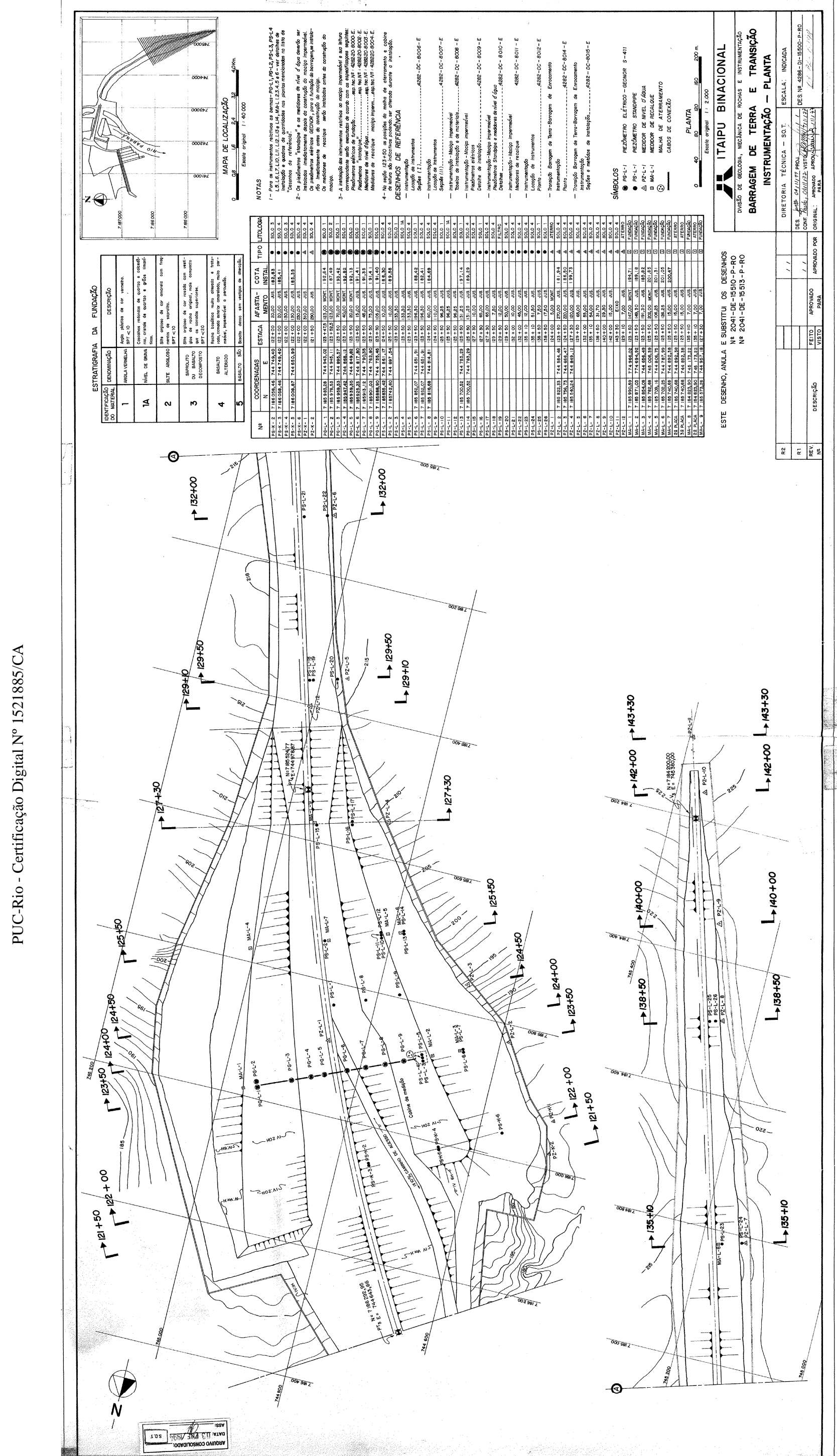


Anexo IV - Plantas do sistema de drenagem superficial da BTME. 


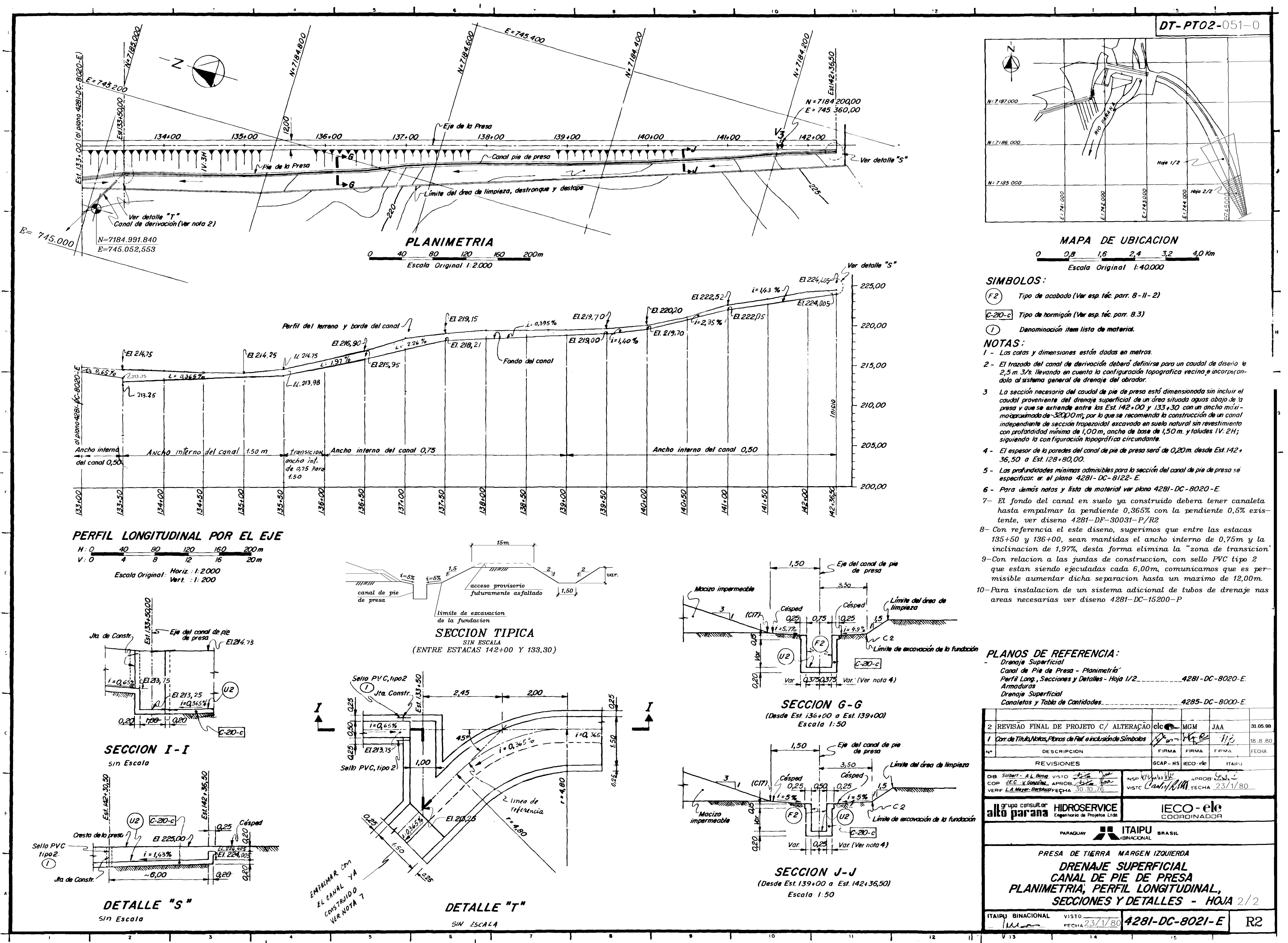




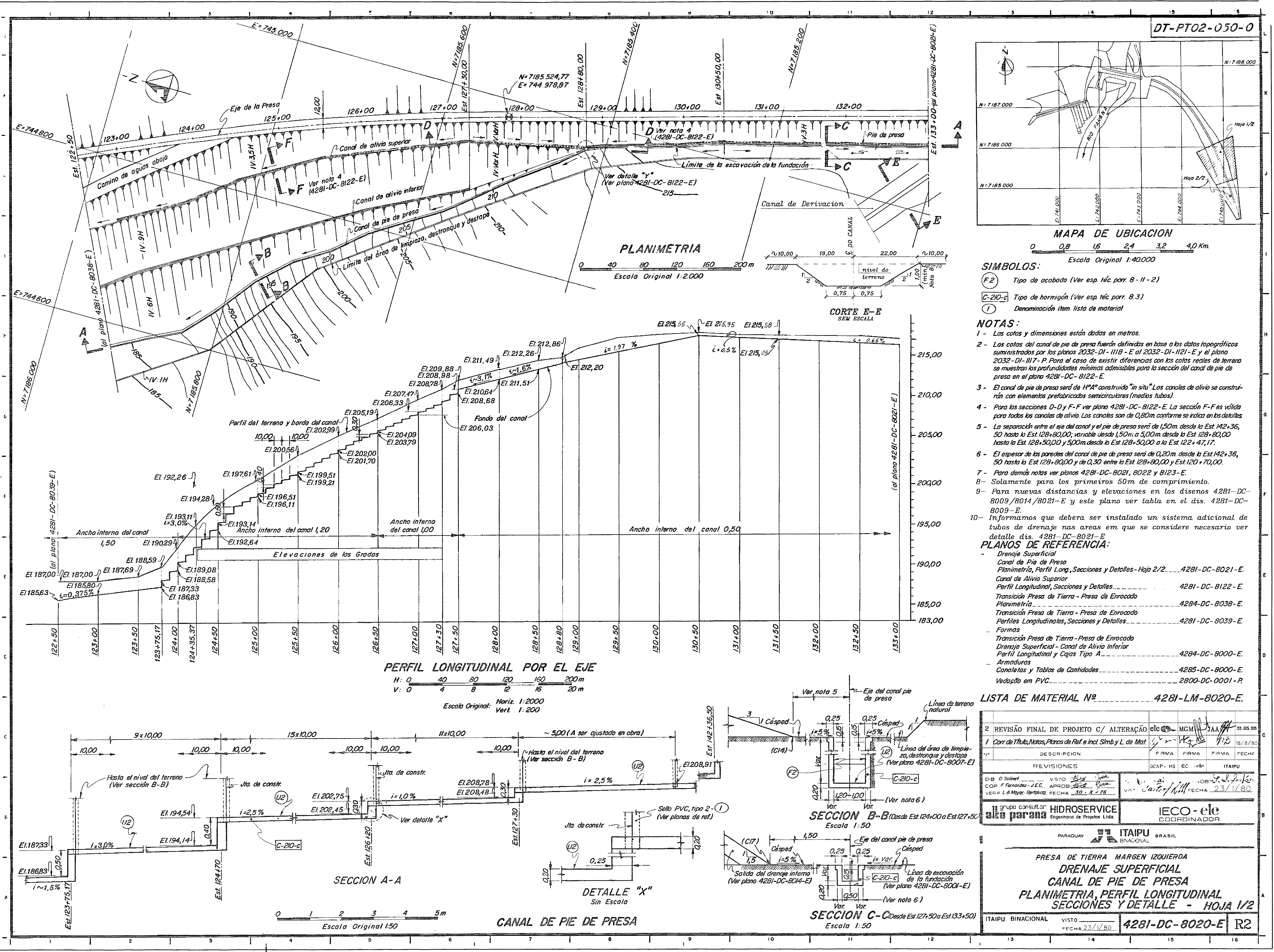


Anexo V - Localização dos marcos de referência na BTME. 


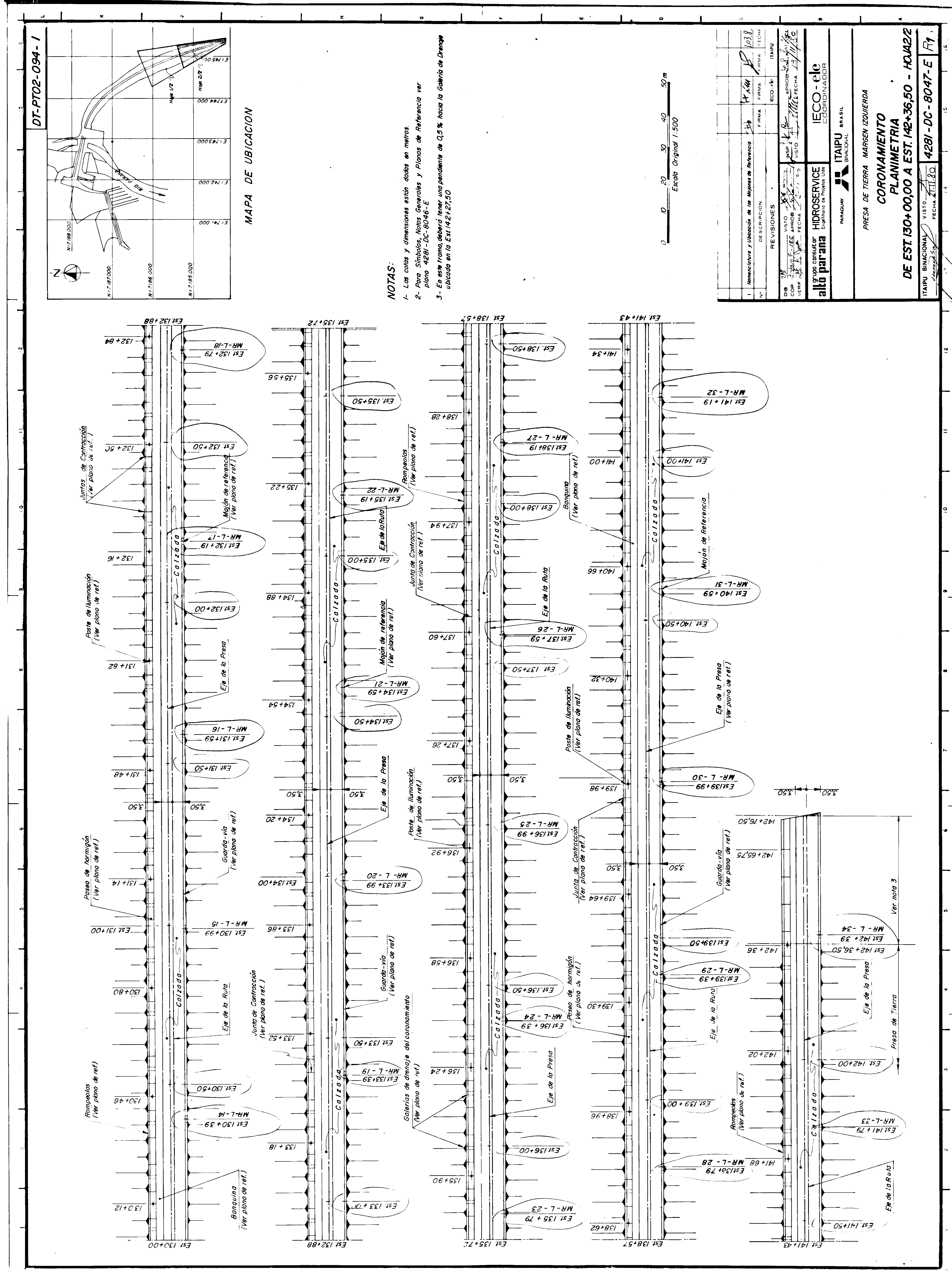




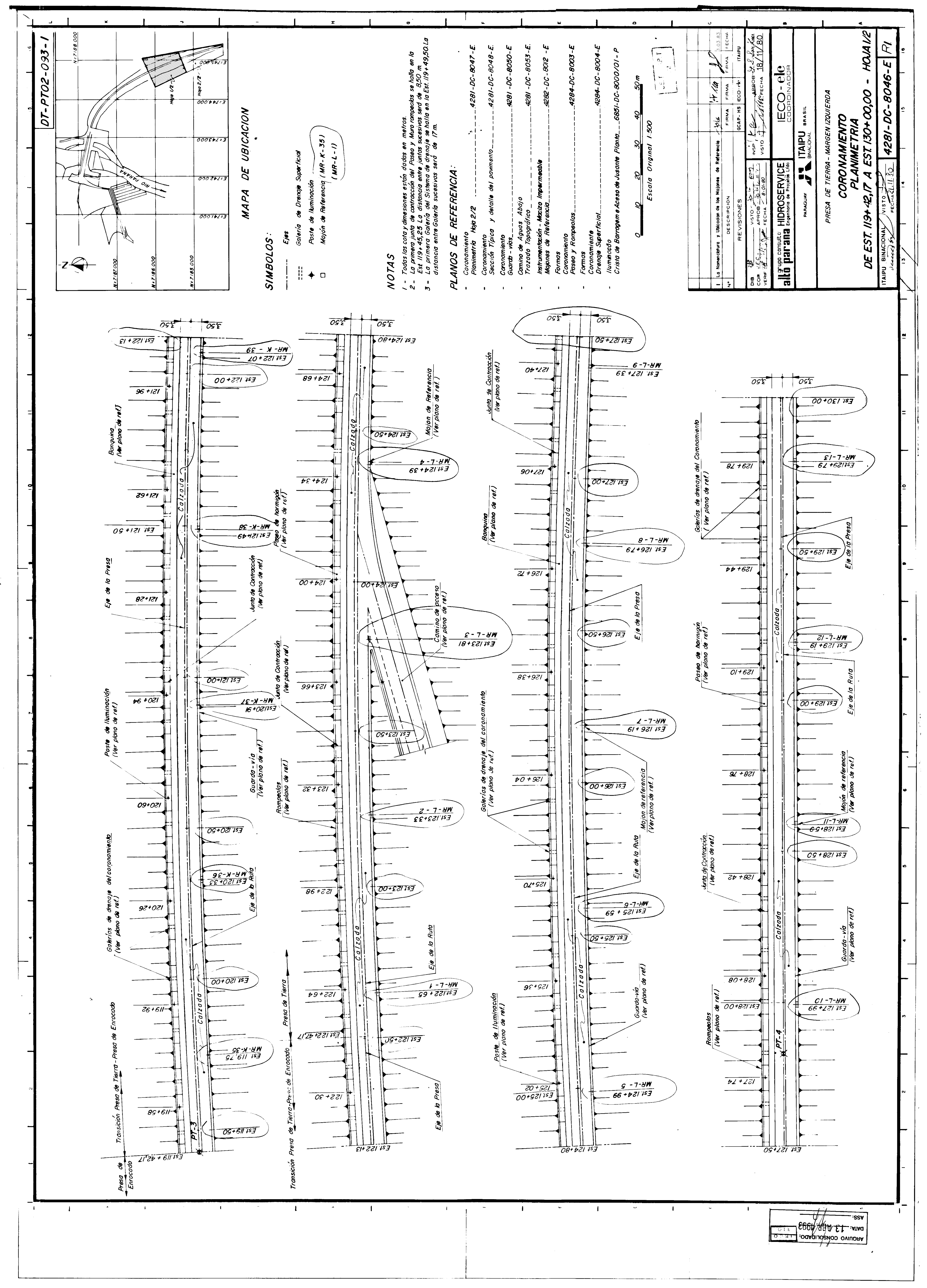


Anexo VI - Geometria das seções estudadas. 
$1 \quad{ }_{13}^{18}$

$15 \quad 1 \quad 16$

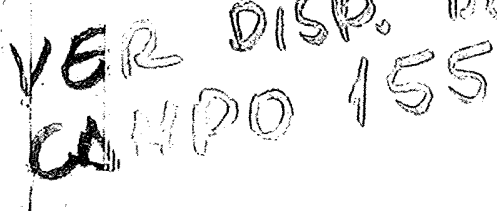

NA maxp probable El 223,00

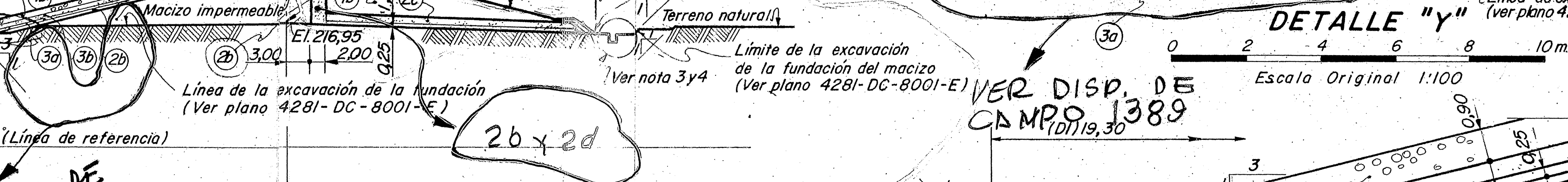
VER OISP GER DIPO 1550 SECCION EST. $130+00$

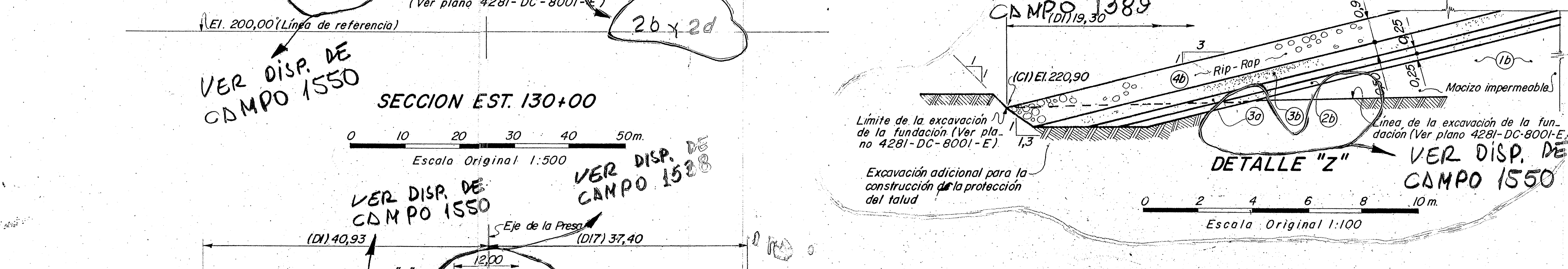

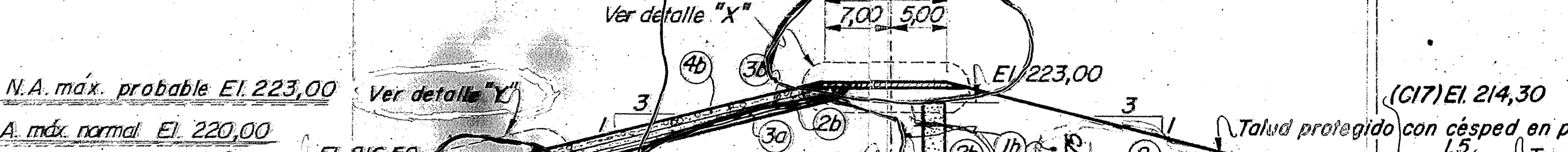

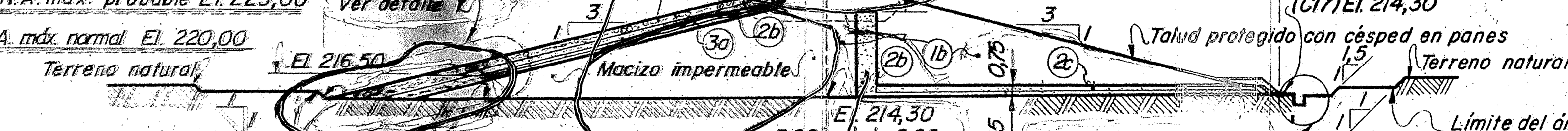

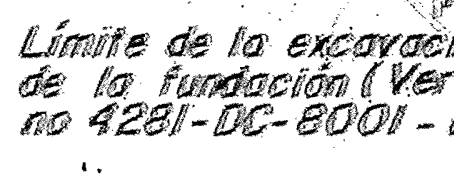

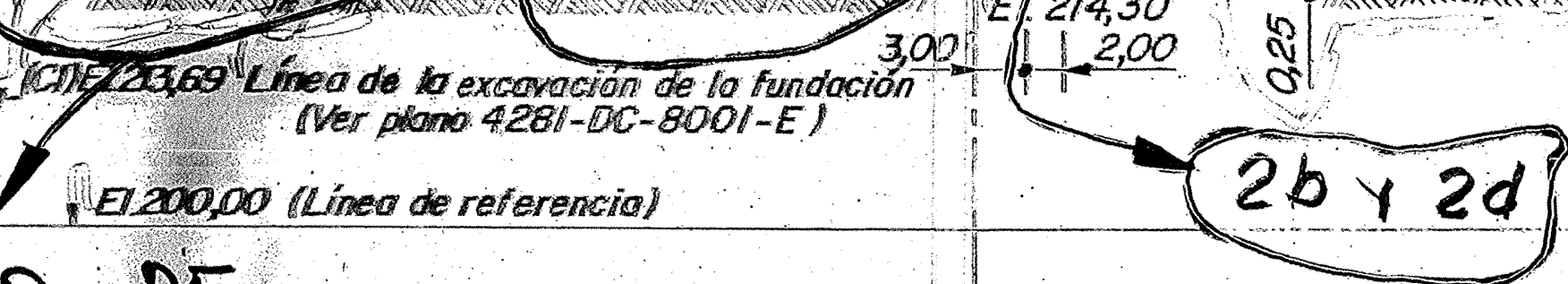

VER DISP, DE
CDNPO 1389
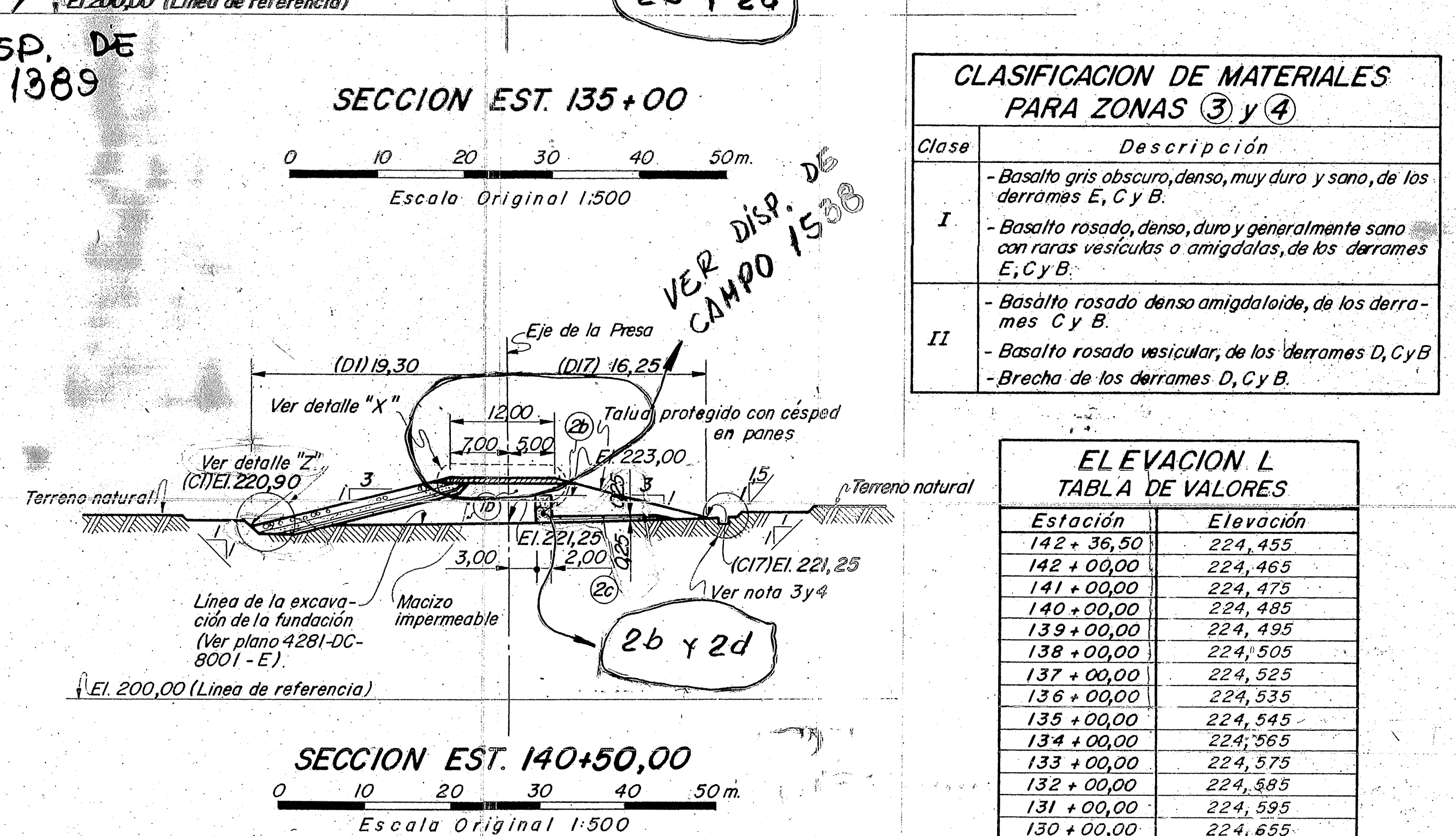

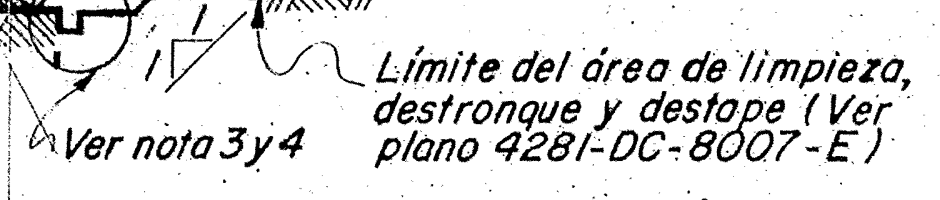

SIMBOLOS

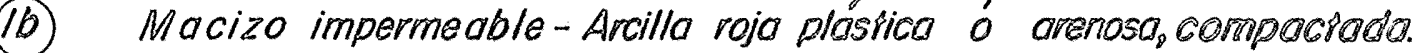

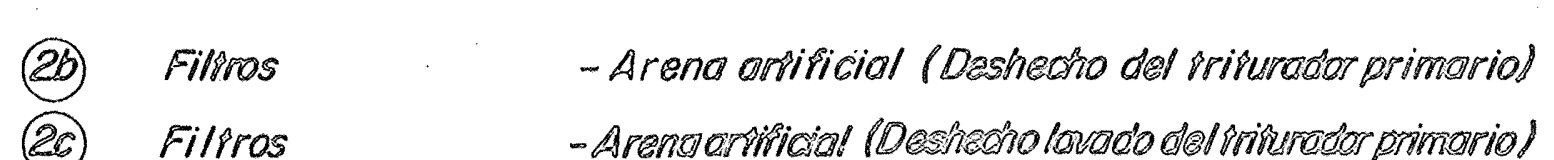

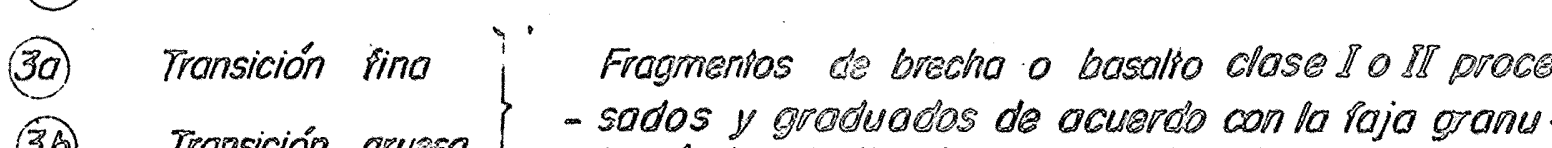

gresa 10 miririca

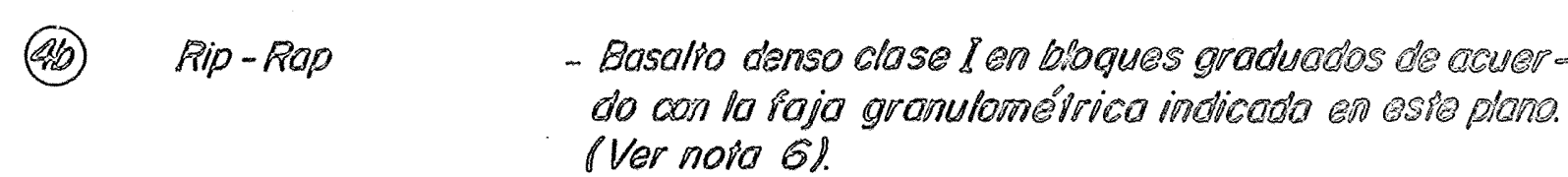

NOTAS

- Las coras
confrario.

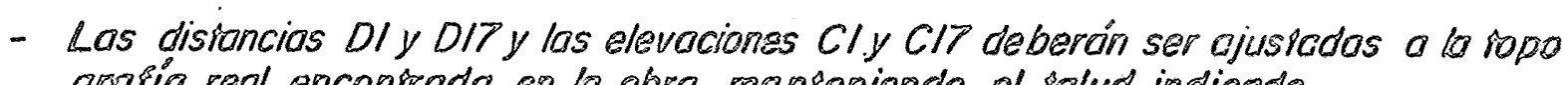

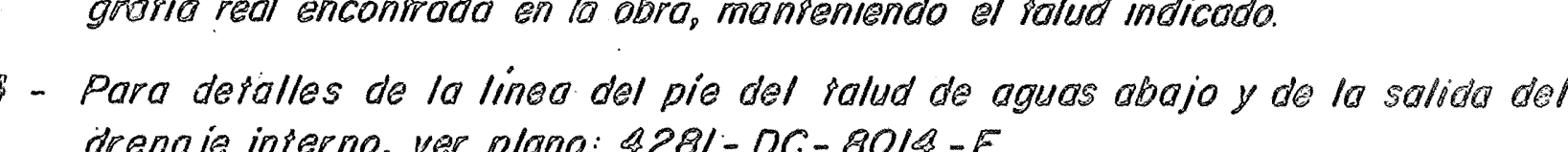

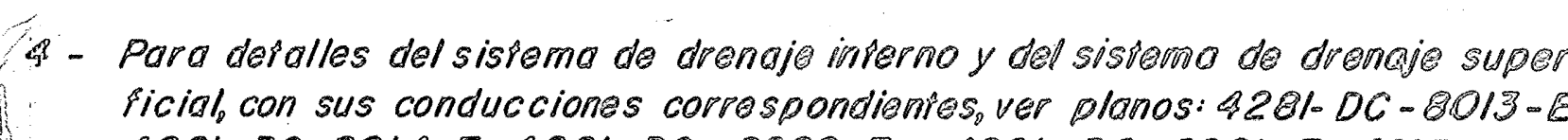

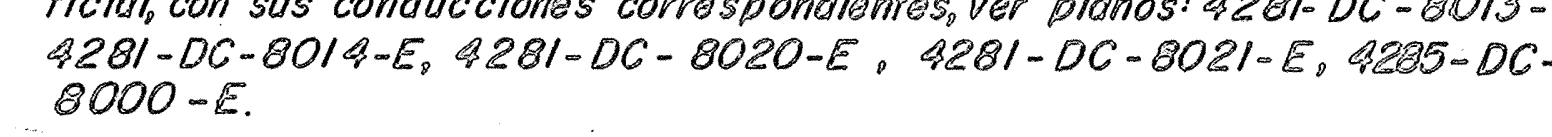

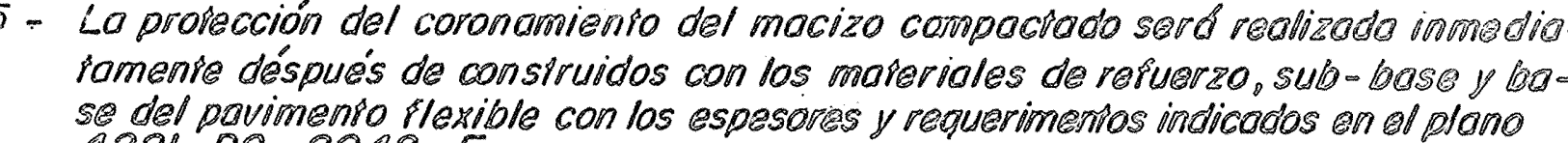

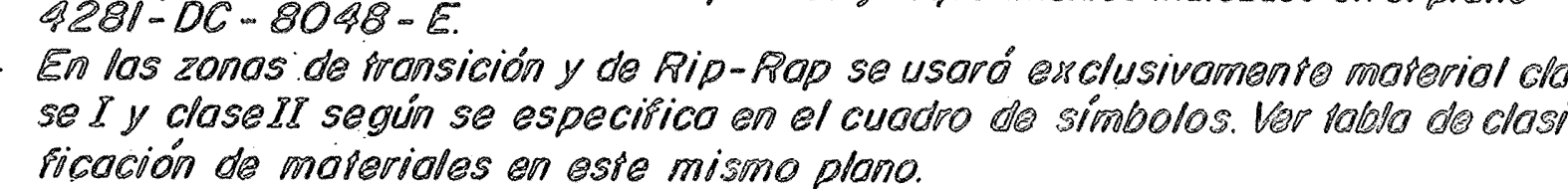

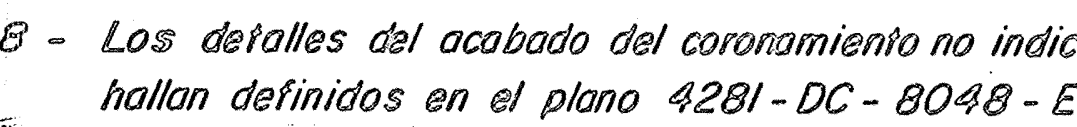

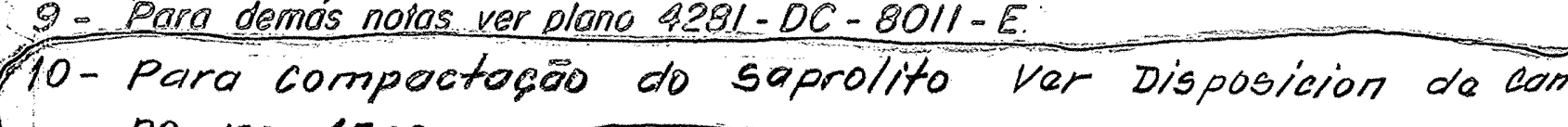
po 1701566

PLANOS DE REFERENGIA

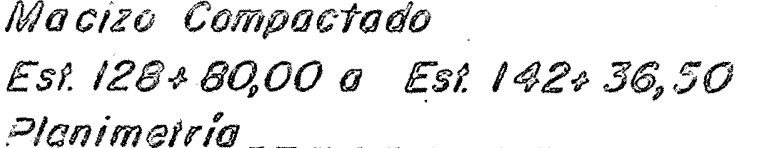

4281.05 .8011 .8

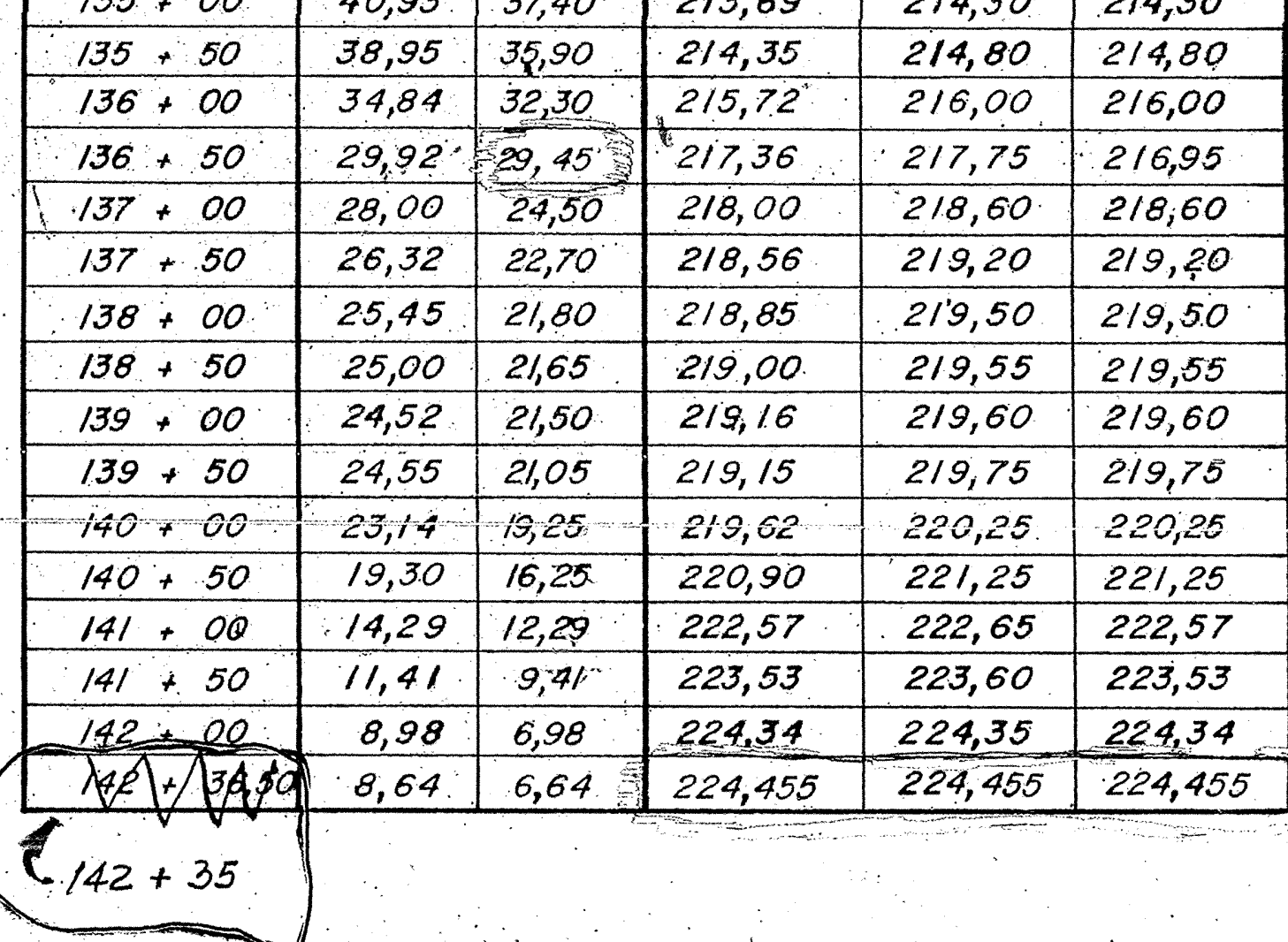

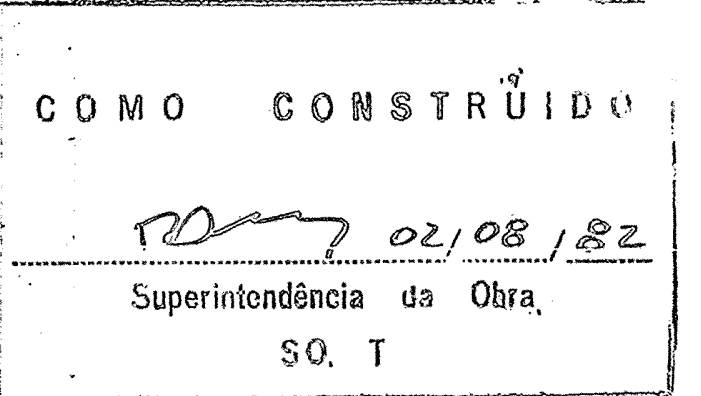

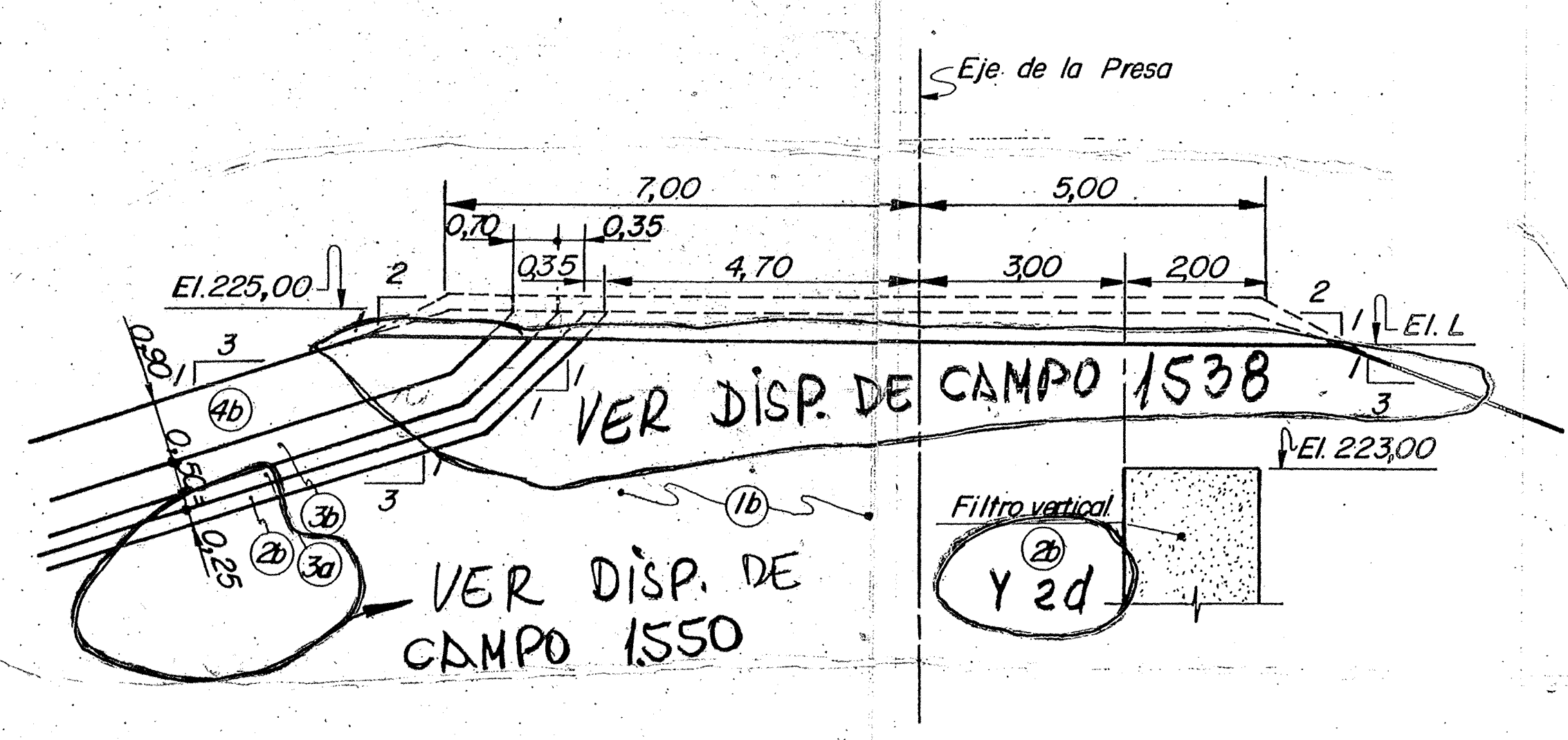
CAMPO 1.550

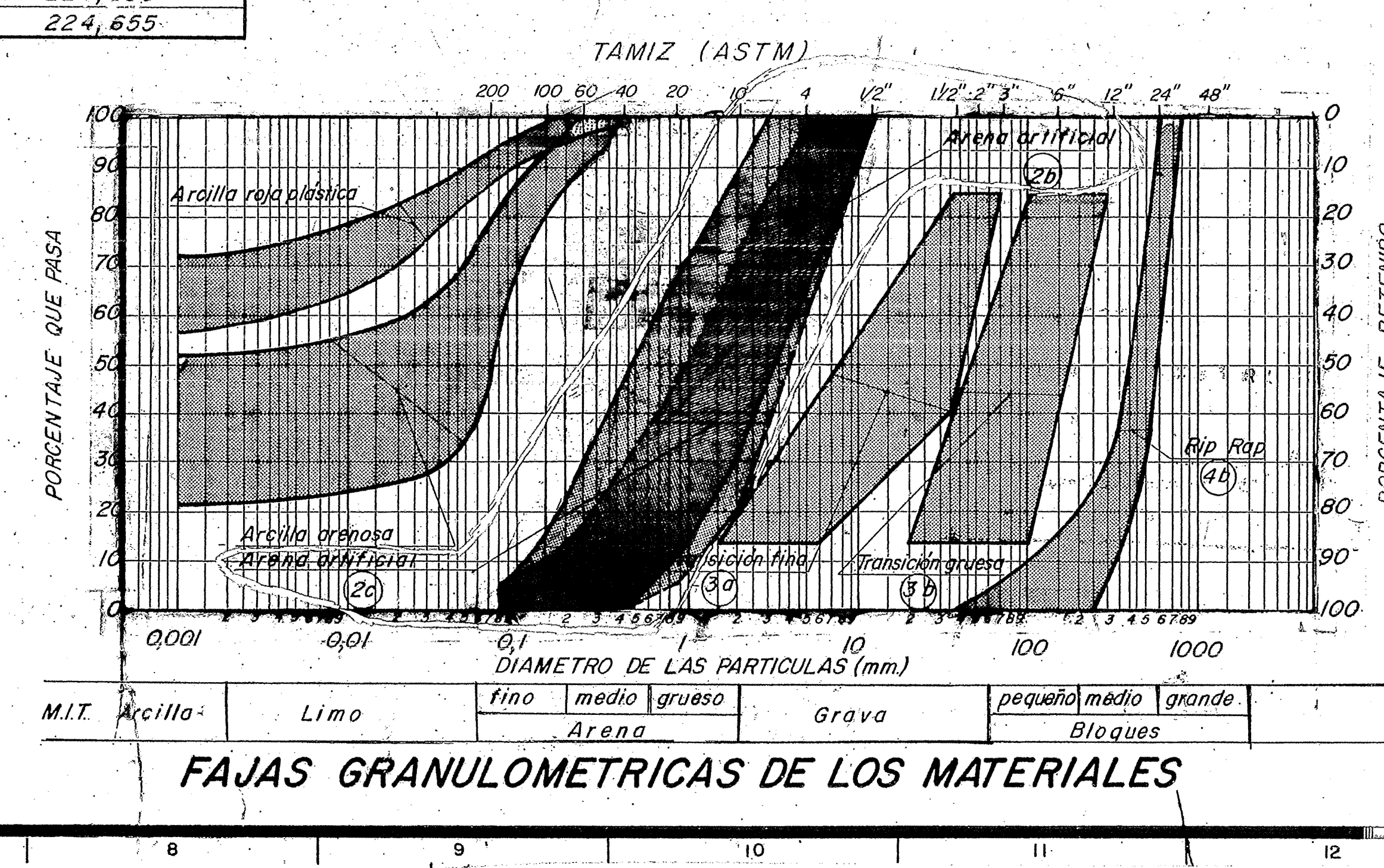


Anexo VII - Instrumentação das seções estudadas. 


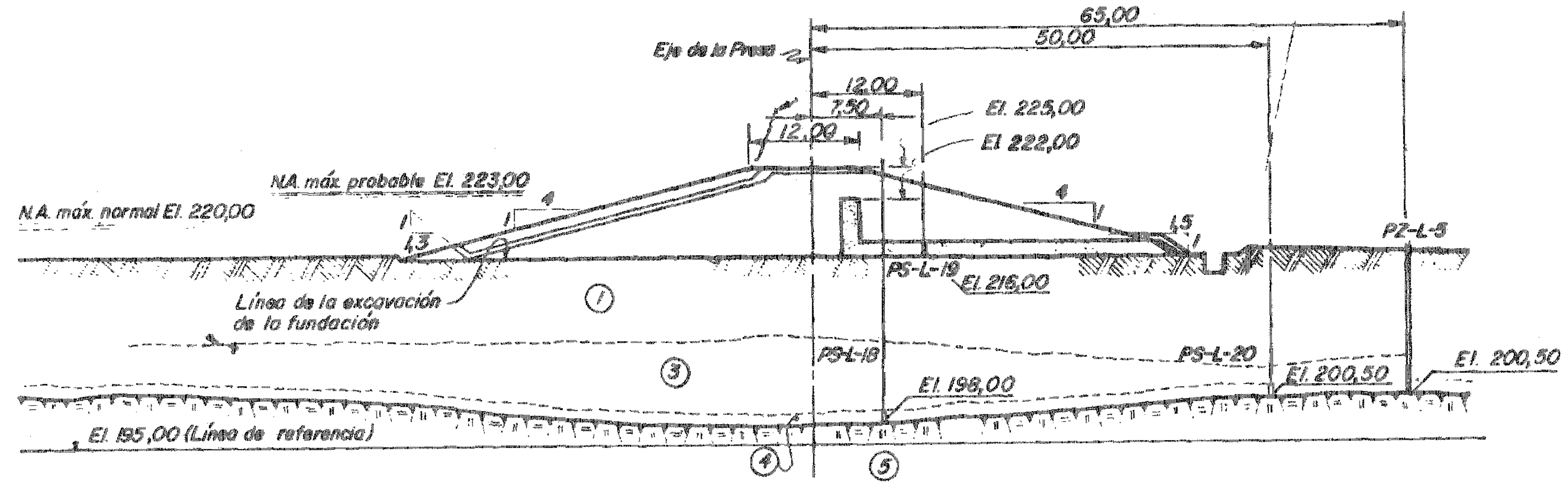

SECCION EST 129450

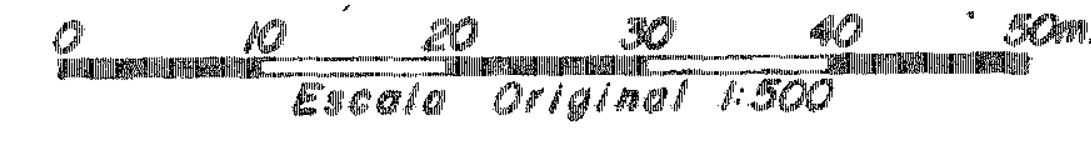

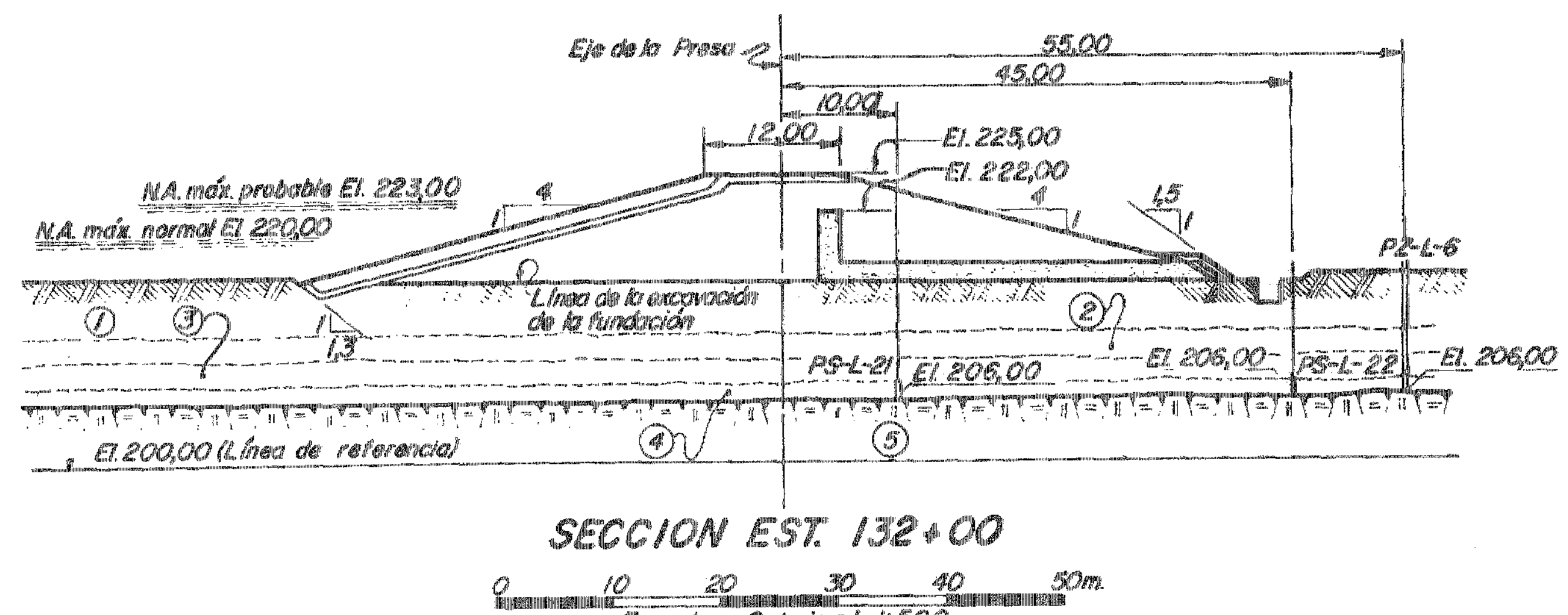

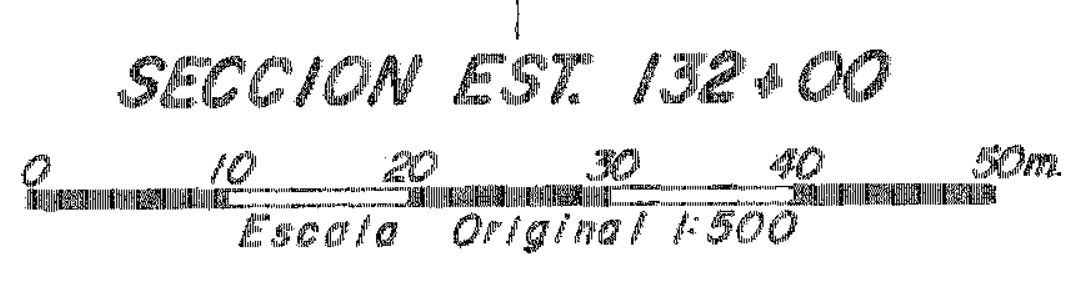

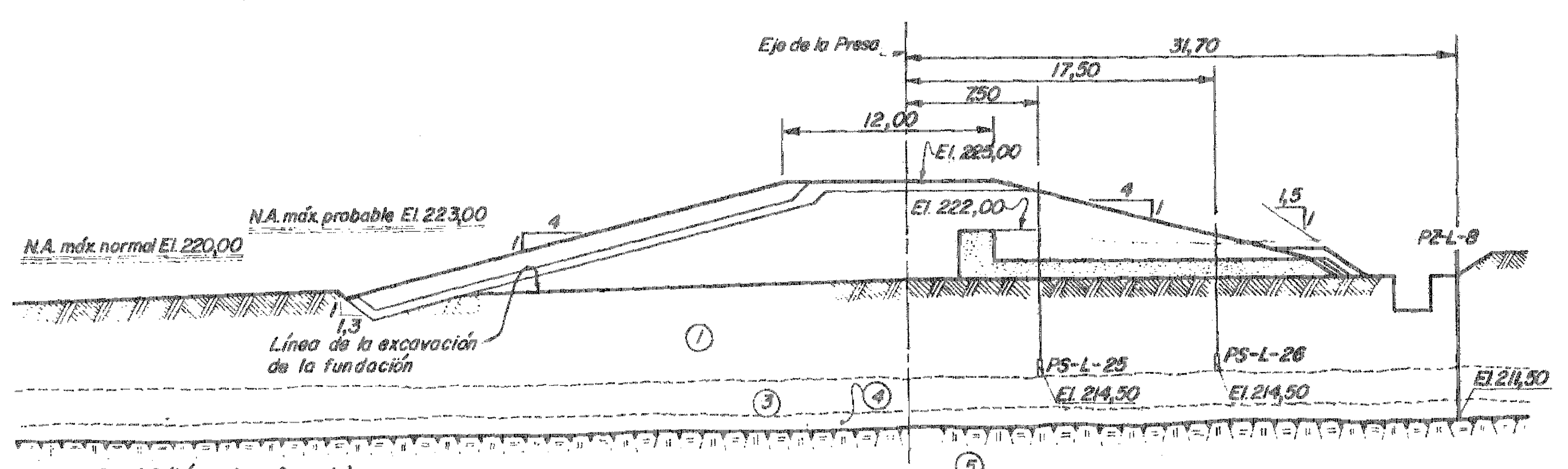

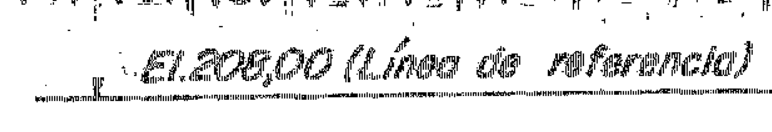

$$
\begin{aligned}
& \text { SECCION EST } 138+50
\end{aligned}
$$

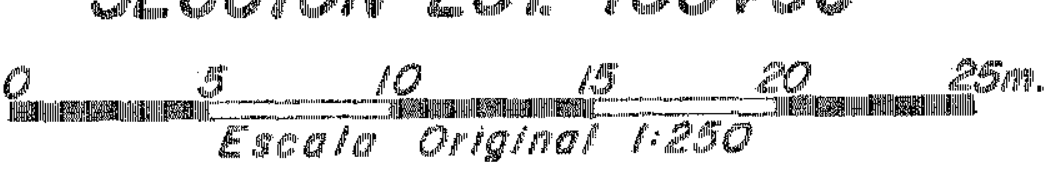

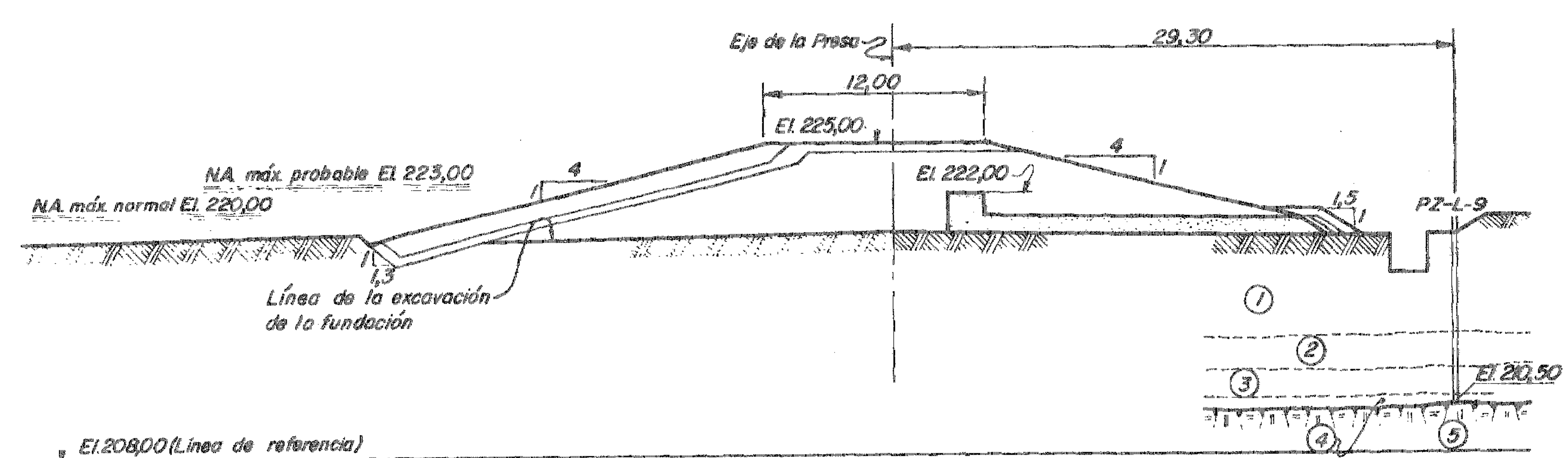

SECCION EST. 140.00

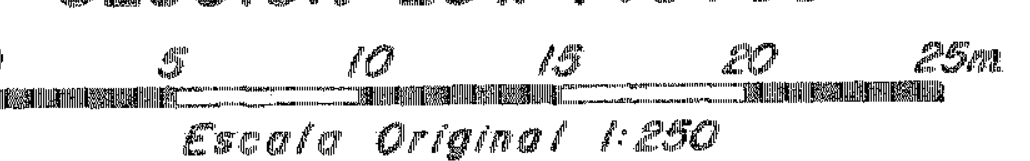

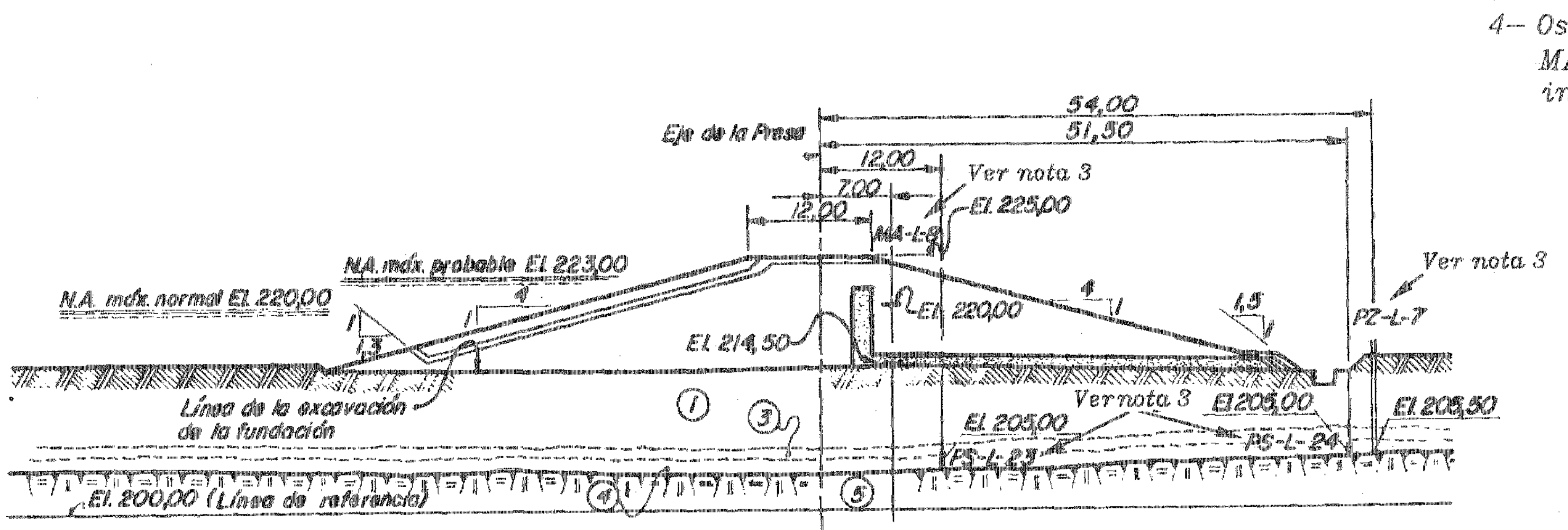

NOTAS

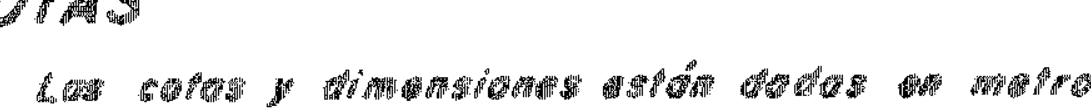

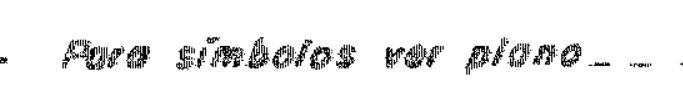

$-4282-D C-4006-5$ piezômetros $P S-L 23, P S L-24$ e o medidor de recolqu Watalados na cota $135+50$ mantendoo mesmo a fastamento

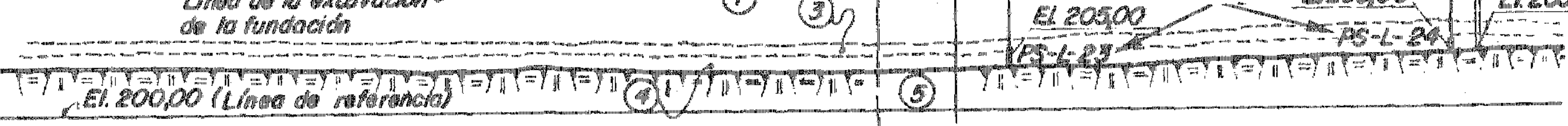

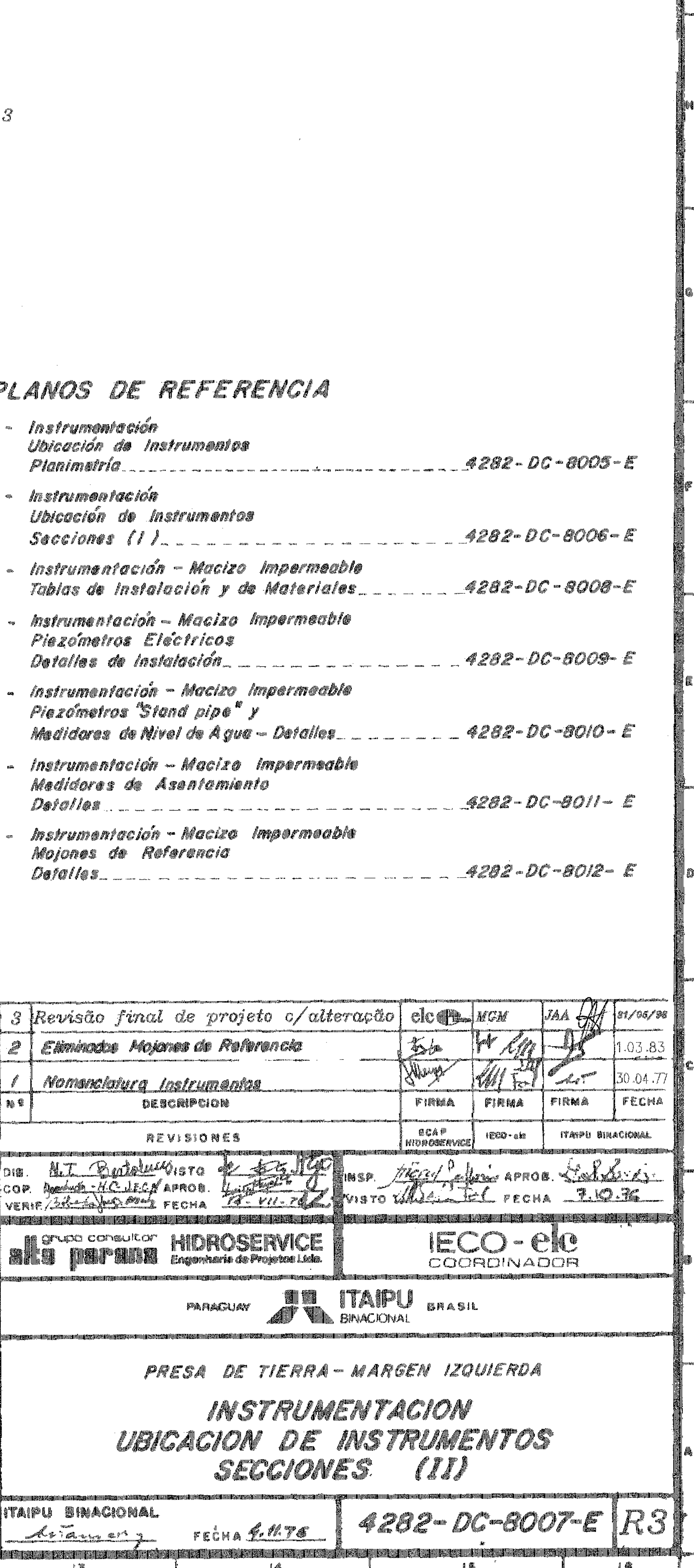

